JOÃO PEDRO BARROSO DO NASCIMENTO

ANOtAÇões SobRe MEDIDAS DEFENSIVAS À TOMADA DE CONTROLE

Dissertação de Mestrado

Orientador: Prof. Dr. Mauro Rodrigues Penteado

Faculdade de Direito da Universidade de São Paulo São Paulo - 2010 
JOÃO PEDRO BARROSO DO NASCIMENTO

\title{
ANOtAÇões Sobre MedidAs Defensivas À TOMAdA DE CONTROLE
}

\begin{abstract}
Dissertação de Mestrado apresentada ao Departamento de Direito Comercial da Faculdade de Direito da Universidade de São Paulo como requisito parcial para a obtenção do grau de mestre, sob a orientação do Professor Associado Dr. Mauro Rodrigues Penteado.
\end{abstract}

Faculdade de Direito

Universidade de São Paulo

São Paulo - 2010 


\section{RESUMO}

As medidas defensivas contra tomadas de controle constituem o núcleo de estudo desta dissertação. São instrumentos jurídicos adotados principalmente por companhias abertas com dispersão acionária, visando à proteção contra uma eventual tentativa de tomada de controle.

O assunto é de especial interesse no atual momento do mercado de capitais brasileiro, que vem apresentando significativo desenvolvimento nos últimos anos e propiciando meios para a proliferação no Brasil de companhias abertas com dispersão acionária.

O estudo do tema é feito concomitantemente à crescente utilização no Brasil de proteções contra tomadas de controle, inclusive por companhias não dotadas de dispersão acionária. Algumas medidas defensivas são inspiradas na experiência prática de outros países e vêm sendo transplantadas para o Brasil sem a adequada harmonização às características do nosso regime jurídico.

Este trabalho analisa os efeitos da utilização de medidas defensivas e, na medida do possível, a admissibilidade da adoção de determinadas defesas no Brasil. São também abordados os balizamentos para a postura da administração de companhias diante de tentativas de tomada de controle.

São estudados os padrões de tratamento do tema nos principais modelos existentes na experiência internacional, a fim de fornecer subsídios para a criação de uma identidade brasileira no tratamento das defesas contra tentativas de tomada de controle.

Palavras-Chave: medidas defensivas; tomada de controle; oferta pública de aquisição; poder de controle; deveres da administração; shark repellants; pílula de veneno, poison pill; cláusula de proteção à dispersão acionária; espécies de medidas defensivas; direito societário comparado. 


\begin{abstract}
The defensive anti-takeover measures constitute the core area of study in this dissertation. These are legal devices adopted mainly by publicly-held companies with widespread ownership dispersion, aiming at protection against an eventual takeover attempt.

The subject is of special interest at the current moment of the Brazilian capital markets, which have shown significant development in the recent years, providing means for the proliferation in Brazil of publicly-held companies with widespread ownership dispersion.
\end{abstract}

The study of the issue is done concomitantly with the increase of utilization in Brazil of anti-takeover protections, including by companies without widespread ownership dispersion. Some defensive measures are inspired by the practical experience of other countries, being transplanted to Brazil without the proper harmonization with the characteristics of our own legal system.

This work analyzes the effects of the utilization of defensive measures and, to the extent possible, the admissibility of adoption of certain defenses in Brazil. The boundaries for the behavior of the management of companies under takeover attempts are also approached.

The patterns for the treatment of this issue in the main existing models in foreign experience are studied, so as to provide subsidies to the creation of a Brazilian identity in the treatment of the defenses against takeover attempts.

KEYWORDS: defensive measures; takeover; tender offer; controlling power; management duties; shark repellants; poison pill; protection to diluted ownership clauses; kinds of defensive measures; comparative corporate law. 


\section{Abreviaturas}

BM\&F-Bovespa

City Code

CE

CMVM

$\mathrm{CNV}$

COB

Código Civil

Código Penal

Consob

CVM

Diretiva n ${ }^{\circ}$ 2004/25/CE

EUA

Lei $n^{\circ}$ 6.404/76

Lei ${ }^{\circ} 8.666 / 93$

Lei $n^{\circ} 8.987 / 95$

Lei $n^{0}$ 9.784/99

Lei $\mathrm{n}^{\circ}$ 10.303/01

Ley de Sociedades

Comerciales

RDM

$\mathrm{RDB}$

$\mathrm{RDC}$

$\mathrm{RF}$

ROA

RT

Instrução CVM n ${ }^{0}$ 10/80

Instrução CVM n 319/99

Instrução CVM n ${ }^{\circ}$ 323/00

Instrução CVM n ${ }^{\circ}$ 358/02

Instrução CVM n ${ }^{\circ}$ 361/02

Instrução CVM n ${ }^{\circ}$ 400/03

SEC

TUF

UE

WpÜG
Bolsa de Valores, Mercadorias e Futuros S.A.

City Code on Takeovers and Mergers (Inglaterra)

Comunidade Econômica Europeia

Comissão do Mercado de Valores Mobiliários (Portugal)

Comisión Nacional de Valores (Argentina)

Commission des Opérations de Bourse (França)

Lei ${ }^{\circ}$ 10.406, de 10 de janeiro de 2002

Decreto-Lei $\mathrm{n}^{\circ} 2.848$, de 7 de dezembro de 1940

Commissione Nazionale per le Società e la Borsa (Itália)

Comissão de Valores Mobiliários (Brasil)

Diretiva $\mathrm{n}^{\circ}$ 25, de 21 de Abril de 2004, do Parlamento

Europeu e do Conselho da UE

Estados Unidos da América

Lei ${ }^{\circ}$ 6.404, de 15 de dezembro de 1976

Lei ${ }^{\circ} 8.666$, de 21 de junho de 1993

Lei $n^{\circ}$ 8.987, de 13 de fevereiro de 1995

Lei $n^{\circ} 9.784$, de 29 de janeiro de 1999

Lei $\mathrm{n}^{\circ}$ 10.303, de 31 de outubro de 2001

Ley $n^{\circ} 19.550$ (Argentina)

Revista de Direito Mercantil, Industrial, Econômico e Financeiro

Revista de Direito Bancário e do Mercado de Capitais

Revista de Direito do Consumidor

Revista Forense

Revista da Ordem dos Advogados (Portugal)

Revista dos Tribunais

Instrução CVM n ${ }^{\circ}$ 10, de 14 de fevereiro de 1980

Instrução CVM n ${ }^{\circ}$ 319, de 3 de dezembro de 1999

Instrução CVM n ${ }^{\circ} 323$, de 14 de janeiro de 2000

Instrução CVM no 358, de 3 de janeiro de 2002

Instrução CVM n ${ }^{0}$ 361, de 5 de março de 2002

Instrução CVM n 400, de 29 de dezembro de 2003

Securities and Exchange Commission (EUA)

Decreto Legislativo $\mathrm{n}^{0}$ 58/1998 (Testo Unico Finanziario)

(Itália)

União Europeia

Wertpapierwerbs und Übernahmegesetz (Alemanha) 


\section{ANOTAÇões SOBRE MEDIDAs DEFENSIVAs À \\ TOMADA DE CONTROLE}

I. INTRODUCÃO

4

II. PODER DE CONTROLE

15

2.1 CONSIDERAÇÕES PRELIMINARES

2.2 CONCEITO

2.3 Tipologia do Poder Controle 21

2.3.1 CONTROLE INTERNO 22

2.3.1.1 CONTROLE QuASE TOTALitáRIO 23

2.3.1.2 CONTROLE MAJORITÁRIO 24

2.3.1.3 CONTROLE MINORITÁRIO 25

2.3.1.4 CONTROLE GERENCIAL 26

2.3.2 CONTROLE EXTERNO 27

2.4 CONTROLE CONCENTRADO VS. CONTROLE DIFUSO 29

2.5 A REALIDADE BRASILEIRA 32

III. AQUISIČÃO OU OBTENÇÃO DO PODER DE CONTROLE

3.1 CLASSIFICAÇÃO 38

3.1.1 VOLUNTÁRIA OU INVOLUNTÁRIA 38

3.1.2 ORIGINÁRIA OU DERIVADA 40

3.1.3 DECORRENTE DE OPERAÇÃO ISOLADA OU DE OPERAÇÕES CONJUNTAS 43

3.1.4 AMIGÁVEL OU HOSTIL 43

3.2 MÉTOdos DE AQUisiçÃo OU OBTENÇÃO DO PODER DE CONTROLE 45

3.2.1 COMPRA E VENDA NEgOCIADA DE AÇÕES DO CONTROLE

3.2.2 ESCALADA ACIONÁRIA 46

3.2.3 CESSÃO DO CONTROLE EXTERNO 51

3.2.4 SUBSCRIÇÃO DE AÇÕES 52

3.2.5 CONVENÇÕES DE VOTO 53

3.2.6 OFERTA PÚBliCA DE AQUisição de CONTROLE 56

IV. OFERTA PÚBLICA DE AQUISIČ̃̃O DE CONTROLE

4.1 CONCEITO E GENERALIDADES

4.2 HISTÓRICO 61

$\begin{array}{lll}4.3 & \text { NATUREZA JURÍDICA } & 70\end{array}$

4.4 LEGISLAÇão APLICÁVEL

4.5 APLICAÇÃO E EFEITOS

4.6 VIABILIZAÇÃO FINANCEIRA 85

4.6.1 RECURSOS PRÓPRIOS 85 
4.6.2 RECURSOS DE TERCEIROS 86

4.6.2.1 LBO - LEVERAGED BUYOUT $\quad 87$

4.6.2.2 MBO - MANAGEMENT BUYOUT $\quad 89$

4.7 ESCOLHA DA COMPANHIA-ALVO 91

4.8 PREÇO DA OFERTA 94

V. MEDIDAS DEFENSIVAS $\quad \mathbf{9 7}$

5.1 Tipologia das MEdidas DefEnsivas 102

5.1.1 PREVENTIVAS E POSTERIORES 102

5.1.1.1 MEdIDAS DEFENSIVAS PREVENTIVAS 103

5.1.1.2 MEDIDAS DEFENSIVAS POSTERIORES 104

5.1.2 ESTATUTÁRIAS, CONTRATUAIS E INSTITUCIONAIS 105

5.1.2.1 MEDIDAS DEFENSIVAS ESTATUTÁRIAS 106

5.1.2.2 MEDIDAS DEFENSIVAS CONTRATUAIS 106

5.1.2.3 MEDIDAS DEFENSIVAS INSTITUCIONAIS 108

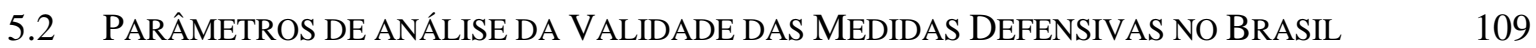

$\underline{\text { VI. ESPÉCIES DE MEDIDAS DEFENSIVAS }} \quad 118$

6.1 PÍlula de VENENO (POISON PILL) 118

$\begin{array}{lll}6.1 .1 & \text { FLIP IN } & 126\end{array}$

6.1.1.1 BÔNUS DE SUBSCRIÇÃO 127

6.1.1.2 PLANO DE OPÇÃO DE COMPRA DE AÇÕES 130

6.1.2 FLIP OVER 132

6.2 ClÁUSUlas de PROTEÇão À DisPersão ACIONÁRIA 134

6.3 LiMITAÇÃO AO NÚMERO DE VOTOS 146

6.4 DELIBERAÇÕES SUJEITAS A QUORUM DE “SUPER-MAIORIA” QUALIFICADA 148

6.5 CONSELHO DE AdMINISTRAÇÃO ESCALONADO (STAGGERED BOARD) 150

6.6 CAVALEIRO BRANCO (WHITE KNIGHT) 153

6.7 ESCUDEIRO BRANCO (WHITE SQUIRE) 156

6.8 JÓIA DA COROA (CROWN JEWEL) 157

6.9 GREENMAIL 161

6.10 DeFESA PAC-MAN 163

6.11 PÁRA-QUEDAS DOURADO (GOLDEN PARACHUTE) 164

6.12 PEOPLE PILL 167

6.13 SHOW STOPPER OU SAFE HARBOUR 167

6.14 MACARONI DEFENSE 169

6.15 VENCIMENTO ANTECIPADO DE EMPRÉSTIMOS E DE CONTRATOS RELEVANTES 170

6.16 STANDSTILl AGREEMENTS 171

6.17 “APENAS DIGA NÃO” (JUST SAY NO) 172 
6.18 BATALHA JUDICIAL E/OU ARBITRAL

VII. EFEITOS DAS MEDIDAS DEFENSIVAS

7.1 ESTABILIZAÇÃO DA DISPERSÃO ACIONÁRIA

7.2 EFEITO NO PREÇO DE COMPRA 180

7.3 EFEITO DisCIPLINAR EM RELAÇÃO À ADMINISTRAÇÃO 182

7.4 DESESTÍMULO AO INVESTIMENTO 183

7.5 ENVOLVIMENTO DA AdMINISTRAÇão NA NEGOCIAÇÃO 184

\section{PODERES E DEVERES DA ADMINISTRAÇÃO EM RELAC̄̃̃O ÀS MEDIDAS} DEFENSIVAS

8.1 Modelos DE CONDUTA E PAdRÕES DE REVISÃO DA ATUAÇÃO DA AdMINISTRAÇÃO 186

8.2 CASOS PARADIGMÁTICOS NOS ESTADOS UNIDOS DA AMÉRICA 189

8.2.1 SMITH V. VAN GORKOM 190

8.2.2 Unocal CorP. V. Mesa PETROLEum Co. 192

8.2.3 REVLON V. MACANDREWS AND FORBES HOLDINGS, INC. 195

8.2.4 PARAMOUNT COMMUNICATIONS, INC. V. TIME, INC 199

8.2.5 PARAMOUNT COMMUNICATIONS, INC. V. QVC NETWORK, INC 201

8.2.6 PRECEDENTES AOS CASOS PARADIGMÁtICOS 203

8.3 LIMITES À ATUAÇÃO DA ADMINISTRAÇ̃̃O 204

8.3.1 NEUTRALIDADE DO CONSELHO DE ADMINISTRAÇÃO (BOARD NEUTRALITY) 205

8.3.2 RESTRIÇÕES Às MEDIDAS DEFENSIVAS (BREAK-THROUGH RULES) 207

8.4 DEVERES FIDUCIÁRIOS (FIDUCIARY DUTIES) 208

8.5 REgRA DO JULGAMENTO DO NEGÓCiO (BUSINESS JUdGMENT RULE) 213

8.6 DEVERES DA ADMINISTRAÇÃO NA LEI No 6.404/76 215

8.6.1 DEVER DE DILIGÊNCIA 216

8.6.2 Finalidades DAS ATRIBUiçÕES E DESVIO DE PODER 218

8.6.3 DEVER DE LEALDADE 221

8.6.4 CONFLITO DE INTERESSES E TUTELA DO INTERESSE SOCIAL 223

8.6.5 DEVER DE INFORMAR 224

$\underline{\text { IX. LINEAMENTOS DE COMPARAÇÃO JURÍDICA }} 228$

$\begin{array}{lll}9.1 & \text { EUROPA } & 229\end{array}$

9.1.1 INGLATERRA 234

9.1.2 EUROPA CONTINENTAL 238

9.1.2.1 ALEMANHA 239

$\begin{array}{lll}\text { 9.1.2.2 PORTUGAL } & 241\end{array}$

9.1.2.3 ITÁLIA 243 
9.1.2.4 FRANÇA

9.2 Estados Unidos DA AMÉRICA 246

$\begin{array}{lll}9.3 & \text { ARgENTINA } & 249\end{array}$

X. CONCLUSÃO $\quad 252$

XI. BIBLIOGRAFIA 
I.

\section{INTRODUÇÃO}

O século XX é reconhecido como o período de formação das grandes companhias e da intensificação da organização de empresas mediante mecanismos jurídicos capazes de propiciar negócios estruturados em grande escala.

A consolidação do modelo econômico capitalista, especialmente após a $2^{\mathrm{a}}$ Guerra Mundial, a evolução dos mercados de capitais internacionais, a modernização das economias de mercado e, até mesmo, os avanços tecnológicos que encurtaram distâncias e propiciaram mecanismos eficientes para que agentes de mercado, localizados em regiões diferentes, praticassem negócios entre si, são alguns dos elementos que podem ser apontados como responsáveis pela modificação da perspectiva clássica em relação às sociedades anônimas ${ }^{1}$.

Nesse contexto econômico com reconhecidos efeitos jurídicos, especialmente no direito comercial e, mais precisamente, no direito societário, as companhias passam a requerer investimentos e aportes de recursos em volumes cada vez mais expressivos. Dá-se o processo de concentração empresarial ${ }^{2}$, com número crescente de operações de fusão,

\footnotetext{
${ }^{1}$ Relatos históricos informam que, a partir da década de 1950, com o término da $2^{\text {a }}$ Guerra Mundial e fortalecimento da economia nos EUA e na Inglaterra, os investidores financeiros, em geral, perceberam que havia certos riscos inerentes a determinados produtos e/ou setores de atuação na economia que poderiam ser reduzidos com a diversificação dos setores nos quais os investimentos são realizados. É neste contexto que se fortalece ainda mais o interesse pelo mercado de capitais e a dinamização da dispersão das estruturas de capital nas companhias abertas de países em elevado estágio de evolução do modelo capitalista, especialmente nos EUA e na Inglaterra (MOORE, Andrew G.T. The Birth of Unocal: A Brief History. Delaware Journal of Coporate Law. v. 31, n. 3, pp. 865-886, 2006. Disponível em: $<$ http://ssrn.com/abstract=946018 $>$. Acesso em: 12.12.2009).

2 Sobre o tema, lecionam Alfredo Lamy Filho e José Luiz Bulhões Pedreira: "[E]sse processo de concentração foi naturalmente induzido por dois objetivos visados pelas organizações produtivas: diminuir a instabilidade a que estão sujeitas as empresas que vendem em mercados altamente competitivos e obter as vantagens propiciadas pela grande dimensão - redução dos custos unitários de produção, integração vertical da produção ou maior poder nos mercados, capacidade para planejar o longo prazo, segurança de financiamento da expansão através de reinvestimento de lucros, capacidade de investir em pesquisa tecnológica e no desenvolvimento de novos produtos, e maior poder nas relações com as comunidades locais e os governos nacionais" (LAMY FILHO, Alfredo; BULHÕES PEDREIRA, José Luiz. Formação e desenvolvimento das sociedades por ações. In: __ . A Lei das S.A. v. 1, pp. 19-102, Rio de Janeiro: Renovar, 1997, p. 62). Reproduzindo e complementando estas ideias, os próprios Alfredo Lamy Filho e José Luiz Bulhões Pedreira expuseram que: “[o] processo de concentração conduziu à formação, nos países mais desenvolvidos, de empresas de grande porte, cujas dimensões, como organizações sociais, somente podem ser comparadas com os Estados nacionais e suas subdivisões” (LAMY FILHO, Alfredo; BULHÕES PEDREIRA, José Luiz. Direito das Companhias. v. 1, Rio de Janeiro: Forense, 2009, p. 784).
} 
incorporação e transferências de controle de companhias ${ }^{3}$. Desse modo, há desenvolvimento e diversificação dos mecanismos de captação de recursos. Neste processo evolutivo, as companhias assumem dimensões cada vez maiores, com a proliferação das macroempresas.

Esses fenômenos econômicos de consequências jurídicas, na maioria dos casos, manifestam-se primeiramente nos países de economia mais desenvolvida, como, por exemplo, nos EUA e na Inglaterra, para apenas em seguida manifestarem-se nos países que, tal como o Brasil, ainda se encontram em processo de desenvolvimento. Por conta desta tendência natural de que determinados eventos ocorridos em países desenvolvidos venham a se manifestar posteriormente nos países em desenvolvimento, há sempre a expectativa de que ocorrências de países de economia mais desenvolvida também se exteriorizem no Brasil.

A concepção estreita de que os acionistas são os proprietários da companhia e os membros dos órgãos de administração são profissionais que atuam simplesmente cumprindo ordens dos "proprietários da companhia” é alterada ${ }^{4}$. Torna-se obrigatória uma mudança de paradigmas, reconhecendo a efetiva separação entre propriedade e gestão ${ }^{5}$, em companhias de dimensões cada vez maiores (macroempresas).

A ideia clássica de que o proprietário da companhia conduz, por si, todos os negócios desta e, quando muito, “delega” determinadas atribuições a administradores que atuarão sob o seu comando, perde coerência ${ }^{6}$. Observam-se a profissionalização dos

\footnotetext{
${ }^{3}$ COMPARATO, Fábio Konder. Aspectos Jurídicos da Macroempresa. São Paulo: RT, 1970, pp. 1-10.

${ }^{4}$ Francisco Müssnich aponta a existência de dois períodos característicos na evolução das companhias. "Num primeiro período, o desenvolvimento da empresa moderna é atribuído e identificado com o empresário que havia sido seu próprio fundador ou geralmente era o acionista controlador e, via de regra, possuía o poder de decisão em todos os assuntos empresariais. Na realidade, o empresário e a empresa confundiam-se, assim como confundiram-se as noções de administração e capital. Num segundo período, caracterizou-se a empresa moderna pelo advento de um novo 'grupo social' constituído dos administradores profissionais. Nesta fase, as funções usualmente atribuídas aos empresários, vão sendo gradativamente transferidas a esta nova 'classe', cuja única função era administrar a empresa, muito embora, na maioria das vezes, nunca tivessem participado da sua criação ou ainda investido capital de risco” (MÜSSNICH, Francisco Antunes Maciel. A utilização desleal de informações privilegiadas - "Insider Trading” - no Brasil e nos Estados Unidos. RDM. São Paulo: Malheiros, n. 34, pp. 31-51, abr./jun. 1979, p. 32).

${ }^{5}$ BERLE, Adolf A.; MEANS, Gardiner C. The modern corporation and private property. 9. ed. New Brunswick / New Jersey: Transaction Publishers, 2007.

${ }^{6}$ Fábio Konder Comparato ensina que "no esquema jurídico tradicional da sociedade anônima, ainda se poderia sustentar que os diretores são meros detentores dos bens sociais, em cumprimento de ordens e instruções dos acionistas. [...] Legisladores e tribunais passaram a reconhecer que os administradores de uma
} 
mecanismos de gestão e a diversificação dos prestadores de capital nas macroempresas, tudo com o objetivo principal de fomentar a grande demanda de recursos destas companhias.

Tornam-se cada vez mais frequentes, especialmente na experiência internacional, companhias em que o poder de controle não está identificado em determinado acionista detentor da maioria do capital social com direito de voto. Isto é, passa a ser relativizada a concepção tradicional de que o poder de controle é exercido apenas por acionista detentor da maioria do capital social votante da companhia.

Aos poucos, tornam-se comuns, também, sobretudo no estrangeiro, as companhias em que as participações acionárias estão pulverizadas, ou seja, intensamente distribuídas entre acionistas, dando origem ao fenômeno da dispersão do capital social e às relações de exercício de poder de controle sobre a companhia ${ }^{7}$.

Surgem explicações econômicas para o fenômeno da dispersão do capital social, à luz dos propósitos de alocação do risco do empreendimento entre número cada vez maior de prestadores de capital ${ }^{8}$. Os empreendedores passam, cada vez mais, a buscar mecanismos para não concentrarem em si todo o risco do empreendimento a ser desenvolvido, buscando diversificá-lo entre número maior de participantes no negócio ${ }^{9}$,

companhia exercem poderes próprios do órgão de direção da sociedade e não funções delegadas da assembléia geral, e nessa condição não tem que se submeter a ordens ou injunções dos acionistas no que entende com as tarefas normais de administração. [...] Tampouco os acionistas podem ser considerados proprietários dos bens sociais. [...] O acionista nada mais é do que proprietário de ações da sociedade, e justamente por isso não pode ser proprietário dos bens sociais” (COMPARATO, Fábio Konder. Aspectos Jurídicos da Macroempresa. São Paulo: RT, 1970, pp. 77-78).

7 “Um dos efeitos do aumento de escala da companhia é a dispersão da propriedade das ações: quanto maior a dimensão da companhia, mais difícil é cada acionista manter sua porcentagem de participação nos aumentos de capital necessários ao financiamento da expansão da empresa; as operações de fusão e incorporação implicam redução da participação percentual dos acionistas das companhias envolvidas; e a crescente pulverização das ações da grande companhia cria o fenômeno referido como separação entre o poder de controle e a propriedade das ações [...]” (LAMY FILHO, Alfredo; BULHÕES PEDREIRA, José Luiz. Direito das Companhias. v. 1, Rio de Janeiro: Forense, 2009, pp. 784-785).

${ }^{8} \mathrm{O}$ aumento do número de investidores de capital reduz a exposição do risco ao qual determinado empreendedor se submeteria se investisse isoladamente o capital necessário ao referido empreendimento.

${ }^{9}$ Yakov Amihud e Baruch Lev ensinam que "the motive of risk reduction through diversification appeared at first to provide a natural explanation for the conglomerate merger phenomenon” (AMIHUD, Yakov; LEV, Baruch. Risk Reduction as a Managerial Motive for Conglomerate Mergers. In: ROMANO, Roberta [coord.]. Foundations of Corporate Law. 2. re-imp. Nova York: Foundation Press, 2004, p. 232). 
com a adoção de modelos diferentes de captação dos recursos a serem utilizados em sua atividade ${ }^{10}$.

Em decorrência da proliferação de macroempresas com grande dispersão acionária, tornam-se frequentes casos de ruptura entre o poder empresarial e o risco. A dispersão acionária, em algumas companhias, dá origem a situações em que o poder de controle é exercido, até mesmo, por acionistas detentores de ações representativas de uma pequena participação acionária (controle minoritário), por administradores da companhia (controle gerencial) e, em alguns casos, por agentes externos capazes de exercer influência dominante sobre a companhia (controle externo).

Observa-se o desenvolvimento de mecanismos, cada vez mais eficientes, para que detentores de participações acionárias minoritárias possuam maior ingerência nas atividades sociais, a fim de se consolidarem como relevantes agentes econômicos em tais companhias e, quiçá, acionistas controladores.

Na medida em que se dá a dispersão acionária, as companhias tornam-se mais suscetíveis a movimentos que visem à tomada de seu controle acionário, propiciando mecanismos para que terceiros interessados na aquisição do controle o façam mediante operações realizadas em bolsa de valores e/ou mediante oferta pública aos seus acionistas.

Nos países que possuem mercado de capitais altamente desenvolvido, em especial, nos EUA e na Inglaterra, as companhias com dispersão acionária tornam-se alvo frequente de tentativas de tomada de controle, mediante a realização de ofertas públicas de aquisição de controle, usualmente referidas como tender offers nos EUA e takeover bids na Inglaterra. Em inúmeros casos, tais ofertas são estruturadas e realizadas de forma hostil, sem o envolvimento dos membros da administração da companhia-alvo e sem negociações com determinados acionistas e/ou grupos de acionistas relevantes de tal companhia-alvo.

Como será examinado adiante, a hostilidade das ofertas públicas destinadas à tomada de controle refere-se à administração da companhia-alvo e/ou a determinados

\footnotetext{
${ }^{10}$ São realizadas reflexões econômicas sobre os efeitos dos mecanismos disponíveis para a captação de recursos por companhias. De um lado, pondera-se sobre as consequências em se admitir um novo investidor de capital com participação societária na companhia (equity) e, de outro lado, reflete-se sobre os efeitos de assumir endividamento (debt) para obter os recursos necessários para a companhia.
} 
acionistas e/ou grupo de acionistas relevantes desta última, e não aos acionistas cujas ações se encontram dispersas em bolsa de valores. A oferta pública revela-se hostil justamente por afrontar eventual poder de controle de acionistas e/ou grupo de acionistas relevantes da companhia-alvo e, em relação à administração da companhia, reputar-se-á como não amigável por ser realizada à revelia desta última, que, em regra, não participará das negociações visando à tomada de controle.

Consequentemente, diante da ameaça iminente de tomada do controle, desenvolvem-se na experiência internacional, especialmente no EUA, mecanismos para a proteção das companhias em relação a tais tentativas. Casos paradigmáticos de tomadas de controle hostis são submetidos à apreciação do Poder Judiciário nos países em que o mercado de capitais estrutura-se com companhias abertas dotadas de dispersão acionária. Em alguns destes casos submetidos ao Poder Judiciário, há companhias-alvo que adotam medidas defensivas visando a impedir a tomada de controle. A dinâmica evolutiva natural, decorrente do uso reiterado de tais mecanismos de defesa, propicia meios para o desenvolvimento de enorme diversidade de métodos defensivos nos EUA. Por outro lado, na Inglaterra, a postura adotada revela-se diametralmente oposta, tendente a não admitir a adoção de defesas, com base em um sistema jurídico baseado em normas de auto-regulação do City Code ${ }^{11}$.

No Brasil, o início do século XXI vem se revelando como período de intenso desenvolvimento do mercado de capitais. A proliferação das ofertas públicas iniciais de ações, também referidas como “OPIs” ou “IPOs”, em referência à expressão em inglês Initial Public Offering (IPO), trouxe para a realidade pátria algumas reflexões jurídicas até então praticamente inaplicáveis ${ }^{12}$.

\footnotetext{
${ }^{11}$ O City Code disciplina os takeovers bids no Reino Unido pela via corporativa, sendo elaborado por agentes do mercado de capitais da City de Londres. Trata-se de sistema de auto-regulação de adesão voluntária. Para maiores informações, referir-se a COMPARATO, Fábio Konder; SALOMÃO FILHO, Calixto. O Poder de Controle na Sociedade Anônima. 4. ed. Rio de Janeiro: Forense, 2005, p. 241. O City Code e o Reino Unido serão abordados nos Lineamentos de Comparação Jurídica constantes do Capítulo IX deste trabalho.

${ }^{12}$ Com base nos dados oficiais divulgados pela BM\&F-Bovespa, 110 (cento e dez) companhias realizaram aberturas de capital no período compreendido entre o início de 2004 e o final de 2008, tendo sido listadas perante a BM\&F-Bovespa, realizando distribuições públicas de valores mobiliários de sua emissão. (BM\&FBOVESPA. Empresas Para Empresas: IPOs Recentes. Disponível em: $<$ http://www.bovespa.com.br/Empresas/InstInfoEmpresas/AberturaIPOsRecentes.asp?tit=27>. Acesso em 12.12.2009).
} 
Especialmente no período compreendido entre janeiro de 2004 e setembro de $2008^{13}$, o mercado de valores mobiliários brasileiro apresentou elevadas taxas de crescimento, com a realização de grande quantidade de ofertas públicas iniciais, que captaram volume expressivo de recursos ${ }^{14}$.

O crescimento do mercado acionário brasileiro torna efetiva a utilização de distribuições públicas de ações como mecanismo eficiente para captação de recursos para as companhias ${ }^{15}$.

O fortalecimento recente do mercado de capitais brasileiro inseriu-se em contexto de prosperidade econômica global e abundância de investimentos em países emergentes, mas, como pondera a doutrina pátria ${ }^{16}$, também deve ser creditado a uma série de iniciativas coordenadas. Dentre elas, destacam-se o esforço empreendido nas reformas das Leis $\mathrm{n}^{\mathrm{o}}$ 6.404/76 e 6.385/76 para aprimorar e fortalecer os direitos dos acionistas minoritários, e a criação, pela BM\&F-Bovespa, de segmentos especiais de negociação de ações, de adesão voluntária, reservados para companhias que adotem práticas diferenciadas

\footnotetext{
${ }^{13}$ Durante o último trimestre de 2008 e primeiro semestre de 2009 a crise econômica mundial impactou em redução do número de aberturas de capital e ofertas públicas de distribuição de valores mobiliários realizadas. Entretanto, o segundo semestre de 2009 vem apresentando retomada do processo de crescimento, mas ainda sem o mesmo grau de aceleração observado entre janeiro de 2004 e setembro de 2008.

14 “O Brasil foi, em 2007, o $5^{\circ}$ mercado em volume financeiro absoluto de ofertas de ações, em termos mundiais, atrás apenas dos volumes ofertados em duas das mais importantes bolsas do mundo - Nova York e Londres, e de dois mercados chineses - Hong Kong e Xangai (segundo dados compilados pela World Federation of Exchanges - WFE)” (SANTANA, Maria Helena dos Santos Fernandes de; GUIMARÃES, Juliana Paiva. Mercado de valores mobiliários: evolução recente e tendências. RDB. São Paulo: RT, n. 41, pp. 56-64, jul./set. 2008, p. 60).

${ }^{15}$ De acordo com os números oficiais divulgados pela BM\&F-Bovespa, as distribuições de valores mobiliários realizadas no período compreendido entre o início de 2004 e o final de 2008 propiciaram a captação do expressivo volume total de aproximadamente R\$ 88.456.000.000,00 (oitenta e oito bilhões, quatrocentos e cinquenta e seis milhões de reais). (BM\&F-BOVESPA. Empresas Para Empresas: IPOs Recentes. Disponível em: <http://www.bovespa.com.br/Empresas/InstInfoEmpresas/AberturaIPOsRecentes.asp?tit=27>. Acesso em 12.12.2009).

${ }^{16}$ Neste sentido, destacamos especialmente: (i) MUNHOZ, Eduardo Secchi. Desafios do direito societário brasileiro na disciplina da companhia aberta: avaliação dos sistemas de controle diluído e concentrado. In: CASTRO, Rodrigo R. Monteiro; ARAGÃO, Leandro Santos de (coord.). Direito Societário: Desafios Atuais. São Paulo: Quartier Latin, 2009, pp. 119-155; e (ii) AZEVEDO, Luis André Negrelli de Moura. A oferta pública para aquisição de controle sob a perspectiva da companhia aberta ofertante. In: CASTRO, Rodrigo R. Monteiro; ARAGÃO, Leandro Santos de (coord.), op. cit., pp. 74-114.
} 
de governança corporativa ${ }^{17}$, com a gradual e crescente adoção de tais práticas diferenciadas pelas companhias abertas brasileiras.

Armínio Fraga Neto, ex-presidente do Banco Central do Brasil, também aponta outros fatores, de ordem econômica, como elementos de contribuição ao crescimento do mercado de capitais brasileiro, com destaque à “superação da crise de confiança de 2002, a retomada de um processo de alta nas principais bolsas de valores do mundo, especialmente as emergentes, assim como a queda na taxa de juros doméstica contribuíram para uma extraordinária decolagem da nossa bolsa” ${ }^{18}$. E arremata relacionando fatores que se destacaram como propulsores deste desenvolvimento:

em primeiro lugar, a queda da inflação e das taxas de juros a partir do Plano Real em 1994 e da adoção do tripé de metas para a inflação, responsabilidade fiscal e taxa de câmbio flutuante a partir do início de 1999. Mas, recentemente, a consolidação deste modelo levou ao grau padrão de investimento (investment grade) por duas das principais agências classificadoras [de risco de investimento] ${ }^{19}$.

${ }^{17}$ O emprego da expressão “governança corporativa” é severamente criticado pela doutrina. Erasmo Valladão Azevedo e Novaes França e Mauro Moisés Kertzer sustentam que a expressão "governança corporativa” não é tradução adequada para corporate governance, propondo que tal expressão estaria traduzida de forma mais adequada para o nosso vernáculo pela expressão "governação compartilhada da companhia” ou mesmo "governo das sociedades”, tal como este conceito é utilizado em Portugal (HOPT, Klaus J. Deveres legais e conduta ética de membros do conselho de administração e de profissionais. Tradução de Erasmo Valladão A. e N. França e Mauro Moisés Kertzer. RDM. São Paulo: Malheiros, n. 144, pp. 107-119, out./dez. 2006, p. 117). Arnold Wald também critica a utilização do termo "governança corporativa”, por tratar-se "de um anglicismo condenável, não só por respeito à língua nacional como também pela associação de ideia que pode acarretar. Na língua portuguesa, corporação tem o sentido de associação profissional, sendo inclusive uma reminiscência medieval”. E conclui ser “mais adequado usar a expressão 'governo das empresas', que é corrente nos países de língua latina, nos quais a corporação não se confunde com a sociedade anônima (WALD, Arnoldo. O governo das empresas. RDB. São Paulo: RT, n. 15, jan./abr. 2002, p. 53). Entretanto, com a devida vênia, neste trabalho, quando fizermos referência aos Regulamentos do Novo Mercado, Nível 1 e Nível 2 da BM\&F-Bovespa, licenciar-mos-emos para utilizar a expressão “governança corporativa”, ainda que eivada de imprecisão conceitual, a fim de seguir a terminologia adotada pela BM\&F-Bovespa.

${ }^{18}$ FRAGA NETO, Armínio. O mercado de capitais como alavanca do desenvolvimento no Brasil. RDB. São Paulo: RT, n. 41, pp. 39-41, jul./set. 2008, p. 40.

${ }^{19}$ Ibid., p. 40. 
Nesse contexto, são cada vez mais comuns as companhias brasileiras em que a estrutura do capital social está dispersa ${ }^{20}$, seguindo entre nós, ainda timidamente, a experiência internacional da dispersão do capital social.

Em decorrência da dispersão do capital social e da consequente possibilidade de adoção de ações para a tomada do controle das companhias, revela-se importante o estudo das medidas defensivas contra o takeover.

Atualmente, o que se observa no Brasil em relação às proteções contra tomadas de controle hostis é, em muitos casos, a adoção de mecanismos típicos de ordenamentos jurídicos de outros países, especialmente aqueles utilizados nos EUA, que vêm sendo transplantados para o nosso sistema jurídico sem o adequado exame de admissibilidade e sem a necessária ponderação quanto à adequação às características próprias do nosso sistema legal ${ }^{21}$. Portanto, por meio deste trabalho, pretende-se examinar as proteções contra tomadas de controle hostis à luz da realidade brasileira.

\footnotetext{
${ }^{20}$ No Brasil, a estrutura de propriedade acionária é predominantemente concentrada. Entretanto, aos poucos, tornam-se cada vez mais frequentes companhias abertas brasileiras em que não há acionista (e/ou grupo de acionistas vinculado por Acordo de Acionistas) detendo mais da metade das ações votantes da companhia. $\mathrm{O}$ Jornal Valor Econômico, em 19 de junho de 2009, na matéria A Caminho da Pulverização, divulgou estudos realizados pelo Centro de Estudos em Governança - CEG indicando que dentre as companhias abertas brasileiras listadas em bolsa de valores: (i) 90,4\% possuem “controlador definido"; (ii) 8,3\% possuem “controle minoritário”; e (iii) 1,3\% possuem “capital pulverizado”. Sem adentrar no rigor técnico-jurídico utilizado para o enquadramento das companhias nestas categorias, o resultado demonstra que o Brasil ainda é expressivamente marcado pela concentração acionária. Em tal matéria, são referidas, exemplificativamente, como sendo “companhias com controle minoritário” (i.e., Eternit, Tecnosolo, Bernatech, Embraer, Totvs, Cia. Hering, BR Brokers, Dasa, GVT, Odontoprev, ALL, Perdigão, Itaú, Monteiro Aranha, Agra Incorporadora, Tempo Participações, Cremer, São Carlos, GPC Participações, Providência, Metalfrio, Brasil Agro, Cyrela Realty, Lupatech, Br Malls, PDG Realty, Minupar, ABNote, Romi, Aliança da Bahia, Klabin Segal e Kepler Weber) e a seguintes companhias como sendo "companhias de capital pulverizado", i.e., BM\&F Bovespa, Gafisa, Loja Renner, IdeiasNet e Dimed (VALENTI, Graziella; FREGONI, Silvia. A Caminho da Pulverização. Jornal Valor Econômico, 19.06.2009, p. D1).

${ }^{21}$ Calixto Salomão Filho faz importante alerta sobre as importações realizadas pelo Brasil de institutos do Direito Societário baseados na experiência dos EUA e da Inglaterra: "No campo societário essa importação leva a um sério problema de identidade. Realidades econômicas díspares não podem ter as mesmas estruturas empresariais. Caso se pretenda aproximar as realidades econômicas, então com mais razão ainda é preciso dar conformações estruturais distintas ao meio empresarial para que este possa se organizar. Assim, não é possível transportar para o Brasil a estrutura societária anglo-saxã, onde a importância do mercado de capitais e a diluição do poder societário funcionam como um elemento organizador natural para as sociedades, garantindo a autonomia dos administradores e promovendo a cooperação entre sócios” (SALOMÃO FILHO, Calixto. Direito Societário e Novo Mercado. In: . O Novo Direito Societário. 3. ed. São Paulo: Malheiros, 2006, p. 51). É também interessante o destaque de Bernard Black sobre a importação de institutos do modelo norte-americano, que dão origem às disfunções referidas como piggyback (BLACK, Bernard. Strengthening Brazil’s securities market. RDM. São Paulo: Malheiros, n. 120, pp. 41-55, out./dez. 2000, p. 50).
} 
Inicialmente, este trabalho analisará, de forma sumária, o poder de controle nas sociedades anônimas, discorrendo brevemente sobre a tipologia do poder de controle e os métodos de organização do controle interno e do controle externo, a fim de estabelecer alicerces que serão importantes para o desenvolvimento e evolução deste estudo.

Em seguida, será examinada a aquisição do poder de controle nas sociedades anônimas, analisando a ocorrência deste evento e explorando a classificação da aquisição do controle, especialmente em relação à distinção entre as aquisições de controle realizadas de forma amigável e de modo hostil. Serão abordados os métodos de aquisição do poder de controle, com especial interesse pela oferta pública de aquisição de controle.

A oferta pública de aquisição de controle é o mecanismo clássico para a tomada de controle hostil de companhia aberta. Quando há resistência à aquisição de controle por parte dos administradores e/ou determinados acionistas relevantes, tornando inviável uma aquisição negociada do controle, a oferta pública de aquisição revela-se instrumento eficiente, uma vez que é realizada diretamente aos acionistas, independentemente de aprovação por órgãos sociais e sem necessidade de acordo com determinado acionista relevante, ao contrário de outros métodos usuais de aquisição de controle ${ }^{22}$.

O exame da oferta pública de aquisição de ações será um dos núcleos deste trabalho e introduzirá o objetivo principal deste estudo, que são propriamente as medidas defensivas contra as tomadas de controle hostis. Será dedicada especial atenção à tipologia das medidas defensivas, propondo a distinção entre: (i) as medidas defensivas preventivas, que são aquelas adotadas anteriormente à divulgação da oferta pública de aquisição do controle da companhia-alvo, e (ii) as medidas defensivas posteriores, que são aquelas adotadas após a divulgação da oferta pública de aquisição do controle da companhia-alvo.

\footnotetext{
${ }^{22}$ Serão examinados no Capítulo III, item 3.2., alguns dos principais métodos de aquisição de controle no sistema jurídico brasileiro. Além das formas de aquisição de controle societário, a doutrina norte-americana pondera sobre as formas de aquisição de controle sobre ativos. Jesse Choper, John Coffee Jr. e Ronald Gilson ensinam que "in principle, control of productive assets of a corporation can be transferred in three ways. The acquiring corporation may (1) purchase the assets of the target corporation; (2) effect a merger with the target corporation; or (3) purchase a controlling block of the target company’s voting shares” (CHOPER, Jesse H.; COFFEE Jr., John C.; GILSON, Ronald J. Cases and materials on corporations. 7. ed. Nova York: Aspen Publishers, 2008, p. 939). A perspectiva a ser adotada neste trabalho será mais abrangente do que a concepção norte-americana do controle sobre ativos.
} 
Além disso, será lançada proposta de catalogação das medidas defensivas entre estatutárias, contratuais e institucionais.

Em seguida, serão examinadas algumas das espécies mais conhecidas de medidas defensivas, com análise crítica quanto à sua utilização no Brasil, traçando contornos sobre a validade da aplicação das mesmas em nosso sistema jurídico.

Após o estudo das medidas defensivas e o exame individualizado de cada uma das espécies mais conhecidas, serão observados os principais efeitos decorrentes de sua adoção, notadamente a estabilização da dispersão acionária, o efeito no preço de compra, o efeito disciplinar em relação à administração da companhia, o desestímulo ao investimento e o envolvimento da administração na negociação.

Nesse compasso, será feito o exame dos poderes e dos deveres que os órgãos de administração possuem em relação à adoção das proteções contra tomadas de controle. Será feita referência aos modelos de conduta (models of conduct) e aos padrões de revisão (standards of review) desenvolvidos pela jurisprudência norte-americana em relação a casos paradigmáticos na experiência dos EUA, que serviram como definidores dos deveres da administração naquele país e têm influenciado a abordagem do tema em outros sistemas jurídicos. Em seguida, o estudo será centrado nos poderes e deveres da administração com base nos parâmetros da legislação acionária brasileira, à luz do disposto nos artigos 153 a 157 da Lei $n^{\circ} 6.404 / 76$.

Por fim, será realizado breve exame do direito comparado em relação à matéria e analisado em que medida o Brasil se insere no contexto da utilização das medidas defensivas. Serão analisados estudos recentes de direito societário comparado que informam sobre a convergência de aspectos do direito societário em variados sistemas jurídicos. Conforme será verificado, as proteções contra takeovers hostis não são um destes temas convergentes, e o tratamento jurídico da matéria na Europa é bastante diferente do regime vigente nos EUA $^{23}$. Neste contexto, os poderes e funções dos órgãos de

\footnotetext{
${ }^{23}$ ARMOUR, John; SKEEL, Jr., David A. Who writes the Rules for Hostile Takeover, and Why? - The Peculiar Divergence of US and UK Takeover Regulation. European Corporate Governance Institute Working Paper Series in Law. n. 73, 2006, p. 2 e ss. (especialmente a partir da p. 19). Disponível em $<$ http://papers.ssrn.com/sol3/papers.cfm?abstract_id=928928>. Acesso em 12.12.2009.
} 
administração em relação a ofertas hostis são tratados de forma diferenciada na experiência comparada $^{24}$.

Concluindo o trabalho, serão expedidas as considerações finais sobre a utilização, no Brasil, de proteções contra tomadas de controle hostis de companhias abertas brasileiras, com a proposta de que os elementos importados ao Brasil pela prática empresarial devem ser compatibilizados e analisados com base em parâmetros do nosso sistema jurídico.

Não se pretende adotar postura favorável ou contrária à utilização de medidas defensivas contra tomadas de controle hostis, deixando-se este posicionamento para cada um dos casos concretos em que se fizer conveniente e/ou necessária a utilização de algum destes mecanismos. Por outro lado, pretende-se fornecer à comunidade jurídica e ao empresariado em geral fundamentos para a decisão quanto à adoção de tais proteções em determinadas hipóteses, sempre analisando o tema do ponto de vista jurídico.

\footnotetext{
${ }^{24}$ Henry Hansmann e Reinier Kraakman ensinam que os administradores norte-americanos dispõem de discricionariedade para a adoção de medidas defensivas em grau muito mais elevado do que os europeus. (HANSMANN, Henry; KRAAKMAN, Reinier R. The End of History for Corporate Law. Harvard Law School John M. Olin Center for Law, Economics, and Business Discussion Paper Series, n. 280, 2000 , pp. 20-21. Disponível em: <http://ssrn.com/abstract=204528>. Acesso em: 12.12.2009).
} 


\section{PODER DE CONTROLE}

\subsection{CONSIDERAÇões Preliminares}

As sociedades anônimas são estruturadas de forma orgânica. A Lei nº 6.404/76 disciplina expressamente os órgãos sociais que compõem as companhias e atribui poderesfunção específicos para cada um deles. Neste sentido, o poder-função deliberante é atribuído à Assembleia Geral; o poder-função administrativo, à Diretoria; e o poder-função sindicante, ao Conselho Fiscal ${ }^{25}$.

Os órgãos sociais são estruturados de forma hierarquizada nas sociedades anônimas, reconhecendo-se na Assembleia Geral o órgão soberano e prevalente em relação aos demais. José Luiz Bulhões Pedreira ensina que a companhia, como um grupo social do tipo societário, apresenta, como qualquer grupo social, uma estrutura hierarquizada, tendo a Assembleia Geral como órgão supremo, “à qual competem as decisões mais importantes e o poder de escolher administradores e fiscais” ${ }^{26}$. Os órgãos da administração, por sua vez, são subordinados à Assembleia Geral, que possui competência privativa para, a qualquer tempo, eleger ou destituir os administradores da companhia, nos termos do artigo 122, inciso II, da Lei $n^{\circ} 6.404 / 76$.

A Assembleia Geral, a Diretoria e o Conselho Fiscal são órgãos obrigatórios nas sociedades anônimas, esclarecendo-se que, em relação ao Conselho Fiscal, embora a lei acionária estabeleça a obrigatoriedade de sua existência, faculta-se ao estatuto social disciplinar sobre o seu funcionamento, que poderá ser permanente ou intermitente, neste caso se restringindo aos exercícios sociais em que for instalado a pedido de acionistas, conforme prevê o artigo 161 da Lei ${ }^{\circ}$ 6.404/76.

\footnotetext{
${ }^{25}$ Fábio Konder Comparato aponta que este é um dos elementos diferenciadores das sociedades anônimas em relação aos demais tipos societários (COMPARATO, Fábio Konder; SALOMÃO FILHO, Calixto. O Poder de Controle na Sociedade Anônima. 4 ed. Rio de Janeiro: Forense, 2005, p. 30).

${ }^{26}$ BULHÕES PEDREIRA, José Luiz. Parecer sobre controle e transferência de controle de empresas de telecomunicações. Proposta de regulamentação da ANATEL, relativo ao Projeto de "Regulamento de Apuração de Controle e Transferência de Controle em Empresas Prestadoras de Serviços de Telecomunicações”, submetido à consulta pública pela Anatel, 04.01.1999.
} 
Além desses órgãos sociais obrigatórios, faculta-se às sociedades anônimas a previsão da existência do Conselho de Administração, que se coloca como órgão intermediário entre a Diretoria e a Assembleia Geral. Em regra, o Conselho de Administração é órgão social facultativo no Brasil, tornando-se obrigatório apenas em determinados casos legalmente previstos ${ }^{27}$.

A distribuição dos poderes-função nas sociedades anônimas em que há Conselho de Administração é, de certa forma, afetada, uma vez que este órgão social tornase responsável pela orientação geral dos negócios da companhia e pelo exercício das demais competências que lhe são atribuídas pelo artigo 142 da Lei $n^{0}$ 6.404/76. Pode-se afirmar que a existência do Conselho de Administração dinamiza a companhia, na medida em que transfere determinadas funções que seriam exercidas pela Assembleia Geral para tal órgão social ${ }^{28}$.

Retomando as reflexões sobre a hierarquia da estruturação orgânica das sociedades anônimas, é importante destacar que a soberania da Assembleia Geral em relação aos demais órgãos sociais encontra previsão expressa na legislação acionária. O artigo 121 da Lei $n^{\circ}$ 6.404/76 estabelece que “a assembléia geral convocada e instalada de acordo com a lei e o estatuto, tem poderes para decidir todos os negócios relativos ao objeto da sociedade e tomar as resoluções que julgar conveniente à sua defesa e desenvolvimento”.

A influência dominante exercida na Assembleia Geral tende a se exteriorizar para os demais órgãos sociais, nos quais o poder de controle suscitará que o maior número de cargos nos órgãos de administração e fiscalização sejam ocupados por profissionais

\footnotetext{
${ }^{27}$ No Brasil, o Conselho de Administração é obrigatório nas companhias abertas, nas companhias de capital autorizado e nas sociedades de economia mista, conforme preveem os artigos 138 , $2^{\circ}$, e 239 da Lei ${ }^{\circ}$ $6.404 / 76$.

${ }^{28}$ Oportuno citar, a este propósito, o ensinamento de Rubens Requião: "O conselho de administração, órgão de deliberação, na verdade é intermediário entre a assembléia geral e a diretoria. Muitas das funções da antiga concepção de poderes da assembléia geral, dado o absenteísmo dos acionistas e desinteresse pelas reuniões de assembléia, foram pela teoria moderna transferidos para o conselho de administração, pois, ele, na teoria e na prática, efetivamente acolhe os acionistas controladores. Daí a competência ampla do conselho de administração que, como componente do órgão de execução, estabelece a política econômica, social e financeira a ser seguida pela sociedade, e exerce permanente vigilância sobre os executivos lotados na diretoria” (REQUIÃO, Rubens. Curso de direito comercial. v. 2, 20. ed. São Paulo: Saraiva, 1995, p. 158).
} 
eleitos por indicação daqueles acionistas que detenham participação acionária mais relevante na companhia.

Fábio Konder Comparato pondera que a afirmação legal do artigo 121 da Lei $n^{\circ}$ 6.404/76 não é suficiente para o entendimento da questão, por compreender que há situações em que o verdadeiro titular dos poderes decisórios não é acionista da companhia e, nestas hipóteses, a Assembleia Geral desempenhará suas prerrogativas sob influência dominante de soberania externa ${ }^{29}$.

\section{CONCEITO}

O sempre magistral Tullio Ascarelli define o poder de controle como a "possibilità di uno o più soggetti di imporre la propria decisione all'assemblea della società” ${ }^{30}$. Entretanto, a concepção moderna do poder de controle não se esgota simplesmente em tal definição, que não compreende aspectos relevantes previstos nos artigos 116 e 243 , $\S 2^{\circ}$, da Lei $n^{\circ} 6.404 / 76$.

De acordo com o caput do artigo 116 da Lei ${ }^{\circ}$ 6.404/76, acionista controlador é “a pessoa, natural ou jurídica, ou grupo de pessoas vinculadas por acordo de voto, ou sob controle comum, que: (a) é titular de direitos de sócio que lhe assegurem, de modo permanente, a maioria dos votos nas deliberações da Assembléia Geral e o poder de eleger a maioria dos administradores da companhia; e (b) usa efetivamente seu poder para dirigir as atividades sociais e orientar o funcionamento dos órgãos da companhia”.

O artigo 243, §2º , da Lei ${ }^{\circ}$ 6.404/76 prescreve que se considera “controlada a sociedade na qual a controladora, diretamente ou por meio de outras controladas, é titular de direitos de sócio que the assegurem, de modo permanente, preponderância nas deliberações sociais e o poder de eleger a maioria dos administradores”.

${ }^{29}$ COMPARATO, Fábio Konder; SALOMÃO FILHO, Calixto. O Poder de Controle na Sociedade Anônima. 4 ed. Rio de Janeiro: Forense, 2005, p. 39.

${ }^{30}$ ASCARELLI, Tullio. Problemi giuridici. Milão: Giuffré, 1959, p. 267, nota de rodapé 23. 
A redação dos dispositivos ${ }^{31}$ que conceituam o acionista controlador e a sociedade controlada é semelhante, adotando como essência a titularidade de direitos de sócio que assegurem, de modo permanente ${ }^{32}{ }^{33}$, a preponderância nas deliberações sociais e o poder de eleger a maioria dos administradores.

Entretanto, a alínea “b” do caput do artigo 116 da Lei nº 6.404/76 consagra que para a caracterização do controle é necessário o uso efetivo ${ }^{34}{ }^{35}$ dos direitos de sócios para

\footnotetext{
${ }^{31}$ Estudando a convergência do caput do artigo 116 e do §2 ${ }^{\circ}$ do artigo 243 da Lei ${ }^{\circ}$ 6.404/76, Eduardo Secchi Munhoz pondera que ambos os dispositivos referem-se "ao titular de direitos de sócio [...] que lhe assegurem [...] a maioria de votos nas deliberações da assembléia geral e o poder de eleger a maioria dos administradores da companhia" para definir o detentor do poder de controle. A partir desta evidência, o autor infere que a "lei acionária brasileira somente reconhece o controle derivado do mecanismo societário do direito de voto, o qual exclui, de plano, os fenômenos do controle gerencial e do controle externo" (MUNHOZ, Eduardo Secchi. Empresa Contemporânea e Direito Societário: poder de controle e grupo de sociedades. São Paulo: Juarez de Olivera, 2002, p. 242).

${ }^{32}$ A qualificação quanto à necessidade de que o exercício dos direitos de sócios "lhe assegurem, de modo permanente" o controle tem por objetivo evitar a configuração do poder de controle para situações eventuais, quando a preponderância nas deliberações sociais decorre de fato incerto. Calixto Salomão Filho sustenta que "o controle só pode representar o valor da organização quando gerar poder estável sobre ela" (COMPARATO, Fábio Konder; SALOMÃO FILHO, Calixto. O Poder de Controle na Sociedade Anônima. 4 ed. Rio de Janeiro: Forense, 2005, nota de texto n 9, p. 70). Fábio Konder Comparato (Ibid., p. 66) e Eduardo Secchi Munhoz (Op. cit., p. 243) sustentam que a expressão "permanente" não se refere à duração do controle no tempo, mas se opõe às situações de mera eventualidade, em que a preponderância nas deliberações sociais decorre de determinada conjuntura. Modesto Carvalhosa, por sua vez, assim preleciona: "O legislador, ao impor o requisito da permanência do poder decisório nas deliberações da assembléia geral, filiou-se às lições doutrinárias que excluem do conceito de controle o voto decisivo meramente episódico, eventual, futuro e difuso" (CARVALHOSA, Modesto. Comentários à Lei de Sociedades Anônimas. v. 2, 2. ed. São Paulo: Saraiva, 1998, p. 431).

${ }^{33}$ Sobre a permanência do poder de controle, a revogada Resolução CMN nº 401/76 estabelecia que só se caracterizava o poder de controle em determinada companhia, quando esse apresentasse requisito mínimo de estabilidade. O art. IV da Resolução CMN n ${ }^{\circ}$ 401/76 exigia "a maioria absoluta dos votos dos acionistas presentes nas três últimas assembléias gerais da companhia”. A Instrução CVM nº 229/95, com redação dada pela Instrução CVM n ${ }^{\circ}$ 345/00, assim estabelece em seu art. 2..: "Para os efeitos desta Instrução e da Instrução CVM n. ${ }^{\circ}$ 299, de 9 de setembro de 1999, entende-se por: [...] III - acionista controlador, a pessoa natural ou jurídica, ou grupo de pessoas vinculadas por acordo de acionistas, ou sob controle comum, ou representantes de um mesmo grupo de interesses, que nas três últimas Assembléias Gerais Ordinárias da Companhia detinha a maioria dos votos dos acionistas presentes, ou tenha adquirido o controle da Companhia conforme previsto nos artigos 254, 255 e 257 da Lei n. ${ }^{\circ}$ 6.404/76”. Os Regulamentos do Novo Mercado, do Nível 1 e do Nível 2 da BM\&F-Bovespa também contemplam a matéria da estabilidade na caracterização do controle e, ao conceituarem "poder de controle", preveem que este "significa o poder efetivamente utilizado de dirigir as atividades sociais e orientar o funcionamento dos órgãos da companhia de forma direta ou indireta, de fato ou de direito. Há presunção relativa de titularidade do controle em relação à pessoa ou ao grupo de pessoas vinculadas por acordo de acionistas ou sob controle comum ("grupo de controle"), que seja titular de ações que tenha assegurado a maioria absoluta dos votos dos acionistas presentes nas três últimas assembléias gerais da companhia, ainda que não seja titular das ações que lhe assegurem a maioria absoluta do capital votante".

${ }^{34}$ Mauro Rodrigues Penteado "julga necessária a comprovação do uso efetivo do poder de controle apenas no caso de controle minoritário, posto que a detenção da maioria das ações votantes sempre pressupõe o status de acionista controlador ou de sociedade controladora e de comando" (PENTEADO, Mauro Rodrigues. Apontamentos sobre a Alienação do Controle de Companhias Abertas. RDM. São Paulo: Malheiros, n. 76, pp. 15-25, out./dez. 1989, p. 16).
} 
dirigir as atividades sociais e orientar o funcionamento dos órgãos da companhia. Isto é, o poder de controle não decorre meramente de relações de direito, mas também pressupõe o exercício efetivo, a ser examinado com base em relações de fato ${ }^{36}$.

José Luiz Bulhões Pedreira informa que o poder de controle é, antes, poder de fato: “[...] nasce do fato da reunião da mesma pessoa (ou grupo de pessoas) da quantidade de ações cujos direitos de voto, quando exercidos no mesmo sentido, formam a maioria nas deliberações da Assembléia Geral”37. Em outra ocasião, o mesmo autor pôde esclarecer:

[...] poder de controle é essa modalidade de poder exercida pelo acionista (ou grupo de acionistas), pessoa natural ou jurídica, que é titular de direitos de voto suficientes para formar a maioria nas Assembléias Gerais. É poder de fato, e não jurídico. Não é direito contido na ação: cada ação confere apenas o direito (ou poder jurídico) de um voto, e o

${ }^{35} \mathrm{O}$ artigo 116 e o artigo 243, §2 ${ }^{\circ}$, da Lei $\mathrm{n}^{\circ}$ 6.404/76 possuem redações distintas em relação à necessidade do exercício efetivo do poder de controle. José Luiz Bulhões Pedreira e Alfredo Lamy Filho esclarecem que "o requisito de que a pessoa (ou grupo de pessoas) exerça efetivamente o poder de dirigir as atividades sociais e orientar o funcionamento dos órgãos da companhia se explica porque a definição do artigo 116 da Lei abrange pessoas naturais, e a experiência mostra que há pessoas naturais que, embora sejam titulares da maioria dos votos, não exercem efetivamente o poder de controle, como no caso da viúva do empresário que o sucede na maioria dos direitos de voto mas deixa a administração da companhia entregue aos administradores profissionais em que o marido confiava, sem exercer efetivamente o poder de controle. (...) a Lei não inclui este requisito na definição de sociedade controladora, constante no $\S 2^{\circ}$ do artigo 243 , porque a sociedade existe para realizar seu objeto e, se este inclui a participação em companhia, ela exerce seus direitos de sócio” (LAMY FILHO, Alfredo; BULHÕES PEDREIRA, José Luiz. Direito das Companhias. v. 1, Rio de Janeiro: Forense, 2009, p. 817).

${ }^{36}$ Além da distinção quanto ao uso efetivo do poder de controle, há diferenças importantes nas redações adotadas no artigo 116 e no artigo 243, $\S 2^{\circ}$, da Lei $n^{\circ} 6.404 / 76$, sobre as quais a doutrina pátria estabelece importantes ponderações. Eduardo Secchi Munhoz ensina que "ao estabelecer que é acionista controlador 'o grupo de pessoas [...] sob controle comum, o art. 116 não admite o controle indireto, considerando controlador aquele acionista que diretamente é titular de direitos de sócio na controlada, ainda que, por sua vez, seja controlado por terceiros. De forma diversa, o art. 243, $\S 2^{\circ}$, da Lei $n^{0} 6.404 / 76$ estabelece que é controlada a sociedade na qual, diretamente ou através de outras controladas, é titular de direitos de sócio [...]', reconhecendo, portanto, a hipótese de controle indireto e atribuindo a condição de controladora à sociedade situada no ápice da pirâmide” (MUNHOZ, Eduardo Secchi. Empresa Contemporânea e Direito Societário: poder de controle e grupo de sociedades. São Paulo: Juarez de Olivera, 2002, p. 241). No mesmo sentido, Fábio Konder Comparato explica que "na hipótese de incidência definida no art. 116, o controle é sempre direto e as sociedade sob controle comum são tidas, em conjunto, por controladoras. No art. 243, $\S 2^{\circ}$, despreza-se o escalão intermédio, buscando-se a sociedade controladora em último grau” (COMPARATO, Fábio Konder; SALOMÃO FILHO, Calixto. O Poder de Controle na Sociedade Anônima. 4 ed. Rio de Janeiro: Forense, 2005, p. 85).

${ }^{37}$ BULHÕES PEDREIRA, José Luiz. Alienação de Controle de Companhia Aberta. In: LAMY FILHO, Alfredo; BULHÕES PEDREIRA, José Luiz. A Lei das S.A.. v. 2, 2. ed. Rio de Janeiro: Renovar, 1996, p. 620. 
poder de controle nasce do fato da reunião na mesma pessoa (ou no mesmo grupo de pessoas) de quantidade de direitos de voto $[\ldots]^{38}$.

A expressão “controle de companhia” é ambígua, conforme expõem José Luiz Bulhões Pedreira e Alfredo Lamy Filho, distinguindo o emprego da mesma com o significado de "poder de controle" e de "bloco de controle", que são conceitos distintos 39 . A distinção destes conceitos é especialmente importante em relação aos métodos de aquisição e/ou obtenção do poder de controle, que serão examinados no item 3.2.

Fábio Konder Comparato caracteriza o poder de controle como um poder originário, uno ou exclusivo e geral ${ }^{40}$. Originário porque não deriva e/ou se funda em nenhum outro, interna ou externamente; uno ou exclusivo porque não admite concorrentes, pela sua própria natureza; geral porque se exerce em todos os campos e setores, sem encontrar nem admitir domínios reservados, por parte dos órgãos societários.

A estrutura de poder exterioriza-se nas sociedades anônimas em três níveis: (i) participação no capital; (ii) direção; e (iii) controle. O controle pode provir da participação no capital social, mas não se confunde com ela e, conforme examinado acima, há situações em que o verdadeiro titular do poder decisório não é acionista.

O entendimento recente da doutrina sobre a matéria propõe que essas estruturas de poder nas sociedades anônimas não sejam consideradas como esferas de poder estanques, mas sim interdependentes, que exercem influência recíproca, a cada momento da vida empresarial ${ }^{41}$.

\footnotetext{
${ }^{38}$ BULHÕES PEDREIRA, José Luiz. Parecer sobre controle e transferência de controle de empresas de telecomunicações. Proposta de regulamentação da ANATEL, relativo ao Projeto de "Regulamento de Apuração de Controle e Transferência de Controle em Empresas Prestadoras de Serviços de Telecomunicações”, submetido à consulta pública pela Anatel, 04.01.1999.

${ }^{39}$ LAMY FILHO, Alfredo; BULHÕES PEDREIRA, José Luiz. Direito das Companhias. v. 1, Rio de Janeiro: Forense, 2009, p. 823.

${ }^{40}$ COMPARATO, Fábio Konder; SALOMÃO FILHO, Calixto. O Poder de Controle na Sociedade Anônima. 4 ed. Rio de Janeiro: Forense, 2005, p. 49.

${ }^{41}$ A este respeito, confiram-se: MUNHOZ, Eduardo Secchi. Empresa Contemporânea e Direito Societário: poder de controle e grupo de sociedades. São Paulo: Juarez de Olivera, 2002, p. 223; e MACEDO, Ricardo Ferreira de. Limites de efetividade do direito societário na repressão ao uso disfuncional do poder de controle nas sociedades anônimas. RDM. São Paulo: Malheiros, n. 120, pp. 195-227, out./dez. 2000, pp. 195-173.
} 
Portanto, o poder de controle deve ser reconhecido como um elemento dinâmico, mutável e suscetível a alterações nas companhias, sendo inclusive potencial objeto de disputas. Neste sentido, em países com grande número de companhias abertas dotadas de dispersão acionária, desenvolveu-se o chamado market for corporate control $^{42}$ ${ }^{43}$, que, em tradução para o nosso idioma, com preservação de seu sentido original, pode ser referido como "mercado para o controle societário" 44 .

Há casos em que as ações votantes de emissão de determinadas companhias abertas estão tão dispersas no mercado, que certas operações de aquisição e alienação de ações, realizadas em bolsas de valores e/ou por oferta pública, são capazes de ocasionar transferência de controle.

No Brasil, ainda não existe tal mercado para o controle societário. Todavia, em outros países com economias de mercado altamente desenvolvidas, em que é frequente a existência de companhias abertas com dispersão acionária, como ocorre, por exemplo, nos EUA e na Inglaterra, o mercado para o controle societário existe há tempos e faz parte da realidade empresarial, jurídica e econômica ${ }^{45}$.

\subsection{Tipologia do Poder Controle}

Não nos alongaremos na tipologia do poder de controle, a fim de não desequilibrar a estrutura deste trabalho, mesmo porque o tema já foi profundamente

\footnotetext{
${ }^{42}$ Para maiores informações sobre o conceito de market for corporate control, referir-se a ROMANO, Roberta (Coord.). Foundations of Corporate Law. 2. re-imp. Nova York: Foundation Press, 2004, notadamente no capítulo VI - "External Governance Structures: The Market for Corporate Control” -, em que são reunidos textos de diversos autores sobre o tema.

${ }^{43}$ Sobre os efeitos benéficos do market for corporate control referir-se a JENSEN, Michael C. Takeovers: their causes and consequences. Journal of Economic Perspectives. v. 2, n. 1, 1988, pp. 21-48. Disponível em SSRN: <http://ssrn.com/abstract=173455> . Acesso em 12.12.2009.

${ }^{44}$ Em Portugal, a expressão market for corporate control é usualmente traduzida como mercado de controlo.

${ }^{45}$ A doutrina estrangeira noticia que o mercado para o controle societário é cada vez mais presente na Europa Continental, com destaque à Alemanha e às operações realizadas em âmbito europeu envolvendo companhias de países diferentes (cross-border mergers). Neste sentido, GORDON, Jeffrey N. An American Perspective on the New German Anti-takeover Law. ECGI - Law Working Paper, n. 02, 2002; Columbia Law and Economics Working Paper, n. 209; Harvard Law and Economics Discussion Paper, n. 407. Disponível em SSRN: $<$ http://ssrn.com/abstract=336420 $>$. Acesso em 12.12.2009.
} 
estudado $^{46}$. A tipologia do poder de controle deve ser aqui examinada principalmente para identificar as companhias mais suscetíveis à tomada de controle, a fim de estabelecer alicerces que serão importantes para o desenvolvimento e evolução deste trabalho.

Recorrendo às lições de Fábio Konder Comparato sobre a tipologia básica do poder de controle, distingue-se este entre interno e externo. No controle interno, o titular do poder de controle atua no interior da sociedade ( $a b$ intus), valendo-se dos mecanismos de poder próprios da estrutura societária, notadamente a deliberação em Assembleia Geral e a representação nos órgãos de administração ${ }^{47}$. Por outro lado, no controle externo, o poder de dominação em relação à sociedade pertence a uma ou mais pessoas, físicas ou jurídicas, que não compõem quaisquer órgãos da sociedade, mas agem de fora ( $a b$ extra) 48.

\subsubsection{CONTROLE INTERNO}

É notória a proposta doutrinária de Berle e Means ${ }^{49}$ para a subdivisão em categorias do controle interno: (i) controle quase totalitário; (ii) controle majoritário; (iii) controle minoritário; (iv) controle gerencial; e (v) controle mediante expedientes legais.

\footnotetext{
${ }^{46}$ Na doutrina pátria, referir-se, sempre e por todos, a COMPARATO, Fábio Konder; SALOMÃO FILHO, Calixto. O Poder de Controle na Sociedade Anônima. 4. ed. Rio de Janeiro: Forense, 2005. É mandatória também a referência ao moderno e festejado recenseamento proposto por Eduardo Secchi Munhoz (MUNHOZ, Eduardo Secchi. Empresa contemporânea e Direito Societário. Poder de Controle e Grupos de Sociedade. SP: Juarez de Oliveira, 2002), que inclusive mereceu elogios públicos de Mauro Rodrigues Penteado (PENTEADO, Mauro Rodrigues. Nota Bibliográfica ao livro Empresa Contemporânea e Direito Societário. Poder de Controle e Grupos de Sociedades, de Eduardo Secchi Munhoz. RDM. São Paulo: Malheiros, n. 133, pp. 301-302, jan./mar. 2004). Deve-se referir-se também às contribuições de MACEDO, Ricardo Ferreira de. Controle Não Societário. Rio de Janeiro: Renovar, 2004; e PEREIRA, Guilherme Döring Cunha. Alienação do Poder de Controle Acionário. São Paulo: Saraiva, 1995. Na doutrina estrangeira, a obra clássica de Berle e Means, nascente original das reflexões sobre o tema, é parada obrigatória (BERLE, Adolf A.; MEANS, Gardiner C. The modern corporation and private property. 9. ed. New Brunswick / New Jersey: Transaction Publishers, 2007).

${ }^{47}$ COMPARATO, Fábio Konder; SALOMÃO FILHO, Calixto. Op. cit., p. 48.

48 Ibid., 89.

49 BERLE, Adolf A.; MEANS, Gardiner C. The modern corporation and private property. 9. ed. New Brunswick / New Jersey: Transaction Publishers, 2007, p. 67.
} 
Fábio Konder Comparato propõe a supressão desta última categoria de subdivisão do controle interno, mantendo todas as demais ${ }^{50}$.

Adotando-se, então, a proposta de Berle e Means, com a adaptação sugerida por Fábio Konder Comparato, serão consideradas neste trabalho as subdivisões do controle interno, analisadas nas linhas seguintes.

\subsubsection{CONTROLE QUASE Totalitário}

O poder de controle, neste caso, é fundado na titularidade de quase todas as ações de emissão da companhia. Berle e Means entendem que as sociedades unipessoais também poderiam ser enquadradas nesta modalidade ${ }^{51}$. Fábio Konder Comparato, por outro lado, opõe-se a este enquadramento, sob o fundamento de que nas sociedades unipessoais "não há nenhum outro interesse interno a ser levado em consideração, na aplicação das normas legais, além do interesse do titular único do capital social” ${ }^{\text {52. }}$.

A legislação acionária brasileira consagra o princípio majoritário, reconhecendo que, em regra, as deliberações da Assembleia Geral são aprovadas por maioria de votos, não se computando os votos em branco, a teor do que dispõe o caput do artigo 129 da Lei $n^{\circ}$ 6.404/76. Portanto, o titular do controle quase totalitário pode, de forma geral, aprovar as deliberações submetidas à Assembleia Geral.

É importante destacar a existência de determinadas matérias para as quais a legislação acionária brasileira exige expressamente a unanimidade para sua aprovação ${ }^{53}$.

${ }^{50}$ COMPARATO, Fábio Konder; SALOMÃO FILHO, Calixto O Poder de Controle na Sociedade Anônima. 4. ed. Rio de Janeiro: Forense, 2005, pp. 64; 79.

${ }^{51}$ BERLE, Adolf A.; MEANS, Gardiner C. The modern corporation and private property. 9. ed. New Brunswick / New Jersey: Transaction Publishers, 2007, p. 67.

52 COMPARATO, Fábio Konder; SALOMÃO FILHO, Calixto. Op. cit., p. 53.

${ }^{53}$ São matérias de unanimidade: (i) a alteração do projeto do estatuto social durante a fase constitutiva da sociedade (artigo 87, §2º , da Lei $n^{\circ}$ 6.404/76); (ii) a transformação (artigo 221 da Lei $n^{\circ}$ 6.404/76), exceto quando prevista no estatuto social, caso em que o sócio dissidente terá o direito de retirar-se da sociedade; (iii) a cisão parcial desproporcional (artigo 229, §5º da Lei ${ }^{\circ}$ 6.404/76); (iv) o pagamento de participação aos administradores (artigo 294, §2 $2^{\circ}$, da Lei $\mathrm{n}^{\circ}$ 6.404/76); e (v) a mudança de nacionalidade (artigo 71 do Decreto-Lei $n^{\circ}$ 2.627/40 e artigo 1.127 do Código Civil). 
Em relação às matérias de unanimidade, o titular do controle quase totalitário, por razões óbvias, não conseguirá aprová-las isoladamente.

\subsubsection{CONTROLE MAJORITÁRIO}

O controle majoritário é aquele exercido por acionista e/ou grupo de acionistas que, em conjunto ou isoladamente, detém ações de determinada companhia em quantidade superior à metade do capital social votante, assegurando-lhe o poder de controle.

Tal como exposto acima, em consonância com o princípio majoritário consagrado pela legislação acionária brasileira, as deliberações da Assembleia Geral são, em regra, aprovadas por maioria de votos, de modo que o titular do controle majoritário pode aprovar as deliberações submetidas à Assembleia Geral, sem a necessidade do concurso dos demais acionistas, observadas as matérias de quorum especial previstas em lei.

A tipologia do poder de controle prevê a subdivisão do controle majoritário em: (i) controle majoritário isolado, que é aquele exercido isoladamente por um único acionista detentor da maioria das ações votantes da companhia; e (ii) controle majoritário conjunto, que é aquele exercido por acionistas que, quando reúnem as suas respectivas participações acionárias, detêm a maioria do capital social votante da companhia. O controle majoritário conjunto pode também ser referido como controle compartilhado ${ }^{54}$.

O controle majoritário conjunto é usualmente estabelecido por meio de convenções de voto estabelecidas em acordo de acionistas, celebrados, nos termos do artigo 118 da Lei $n^{\circ}$ 6.404/76, entre acionistas que, temporária ou permanentemente, possuem interesses convergentes e desejam dispor sobre os termos e condições para o exercício compartilhado do poder de controle.

\footnotetext{
${ }^{54}$ A título meramente exemplificativo, refira-se a Nelson Cândido Motta ao prever que "nas companhias comandadas por grupo de acionistas, o poder de controle é um atributo coletivo e compartilhado" (MOTTA, Nelson Cândido. Alienação do poder de controle compartilhado. RDM. São Paulo: Malheiros, n. 89, jan./mar. 1993, p. 43).
} 


\subsubsection{CONTROLE MinORITÁRIO}

O controle minoritário é aquele exercido por acionista e/ou grupo de acionistas que, em conjunto ou isoladamente, detém número de ações de determinada companhia em quantidade inferior à metade do capital social votante.

A manifestação dessa espécie de controle se dá, usualmente, quando há dispersão do capital social e não há na companhia nenhum acionista e/ou grupo de acionistas que detenha a maioria das ações com direito de voto. Consequentemente, há a possibilidade de o poder de controle ser exercido por alguém que detenha participação acionária em quantidade inferior à metade do capital social votante.

O controle minoritário organizado pode atuar de modo eficiente em relação à companhia e pode estar dotado das mesmas prerrogativas aplicáveis às espécies tradicionais de exercício do poder de controle (i.e., controle quase totalitário e controle majoritário). Entretanto, é importante notar a existência de determinadas matérias, expressamente previstas na legislação acionária brasileira, para as quais se exige quorum específico de aprovação, como, por exemplo, o quorum de maioria do capital com direito a voto para a aprovação das matérias listadas no artigo 136 da Lei $n^{0} 6.404 / 76^{55}{ }^{56}$. Isto é,

\footnotetext{
${ }^{55} \mathrm{O}$ artigo 136 da Lei $\mathrm{n}^{\circ}$ 6.404/76 estabelece a necessidade de aprovação de acionistas que representem metade, no mínimo, das ações com direito a voto para deliberação sobre: (i) criação de ações preferenciais ou aumento de classe de ações preferenciais existentes, sem guardar proporção com as demais classes de ações preferenciais, salvo se já previstos ou autorizados pelo estatuto; (ii) alteração nas preferências, vantagens e condições de resgate ou amortização de uma ou mais classes de ações preferenciais, ou criação de nova classe mais favorecida; (iii) redução do dividendo obrigatório; (iv) fusão da companhia, ou sua incorporação em outra; (v) participação em grupo de sociedades; (vi) mudança do objeto da companhia; (vii) cessação do estado de liquidação da companhia; (viii) criação de partes beneficiárias; (ix) cisão da companhia; e (x) dissolução da companhia.

${ }^{56}$ As matérias de unanimidade referidas na nota de rodapé $n^{\circ} 53$ também se enquadram no rol das matérias que o detentor do poder de controle minoritário não poderá aprovar sem o concurso de outros acionistas. Além de tais matérias, (i) a aprovação de condições especiais para a partilha do ativo remanescente nos casos de liquidação (artigo 215, $\S 1^{\circ}$ ), devendo-se esclarecer que todas as ações têm direito a voto, independentemente de espécie ou classe, enquanto durar o estado de liquidação (artigo 213, $\S 1^{\circ}$ ); e (ii) em relação às sociedades em comandita por ações, a destituição de diretores ou gerentes da sociedade (artigo 282, $\S 1^{\circ}$ ), também são matérias que o detentor do controle minoritário não conseguirá aprovar sozinho.
} 
em uma companhia organizada sob controle minoritário, há matérias que o detentor do poder de controle não poderá aprovar sem o concurso dos demais acionistas da companhia.

\subsubsection{CONTROLE GERENCIAL}

O controle gerencial ou administrativo, ao qual a experiência norte-americana se refere como management control, é aquele que não se funda em participação acionária, mas tão-somente em prerrogativas de poder em relação à companhia decorrentes do exercício de funções diretivas.

Há casos em que, em consequência da extrema dispersão das ações de determinada companhia no mercado e de postura absenteísta de acionistas com participações relevantes, os administradores assumem o poder de controle.

Ocorre assim a chamada auto-perpetuação dos administradores da companhia, que é empreendida por meio da proxy gathering machine ou proxy machinery, assim amplamente referida na doutrina pátria ${ }^{57}$, que consiste em pedidos públicos de procuração realizados pelos administradores aos acionistas da companhia ${ }^{58}$.

Trata-se de mecanismo utilizado normalmente em casos de companhias com base acionária dispersa, por meio do qual a administração envia aos acionistas documentos gerenciais referentes à companhia, como, por exemplo, relatórios de desempenho, prognósticos, propostas e metas de gestão, sobretudo nos casos em que a companhia vem apresentando resultados positivos ou adequados à perspectiva pré-estabelecida, acompanhados por procuração pela qual tais acionistas outorgam poderes aos

${ }^{57}$ Exemplificativamente: (i) COMPARATO, Fábio Konder; SALOMÃO FILHO, Calixto. O Poder de Controle na Sociedade Anônima. 4. ed. Rio de Janeiro: Forense, 2005, p. 72; (ii) MACEDO, Ricardo Ferreira de. Controle Não Societário. Rio de Janeiro: Renovar, 2004, p. 129; (iii) PEREIRA, Guilherme Döring Cunha. Alienação do Poder de Controle Acionário. São Paulo: Saraiva, 1995, p. 13; e (iv) MUNHOZ, Eduardo Secchi. Empresa Contemporânea e Direito Societário: poder de controle e grupo de sociedades. São Paulo: Juarez de Oliveira, 2002, p. 235.

${ }^{58}$ Os pedidos públicos de procuração encontram amparo legal, em nosso ordenamento jurídico, no artigo 126, §2 ${ }^{\circ}$, da Lei $\mathrm{n}^{\circ} 6.404 / 76$, e vêm sendo objeto de constantes reflexões no atual estágio evolutivo do mercado de capitais brasileiro. A CVM editou recentemente a Instrução CVM n ${ }^{\circ} 481 / 090$ tratando das informações e pedidos públicos de procuração para exercício do direito de voto. 
administradores para representá-los em assembleias gerais, exercendo o direito de voto atribuível aos acionistas. São usuais também instruções de voto acompanhando tais procurações, orientando o sentido em que o voto deverá ser exercido pelo mandatário.

Nelson Eizirik, em opinião expressada em 1987, ponderou que “não existe, no Brasil, nenhum caso de empresa que possa ser classificada como controlada pela direção" ${ }^{59}$. Ricardo Ferreira de Macedo opõe-se a este entendimento, por compreender que “a situação de controle gerencial pode ser efeito não apenas de ambiente de pulverização acionária, mas, também, de outros cenários fáticos em que se veja a vacuidade de influência dos sócios sobre a administração" ${ }^{00}$. A despeito da reconhecida e expressiva evolução recente do mercado de capitais brasileiro, entendemos que as reflexões de Nelson Eizirik ainda são igualmente aplicáveis aos tempos atuais e, ainda, não há controle gerancial em companhias abertas brasileiras.

\subsubsection{CONTROLE EXTERNO}

O controle externo ocorre quando o poder de dominação em relação à companhia é exercido por alguém que não integra os órgãos sociais internos da companhia. Isto é, a ingerência em relação à companhia é exercida $a b$ extra, por alguém que não é acionista e/ou ocupa cargos em órgãos de administração e/ou fiscalização da companhia.

José Luiz Bulhões Pedreira e Alfredo Lamy Filho sintetizam que, no controle externo, a influência dominante sobre a companhia dá-se "com fundamento em contratos desta com terceiros ou de poder cuja fonte são as relações de participação nos mercados”61.

\footnotetext{
${ }^{59}$ EIZIRIK, Nelson. O mito do "controle gerencial” - alguns dados empíricos. RDM. São Paulo: Malheiros, n. 66, pp.103-106, abr./jun., 1987, p. 106.

${ }^{60}$ MACEDO, Ricardo Ferreira de. Controle Não Societário. Rio de Janeiro: Renovar, 2004, p. 135. Ricardo Ferreira de Macedo complementa, exemplificando, que se pode "cogitar da ocorrência de situação de controle gerencial no âmbito de uma empresa societária cujo capital mostre-se extremamente concentrado, em mãos de dois sócios, por exemplo, os quais, por qualquer motivo, deixem de realizar assembléias ou reuniões de quotistas por dilatado espaço de tempo e deixem também de se manifestar por qualquer outra forma acerca dos negócios sociais”.

${ }^{61}$ LAMY FILHO, Alfredo; BULHÕES PEDREIRA, José Luiz. Direito das Companhias. v. 1, Rio de Janeiro: Forense, 2009, p. 831.
} 
Ricardo Ferreira de Macedo utiliza-se da expressão “deslocamento extrasocietário" para designar a "flutuação das prerrogativas decisórias de uma empresa da lei acionária para a esfera de outro stakeholder situado fora do quadro societário"62.

O fenômeno do controle externo caracteriza-se em situações nas quais, conforme assinala Guilherme Döring Cunha Pereira, “a última palavra na orientação da empresa não procede de um acionista nem dos administradores da sociedade״ ${ }^{\text {63 }}$, mas de centros decisórios estranhos à estrutura orgânica da companhia. Estes centros decisórios podem ser credores relevantes ${ }^{64}$, fornecedores de produtos e matérias-primas em situação de oligopólio ou monopólio, franqueadores, consumidores ou compradores em situações de oligopsônio ou monopsônio, dentre outros casos.

Guilherme Döring Cunha Pereira ${ }^{65}$, valendo-se das lições do autor italiano Carlo Pasteris ${ }^{66}$, e Ricardo Ferreira de Macedo ${ }^{67}$, endossando as ideias de Guilherme Döring Cunha Pereira, asseveram que nem sempre a influência externa se constitui em um controle externo. Para que se configure o controle externo, devem estar presentes algumas características relacionais entre quem exerce a influência e que é influenciado, quais sejam:

a) que a influência seja de ordem econômica; b) que a influência se estenda a toda a atividade desenvolvida pela empresa controlada; c) que se trate de um estado de subordinação permanente ou, pelo menos, duradouro; e d) que haja impossibilidade para a controlada de subtrair-se à influência, sem séria ameaça de sofrer grave prejuízo econômico ${ }^{68}$.

\footnotetext{
${ }^{62}$ MACEDO, Ricardo Ferreira de. Controle Não Societário. Rio de Janeiro: Renovar, 2004, p. 106.

${ }^{63}$ PEREIRA, Guilherme Döring Cunha. Alienação do Poder de Controle Acionário. São Paulo: Saraiva, 1995, p. 4.

${ }^{64}$ A Lei ${ }^{\circ}$ 6.404/76 prevê, nos artigos 113 e 114, possibilidade de assegurar aos credores garantidos por penhor, usufruto ou alienação fiduciária de ações, ingerência sobre o exercício do direito de voto.

${ }^{65}$ PEREIRA, Guilherme Döring Cunha. Op. cit., p. 14.

${ }^{66}$ PASTERIS, Carlo. Il controllo. Milão: Giuffrè, 1957, p. 31 e ss. Apud PEREIRA, Guilherme Döring Cunha. Op. cit., p. 14.

${ }^{67}$ MACEDO, Ricardo Ferreira de. Op. cit., p. 123.

${ }^{68}$ PASTERIS, Carlo. Op. cit., p. 14.
} 
A existência do controle externo não suprime a existência dos órgãos sociais internos da companhia ${ }^{69}$. Na verdade, tais órgãos sociais passam a atuar segundo a influência dominante daquele que se coloca em posição de dominação externa.

A Lei $n^{0}$ 6.404/76 dispõe apenas sobre o controle interno da companhia e não trata do controle externo, conforme manifestação recorrente da melhor doutrina, com destaque às respeitáveis opiniões de José Luiz Bulhões Pedreira e Alfredo Lamy Filho ${ }^{70}$ e de Fábio Konder Comparato ${ }^{71}$.

\section{Controle Concentrado vs. ConTrole Difuso}

As companhias abertas com intensa dispersão acionária, que são comuns nos EUA e na Inglaterra, ainda não são frequentes na realidade brasileira ${ }^{72}$. Já foi exposto que o Brasil, por inúmeras razões econômicas e em decorrência do processo evolutivo tardio de nosso sistema capitalista, é reconhecidamente um país de extrema concentração acionária $^{73}$.

\footnotetext{
${ }^{69}$ Segundo Eduardo Secchi Munhoz, “o controlador externo tem o poder de fazer com que sua orientação prepondere no âmbito da assembléia geral e, por conseqüência, dos órgãos administrativos da sociedade, pela possibilidade de aplicação de uma sanção econômica, ou mesmo jurídica, como, por exemplo, a resolução de um determinado contrato" (MUNHOZ, Eduardo Secchi. Empresa Contemporânea e Direito Societário: poder de controle e grupo de sociedades. São Paulo: Juarez de Olivera, 2002, p. 227).

${ }^{70}$ LAMY FILHO, Alfredo; BULHÕES PEDREIRA, José Luiz. Direito das Companhias. v. 1, Rio de Janeiro: Forense, 2009, p. 832.

${ }^{71}$ COMPARATO, Fábio Konder; SALOMÃO FILHO, Calixto. O Poder de Controle na Sociedade Anônima. 4. ed. Rio de Janeiro: Forense, 2005, p. 39- 40.

${ }^{72}$ Conforme preleciona Eduardo Secchi Munhoz, referindo-se a trabalhos que comparam os sistemas de controle no mundo, a estrutura de controle diluído é dominante apenas nos EUA e no Reino Unido (MUNHOZ, Eduardo Secchi. Desafios do direito societário brasileiro na disciplina da companhia aberta: avaliação dos sistemas de controle diluído e concentrado. In: CASTRO, Rodrigo R. Monteiro; ARAGÃO, Leandro Santos de. Direito Societário: Desafios Atuais. São Paulo: Quartier Latin, pp. 119-155, 2009, p. 127).

${ }^{73}$ Estudos empíricos recentes revelam que as companhias abertas brasileiras são caracterizadas pela concentração acionária. Exemplificativamente, referir-se à pesquisa de: (i) VALADARES, Silvia Mourthé; e LEAL, Ricardo Pereira Câmara. VALADARES, Silvia Mourthé; LEAL, Ricardo Pereira Câmara. Ownership and Control Structure of Brazilian Companies. 2000. Disponível em SSRN: $<$ http://ssrn.com/abstract=213409> . Acesso em: 12.12.2009, que, a partir da análise dos IANs de 325 companhias abertas brasileiras, referentes ao exercício social de 1996, constatou que 62,5\% das companhias analisadas possuíam um acionista detentor de $74 \%$ do capital social votante da companhia. Outras constatações de tal pesquisa também revelam o perfil de concentração acionária característico das
} 
Entretanto, os últimos anos vêm demonstrando crescimento do mercado de capitais brasileiro e evidenciando que, em futuro próximo, algumas reflexões deverão ser feitas em relação às companhias abertas brasileiras organizadas com dispersão acionária. Dentre as companhias abertas recém-ingressas no segmento especial do Novo Mercado BM\&F-Bovespa, há notável crescimento do número de companhias com estrutura acionária organizada com dispersão ${ }^{74}$.

A BM\&F-Bovespa, por meio de seus regulamentos de práticas de governança corporativa, prevê a possibilidade de as companhias se organizarem mediante o controle concentrado ou o controle difuso.

Na acepção da BM\&F-Bovespa, controle difuso significa o poder de controle “exercido por acionista detentor de menos de 50\% do capital social, assim como por grupo de acionistas que não seja signatário de acordo de votos e que não esteja sob controle comum e nem atue representando um interesse comum." ${ }^{75}$

A própria $B M \& F-B o v e s p a$ propõe a interpretação extensiva desse conceito, entendendo tratar-se do poder de controle “exercido por (i) acionista detentor de menos de $50 \%$ do capital social, (ii) por grupo de acionistas detentor de percentual superior a 50\% do capital social em que cada acionista detenha individualmente menos de $50 \%$ do capital social e desde que estes acionistas não sejam signatários de acordo de votos, não estejam sob controle comum e nem atuem representando um interesse comum, bem como (iii) por acionistas signatários de acordo de votos que em conjunto sejam detentores de menos de $50 \%$ do capital social da companhia” ${ }^{\text {76 }}$.

companhias abertas brasileiras; e (ii) GORGA, Erica. Changing the Paradigm of Stock Ownership: From Concentrated Towards Dispersed Ownership? Evidence from Brazil and Consequences for Emerging Countries. 3rd Annual Conference on Empirical Legal Studies Papers. Abr. 2008. Disponível em SSRN:

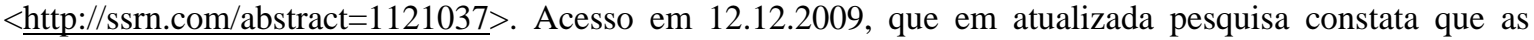
características de concentração acionária se mantêm, mas as novas companhias abertas ingressantes no segmento especial do Novo Mercado da BM\&F-Bovespa, cada vez mais frequentemente, adotam estruturas de dispersão acionária.

${ }^{74}$ Ibid.

${ }^{75}$ Desta forma preveem os Regulamentos do Novo Mercado, Nível 1 e Nível 2 da BM\&F-Bovespa.

76 BM\&F-BOVESPA. Empresas: Governança Corporativa - Perguntas frequentes. Disponível em $<$ http://www.bovespa.com.br/empresas/novomercadoniveis/novomercadofaq.asp>. Acesso em 12.12.2009. 
Contrario sensu e por exclusão, entende-se que todas as demais companhias, que não tenham poder de controle organizado de forma difusa, o têm de forma concentrada.

Em esforço de compatibilização da tipologia de poder de controle proposta pela BM\&F-Bovespa com aquela adotada predominantemente pela doutrina, pode-se identificar que o controle concentrado compreende o controle quase totalitário e o controle majoritário, enquanto o controle difuso contempla o controle minoritário e o controle gerencial. Portanto, os critérios adotados pela BM\&F-Bovespa não levam em consideração o controle externo.

A fim de identificar quais são as companhias mais suscetíveis à aquisição hostil de seu controle, é importante associar as companhias organizadas sob controle difuso à conceituação do controle minoritário e do controle gerencial, pois são estas as mais expostas às tentativas de tomada de controle.

A existência da dispersão acionária é premissa essencial para a tomada de controle. A aquisição de controle em companhia com concentração acionária pressupõe a concordância entre o detentor do poder de controle em aliená-lo ao adquirente, o que, por si só, inviabiliza a ideia da tomada de controle, que é entendida como operação potencialmente realizada à revelia de acionistas relevantes e/ou administradores ${ }^{77}$.

Eduardo Secchi Munhoz propõe uma escala decrescente de estabilidade e de concentração do poder de controle nas sociedades anônimas, na seguinte ordem: (i) controle totalitário; (ii) controle majoritário; (iii) controle minoritário; (iv) controle gerencial; e (v) controle externo ${ }^{78}$. Endossamos expressamente esta escala, que tem especial importância e aplicação no trabalho ora desenvolvido, tendo em vista o esforço em identificar as companhias mais suscetíveis à tomada de controle e, portanto, mais tendentes a adotarem proteções para que isto não ocorra.

\footnotetext{
${ }^{77}$ Não devem ser descartadas as operações de tomada de controle realizadas amigavelmente e com cooperação de administradores e grupos relevantes de acionistas, concordes com a aquisição do controle pelo ofertante. Na experiência internacional, inúmeros casos de tomadas de controle hostis convertem-se em amigáveis, inclusive pela aplicação das medidas defensivas que estruturam processo negocial com ofertante e, assim, permitem a formação de consenso entre estes e os administradores e/ou grupos relevantes de acionistas.

${ }^{78}$ MUNHOZ, Eduardo Secchi. Empresa Contemporânea e Direito Societário: poder de controle e grupo de sociedades. São Paulo: Juarez de Olivera, 2002, p. 235.
} 
Nesse compasso, é cada vez mais frequente observar que companhias abertas brasileiras já vêm adotando medidas defensivas contra tomadas de controle hostis, sendo que esta postura é observada inclusive por companhias abertas que, por sua composição acionária concentrada, não estão sujeitas à tomada de controle.

\section{5}

\section{A REALidAde Brasileira}

No Brasil, há uma recente e notória febre de inserção nos estatutos sociais de companhias abertas de disposições estatutárias de “proteção à dispersão acionária”, as quais vêm sendo equivocadamente chamadas de poison pills ${ }^{79}$.

Tais “cláusulas de proteção à dispersão acionária”, que serão examinadas em detalhe no item 6.2, vêm sendo adotadas inclusive por companhias abertas submetidas ao controle concentrado e sem perspectivas de serem submetidas a estruturas de dispersão acionária em seu capital.

Modesto Carvalhosa pondera que:

apesar de ainda não vivenciarmos um mercado de aquisições do poder de controle de companhias abertas (market for corporate control), tampouco enfrentarmos constantes ofertas hostis de aquisição de controle de companhias abertas, o fato é que as medidas popularmente conhecidas como poison pills estão presentes nos estatutos sociais de companhias brasileiras $^{80}$.

É importante esclarecer que tais cláusulas estatutárias, erroneamente referidas como poison pills, embora desempenhem a função de dificultar a tomada de controle na

\footnotetext{
${ }^{79}$ BM\&F-Bovespa. Medidas para evitar concentração de controle estão presentes na maioria dos estatutos. Publicado em $\quad 02.06 .2008 . \quad$ Disponível em:

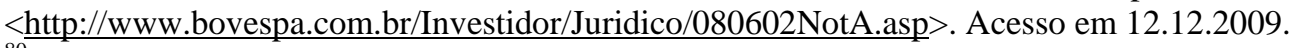

${ }^{80}$ CARVALHOSA, Modesto. As poison pills estatutárias na prática brasileira: alguns aspectos de sua Legalidade. In: CASTRO, Rodrigo R. Monteiro; ARAGÃO, Leandro Santos de. Direito Societário: Desafios Atuais. São Paulo: Quartier Latin, pp. 19-29, 2009, pp. 20-21.
} 
maioria dos casos, não são planos de poison pill clássicos ${ }^{81}$. O “efeito venenoso" das poison pill clássicas é totalmente diferente da consequência inerente às cláusulas estatutárias de proteção à dispersão acionária utilizadas no Brasil.

De um lado, as poison pill clássicas estabelecem que o acionista que ensejou o “disparo” da poison pill estará excluído do plano de direitos atribuíveis aos acionistas, não lhe sendo permitido exercer direitos de aquisição ou subscrição de ações a preços inferiores àqueles praticados pelo mercado. De outro lado, as cláusulas estatutárias de proteção à dispersão acionária estabelecem que o acionista, que adquirir ações em quantidade igual ou superior a determinado percentual de participação acionária, deverá realizar oferta pública para aquisição da totalidade das demais ações de emissão de tal companhia.

A finalidade dessa disposição estatutária é, de certa forma, proteger a companhia contra ofertas hostis, ao tornar demasiadamente oneroso o aumento de participação acionária para além de determinados limites estatutariamente previstos.

A experiência brasileira em matéria de ofertas hostis ainda não é tão fértil, mas, com o grande aumento do número de companhias abertas com dispersão acionária, o Brasil poderá vir a presenciar a ocorrência de fenômenos desta natureza.

Em nosso país, há notícias de pouquíssimas operações de tomada de controle, por meio de oferta pública, com destaque à tentativa de tomada de controle do Sulbanco, realizada pela Macrosul S.A., em $1971^{82}$; e à tentativa de tomada de controle realizada em Outubro de 1978, na oferta pública lançada pela Companhia Força e Luz Cataguazes Leopoldina para a aquisição do controle da Companhia Mineira de Eletricidade, na qual a Companhia Energética de Minas Gerais - CEMIG apresentou oferta concorrente ${ }^{83}{ }_{-}^{84}$.

${ }^{81}$ Francisco Antunes Maciel Müssnich e Fábio Henrique Peres fazem um alerta quanto à utilização inadequada da expressão poison pill no Brasil (MÜSSNICH, Francisco Antunes Maciel; PERES, Fábio Henrique. Administração deve colaborar para o melhor uso das poison pills. Disponível em http://www.bmalaw.com.br/nova internet/arquivos/Artigos/Numero\%2025.pdf>. Acesso em 12.12.2009).

${ }^{82}$ CARVALHOSA, Modesto. Comentários à Lei de Sociedades Anônimas. v. 4, t. II, 2. ed. rev. e atual. São Paulo: Saraiva, 2003, p. 201.

${ }^{83}$ Para maiores informações, refira-se ao artigo no qual Luiz Leonardo Cantidiano expõe que a CEMIG apresentou uma oferta concorrente sem observar os requisitos exigidos, manifestando publicamente intenção de adquirir ações da Mineira, em quantidade que lhe assegurasse o controle em relação a esta última. Luiz 
Além destes casos acima, anteriores à década de 1980, há a recente e notória tentativa da Sadia S.A. em adquirir o controle da Perdigão Agroindustrial S.A., à época ${ }^{85}$, sua principal concorrente na fabricação e processamento de alimentos à base de proteína animal; e também a recentíssima tentativa de tomada de controle da GVT (Holding) S.A. (“GVT”) pela Vivendi, com a interferência da Telefônica, por meio da TELESP Telecomunicações de São Paulo S/A. O controle da GVT acabou sendo adquirido pela Vivendi, em operação privada.

Quanto ao caso Sadia e Perdigão, a tentativa de tomada de controle foi perpetrada por meio de oferta pública de aquisição de controle, nos termos do artigo 257 da Lei $\mathrm{n}^{\mathrm{o}}$ 6.404/76. O mercado reagiu positivamente diante de tal tentativa ${ }^{86}$, que obteve grande atenção da mídia e representava sinal de prosperidade econômica, trazendo consigo otimismo.

Leonardo Cantidiano assevera que a CVM demorou a repudiar a oferta irregular realizada pela CEMIG e, consequentemente, poucos acionistas da Mineira se dispuseram a aceitar a oferta formalmente realizada pela Cataguazes (única oferta pública registrada até então). Em seguida, a CEMIG realizou oferta pública formal e passou a travar leilão com a Cataguazes, que em determinado momento viu-se impedida de elevar sua oferta por já tê-lo feito uma vez, a teor do que dispõe o artigo $261, \S 1^{\circ}$, da Lei $n^{\circ} 6.404 / 76$. Luiz Leonardo Cantidiano faz duras críticas à postura adotada pela CVM e aponta erros na disputa pelo controle da Mineira (CANTIDIANO, Luiz Leonardo. A aquisição do controle acionário da Cia. Mineira de Eletricidade: Um Caso Polêmico. In: __ . Direito Societário \& Mercado de Capitais. Rio de Janeiro: Renovar, 1996, pp. 6374). Esclareça-se que, à época, ainda não vigorava o artigo 13, §3º da Instrução CVM no 361/02, segundo o qual "uma vez lançada uma OPA concorrente será lícito tanto ao ofertante inicial quanto ao ofertante concorrente aumentarem o preço de suas ofertas tantas vezes quantas julgarem conveniente, desde que de tal aumento dêem notícia pública, com o mesmo destaque da oferta".

${ }^{84}$ Além dos casos referidos, há notícias também da tomada de controle da CEMIG pela Companhia de Eletricidade de Juiz de Fora e da tomada de controle da Cimento Aratu pela Votorantim, ambas as operações realizadas anteriormente à década de 1980 (CORREA, Cristiane; LETHBRIDGE, Tiago. Por que o negócio do ano não saiu?. Revista Exame. 28.07.2006).

${ }^{85}$ Em 19 de maio de 2009, Sadia e Perdigão divulgaram Fato Relevante ao mercado, comunicando sobre a consolidação de seus negócios no setor de fabricação e processamento de alimentos a base de proteína animal, criando a BRF - Brasil Foods S.A.. Resumidamente, pode-se dizer que tal consolidação dar-se-á com a alteração da denominação social da Perdigão para BRF, acompanhada de reorganização societária na Sadia e incorporação das ações desta última pela BRF (conforme Fato Relevante disponível em $<$ www.cvm.gov.br>. Acesso em 12.12.2009).

${ }^{86}$ Sobre a impressão do mercado acionário brasileiro em relação ao caso Sadia $v$. Perdigão, veja-se exemplificativamente: (i) Revista Capital Aberto (Especial). As Melhores Companhias para os Acionistas. São Paulo, dez. 2006, veiculando a matéria "Alinhadas com as melhores práticas"; (ii) LUQUET, Mara. Caso Sadia-Perdigão é sinal de evolução do mercado. Jornal Valor Econômico. 24.07.2006. 
Em breve resumo dos fatos, pode-se relatar a tentativa de tomada de controle da Perdigão pela Sadia como uma iniciativa desta última visando a se consolidar como líder em seu mercado de atuação, a fim de se fortalecer para a competição internacional ${ }^{87}$.

Em junho de 2006, a Sadia realizou oferta pública aos acionistas da Perdigão, oferecendo R\$ 27,88 por ação, que correspondia à média das cotações de bolsa das ações da Perdigão nos trinta pregões imediatamente anteriores à realização da oferta pública, aplicando-se um ágio de 35\% em tal média obtida. Entretanto, os administradores da Perdigão consideraram o valor ofertado pela Sadia significativamente abaixo do efetivo valor de mercado da Perdigão, reputando o valor proposto abaixo das expectativas de seus acionistas.

À época, os maiores acionistas da Perdigão eram oito fundos de pensão ${ }^{88}$ que, conjuntamente, detinham aproximadamente $49 \%$ do capital votante da Perdigão e adotaram estratégia defensiva destinada a impedir a tomada do controle desta última. Tais fundos de pensão convenceram a acionista WEG Participações S.A. ("WEG”) ${ }^{89}$, que detinha aproximadamente 5,88\% das ações da Perdigão, a rejeitar a proposta realizada pela Sadia. Em seguida, com a adesão da WEG à resistência à tomada de controle da Perdigão empreendida pela Sadia, tais fundos de pensão simplesmente rejeitaram a oferta proposta.

Consequentemente, a Sadia realizou nova investida, aumentando para R 29,00 o valor ofertado por ação. Entretanto, tal valor foi considerado abaixo da exigência legal do artigo 261, $\S 1^{\circ}$ da Lei $n^{\circ} 6.404 / 76$, que determina que uma segunda oferta tenha que ser realizada por valor, ao menos, $5 \%$ superior àquele originalmente proposto.

\footnotetext{
${ }^{87}$ Para maiores informações sobre o caso Sadia v. Perdigão, veja-se: CANTIDIANO, Luiz Leonardo. Análise do caso Sadia X Perdigão: uma tentativa de “take over”. In: CASTRO, Rodrigo R. Monteiro de; ARAGÃO, Leandro Santos de (coord.). Sociedade Anônima: 30 anos da Lei 6.404/76, São Paulo: Quartier Latin, 2007, pp. 221-245.

${ }^{88}$ Caixa de Previdência dos Funcionários do Banco do Brasil - PREVI; Fundação Petrobras de Seguridade Social - PETROS; Fundação de Assistência e Previdência Social do BNDES - FAPES; Caixa de Previdência dos Funcionários do Sistema BANERJ - PREVI; Fundação Sistel de Seguridade Social; Fundação Vale do Rio Doce de Seguridade Social - Valia; Real Grandeza - Fundos de Previdência e Assistência Social; e PSPP - Perdigão Sociedade de Previdência Privada.

${ }^{89}$ Destaque-se que os fundos de pensão detinham expressiva participação acionária na WEG S.A.
} 
Como resultado final, os fundos de pensão com o suporte da WEG, reunindo aproximadamente 55,5\% do capital social votante da Perdigão, rejeitaram a oferta pública proposta pela Sadia ${ }^{90}$.

Observa-se, no caso Sadia v. Perdigão, que a resistência à tentativa de tomada de controle se deu pela coordenação de acionistas expressivos que compunham a dispersão acionária, valendo-se da espécie de medida defensiva que denominamos “fortalecimento da esfera de controle”, que será examinada em detalhe no item 6.19.

No recentíssimo caso GVT v. Vivendi, com interferência da Telefônica, a GVT é uma companhia aberta que, até outubro de 2009, possuía dispersão acionária, sendo que aproximadamente $65 \%$ de seu capital social, total e votante, estavam dispersos no mercado, enquanto seus principais acionistas, detentores de controle minoritário, possuíam aproximadamente 35\% de seu capital social, total e votante.

Durante os meses de agosto e setembro, os acionistas detentores do controle minoritário da GVT e a administração desta última iniciaram negociação com a francesa Vivendi, companhia aberta atuante no setor de telefonia, interessada em ingressar e iniciar operações no Brasil. Em meio a tais negociações, celebrou-se acordo estabelecendo que a Vivendi adquiriria a GVT, mediante oferta pública de aquisição de ações destinada a totalidade do capital da GVT, ao preço de R\$ 42,00 por ação. Os detentores do controle minoritário haviam se comprometido a aceitar a oferta, aderindo à mesma com ações representativas de $20 \%$ a $30 \%$ do capital da GVT. O restante seria adquirido pela Vivendi diretamente do mercado.

Alguns dias após o anúncio de que a oferta pública de aquisição de ações seria realizada, a espanhola Telefônica, por meio da TELESP - Telecomunicações de São Paulo S/A, divulgou Fato Relevante comunicando ao mercado que realizaria oferta pública para aquisição de ações da GVT, pelo preço de R\$ 48,00 por ação.

Diante de tal cenário, formou-se ambiente de expectativas positivas no mercado, com a Vivendi sinalizando que poderia elevar a oferta e, ao mesmo tempo, a

\footnotetext{
${ }^{90} \mathrm{O}$ resultado final da tentativa de tomada de controle no caso Sadia v. Perdigão instigou a análise da mídia, dos agentes econômicos e do mercado em geral. Exemplificativamente, referir-se a CORREA, Cristiane; LETHBRIDGE, Tiago. Por que o negócio do ano não saiu?. Revista Exame. 28.07.2006.
} 
Telefônica manifestando interesse em cobrir tal proposta. Em observância ao artigo 261, $\S 1^{\circ}$, da Lei no 6.404/76, que exige elevação de no mínimo 5\% do valor da oferta, em meio às ofertas concorrentes, esperava-se que a próxima oferta seria feita por aproximadamente R\$ 50,50 e, em seguida, por R\$ 53,00.

Nos bastidores, ao invés de realizar oferta pública destinada ao mercado, a Vivendi adquiriu, em operação privada, aproximadamente $29,9 \%$ da participação dos acionistas detentores do controle minoritário da GVT e ainda adquiriu 8\% perante acionistas relevantes desta última e opção de compra de 19,6\% do capital, votante e total, da GVT. Desta forma, a Vivendi tornou-se titular de aproximadamente 37,9\% do capital, votante e total, da GVT e, após o exercício das opções de compra recém-adquiridas tornarse-ia titular de $57,5 \%$ do capital, votante e total, da GVT.

Em observância às disposições do artigo 254-A da Lei nº 6.404/76, a Vivendi apresentará oferta pública obrigatória aos demais acionistas da GVT, ao valor de R\$56,00. A operação foi recebida com otimismo pelo mercado de capitais brasileiro, ao mesmo tempo em que despertava receios no setor de telefonia com o ingresso de um novo competidor $^{91}$.

Embora as ofertas públicas de aquisição de controle ainda não sejam frequentes no Brasil, pode-se ponderar que a sua disseminação poderá originar, em nosso país, um mercado de disputa por controle acionário (market for corporate control), capaz de promover liquidez ainda maior ao nosso mercado de capitais ${ }^{92}$.

\footnotetext{
${ }^{91}$ Para detalhes a respeito, referir-se a ATTUCH, Leonardo; GANOIS, Gustavo. O Plano da Vivendi no Brasil: ele nem chegou e já está assustando os concorrentes. Isto É Dinheiro. São Paulo: Editora Três, n. 633, 25.11.2009, pp. 56-61.

${ }^{9} \mathrm{O}$ mercado acionário brasileiro reagiu positivamente à tentativa de tomada de controle da Sadia em relação à Perdigão. Exemplo disto é a Carta Dynamo nº 51 (Publicação da Dynamo Administração de Recursos Ltda. - $3^{\text {o }}$ Trimestre de 2006. Disponível em <www.dynamo.com.br $>$. Acesso em 12.12.2009). Em tal publicação, há menção de que "em meio a um ciclo bem sucedido de ofertas públicas iniciais, de um movimento favorável de liquidez e valorização nas ações e de uma crescente adesão voluntária de novas companhias aos melhores padrões de governança corporativa da BM\&F-Bovespa, a notícia de uma operação de troca de controle no mercado, independentemente de seus desdobramentos, foi recebida como mais uma boa nova em tempos de transformação”.
} 


\section{AQUISIÇÃO OU OBTENÇÃO DO PODER DE CONTROLE}

Conforme examinado acima, o poder de controle não é estático e está suscetível a alterações. A aquisição ou obtenção do poder de controle pode ocorrer por meio de diversas maneiras, as quais podem se dar de forma voluntária ou involuntária; originária ou derivada; originada de uma operação isolada ou de operações coordenadas em conjunto; e amigável ou hostil.

Há inúmeros métodos disponíveis para a aquisição ou obtenção do poder de controle, dentre os quais destacamos: (i) a compra e venda negociada de ações em número suficiente para assegurar o controle em relação à companhia; (ii) a escalada acionária; (iii) a cessão do controle externo; (iv) a subscrição de ações; (v) os contratos de organização do controle; e (vi) a oferta pública de aquisição de controle.

Neste trabalho, à luz dos objetivos a serem alcançados com a classificação das modalidades de aquisição ou obtenção do poder de controle, a análise restringir-se-á às seguintes distinções:

\subsubsection{VOLUNTÁRIA OU INVOLUNTÁRIA}

O elemento distintivo básico, nesta forma de classificação das aquisições de controle, refere-se à manifestação de vontade para impulsionar os atos direcionados à aquisição do controle de companhia. Em curtos termos, e conforme já se pode antever pelo nome, a aquisição voluntária tem como força propulsora a vontade e não outros atos externos, como ocorre na aquisição dita involuntária. 
Diz-se que as aquisições de controle são voluntárias quando determinadas e caracterizadas pela manifestação volitiva do adquirente em tomar para si o poder de controle de determinada companhia. Diferentemente, as aquisições involuntárias têm lugar nas hipóteses em que se dá a aquisição por motivos exteriores à vontade do adquirente, sem que ele tenha agido por meio de manifestação de vontade.

As aquisições involuntárias compreendem variadas hipóteses, com destaque para a mais flagrante delas, que é a decorrente de sucessão causa mortis, em que o adquirente do poder de controle assume o status socci de controlador por conta de efeitos sucessórios.

Outra hipótese a considerar diz respeito aos casos em que o poder de controle é assumido em decorrência da extinção de direitos reais, tais como usufruto ou fideicomisso, que gravavam as ações de emissão da companhia detidas pelo adquirente do poder de controle. Pode-se conceber, a propósito, situação hipotética em que determinado acionista detém quantidade de ações votantes de certa companhia que, em condições normais, conceder-lhe-iam a posição de acionista controlador. Contudo, por estarem gravadas com usufruto, o exercício dos direitos políticos que acompanham as ações, inclusive o direito de voto, estaria nas mãos do terceiro usufrutuário. Desfeito o usufruto sobre as ações, por circunstâncias alheias à vontade do nu-proprietário, este último passará à condição de controlador da companhia, de forma involuntária.

Guilherme Döring Cunha Pereira prevê, ainda, a hipótese em que o titular do poder de controle em determinada companhia desfaz-se das ações que possui “pulverizando-as” no mercado acionário. Neste caso, determinado acionista que detivesse participação acionária expressiva na sociedade, porém, em montante insuficiente para assumir a condição de controlador, ver-se-ia alçado à condição de potencial controlador, ainda que sob o regime do controle minoritário ${ }^{93}$.

Por sua vez, a aquisição voluntária de controle pode ocorrer, dentre outras hipóteses, na compra e venda de ações mediante contrato celebrado entre vendedor e comprador; na oferta púbica de aquisição de ações; e nas operações de reorganização

\footnotetext{
${ }^{93}$ PEREIRA, Guilherme Döring Cunha. Alienação do Poder de Controle Acionário. São Paulo: Saraiva, 1995, p. 32.
} 
societária, em que o adquirente volitivamente coordena atos que lhe assegurarão a obtenção do poder de controle sobre a companhia.

\subsubsection{ORIGINÁRIA OU DERIVADA}

Na classificação da aquisição em originária ou derivada, a distinção dá-se, fundamentalmente, com base em um critério de causalidade. Em outras palavras, a aquisição é originária quando não há nenhuma ligação causal entre a perda ou diminuição de um direito e a aquisição deste por outrem, ou, nas palavras de Pontes de Miranda, “se o suporte fático do fato jurídico, de que nasce direito, pretensão, ação ou exceção, é sem ligação com outro fato jurídico" 94 . Inversamente, a aquisição derivada caracteriza-se pela existência ou extensão de um direito ou de uma relação prévia entre precedente e consequente sujeito de direito ${ }^{95}$.

Como se vê, para precisar os limites entre aquisição originária e derivada, importa verificar não somente a existência ou não de um direito anterior na titularidade de outra pessoa, mas a existência de uma relação causal, na medida em que, nas aquisições originárias, mesmo "quando o direito anterior exista, o direito não foi adquirido por causa desse direito, mas apesar dele" ${ }^{96}$. A aquisição derivada pressupõe a transferência de bloco de ações, pré-existente, assegurando o exercício do poder de controle ao antigo titular.

Na aquisição originária, a propriedade do bem se constitui de forma inicial e/ou original no patrimônio do adquirente, desvinculada de qualquer relação com titular anterior, sem relação jurídica de transmissão. A aquisição originária do poder de controle

\footnotetext{
${ }^{94}$ PONTES DE MIRANDA, Francisco Cavalcanti. Tratado de Direito Privado. t. V, Campinas: Bookseller, 2000, p. 45.

${ }^{95}$ Neste sentido, veja-se, a título de exemplo, GOMES, Orlando. Direitos Reais. 17. ed. Atualizada por Humberto Theodoro Júnior. Rio de Janeiro: Forense, 2000, p. 137.

${ }^{96}$ PINTO, Carlos Alberto da Mota. Teoria Geral do Direito Civil. 4. ed. Atualizada por António Pinto Monteiro e Paulo Mota Pinto. Coimbra: Coimbra Editora, 2005, p. 359, grifo do autor. Neste mesmo sentido: "Na aquisição derivativa, - do direito de outrem, sendo, como é, causa, depende o do adquirente. Na aquisição originária, ainda que haja, antes, esse direito de outrem, o do adquirente não depende dele. É, a despeito daquele, em vez de ser devido a ele” (PONTES DE MIRANDA, Francisco Cavalcanti. Op. cit., p. 56).
} 
dá-se não com a transferência da titularidade do bloco de controle, mas sim com a formação do bloco de controle pelo adquirente do controle.

Nas aquisições derivadas, por conta da dependência em relação a um direito ou relação anterior, o adquirente compra as ações da companhia nas mesmas condições em que tais bens se encontravam no patrimônio do alienante. Vige aqui a regra segundo a qual ninguém pode transmitir mais direitos do que tem. Portanto, caso as ações estejam pendentes de integralização ou gravadas com certo ônus e/ou gravame, o adquirente assumirá a propriedade deste bem com os mesmos atributos e limitações de que se revestia nas mãos do antecessor.

A relevância prática da distinção diz respeito aos efeitos produzidos conforme seja a aquisição originária ou derivada. Isto porque, como vimos, o modo derivado implica a transferência do direito (no caso, das ações) com as mesmas características e restrições que possuía no patrimônio do antecessor, ao passo que, na aquisição originária, as ações incorporam-se ao patrimônio do adquirente de forma plena, sem qualquer condicionamento a uma relação ou situação prévia.

Sob esta perspectiva, a diferenciação básica em relação a esta forma de aquisição do controle relaciona-se ao fato de o controle ser formado originariamente pelo adquirente ou ser adquirido já pré-existente, por meio de operação derivada.

No regime jurídico brasileiro, a distinção entre as aquisições de controle de companhias abertas, sob forma originária ou derivada, revela-se especialmente importante para determinar a aplicação do artigo 254-A da Lei n 6.404/76.

As aquisições derivadas do controle de companhias pressupõem a preexistência de bloco de controle constituído na companhia-alvo, a ser adquirido, nestas condições, pelo adquirente. É importante examinar se houve a transferência do controle, de modo a determinar se há incidência da obrigatoriedade de realização de oferta pública de compra 
das ações pertencentes aos acionistas minoritários, de acordo com o artigo 254-A da Lei ${ }^{\circ}$ $6.404 / 76^{97}$.

As hipóteses clássicas de aquisição derivada são a compra e venda de ações, por meio de contrato entre vendedor e comprador, resultando em transferência de controle; e algumas operações de reestruturação societária ${ }^{98}$.

A aquisição originária de controle pode ocorrer tanto em situações de inexistência de controle acionário definido quanto em situações de controle minoritário e/ou gerencial.

Por fim, as ofertas públicas de aquisição de controle, direcionadas às ações dispersas no mercado, assim como as operações de compra e venda de pequenos lotes de ações em bolsa de valores (escalada acionária), constituem modalidades de aquisição de controle a título originário, uma vez que o bloco de controle se formará apenas com a consolidação de tais operações.

${ }^{97} \mathrm{O}$ artigo 254-A trata da oferta pública obrigatória de aquisição de controle, que é, frise-se expressamente, distinta daquela prevista no artigo 257 da Lei $n^{\circ}$ 6.404/76, em relação às quais se opõem as medidas defensivas, que são o objeto deste estudo. O caput do artigo 254-A estabelece que "a alienação, direta ou indireta, do controle de companhia aberta somente poderá ser contratada sob a condição, suspensiva ou resolutiva, de que o adquirente se obrigue a fazer oferta pública de aquisição das ações com direito a voto de propriedade dos demais acionistas da companhia, de modo a lhes assegurar o preço no mínimo igual a $80 \%$ (oitenta por cento) do valor pago por ação com direito a voto, integrante do bloco de controle”. O bloco de controle, por sua vez, consiste no conjunto de ações que está sendo usado, pelo acionista ou grupo de acionistas, para assegurar, de modo permanente, a preponderância de sua vontade na vida societária. $\mathrm{O} \S 1^{\circ}$ do artigo 254-A determina que sejam entendidas como "alienação de controle a transferência, de forma direta ou indireta, de ações integrantes do bloco de controle, de ações vinculadas a acordos de acionistas e de valores mobiliários conversíveis em ações com direito a voto, cessão de direitos de subscrição de ações e de outros títulos ou direitos relativos a valores mobiliários conversíveis em ações que venham a resultar na alienação de controle acionário da sociedade”.

${ }^{98}$ A CVM tem firmado entendimento pela inaplicabilidade do artigo 254-A da Lei $\mathrm{n}^{\circ}$ 6.404/76 às transferências de controle resultantes de operações de incorporação e de incorporação de ações. Neste sentido, refira-se à associação entre Petróleo Brasileiro S.A. (Petrobras) e União de Indústrias Petroquímicas S.A. (Unipar), que alterou o controle da Suzano Petroquímica S.A. (CVM, Processo Administrativo RJ-20084156, Rel. Dir. Sergio Weguelin, j. 17.06.2008), tendo servido de fundamento para que a Superintendência de Registro (SRE) da CVM se manifestasse a respeito da inaplicabilidade do artigo 254-A da Lei n ${ }^{\circ}$ 6.404/76 nas operações Datasul/Totvs (CVM, Processo Administrativo RJ-2008-7849), Tenda/Gafisa e Company/Brascan (CVM, Memorando 214/2008, Superintendência de Registro de Valores Mobiliários SRE, Gerência de Registros 1 - GER-1, 19.09.2008. Para maiores informações, confira-se, ainda: BELOCH, Henrique Vargas. CVM afasta Tag Along em Operações de Incorporação. Disponível em

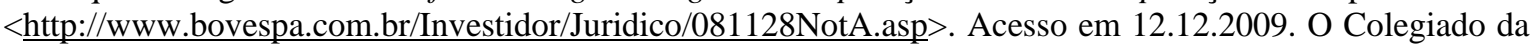
CVM tem entendido que "[a] incorporação não é uma alienação de controle e, salvo nos casos de fraude à lei, não dá ensejo à oferta prevista no art. 254-A", conforme Razões de Voto do Diretor Marcos Barbosa Pinto, em relação à incorporação da Duratex S.A. pela Satipel Industrial S.A. (CVM, Processo Administrativo RJ2009-5811, Rel. Superintendência de Relações com Empresas - SEP, j. 28.07.2009). 


\subsubsection{DECORRENTE DE OPERAÇÃO ISOLADA OU DE OPERAÇÕES CONJUNTAS}

A aquisição do controle pode decorrer de: (i) uma única e isolada operação, que, de forma individual, seja capaz de resultar na aquisição do controle da companhiaalvo; ou (ii) uma série de operações coordenadas que, quando analisadas conjuntamente, terão gerado o efeito da aquisição do controle da companhia-alvo.

Os métodos clássicos de aquisição de controle por uma única e isolada operação são a compra e venda de ações, mediante celebração de contrato, em quantidade suficiente para assegurar o controle da companhia-alvo, e a oferta pública de aquisição de controle.

Em relação à aquisição de controle resultante de uma série de operações coordenadas, em regra, o método clássico é a realização de compras progressivas de pequenas quantidades de ações de emissão da companhia-alvo, por meio de operações em bolsa de valores, até atingir o percentual de ações necessário para assegurar o controle em relação à companhia. Esta modalidade de aquisição de controle é referida como "escalada acionária” e será examinada no item 3.2.2.

\subsubsection{AMIGÁvel OU HoSTIL}

As aquisições de controle consideradas amigáveis são aquelas realizadas com o consentimento dos administradores e/ou de determinados acionistas e/ou grupos de acionistas relevantes da companhia-alvo e, em alguns casos, conduzidas em atendimento à solicitação destes. Na maioria dos casos em que a aquisição do controle é realizada de forma amigável, a mesma será concretizada por meio de negociações que resultarão na celebração de contrato de compra e venda de ações, em quantidade capaz de assegurar o controle ao adquirente. Todavia, não se devem excluir as ofertas públicas de aquisição de ações como mecanismo realizado também nos casos de operações amigáveis. 
Quando há resistência por parte da administração e/ou de determinados grupos de acionistas relevantes da companhia-alvo para negociar uma aquisição amigável e, ainda assim, o terceiro interessado em adquirir o controle da companhia-alvo mantém este propósito, as aquisições de controle são consideradas hostis.

As ofertas públicas de aquisição de controle desempenham eficientemente o papel de mecanismo para a aquisição do controle de companhias abertas, quando a administração e/ou acionistas da companhia-alvo não se dispõem a negociar a aquisição por meio dos métodos consensuais.

Ao contrário dos métodos frequentes de aquisição do controle de companhias $^{99}$, as ofertas públicas podem ser realizadas pelo ofertante diretamente aos acionistas da companhia-alvo, em regra, sem a interferência da administração da companhia-alvo.

Os investidores de mercado detentores de ações de emissão da companhia-alvo poderão aceitar a oferta pública realizada pelo ofertante e, neste caso, se a quantidade de ações envolvida na operação for capaz de permitir que o terceiro interessado adquira o controle da companhia-alvo, a aquisição será concretizada.

As aquisições de controle realizadas de forma hostil integram o tema central deste trabalho, pois são justamente como proteção contra estas que se colocam as medidas defensivas à tomada de controle.

É importante esclarecer que nada impede que ofertas públicas inicialmente hostis convertam-se em amigáveis, sendo concluídas sob esta perspectiva. As medidas defensivas podem, inclusive, desempenhar importante papel nesta mudança de concepção, ao obrigarem o ofertante a negociar a tomada de controle com a administração da companhia-alvo, propiciando meios para que a hostilidade seja superada com concessões mútuas entre o ofertante e a administração da companhia-alvo, que coordenará a defesa pela pluralidade de seus acionistas.

\footnotetext{
${ }^{99}$ Como, por exemplo, a compra e venda de ações do controlador e operações de reorganização societária que tenham como efeito a aquisição de controle.
} 
Há inúmeros métodos disponíveis para a aquisição ou obtenção do poder de controle em companhias, mas, à luz do tema central deste estudo, serão analisados brevemente apenas alguns dos métodos utilizados com maior frequência.

\subsubsection{COMPRA E VENDA Negociada de Ações do CONTROLE}

A compra e venda negociada de ações representativas do controle de determinada companhia é o método clássico por meio do qual são realizadas as operações de aquisição do poder de controle. Determinados acionistas de certa companhia aberta, que estejam interessados em alienar suas ações, formalizam, em operação privada, negócio jurídico bilateral de compra e venda com acionistas desta mesma companhia e/ou com terceiros, que adquirem ações em quantidade suficiente para assegurar-lhes o controle da companhia.

A aquisição de controle da companhia-alvo realizada de forma amigável, tradicionalmente, é realizada mediante celebração de contrato de compra e venda de ações entre vendedor(es) e comprador(es). O interessado deverá iniciar uma negociação direta com o acionista ou grupo de acionistas titular do poder de controle visando à aquisição das ações de sua propriedade, celebrando-se o contrato de compra e venda, uma vez aceitos os termos e condições da operação. A transferência da titularidade das ações operar-se-á nos livros societários da companhia ou por meio dos registros mantidos pela instituição financeira responsável pela escrituração das ações de emissão da companhia. Roberta Nioac Prado, com precisão conceitual, refere-se a esta técnica de aquisição de controle como “cessão privada de controle”, alertando que "a principal vantagem para o adquirente 
do controle fazê-lo por meio de cessão privada fundamentalmente consiste na segurança de alcançar o controle efetivo da companhia em curto espaço de tempo”100.

Por outro lado, tal método de aquisição de controle suscita grande desvantagem ao adquirente do controle, no que concerne ao custo da operação. Roberta Nioac Prado pondera que este efeito do custo da operação decorre:

[e]m primeiro lugar, em razão do prêmio pelo controle que geralmente será pedido pelo alienante. Em segundo lugar, em face do custo não estimado que advirá de tal operação, nos países em que a OPA $a$ posteriori é obrigatória por lei, tal qual no Brasil segundo o art. 254-A da LSA de $1976^{101}$.

Embora a compra e venda negociada de ações representativas do controle seja o método mais frequente de aquisição de controle no Brasil, nas hipóteses em que os acionistas da companhia-alvo, detentores das ações representativas do controle, não se predispõem a negociar a compra e venda destas ações, a operação torna-se inviável.

\subsubsection{EscAladA ACIONÁRIA}

A escalada acionária ${ }^{102}$ caracteriza-se pela aquisição progressiva de pequenos lotes de ações em bolsa de valores, até que o adquirente reúna, sob sua propriedade, ações em quantidade suficiente para obter o poder de controle ${ }^{103}$.

\footnotetext{
${ }^{100}$ PRADO, Roberta Nioac. Oferta Pública de Ações Obrigatória nas S.A.: Tag Along. São Paulo: Quartier Latin, 2005, p. 77.

${ }^{101}$ Ibid., p. 77.

${ }^{102}$ A expressão "escalada acionária” é adotada em referência ao aumento gradual da participação detida pelo acionista interessado no poder de controle. Consiste na compra e venda de pequenas quantidades de ações (subida gradual) até que o acionista adquira o poder de controle (cume da montanha). A doutrina norteamericana usualmente refere-se a esta forma de aquisição de controle como creeping control.

${ }^{103} \mathrm{~A}$ escalada acionária não é inédita no Brasil, tendo como exemplo a tomada de controle da Cervejaria Brahma ocorrida em 1989, por iniciativa do Banco Garantia, liderado por Jorge Paulo Lemann, Marcel Herman Telles e Carlos Alberto Sicupira (cf. BARROS, Guilherme de. Jornal Folha de São Paulo, 15.07.2008. Apud AZEVEDO, Luis André Negrelli de Moura. A oferta pública para aquisição de controle
} 
Roberta Nioac Prado define a escalada acionária como:

mecanismo de aquisição de controle societário, que consiste na aquisição progressiva, em Bolsa de Valores (mercado secundário) e, eventualmente, em contratações privadas com acionistas minoritários, de participações acionárias votantes de emissão da companhia aberta cujo controle se pretende adquirir, pela pessoa, ou grupo de pessoas, físicas ou jurídicas, até que esta(s) adquira(m) número suficiente de ações com direito a voto para efetivamente exercer o controle desta companhia aberta ${ }^{104}$.

A aquisição do controle da companhia-alvo, por meio de uma série de operações coordenadas, é realizada quando o adquirente interessado visa a surpreender os acionistas e os administradores da companhia-alvo e, quiçá, o próprio mercado em geral, em relação ao objetivo de tomar o controle da companhia-alvo.

Entretanto, esse método suscita inconvenientes que tendem a inviabilizar a tomada de controle. Sempre há a possibilidade de que as operações individuais para a aquisição de pequenas quantidades de ações de emissão da companhia-alvo sofram interferências externas de terceiros igualmente interessados na compra das ações de emissão da companhia-alvo. Consequentemente, não há previsibilidade de que o adquirente interessado efetivamente adquirirá em bolsa de valores a quantidade de ações que pretende comprar.

Além disso, em decorrência das investidas realizadas pelo adquirente interessado, há tendência natural à elevação das cotações em bolsa de valores das ações de emissão da companhia-alvo. Isto é, por conta do aumento da procura por ações da companhia-alvo, a aquisição do controle poderá tornar-se mais custosa ou, até mesmo, injustificável do ponto de vista financeiro.

Outra desvantagem inerente à escalada acionária, como mecanismo destinado à tomada de controle, é a tendência de que a aquisição de ações em quantidade capaz de

sob a perspectiva da companhia aberta ofertante. In: CASTRO, Rodrigo R. Monteiro de; ARAGÃO, Leandro Santos de (coord.). Direito Societário: Desafios Atuais. São Paulo: Quartier Latin, 2009, p. 85).

${ }^{104}$ PRADO, Roberta Nioac. Oferta Pública de Ações Obrigatória nas S.A.: Tag Along. São Paulo: Quartier Latin, 2005, p. 70. 
assegurar o controle ao adquirente consuma mais tempo para ser concluída, do que aquele necessário aos demais métodos de tomada de controle.

Guilherme Döring Cunha Pereira pondera que:

muitas legislações têm tomado medidas que restringem o fator surpresa, o que se obtém, por exemplo, impondo ao adquirente de certas porcentagens de ações, normalmente não muito elevadas (5, 10 ou 15\%), a obrigatoriedade de declarar à sociedade emissora ou aos agentes de mercado a aquisição feita ${ }^{105}$.

No Brasil, o artigo 12 da Instrução CVM n ${ }^{0} 358 / 02^{106}$ exige que qualquer pessoa ou grupo de pessoas, agindo conjuntamente, que atingir participação, direta ou indireta, correspondente a 5\% ou mais de espécie ou classe de ações representativas do capital de companhia aberta, deve enviar declaração à $\mathrm{CVM}^{107}$ e, se for o caso, à bolsa de valores e entidade do mercado de balcão organizado em que os valores mobiliários de emissão da companhia sejam admitidos à negociação.

O $\S 1^{\circ}$ do artigo 12 da Instrução CVM n ${ }^{0}$ 358/02 estabelece, ainda, que está igualmente obrigada à divulgação das mesmas informações a pessoa ou grupo de pessoas

105 PEREIRA, Guilherme Döring Cunha. Alienação do Poder de Controle Acionário. São Paulo: Saraiva, 1995, p. 32.

${ }^{106}$ Esta é a dicção do artigo 12 da Instrução CVM n ${ }^{\circ}$ 358/02: “Os acionistas controladores, diretos ou indiretos, e os acionistas que elegerem membros do Conselho de Administração, bem como qualquer pessoa natural ou jurídica, ou grupo de pessoas, agindo em conjunto ou representando um mesmo interesse, que atingir participação, direta ou indireta, que corresponda a 5\% (cinco por cento) ou mais de espécie ou classe de ações representativas do capital de companhia aberta, deve enviar à CVM e, se for o caso, à bolsa de valores e entidade do mercado de balcão organizado em que os valores mobiliários de emissão da companhia sejam admitidos à negociação, assim como divulgar, nos termos do art. $3^{\circ}$, declaração contendo as seguintes informações: (i) nome e qualificação do adquirente, indicando o número de inscrição no Cadastro Nacional de Pessoas Jurídicas ou no Cadastro de Pessoas Físicas; (ii) objetivo da participação e quantidade visada; (iii) número de ações, bônus de subscrição, bem como de direitos de subscrição de ações e de opções de compra de ações, por espécie e classe, já detidos, direta ou indiretamente, pelo adquirente ou pessoa a ele ligada; (iv) número de debêntures conversíveis em ações, já detidas, direta ou indiretamente, pelo adquirente ou pessoa a ele ligada, explicitando a quantidade de ações objeto da possível conversão, por espécie e classe; e (v) indicação de qualquer acordo ou contrato regulando o exercício do direito de voto ou a compra e venda de valores mobiliários de emissão da companhia”.

${ }^{107}$ A CVM poderá autorizar a dispensa da divulgação pela imprensa, em face do grau de dispersão das ações da companhia no mercado, e da declaração do adquirente de que suas compras não objetivam alterar a composição do controle ou a estrutura administrativa da sociedade, desde que assegurada a efetiva publicidade por meio de divulgação julgada satisfatória pela CVM (§5º artigo 12 da Instrução CVM $n^{\circ}$ 358/02). 
representando um mesmo interesse, titular de participação acionária igual ou superior a 5\% ou mais de determinada espécie ou classe de ações representativas do capital de companhia aberta, a cada vez que a referida participação se eleve em 5\%.

O dever de informar estabelecido no caput e no $\S 1^{\circ}$ do artigo 12 da Instrução $\mathrm{CVM} \mathrm{n}^{\circ}$ 358/02 se estende também à aquisição de quaisquer direitos sobre as ações e demais valores mobiliários, tal como prevê o $\S 2^{\circ}$ do artigo 12 da Instrução CVM n ${ }^{\circ}$ 358/02.

Além dessa obrigação de informar, aplicável a qualquer indivíduo que assuma e/ou eleve sua participação em 5\% ou mais de determinada espécie ou classe de ações representativas do capital de companhia aberta, o $\S 6^{\circ}$ do artigo $4^{\circ}$ da Lei ${ }^{0}$ 6.404/76 estabelece que “o acionista controlador ou a sociedade controladora que adquirir ações da companhia aberta sob seu controle que elevem sua participação, direta ou indireta, em determinada espécie e classe de ações a porcentagem que, segundo normas gerais expedidas pela Comissão de Valores Mobiliários, impeça a liquidez de mercado das ações remanescentes, será obrigado a fazer oferta pública, por preço determinado nos termos do §4º̄, para aquisição da totalidade das ações remanescentes no mercado”.

Na hipótese de a aquisição gradual ser realizada por acionista controlador, este estará obrigado a realizar a chamada oferta pública por aumento de participação, que constitui modalidade de oferta pública obrigatória, realizada em consequência do aumento da participação do acionista controlador no capital social de companhia aberta, nos termos do artigo $4^{\circ}$, $\S 6^{\circ}$, da Lei ${ }^{\circ} 6.404 / 76$ e do artigo $2^{\circ}$ da Instrução CVM nº 361/02.

A obrigatoriedade de realização de oferta pública por aumento de participação tem por objetivo evitar o chamado "fechamento branco de capital”, verificado quando, em decorrência de aquisições feitas pelo acionista controlador (ou por quem está vinculado a ele, sob alguma forma), reduz-se o nível de liquidez das ações em circulação no mercado, deixando o investidor em situação desfavorável. Luiz Leonardo Cantidiano doutrina que:

[...] como resultado do estreitamento da liquidez, as cotações das ações se deprimem, dificultando a realização de eventual alienação pretendida pelo minoritário, até mesmo pela inexistência de compradores, que não se 
sentem estimulados a investir suas poupanças na aquisição de ações que não dispõem de suficiente liquidez ${ }^{108}$.

A proteção legal visa a impedir que os acionistas minoritários, ao estarem desprovidos de liquidez, tornem-se suscetíveis a operações desvantajosas realizadas com o acionista controlador, que, potencialmente, será o único interessado na aquisição destas ações. Nas palavras de Luiz Gastão Paes de Barros Leães:

[...] adquirindo posição significativa no mercado das ações da controlada, o controlador reduz o nível de liquidez das ações detidas pelos minoritários, na medida em que deprime a cotação das mesmas no mercado, aparecendo como o único comprador do papel ${ }^{109}$.

Em sentido semelhante, alertando para os riscos de o acionista controlador tornar-se o único interessado nas ações de emissão da companhia, em situações de “fechamento branco”, Luiz Leonardo Cantidiano explica que são comuns os casos em que:

[...] configurada a situação de falta de liquidez da ação, o acionista controlador apresentava oferta pública para o cancelamento formal de registro, propondo o pagamento de um pequeno ágio em relação aos preços esporadicamente praticados no mercado; como o investidor não tinha escolha, acabava aceitando a oferta, porque via na proposta que lhe era dirigida a única alternativa possível de recuperar o valor de seu investimento $^{110}$.

O artigo $4^{\circ}, \S 6^{\circ}$, da Lei $n^{0}$ 6.404/76, com redação atribuída pela Lei $n^{o}$ 10.303/01, visando a fortalecer direitos de acionistas minoritários, confere expressamente à CVM competência para expedir normas gerais sobre os percentuais que repute sejam capazes de impedir a liquidez de mercado das ações remanescentes com investidores, em seguida a movimentos de aumento de participação por acionista controlador.

\footnotetext{
${ }^{108}$ CANTIDIANO, Luiz Leonardo. Aquisição compulsória de ações. In: Reforma da Lei das S.A. Rio de Janeiro: Renovar, 2002, pp. 55-60.

${ }^{109}$ LEÃES, Luiz Gastão Paes de Barros. Incorporação de ações de companhia aberta controlada. In: Pareceres. v. 2, São Paulo: Singular, 2004, p. 1410.

${ }^{110}$ CANTIDIANO, Luiz Leonardo. Op. cit., pp. 55-60.
} 
A CVM fixou patamar indicativo de redução relevante da dispersão, a que se refere o citado $\S 6^{\circ}$ do artigo $4^{\circ}$ da Lei $n^{\circ}$ 6.404/76, por meio da Instrução CVM no 361/02. O artigo 26 da Instrução CVM n $361 / 02$ refere-se ao percentual mínimo de dispersão de até um terço “do total de cada espécie ou classe em circulação” na data da entrada em vigor da referida instrução ${ }^{111}$.

Além das normas editadas pela CVM, destacam-se também as regras próprias da BM\&F-Bovespa em relação aos percentuais mínimos de liquidez das companhias listadas em segmentos especiais.

Os Regulamentos do Novo Mercado, do Nível 1 e do Nível 2 da BM\&FBovespa, que são normas de adesão espontânea e de observância obrigatória apenas para as companhias abertas que voluntariamente pretendem aderir a tais segmentos especiais da BM\&F-Bovespa, estabelecem que o percentual mínimo de ações que deve estar em circulação no mercado (free float) deverá corresponder a, pelo menos, 25\% do capital social da companhia.

\section{CESSÃo do CONTROLE EXTERNo}

Conforme examinado no item 2.2.2, o controle externo decorre do exercício do poder de dominação em relação à companhia por alguém que não integra os seus órgãos sociais.

Na maioria dos casos em que há controle externo, o mesmo decorre de alguma dependência de ordem econômica, tecnológica ou decorrente de relações de mercado ${ }^{112}$.

\footnotetext{
111 “Art. 26. A OPA por aumento de participação, conforme prevista no §6º do art. $4^{\circ}$ da Lei 6.404/76, deverá realizar-se sempre que o acionista controlador, pessoa a ele vinculada, e outras pessoas que atuem em conjunto com o acionista controlador ou pessoa a ele vinculada, adquiram, por outro meio que não uma OPA, ações que representem mais de $1 / 3$ (um terço) do total das ações de cada espécie ou classe em circulação na data da entrada em vigor desta Instrução, observado o disposto no $\S \S 1^{\circ}$ e $2^{\circ}$ do art. $37 ”$.

${ }^{112}$ Carlos Celso Orcesi da Costa refere-se à existência de três formas de controle externo, quais sejam: (i) o controle externo financeiro; (ii) o controle externo tecnológico; e (iii) o controle externo comercial. (COSTA, Carlos Celso Orcesi da. Controle externo nas companhias. RDM. São Paulo: Malheiros, n. 144, out./dez. 1981, pp. 70-75, especialmente p. 74).
} 
Há também ocasiões em que o controle externo pode decorrer de influência política exercida por órgãos estatais, que possuem ingerência sobre a companhia, especialmente quando esta desenvolva atividades de interesse público.

Em regra, a relação de influência exercida pelo agente externo forma-se originariamente, por contratos e relações jurídicas que estabeleçam esta situação de dependência e sujeição da companhia ao domínio externo. Entretanto, pode-se pensar em hipóteses em que o controle externo é transferido de um agente externo para outro mediante, por exemplo, cessão de posição em determinado contrato que assegure as bases para o exercício do controle externo. Esta seria uma hipótese de aquisição derivada do controle externo já pré-existente.

\subsubsection{SUBSCRIÇÃo DE AçõES}

A aquisição do controle por subscrição de ações ocorre quando é realizado aumento do capital de certa companhia, sem que os acionistas exerçam o direito de preferência, previsto no artigo 171 da Lei $n^{\circ}$ 6.404/76, e determinado acionista detentor de participação minoritária e/ou terceiro não titular de participação acionária subscreve as ações emitidas, alterando as proporções das participações acionárias na companhia.

A alteração das participações acionárias em decorrência do aumento de capital que não tenha sido subscrito proporcionalmente pelos acionistas da companhia, dependendo do número de ações subscritas na emissão e do número de ações em que anteriormente se dividia o capital social da companhia, pode conduzir o subscritor à condição de controlador.

A esse respeito, é importante esclarecer que a aquisição do controle por meio da subscrição de ações em aumento de capital pressupõe a concordância e anuência dos acionistas em relação à aquisição do controle, uma vez que: (i) os acionistas terão renunciado aos seus respectivos direitos de preferência para a subscrição das ações emitidas em tal aumento de capital, na proporção de suas respectivas participações no 
capital social (artigo 171 da Lei ${ }^{0}$ 6.404/76); e (ii) caso o estatuto social da companhia não contemple autorização de aumento de capital, sem alteração estatutária, na forma do artigo 168 da Lei $n^{0}$ 6.404/76, com delegação de poderes ao Conselho de Administração para autorizar aumentos de capital no limite do capital autorizado previsto nos estatutos sociais, os acionistas terão aprovado este aumento de capital.

Guilherme Döring Cunha Pereira chama atenção ao fato de que:

nos países em que também se conheça de capital autorizado, e onde a dispersão do capital societário permita a existência de controle gerencial, a subscrição de ações é um meio de a administração transferir sozinha o controle, se o capital autorizado à disposição é suficiente para esse efeito $^{113}$.

Concluindo o exame desta modalidade de aquisição de controle, é importante lembrar que os mesmos efeitos produzidos nas operações de subscrição de ações podem ser alcançados na subscrição de valores mobiliários conversíveis em ações, tais como, por exemplo, bônus de subscrição e debêntures conversíveis em ações.

\subsubsection{CONVENÇõES DE Voto}

As convenções de voto são métodos utilizados com grande frequência na aquisição e organização do poder de controle de companhias. Embora não sejam os únicos instrumentos contratuais disponíveis para a estruturação de convenções de voto, os acordos de acionistas são, notadamente, o principal mecanismo utilizado para este propósito.

Há reconhecidamente três grandes esferas em que se estabelecem convenções de voto, distinguindo-se aquelas estabelecidas: (i) entre acionistas; (ii) entre acionistas e terceiros estranhos à companhia; e (iii) entre acionistas e a própria companhia e/ou seus

${ }^{113}$ PEREIRA, Guilherme Döring Cunha. Alienação do Poder de Controle Acionário. São Paulo: Saraiva, 1995, p. 41. 
administradores. Abordando exatamente estas três espécies de convenções de voto, Fábio Konder Comparato doutrina que as primeiras são as mais comuns, as segundas "pode[m] ter por objeto a organização do controle externo" 114 e as terceiras são “consideradas ilícitas” ${ }^{115}$.

As convenções de voto entre acionistas servem para, dentre outros fins, estabilizar estruturas de controle compartilhado ${ }^{116}$, em que a titularidade de direitos de sócio em relação à maioria do capital votante da companhia é detida conjuntamente, por mais de um acionista.

Pelas convenções de voto, acionistas que individualmente não deteriam o controle em relação à companhia podem vir a adquiri-lo com a formalização, por exemplo, de um acordo de acionistas. O artigo 118 da Lei ${ }^{0}$ 6.404/76 dotará a convenção de voto pactuada, por acordo de acionistas, de segurança jurídica necessária para o cumprimento da avença desejada pelas partes.

Quanto às convenções de voto entre acionistas e terceiros estranhos à companhia, Fábio Konder Comparato opina que o acordo de acionistas também pode servir como instrumento para estabelecer relação jurídica entre acionistas e tais terceiros, em casos de dissociação entre titularidade das ações e direito de voto:

no regime da Lei $\mathrm{n}^{\circ}$ 6.404/76, partes legítimas para celebrar tais convenções são, em princípio, apenas os acionistas. Devemos, no entanto, admitir que nas hipóteses de dissociação entre a titularidade das ações e a do direito de voto - como sucede, por vezes, no usufruto acionário - o usufrutuário pode, legitimamente, figurar como parte no acordo, com os efeitos previstos no art. 118 da lei ${ }^{117}$.

As convenções de voto capazes de alçar acionistas e/ou até mesmo terceiros externos à companhia à condição de controladores não se restringem aos acordos de

\footnotetext{
${ }^{114}$ COMPARATO, Fábio Konder; SALOMÃO FILHO, Calixto. O Poder de Controle na Sociedade Anônima. 4 ed. Rio de Janeiro: Forense, 2005, p. 217.

${ }^{115}$ Ibid., p. 217.

${ }^{116}$ Referidas no item 2.3.1.2 como casos de controle majoritário conjunto.

${ }^{117}$ COMPARATO, Fábio Konder; SALOMÃO FILHO, Calixto. Op. cit., p. 217.
} 
acionistas. No Brasil, assim como em inúmeros outros países de tradição jurídica romanogermânica, há o dogma da inadmissibilidade da separação do direito de voto e da titularidade das ações ${ }^{118}$. Entretanto, esta dissociação é admissível no caso excepcional do usufruto de ações e há ainda previsão de convenção de voto diante da instituição de direitos reais sobre as ações, in casu o próprio usufruto de ações, o penhor de ações e a alienação fiduciária de ações ${ }^{119}$. A própria Lei n ${ }^{0}$ 6.404/76 prevê, nos artigos 113 e 114, a possibilidade de estabelecimento de convenções de voto em tais hipóteses.

O artigo 113 da Lei $n^{\circ}$ 6.404/76 emprega redação relativamente branda no que tange à dissociação do direito de voto, prevendo o caput de tal dispositivo legal que o penhor da ação não impedirá o acionista de exercer o direito de voto, mas será lícito estabelecer que o acionista não poderá votar em certas deliberações, sem o consentimento do credor pignoratício. Já o parágrafo único do mesmo artigo 113 da Lei nº 6.404/76 prevê, em relação à alienação fiduciária, que “o credor garantido por alienação fiduciária da ação não poderá exercer o direito de voto; o devedor somente poderá exercê-lo nos termos do contrato" 120 .

Nota-se que, em ambos os casos, não há propriamente uma dissociação entre o titular das ações e aquele legitimado a exercer o direito de voto, mas um reconhecimento legal de que o conteúdo do voto poderá vir a representar a expressão previamente manifestada pelo credor pignoratício e/ou pelo credor garantido por alienação fiduciária. Esclareça-se, também, que o penhor de ações e a alienação fiduciária são tidos como institutos utilizados pela Lei ${ }^{0}$ 6.404/76 para legitimar o deslocamento da esfera de poder

\footnotetext{
${ }^{118} \mathrm{O}$ artigo 177, §2º , do Código Penal, inclusive, prevê que "incorre na pena de detenção, de seis meses a dois anos, e multa, o acionista que, a fim de obter vantagem para si ou para outrem, negocia o voto nas deliberações de assembléia geral”.

${ }^{119}$ Em relação ao penhor de ações e à alienação fiduciária de ações, embora seja admitida a convenção de voto entre o proprietário da ação e o beneficiário de tal garantia, o proprietário é que permanece legitimado para exercer o direito de voto, a teor do que dispõe o artigo 113 em seu caput e no $\S 1^{\circ}$.

${ }^{120}$ Diante das disposições do artigo 113 da Lei $n^{\circ}$ 6.404/76, Mauro Rodrigues Penteado vai além e aponta que "[...] o art. 113 da lei do anonimato reconhece que, nos termos do contrato, o credor pignoratício das ações e o credor garantido por alienação fiduciária também das ações poderão balizar e mesmo direcionar o exercício do direito de voto pelo acionista devedor, o que suscita a questão de saber se poderão aqueles serem responsabilizados, no caso de abuso de voto perpetrado nessas circunstâncias” (PENTEADO, Mauro Rodrigues. Sociedade Anônima: acionista controlador. RDM. São Paulo: Malheiros, n. 83, pp. 99-115, jul./set. 1991, p. 111).
} 
de dominação exercida em relação à companhia, propiciando meios para a formação de modelos societários de controle externo ${ }^{121}$.

No que tange ao usufruto, a redação do artigo 114 da Lei $n^{\circ}$ 6.404/76 é mais expressa, prevendo que "o direito de voto da ação gravada com usufruto, se não for regulado no ato de constituição do gravame, somente poderá ser exercido mediante prévio acordo entre o proprietário e o usufrutuário”. Pode o instrumento de usufruto estabelecer que o usufrutuário será o titular dos direitos de voto enquanto tal direito real estiver em vigor.

Tudo isto é importante ao entendimento de que as convenções de voto capazes de conduzir alguém à condição de controlador de certa companhia não se restringem aos acordos de acionistas. Fábio Konder Comparato cristalinamente assevera que "pactos parassociais não [são] apenas as clássicas convenções de voto, mas todo e qualquer negócio jurídico contratual, tendente a regular o exercício dos direitos sociais, concluído entre sócios, ou entre sócio e não sócio” ${ }^{122}$. Sendo assim, contratos que estabeleçam penhor de ações, alienação fiduciária e/ou usufruto são igualmente capazes de promover a aquisição de controle por meio de convenção de voto.

\subsubsection{Oferta Pública de Aquisição de Controle}

A oferta pública de aquisição de controle é aquela realizada por ofertante interessado em adquirir ações de emissão de determinada companhia aberta diretamente dos acionistas de tal sociedade, mediante a realização de uma oferta pública, com objetivo de adquirir e/ou consolidar poder de controle em relação a tal companhia, conforme prevê o artigo 257 da Lei ${ }^{\circ} 6.404 / 76$.

A oferta pública de aquisição de controle, por sua importância para este trabalho, será examinada individualmente no capítulo a seguir.

\footnotetext{
${ }^{121}$ Cf. nota de rodapé 62.

122 COMPARATO, Fábio Konder; SALOMÃO FILHO, Calixto. O Poder de Controle na Sociedade Anônima. 4 ed. Rio de Janeiro: Forense, 2005, p. 204.
} 


\section{OFERTA PÚBLICA DE AQUISIÇÃO DE CONTROLE}

\subsection{CONCEITO E GENERALIDADES}

A oferta para aquisição de controle é realizada por ofertante interessado em adquirir ações de emissão de determinada companhia aberta (companhia-alvo) diretamente de seus acionistas, mediante a realização de uma oferta pública, com o objetivo de adquirir e/ou consolidar poder de controle.

Na definição de Alfredo Lamy Filho:

[...] oferta pública para aquisição de controle é negócio unilateral mediante o qual o ofertante faz oferta pública de ações (e não do bloco de controle) em número suficiente para formar o bloco de controle; não há, nessa hipótese, alienação de controle, e sim aquisição originária do controle $^{123}$.

Valendo-nos das categorias de classificação propostas no item 3.1, pode-se estabelecer que a oferta pública de aquisição de ações é uma modalidade de aquisição do poder de controle voluntária, uma vez que pressupõe obrigatoriamente a manifestação de vontade do ofertante; originária, já que o bloco de ações representativas do controle se formará inicial e originalmente a partir da reunião, pelo ofertante, das ações que antes se encontravam dispersas no mercado acionário; e decorrente de operação isolada, isto é, a oferta pública é tendente a adquirir o poder de controle em uma única operação. As ofertas públicas podem ser amigáveis ou hostis, conforme sejam efetuadas com ou sem o consentimento dos administradores e/ou de determinados acionistas e/ou grupos de acionistas relevantes da companhia-alvo.

${ }^{123}$ LAMY FILHO, Alfredo; BULHÕES PEDREIRA, José Luiz. A Lei das S.A. v. 2, 2. ed. Rio de Janeiro: Renovar, 1996, p. 676. 
A experiência norte-americana desenvolveu a figura do raider $^{124}$, que é o ofertante interessado em adquirir o controle de determinada companhia aberta de forma hostil, mediante a realização de oferta pública de aquisição de controle, a fim de modificar a estrutura da gestão, substituindo os membros da administração da companhia-alvo, e muitas vezes buscando a obtenção de lucros imediatos, com a alienação de bens e ativos da companhia-alvo.

Quando há resistência por parte da administração e/ou de determinados grupos de acionistas da companhia-alvo para negociar uma aquisição amigável, as ofertas públicas de aquisição de controle revelam-se como eficiente mecanismo para a tomada hostil do controle.

As ofertas públicas de aquisição de controle pressupõem elevado grau de dispersão das ações de emissão da companhia-alvo e a inexistência de poder de controle definido pela propriedade de ações (i.e., as ofertas públicas de aquisição de controle estão relacionadas às companhias em que não há controle quase totalitário ou controle majoritário) ${ }^{125}$.

Em regra, estão suscetíveis à oferta pública de aquisição de controle as companhias com controle minoritário e gerencial, que, na classificação proposta pelos Regulamentos do Novo Mercado, Nível 1 e Nível 2 da BM\&F-Bovespa, enquadrar-se-iam no conceito do controle difuso.

As ofertas públicas de aquisição de controle visam a permitir ao ofertante reunir ações dispersas entre investidores no mercado em quantidade suficiente para superar

\footnotetext{
${ }^{124}$ Algumas vezes, nota-se que a terminologia hostile raider é utilizada em sentido negativo, como se estes fossem os ofertantes interessados em adquirir o controle de determinada companhia para saqueá-la e expropriá-la de seus bens e ativos. A este respeito, refira-se aos comentários de Erasmo Valladão Azevedo e Novaes França e Mauro Moisés Kertzer, em tradução de conferência de Klaus Hopt (HOPT, Klaus J. Deveres legais e conduta ética de membros do conselho de administração e de profissionais. Tradução de Erasmo Valladão A. e N. França e Mauro Moisés Kertzer. RDM. São Paulo: Malheiros, n. 144, pp. 107-119, out./dez. 2006, p. 117).

${ }^{125}$ Luis André Negrelli de Moura Azevedo pondera no mesmo sentido: “[A] takeover bid somente se justifica em uma companhia submetida ao controle minoritário ou gerencial, o que, por sua vez, pressupõe a dispersão da maioria do capital votante entre diversos acionistas, independentes entre si e não signatários de acordo de controle nos termos do artigo 118 da Lei n ${ }^{\circ}$ 6.404/76" (AZEVEDO, Luis André Negrelli de Moura. A oferta pública para aquisição de controle sob a perspectiva da companhia aberta ofertante. In: CASTRO, Rodrigo R. Monteiro de; ARAGÃO, Leandro Santos de Aragão [coord.]. Direito Societário: Desafios Atuais. São Paulo: Quartier Latin, 2009, p. 85).
} 
o número de ações detidas pelo acionista e/ou grupo de acionistas no exercício do poder de controle, formando-se, assim, bloco representativo da maioria das ações votantes de emissão da companhia.

Tais ofertas destinam-se a todos os titulares de ações com direito a voto da companhia-alvo, em tratamento igualitário ${ }^{126}$, em observância ao princípio da generalidade da oferta (all holders rule) ${ }^{127}$, visando à aquisição de um montante determinado que seja suficiente para assegurar o controle da companhia.

Sobre a igualdade de tratamento aos destinatários da oferta, Fábio Konder Comparato expõe que "para os acionistas destinatários da oferta, a take-over bid garante sempre melhor preço de venda em relação à cotação bolsística e, sobretudo, tratamento rigorosamente igualitário, sem qualquer consideração de ordem pessoal” ${ }^{128}$.

Conforme será examinado a seguir, as ofertas públicas para aquisição de controle surgiram e se desenvolveram como fenômeno econômico de efeitos jurídicos principalmente nos EUA e na Inglaterra, onde são referidas, respectivamente, como tender offers e takeover bids.

A oferta pública de aquisição de controle é uma oferta voluntária, nos termos do artigo $2^{\circ}$, inciso $\mathrm{V}$, da Instrução $\mathrm{CVM} \mathrm{n}{ }^{\circ} 361 / 02$, que não pode ser confundida com as ofertas públicas obrigatórias para aquisição de ações ${ }^{129}{ }^{130}$.

\footnotetext{
${ }^{126}$ Esta característica do "tratamento igualitário" é recorrente quando analisada no direito comparado. Exemplificativamente, em relação à França refira-se a MERLE, Philippe. Droit commercial: sociétés commerciales. 10. ed. Paris: Dalloz, 2005, p. 791; e em relação à Inglaterra, com a análise da relevância do tema no âmbito do Takeover Code londrino, refira-se a CHEFFINS, Brian R. Company Law: theory, structure and operation. Re-imp. 2006. Oxford: Oxford University Press, 1997, pp. 268-269.

${ }^{127}$ O português Paulo Câmara ensina que o "princípio da generalidade da oferta (all holders rule) constitui uma decorrência do caractér público da oferta, vedando qualquer discriminação entre os potenciais destinatários” (CÂMARA, Paulo. O dever de lançamento de oferta pública de aquisição no direito português. In: WARDE Jr., Walfrido Jorge [coord.]. Fusão, Cisão, Incorporação e Temas Correlatos. São Paulo: Quartier Latin, 2009, p. 410).

${ }^{128}$ COMPARATO, Fábio Konder. Aspectos Jurídicos da Macroempresa. São Paulo: RT, 1970, p. 34.

${ }^{129}$ As ofertas voluntárias e as obrigatórias recebem tratamento diferenciado tanto na legislação brasileira quanto na regulamentação da CVM, conforme ensina Vera Helena de Mello Franco (FRANCO, Vera Helena de Mello. Considerações sobre as Ofertas Públicas para Aquisição de Ações (OPAs): Estado Atual da Questão. RDM. São Paulo: Malheiros, n. 144, pp. 16-58, out./dez. 2006, pp. 25-26).

${ }^{130}$ Sobre as principais diferenças entre OPA destinada à aquisição do controle (artigo 257 da Lei no 6.404/76) e aquela realizada em decorrência da alienação do controle (artigo 254-A da Lei $n^{\circ}$ 6.404/65), referir-se a José Alexandre Tavares Guerreiro doutrinando, ainda na vigência da versão anterior do artigo 254 da Lei $\mathrm{n}^{\circ}$
} 
A oferta pública para a aquisição de controle ocorre, com maior frequência, quando o interessado em adquirir ações de emissão da companhia-alvo não tenha tido sucesso ou interesse em negociar amigavelmente com a administração e/ou determinados acionistas ou grupo de acionistas relevantes da companhia.

Nessas hipóteses, quando há resistência à operação, a oferta pública de aquisição revela-se como instrumento eficiente para a realização de aquisições de controle, pois é realizada diretamente aos acionistas detentores de ações dispersas no mercado, independentemente de aprovação de órgãos sociais da companhia-alvo ${ }^{131}$, ao contrário do que ocorre em formas usuais de aquisição de controle.

A hostilidade destas ofertas públicas se refere à administração da companhia e, por vezes, a determinados grupos de acionistas da companhia-alvo, mas não à companhia em si, nem, em princípio, à totalidade de seus acionistas, com relação aos quais se presume amigável a oferta ${ }^{132}$. Nesse sentido, de forma geral, haverá receptividade dos acionistas detentores de ações dispersas no mercado, já que a oferta propiciará meios para a valorização da cotação das ações e oportunidade de negociação das mesmas.

Fran Martins doutrina que:

[a] oferta pública para a aquisição do controle societário tende a favorecer os acionistas minoritários da companhia. Em princípio, a oferta deve partir de uma pessoa ou sociedade que deseja adquirir o controle societário de uma companhia sem entrar em entendimentos prévios com os acionistas majoritários. Haverá, assim, uma oportunidade para que

6.404/76, ensina tratar-se de "modalidade especial de oferta pública, cujo objetivo se diferencia substancialmente daquela regulada no art. 257 da referida lei. Não se tem em mira, aqui, a aquisição de controle, mas a proteção patrimonial dos acionistas minoritários, que não sejam parte no negócio translativo do controle e que devem ter a oportunidade de transferir suas ações pelo mesmo preço e nas mesmas condições aplicáveis ao alienante do controle. Em suma, a oferta pública de que cuida o art. 254 constitui instrumento para assegurar aos minoritários o tratamento igualitário desejado e imposto pelo legislador” (GUERREIRO, José Alexandre Tavares. Alienação de controle de companhia aberta: o papel das instituições financeiras. RDM. São Paulo: Malheiros, n. 30, pp. 115-119, abr./jun. 1978, p. 116).

${ }^{131}$ ROMANO, Roberta (coord.). Foundations of Corporate Law. 2. re-imp. Nova York: Foundation Press, 2004, p. 221. Nesta obra, Roberta Romano reúne textos de autores diversos, inclusive economistas, que tratam de diferentes aspectos do mercado de controle de companhias. Ver também COMPARATO, Fábio Konder; SALOMÃO FILHO, Calixto. O Poder de Controle na Sociedade Anônima. 4. ed. Rio de Janeiro: Forense, 2005, p. 239.

${ }^{132}$ CORDEIRO, António Manuel da Rocha e Menezes. Manual de Direito das Sociedades: das sociedades em especial. v. 2, 2. ed. rev. atual. Coimbra: Almedina, 2007, p. 654. 
todos os que possuem ações votantes da sociedade possam usufruir da operação, aceitando a proposta que lhes é feita para a venda das ações de que são titulares ${ }^{133}$.

Pela oferta pública, o ofertante propõe publicamente para a generalidade dos acionistas detentores de ações votantes da companhia-alvo a aquisição de determinada quantidade de ações, mediante pagamento em dinheiro e/ou permuta por outros bens suscetíveis de avaliação em dinheiro, notadamente ações e/ou outros valores mobiliários $^{134}$.

Usualmente, por questões financeiras e visando a que os acionistas da companhia-alvo venham a aderir à oferta e, consequentemente, vender as suas ações para o ofertante, o preço ${ }^{135}$ estabelecido na oferta é superior ao valor de cotação das ações em bolsa $^{136}$. E, em decorrência dessa elevação do preço ofertado, reconhece-se que tais ofertas públicas podem gerar ganhos significativos para os acionistas da companhia-alvo ${ }^{137}$.

\subsection{HISTÓRICO}

Os relatos históricos sobre as ofertas públicas para aquisição de controle indicam que a origem do instituto se deu na Inglaterra, onde as takeover bids são reguladas

\footnotetext{
${ }^{133}$ MARTINS, Fran. Comentários à Lei das S.A.. v. 3, 2. ed. rev. e aumentada. Rio de Janeiro: Forense, 1985, p. 380.

${ }^{134}$ Esta possibilidade é amplamente lembrada pela doutrina norte-americana e verificada na jurisprudência dos EUA. Por todos, ver CLARK, Robert Charles. Corporate Law. Boston / Toronto: Little, Brown and Company, 1986, p. 531.

$135 \mathrm{O}$ preço da oferta será objeto de estudo no item 4.9.

${ }^{136}$ A título de exemplificação, na doutrina francesa: MERLE, Philippe. Droit commercial: sociétés commerciales. 10. ed. Paris: Dalloz, 2005, p. 790; na doutrina inglesa: MORSE, Geoffrey. Charlesworth's Company Law. 17. ed. Londres: Sweet \& Maxwell, 2005, p. 673; na doutrina norte-americana: BAUMAN, Jeffrey D.; WEISS, Elliot J.; PALMITER, Alan R. Corporations - Law and Policy - Materials and Problems. 5. ed. Saint Paul: Thomson - West Group, 2003, p. 1099; na doutrina portuguesa: CORDEIRO, António Manuel da Rocha e Menezes. Da Tomada de Sociedades (Takeover): Efectivação, Valoração e Técnicas de Defesa. ROA. Lisboa, n. 54, pp. 761-777, 1994, p. 768 (fazendo referência também à doutrina alemã).

${ }^{137}$ ROMANO, Roberta (coord.). Foundations of Corporate Law. 2. re-imp. Nova York: Foundation Press, 2004, p. 222.
} 
desde o Companies Act de $1929^{138}$, tornando-se mais frequentes a partir do início da década de $1950^{139}$.

Entretanto, foram nos EUA que as tender offers desenvolveram-se de maneira mais acentuada e passaram a ocupar destaque na doutrina e na jurisprudência, especialmente na década de 1980, que acabou se tornando conhecida como "deal decade ${ }^{140}{ }^{141}$.

A Suprema Corte de Delaware ${ }^{142}$ examinou reiterados casos de tender offers realizadas por ofertantes interessados em adquirir o controle de companhias-alvo e suas decisões tornaram-se importante fonte do direito nesta matéria.

No Brasil, a doutrina ${ }^{143}$ aponta que a primeira oferta pública hostil para a aquisição de controle de companhia aberta brasileira foi realizada pela Macrosul S.A., com o objetivo de tomar o controle do Sulbanco. O anúncio da oferta pública hostil ocorreu em

${ }^{138}$ COMPARATO, Fabio Konder. Aspectos Jurídicos da Macroempresa. São Paulo: RT, 1970, p. 33.

${ }^{139}$ FERREL, Allen. Why Continental European Takeover Law Matters. Harvard John M. Olin Center for Law, Economics and Business Discussion Paper, n. 454, 2003, p. 10 . Disponível em

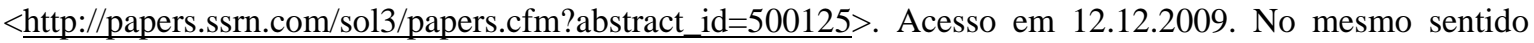
são os relatos históricos de MARTINS, Alexandre Soveral. Valores Mobiliários (Acções). Coimbra: Almedina, 2003, pp. 49-50.

${ }^{140}$ LEITÃO, Luís Manuel Teles de Menezes. As medidas defensivas contra uma oferta pública de aquisição hostil. O Direito. Ano 138, t. III, Coimbra: Almedina, 2006, p. 459.

${ }^{141}$ Há estudos e pesquisas apontando que, durante a "deal decade” (anos 1980), aproximadamente metade das maiores companhias americanas receberam alguma proposta indesejada destinada à tomada de controle, via takeover hostil (conforme MITCHELL, Mark L.; MULHERIN, J. Harold. The Impact of Industry Shocks on Takeover and Restructuring Activity. Journal of Financial Economics. v. 41, 1996, p. 193-229. Disponível em <http://www.sciencedirect.com/science/article/B6VBX ... 49dab9422b24ed4b9a75>. Acesso em 12.12.2009; e GORDON, Jeffrey N. An American Perspective on Anti-Takeover Laws in the EU: The German Example. In: FERRARINI, Guido et al. (org.). Reforming Company and Takeover Law in Europe.

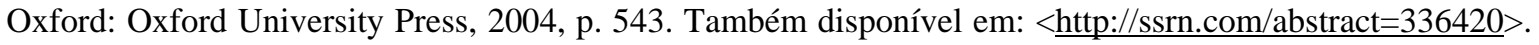
Acesso em 12.12.2009).

${ }^{142}$ Alguns casos submetidos à Suprema Corte de Delaware se tornaram paradigmáticos no estudo da matéria, como, por exemplo, Moran v. Household International, Inc. (500 A.2.d 1346, Delaware, 1985, Rel. John J. McNeilly); Unocal Unocal v. Mesa Petroleum Co. (493 A.2d 946, Delaware, 1985, Rel. Andrew G. T. Moore); Revlon v. MacAndrews and Forbes Holdings, Inc. (506. A.2d 173, Delaware, 1986, Rel. Andrew G. T. Moore); Paramount Communications, Inc. \& KDS Acquisitions Corp. v. Time, Inc. et al. (571 A.2d 1140, Delaware, 1989, Rel. Henry R. Horsey); Paramount Communications, Inc. v. QVC Network, Inc. (637 A.2d 34, Delaware, 1994, Rel. E. Normal Veasey); e Smith v. Van Gorkom (488 A.2d 858, Delaware, 1985, Rel. Henry R. Horsey). Muitos outros casos também são de especial interesse para o estudo das ofertas públicas hostis de aquisição de controle e das proteções contra estas últimas, sendo alguns deles anteriores à década de 1980 e apontados como precursores do entendimento da Suprema Corte de Delaware, como, por exemplo, Cheff v. Mathes e Schnell v. Chris-Craft Industries, Inc. (conforme ALLEN, William T.; KRAAKMAN, Reinier. Commentaries and Cases on the Law of Business Organization. Nova York: Aspen Publishers, 2003, pp. 499-500).

143 CARVALHOSA, Modesto. Comentários à Lei de Sociedades Anônimas. v. 4, t. II, 2. ed. rev. e atual. São Paulo: Saraiva, 2003, p. 201. 
Outubro de 1971, em Porto Alegre - RS, mas a oferta pública fracassou e a Macrosul S.A. retirou a proposta realizada aos acionistas do Sulbanco.

Entretanto, Modesto Carvalhosa ${ }^{144}$ sustenta que a referida experiência frustrada no caso Macrosul v. Sulbanco foi a motivação da discussão das ofertas públicas de aquisição de controle no Brasil e subsequente regulação da matéria por meio da Lei $\mathrm{n}^{\mathrm{o}}$ 6.404/76.

A doutrina pátria refere-se também a outro caso paradigmático de tentativa de tomada de controle realizado no Brasil, em Outubro de 1978, na oferta pública lançada pela Companhia Força e Luz Cataguazes Leopoldina para a aquisição do controle da Companhia Mineira de Eletricidade, na qual a Companhia Energética de Minas Gerais CEMIG apresentou oferta concorrente ${ }^{145}{ }^{146}$.

Em contexto global, inúmeros relatos na doutrina norte-americana ${ }^{147}$ ensinam que, a partir da década de 1950, após o término da $2^{\text {a }}$ Guerra Mundial e o fortalecimento da economia nos EUA e na Inglaterra, investidores financeiros concluíram que certos riscos inerentes a determinados produtos e/ou setores de atuação na economia poderiam ser reduzidos ou, até mesmo, eliminados com a diversificação dos setores em que os investimentos são realizados.

Dessa maneira, despertou-se o interesse pela realização de investimentos simultâneos em outras áreas e setores da economia, originando o movimento de formação de conglomerados, que se alcançava por meio de operações amigáveis (consensuais) ou hostis (não consensuais). Este contexto evidencia o fortalecimento e crescimento do mercado de capitais nos EUA e na Inglaterra.

\footnotetext{
${ }^{144}$ CARVALHOSA, Modesto. Comentários à Lei de Sociedades Anônimas. v. 4, t. II, 2. ed. rev. e atual. São Paulo: Saraiva, 2003, p. 201.

${ }^{145}$ Vide notas de rodapé n. 83-84.

${ }^{146}$ Além de tais casos, há notícias sobre tomada de controle da CEMIG pela Companhia de Eletricidade de Juiz de Fora e da tomada de controle da Cimento Aratu pela Votorantim, em operações realizadas antes da década de 1980 (conforme CORREA, Cristiane; LETHBRIDGE, Tiago. Por que o negócio do ano não saiu? Revista Exame. 28.07.2006).

${ }^{147}$ MOORE, Andrew G.T. The Birth of Unocal: A Brief History. Delaware Journal of Coporate Law. v. 31, n. 3, 2006, pp. 865-886. Disponível em: <http://ssrn.com/abstract=946018>. Acesso em 12.12.2009.
} 
Nos EUA, até a década de 1960, o método usual de aquisições amigáveis, e até mesmo de algumas operações não amigáveis, era a aquisição de ações por permuta. Tal operação se sujeitava a registro perante a SEC, por exigência do Securities Act de 1933. Com relação às aquisições de controle hostis, o método tradicionalmente adotado eram as batalhas por procurações para representação em Assembleias Gerais (proxy fights), as quais eram criticadas por demandarem muito tempo para serem implementadas, pela imprevisibilidade a elas associadas e pela alta regulação a que se submetiam, em decorrência das regras de solicitação de procuração previstas no Securities and Exchange Act de $1934^{148}$.

Ao final da década de 1950 e início da década de 1960 surgiram novos instrumentos para a tomada de controle. Iniciava-se a utilização da assim chamada "Saturday Night Special"149, que sucedeu com eficiência o método anterior das batalhas e disputas por procuração (proxy contests). Pela "Saturday Night Special", o ofertante interessado em adquirir o controle de determinada companhia-alvo realizava oferta pública de aquisição de determinado percentual de seu capital, mediante pagamento em dinheiro $^{150}$.

Os planos para a tomada de controle de companhias passaram a ser estabelecidos em total segredo, por meio de estruturas pré-concebidas. As ofertas públicas hostis para aquisição de controle eram usualmente realizadas em sextas-feiras, ao final do expediente, por preços modestamente superiores aos valores de cotação das ações da companhia-alvo na bolsa de valores. O objetivo era surpreender os acionistas da companhia-alvo, compelindo-os a aceitar a oferta no início da semana subsequente. Estabelecia-se que os pagamentos seriam realizados em dinheiro, à vista, na ordem em que os acionistas da companhia-alvo aceitassem à oferta (first-come, first-served basis), sendo

\footnotetext{
${ }^{148}$ CLARK, Robert Charles. Corporate Law. Boston / Toronto: Little, Brown and Company, 1986, p. 546.

149 A terminologia Saturday Night Special era utilizada em referência, irônica e negativa, aos crimes praticados, nos EUA, durante os finais de semana, utilizando pistolas que eram usualmente adquiridas em mercados e encontravam-se facilmente disponíveis para qualquer interessado em adquiri-las, mediante pagamento em dinheiro, sem a necessidade de cadastramentos e/ou exigências burocráticas. Há relatos de que o termo foi utilizado pela primeira vez na tentativa de tomada de controle da Garlock pela Colt (cf. Garlock Inc. v. Colt Industries Inc. [Complaint, 75 Civ. 5831, SDNY, Nov. 1975]. Apud LIPTON, Martin; STEIBERGER, Erica H. Takeovres \& Freezeouts. v. 1A, Nova York: Law Journal Press, 2003, pp. 6-306-6307).

${ }^{150}$ MOORE, Andrew G.T. The Birth of Unocal: A Brief History. Delaware Journal of Coporate Law. v. 31,

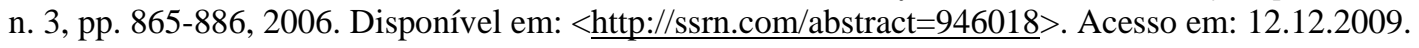


que a oferta estaria limitada a determinado percentual do capital social da companhia-alvo, suficiente, apenas, para que o controle fosse adquirido pelo ofertante.

Dessa maneira, a oferta pública permanecia aberta apenas ao longo do final de semana, com previsão de adesão nos primeiros dias úteis da semana subsequente. Os acionistas que postergassem a adesão ou não aderissem à oferta pública de ações não teriam as suas ações adquiridas pelo ofertante. Em alguns casos, tais acionistas que não aderissem à oferta pública ficavam “congelados” na companhia-alvo e sem qualquer liquidez para vender suas ações no mercado.

Em seguida, após o ofertante assumir o controle da companhia-alvo, os demais acionistas seriam “espremidos” para fora da companhia-alvo (squeeze out), usualmente por: (i) uma segunda oferta pública de aquisição de ações, desta vez com valores mais baixos do que na primeira oferta pública; ou (ii) incorporação da companhia-alvo em outra companhia existente detida pelo acionista controlador que havia recém-adquirido o controle da companhia-alvo. Consequentemente, as ações da companhia-alvo que não haviam sido adquiridas na oferta pública eram substituídas por ações da companhia incorporadora, sendo que esta última era geralmente uma companhia com valores mobiliários subordinados (junk bonds).

Dessa forma, realizava-se a clássica "two-tier takeover" ${ }^{151}$, operação de tomada de controle que conjugava uma oferta pública de aquisição de ações representativas do controle da companhia-alvo seguida de: (i) oferta pública de aquisição de ações por valor significativamente menor do que aquele oferecido na oferta pública em que se adquiriu o controle; ou (ii) operação de incorporação da companhia-alvo em outra companhia.

\footnotetext{
${ }^{151}$ No Brasil, o modelo do two-tier takeover, comumente adotado nos EUA durante as décadas de 1960 a 1980, não pode ser aplicado de forma idêntica nas nossas companhias abertas. A legislação brasileira prevê mecanismos de proteção às minorias acionárias capazes de inviabilizar a adoção de tal modelo. Neste sentido, o artigo 254-A da Lei no 6.404/76 prevê o tag along dos acionistas minoritários, que assegura que "a alienação, direta ou indireta, do controle de companhia aberta somente poderá ser contratada sob a condição, suspensiva ou resolutiva, de que o adquirente se obrigue a fazer oferta pública de aquisição das ações com direito a voto de propriedade dos demais acionistas da companhia, de modo a lhes assegurar o preço no mínimo igual a $80 \%$ (oitenta por cento) do valor pago por ação com direito a voto, integrante do bloco de controle." Deste modo, há uma natural redução da potencial pressão coercitiva associada à two-tier takeover. Esclareça-se que, no caso de companhias abertas listadas no segmento do Novo Mercado BM\&F-Bovespa, o tag along assegurado aos minoritários é igual ao preço adotado na operação de alienação de controle de tal companhia.
} 
A tática de tomada de controle adotada contemplava a realização de uma oferta pública, por valor ligeiramente acima do valor de mercado, prevendo a aquisição de ações suficientes à assunção de participação superior a 50\% do capital votante, com previsão de pagamento em dinheiro (front-end). Em seguida, tão logo se encerrasse o prazo para adesão à oferta pública e o ofertante adquirisse o controle da companhia-alvo, os acionistas remanescentes seriam eliminados pela incorporação da companhia-alvo em outra companhia detida pelo ofertante (squeeze out merger) ou por meio de outro mecanismo de compra de suas ações por valor inferior àquele oferecido na oferta pública de aquisição de controle (back-end).

O sucesso da Saturday Night Special estava associado à pressão coercitiva ${ }^{152}$ que recaia sobre os acionistas da companhia-alvo para aderir à oferta pública realizada pelo ofertante, sob pena de, em vez de assegurar o recebimento por suas ações do valor ligeiramente superior ao de negociação em bolsa de valores, serem submetidos à incorporação após a tomada de controle, na qual as ações eram substituídas por junk bonds, ou se tornarem acionistas detentores de ações sem liquidez no mercado, que potencialmente despertariam interesse de serem adquiridas apenas pelo acionista que havia recém-adquirido o controle da companhia-alvo.

Os membros da administração da companhia-alvo eram surpreendidos pela oferta pública de aquisição de ações e, na maioria dos casos, não estavam preparados para adotar nenhuma medida que efetivamente pudesse auxiliar seus acionistas a resistirem à oferta pública. Assim sendo, fortaleceram-se e tornaram-se frequentes os takeovers hostis, com suporte em argumentos de conteúdo econômico. ${ }^{153}$

\footnotetext{
152 Tal pressão coercitiva seria inaplicável em sistemas jurídicos que assegurassem prazo razoável para os acionistas se posicionarem quanto à oferta pública e regras básicas de tratamento igualitário entre aceitantes da oferta, de modo a evitar a "corrida à aceitação”, que era causada pelo procedimento do first-come, firstserved basis.

153 Os argumentos básicos em defesa dos takeovers hostis têm conteúdo substancialmente econômico, exemplificativamente, entendendo que: (i) a simples possibilidade de um takeover estimula a administração à consistentemente maximizar (no curto prazo) o valor das participações acionárias da companhia, de modo a evitarem tentativas de tomada de controle realizadas através de ofertas públicas ao mercado; e (ii) quando há a tomada do controle de companhia, com desempenho abaixo da expectativa, há a tendência de que as ineficiências sejam eliminadas, tornando a companhia mais eficiente e, consequentemente, elevando o valor das participações acionárias (MOORE, Andrew G.T. The Birth of Unocal: A Brief History. Delaware Journal of Coporate Law. v. 31, n. 3, 2006, pp. 865-886. Disponível em: < http://ssrn.com/abstract=946018>. Acesso em 12.12.2009).
} 
Com o objetivo de solucionar a questão, adotou-se nos EUA o Williams Act de $1968^{154}$, que alterou o Securities Exchange Act de 1934, a fim de acabar com as Saturday Night Specials.

Originalmente, o Williams Act aplicava-se apenas às ofertas públicas para aquisição de controle realizadas para pagamento em dinheiro, as quais até então não eram reguladas. Posteriormente, tal diploma foi expandido para incluir todas as ofertas públicas de aquisição de controle. Em sua proposta original, o diploma previa a adoção de inúmeras regras restritivas às ofertas públicas de aquisição de ações. Entretanto, após revisões às quais a proposta inicial foi submetida, o Williams Act acabou tornando-se uma legislação preponderantemente destinada à divulgação de informação, e não um ordenamento restritivo às tomadas de controle ${ }^{155}$.

O Williams Act alcançou êxito em seus objetivos, encerrando a epidemia das tomadas de controle, sob a forma de Saturday Night Specials, mas não representou a solução de todos os males relativos às ofertas públicas hostis para tomada de controle. $\mathrm{O}$ impacto inicial do Williams Act foi reduzir expressivamente o número de tentativas de tomada de controle ${ }^{156}$, mas estas não deixaram de ser utilizadas de forma contínua e

${ }^{154} \mathrm{O}$ Williams Act é uma lei federal dos EUA, que foi originalmente proposta pelo Senador Harrison Williams, tendo sido aprovada em 1968 e posteriormente aditada em 1970. Tal lei alterou regras do Securities Exchange Act de 1934. O principal objetivo do Williams Act era reduzir a pressão imposta aos acionistas da companhia-alvo de aderirem à oferta pública realizada pelo potencial tomador do controle de tal companhia-alvo, assegurando que uma oferta pública esteja aberta à adesão dos acionistas por período longo o suficiente para que os acionistas destinatários da oferta pública pudessem refletir sobre a mesma. Uma das principais ideias do Williams Act era acabar com a “two-tier takeover”. O Williams Act estabeleceu rigorosas exigências de divulgação de informações por parte do ofertante no âmbito da oferta pública, com potencial sanção de estender o prazo de adesão à oferta pública caso a divulgação de informação não fosse realizada devidamente. O diploma também tinha como efeito tornar mais longo o período de realização e conclusão das ofertas públicas, propiciando meios para que os administradores e/ou acionistas relevantes da companhiaalvo pudessem adotar medidas defensivas contra a iminente tomada de controle. Para maiores informações, referir-se a CHOPER, Jesse H.; COFFEE Jr., John C.; e GILSON, Ronald J. Cases and materials on corporations. 7. ed. Nova York: Aspen Publishers, 2008 (notadamente o Capítulo IX “E” - Federal Regulation of Takeover, pp. 1076-1088).

${ }^{155}$ Os doutrinadores norte-americanos Jesse Choper, John Coffee Jr. e Ronald J. Gilson dão notícia de que: "As first proposed, the Williams Act would have largely curtailed tender offer through substantive restrictions. Congress had become alarmed that large corporations were being rapidly taken over by unknown "raiders" and wished to slow down this movement. However, the SEC succeeded in redrafting the proposed bill, turning it largely into a disclosure statute. In a much-quoted statement, Senator Williams observed that the Act, as finally passed, was designed not to tip the balance in favor of either side” (Ibid., pp. 943-944).

${ }^{156}$ Os ofertantes temiam que eventual omissão relevante de informações exigidas pelo Williams Act pudessem tornar suas ofertas públicas permanentemente aceitáveis para a pluralidade de acionistas da companhia-alvo, tornando a tomada de controle economicamente desinteressante e fora de controle por parte do ofertante. A experiência prática americana revelou, em alguns casos, que este temor não seria em vão, tal 
frequente, contudo passaram a ser realizadas com limitações temporais e exigências para que os acionistas da companhia-alvo não se sentissem tão compelidos a aderir a toda e qualquer oferta pública que fosse realizada.

As ofertas públicas hostis para tomada de controle continuaram existindo e se desenvolvendo, mas os órgãos da administração da companhia-alvo passaram a dispor de mais tempo para orientar os acionistas em relação à oferta e, em alguns casos, adotar medidas defensivas e resistir aos takeovers hostis.

Após o Williams Act e com a crescente utilização de ofertas públicas como mecanismo para a tomada de controle de companhias abertas nos EUA, a década de 1980 presenciou o ápice do fenômeno dos takeovers e da oposição de defesas a estes. Por esta razão, a década de 1980 tornou-se famosa como a deal decade, em que inúmeras companhias abertas norte-americanas receberam uma oferta hostil, que normalmente consistia em tentativa de obtenção de lucros rápidos (bust up), por meio da venda imediata de ativos e/ou segmentos de atuação da companhia-alvo.

Ao longo da década de 1980, inúmeros estados norte-americanos passaram a adotar legislações estaduais regulando as tentativas de tomada de controle e, em alguns casos, proibindo-as ${ }^{157}$.

como no caso General Host Corp. v. Triumph American Inc. (359 F. Supp. 749, Corte Federal de Distrito de Nova York - SDNY, 1973), em que o ofertante não revelou total e devidamente seus planos em relação à companhia-alvo e suas tentativas anteriores de liquidar parcialmente companhias recém-adquiridas, razão pela qual o prazo previsto aos acionistas da companhia-alvo para adesão à oferta pública foi substancialmente ampliado.

${ }^{157}$ Jesse Choper, John Coffee Jr. e Ronald J. Gilson explicam que as legislações estaduais destinadas a regular as tentativas de tomada de controle enquadravam-se em duas gerações. Em meados de 1970, os estados norte-americanos começaram a adotar ordenamentos contra as tomadas de controle (anti-takeover statutes), na chamada primeira geração de tais legislações estaduais. A maioria de tais legislações estaduais inspirava-se no modelo do Estado de Illinois (Illinois Business Takeover Act). Entretanto, este diploma legal veio a ser declarado inconstitucional pela Suprema Corte dos EUA, no início da década de 1980, sob o entendimento de que violava o princípio constitucional americano da liberdade do comércio. Em seguida, surgiram os ordenamentos contra tomadas de controle (anti-takeover statutes) de segunda geração, com destaque ao modelo do Estado de Indiana (Indiana Control Share Acquisition Statute), estruturalmente replicado por outros estados norte-americanos, como Nova Iorque e Nova Jersey. Em 1987, examinando o paradigmático caso CTS Corp. v. Dynamics Corp. of America (481 US 69, Suprema Corte dos Estados Unidos, 1987, Rel. Lewis Powell), a Suprema Corte dos EUA reconheceu a validade do ordenamento antitakeover adotado pelo Estado de Indiana. Após tal decisão da Suprema Corte dos EUA, inúmeros estados norte-americanos estabeleceram alguma forma de ordenamento anti-takeover, sendo que o estado da Pensilvânia proibiu a realização de ofertas hostis (CHOPER, Jesse H.; COFFEE Jr., John C.; e GILSON, Ronald J. Cases and materials on corporations. 7. ed. Nova York: Aspen Publishers, 2008, p. 944). Para uma 
As ofertas públicas hostis, que se tornaram fenômeno muito comum nos EUA, especialmente na década de 1980, tornaram-se mais escassas a partir da década de 1990. O período de wild west capitalism ${ }^{158}$ interrompeu-se, dentre outros motivos, com a mudança dos regimes jurídicos de estados norte-americanos, muitos dos quais alteraram leis e regras aplicáveis às medidas defensivas potencialmente adotáveis por companhias-alvo ${ }^{159}$.

A doutrina estrangeira ${ }^{160}$ explica algumas razões que contribuíram para tal redução do grau de hostilidade das ofertas, dentre as quais se destacam a evolução de métodos eficientes de proteção contra as tomadas de controle hostis, a adaptação dos institutos de direito societário nos EUA, com a tendência de os administradores americanos sentirem-se menos estimulados a resistir contra tomadas de controle realizadas por meio de propostas com pagamento de prêmios aos acionistas ${ }^{161}$ e o reconhecimento, pelos tribunais americanos, de que tais medidas defensivas poderiam ser adotadas sem violação à lei.

A redução do número de ofertas hostis nos EUA, a partir da década de 1990, também é efeito de algumas evidências financeiras. Estudos empíricos demonstram que os resultados obtidos pelo ofertante com a aquisição do controle e posterior alienação da companhia-alvo e/ou de certos bens e ativos desta última reduziram com o aumento da regulação sobre as ofertas públicas de aquisição de controle. Portanto, tornou-se menos recompensador, do ponto de vista financeiro, a realização das ofertas públicas de aquisição

abordagem de direito societário comparado no que tange às legislações estaduais norte-americanas contra tomadas de controle (anti-takeover statutes), referir-se ao genial autor português António Menezes Cordeiro (CORDEIRO, António Manuel da Rocha e Menezes. Ofertas Públicas de Aquisição. ROA. Lisboa, n. 56, pp. 499-533, 1996, p. 501).

${ }^{158}$ Coloquialmente atribuído à década de 1980, em decorrência dos frequentes movimentos de tomada de controle.

${ }^{159}$ Jeffrey N. Gordon ensina que "licensed by a 1987 US Supreme Court case - CTS Corp vs. Dynamics Corp of America 481 US 69 (1987) - states adopted anti-takeover statutes that would survive judicial scrutiny. In measuring the fiduciary duty of target directors, state courts adopted increasingly deferential attitudes toward defensive measures [...]" (GORDON, Jeffrey N. An American Perspective on AntiTakeover Laws in the EU: The German Example. In: FERRARINI, Guido et al. (org.). Reforming Company and Takeover Law in Europe. Oxford: Oxford University Press, 2004, p. 543. Disponível em: $<$ http://ssrn.com/abstract=336420 $>$. Acesso em 12.12.2009).

${ }^{160}$ Conforme Jeffrey N. Gordon (Ibid., pp. 541-559) e Menezes Leitão (LEITÃO, Luís Manuel Teles de Menezes. As medidas defensivas contra uma oferta pública de aquisição hostil. O Direito. Ano 138, t. III, Coimbra: Almedina, 2006, p. 459).

${ }^{161}$ Segundo ensina Jeffrey N. Gordon, "acquisition activity in the US in the 1990s was, if anything, more intense than in the 1980s, measured both as a percent of market capitalization and in the number of transactions, and much greater if measured in real dollar terms or as a percent of GDP. The degree of reported 'hostility' declined across the decade [...]”' (GORDON, Jeffrey N. Op. cit., p. 544. 
de controle, que, consequentemente, tornaram-se menos frequentes ${ }^{162}$. A tendência era a realização de operações amigáveis ou operações inicialmente hostis que se convertiam em operações amigáveis.

\subsection{NATUREZA JURÍDICA}

Quanto à sua natureza jurídica, entende-se que a oferta pública para aquisição de controle constitui negócio jurídico unilateral, ou declaração negocial (unilateral) receptícia de vontade, por ser dirigida a sujeitos indeterminados, mas determináveis - os acionistas da companhia-alvo ${ }^{163}$-, sendo equivalente à proposta de contrato ${ }^{164}$, nos termos do artigo 429 do Código Civil ${ }^{165}$.

Examinando a natureza jurídica da oferta pública prevista no artigo 257 da Lei $\mathrm{n}^{\circ}$ 6.404/76, Modesto Carvalhosa doutrina que:

[c]onfigura-se a oferta por uma declaração unilateral de vontade, tendo efeitos vinculantes por si mesma, e criando obrigações para o ofertante, mesmo que o contrato de aquisição de ações, cuja realização se almeja, não venha a existir. [...] Constitui a oferta, portanto, um ato jurídico autônomo, não se confundindo com o contrato cuja formação contribui. É

\footnotetext{
${ }^{162}$ Gregg A. Jarrel, James A. Brickley e Jeffrey M. Netter explicam que "the apparent secular decline in the gains to successful bidders in tender offers [...] positive excess returns of 5 percent during the 1960s, and a lower, but still significantly significant, positive average of 2.2 percent over the 1970 s. However, the [...] cases from the 1980s show statistically insignificant losses to bidders" (JARREL, Gregg A.; BRICKLEY, James A.; NETTER, Jeffry M. The Market for Corporate Control: The Empirical Evidence Since 1980. In: ROMANO, Roberta [coord.]. Foundations of Corporate Law. 2. re-imp. Nova York: Foundation Press, 2004, p. 243).

${ }^{163}$ FRANCO, Vera Helena de Mello. Considerações sobre as Ofertas Públicas para Aquisição de Ações (OPAs): estado atual da questão. RDM. São Paulo: Malheiros, n. 144, pp. 16-58, out./dez. 2006, p. 30 e ss.

${ }^{164}$ A oferta pública de aquisição de ações reveste a natureza jurídica de uma proposta contratual, sendo atualmente pacífica tal qualificação, distinguindo-a de figuras semelhantes como o "convite para contratar, a promessa pública ou o contrato-promessa unilateral”. A este respeito, referir-se a PEREIRA, Jorge Brito. A OPA Obrigatória. Coimbra: Almedina,1998, pp. 21-24.

${ }^{165}$ COMPARATO, Fábio Konder; SALOMÃO FILHO, Calixto. O Poder de Controle na Sociedade Anônima. 4. ed. Rio de Janeiro: Forense, 2005, pp. 257-258.
} 
um ato negocial, pois representa uma vontade definitivamente separada de seu autor e que se torna objetiva ${ }^{166}$.

Embora a oferta pública de aquisição de ações não crie um vínculo contratual propriamente dito, uma vez que a relação contratual pressupõe o encontro de vontades do ofertante (ao realizar a oferta) e do ofertado (ao aceitá-la), uma vez realizada a oferta pública o ofertante deverá respeitá-la e estará a ela vinculado.

Se a natureza jurídica da oferta pública de aquisição de controle assemelha-se a de uma proposta de contrato, é importante ponderar sobre os efeitos decorrentes de propostas formuladas pelo ofertante aos acionistas da companhia-alvo.

Oferta e aceitação são os atos essenciais de formação do contrato e, por esta razão, devem ser coincidentes. Como declarações de vontade, dirigidas à formação futura de um negócio jurídico bilateral (o contrato), produzem efeitos jurídicos. No caso da oferta, a primeira fase efetiva do contrato, a vontade declarada pelo proponente é, para ele, vinculativa.

Além disso, a oferta de contrato deve ser formulada, pelo ofertante, com a intenção firme de vincular-se, em caráter definitivo, devendo ainda ser completa, ou seja, deve conter os elementos essenciais do contrato que visa a confeccionar, de maneira que só reste ao interessado, a quem se dirigiu a oferta, aceitá-la ou não. Segundo Darcy Bessone, a "vontade de contrair obrigação deve ser séria, obrigante e definitiva". ${ }^{167}$

Sabe-se que a oferta pública de aquisição de controle, como o próprio nome indica, é realizada para a aquisição do controle da companhia-alvo, sendo de sua essência que venha a materializar-se em contrato apenas se um determinado número mínimo de acionistas aderir à oferta. Significa dizer que a proposta de contrato é realizada sob a

\footnotetext{
${ }^{166}$ CARVALHOSA, Modesto. Comentários à Lei de Sociedades Anônimas. v. 4, t. II, 2. ed. rev. e atual. São Paulo: Saraiva, 2003, pp. 209-210.

${ }^{167}$ BESSONE, Darcy. Do contrato: teoria geral. São Paulo: Saraiva, 1997, p. 122.
} 
condição suspensiva de que haja uma adesão mínima, nos termos do artigo 125 do Código Civil $^{168}$. Caso contrário, o negócio jurídico proposto pelo ofertante não se tornará eficaz.

Sendo assim, pode-se entender que a natureza jurídica da oferta pública de aquisição de controle assemelha-se a de uma proposta de contrato, sob condição suspensiva.

Da natureza jurídica do instituto decorre a essência da oferta pública, no sentido de que a proposta/oferta obriga ${ }^{169}$ o proponente, se o contrário não resultar dos termos dela, da natureza do negócio, ou das circunstâncias do caso, tal como determina o artigo 427 do Código Civil.

Portanto, caso a condição suspensiva da oferta pública de aquisição de controle (i.e., adesão mínima de acionistas, tal como exposto no anúncio de oferta) seja satisfeita, o ofertante deverá tornar efetivo o negócio jurídico de aquisição das ações. Em caso de descumprimento por parte do ofertante, o adimplemento será assegurado pela instituição

\footnotetext{
${ }^{168} \mathrm{O}$ artigo 125 do Código Civil prescreve que "subordinando-se a eficácia do negócio jurídico à condição suspensiva, enquanto esta não se verificar, não terá adquirido o direito a que ele visa”.

${ }^{169}$ Conforme a dicção do art. 427 do Código Civil (que reproduz a regra do art. 1.080 do Código Civil de 1916), “a proposta de contrato obriga o proponente”. Alcides Tomasetti Jr. leciona, a respeito desta regra, que o Código Civil “atribui obrigação ao agente do negócio jurídico unilateral. 'Obrigação’ (latissimo sensu) de sustentar a proposta contratual, e de sujeitar-se o proponente às conseqüências da aceitação da oferta” (TOMASETTI JR., Alcides. Oferta contratual em mensagem publicitária: regime do direito comum e do Código de Proteção do Consumidor. RDC. São Paulo: RT, n. 4, pp. 241-254, out./dez. 1992, p. 245, grifo do autor). Na proposta feita com os requisitos legais, há propriamente uma obrigação. Por vezes, emprega-se o termo "obrigação" e "vinculação" indistintamente, mas cremos ser mais apropriado falar em obrigação, e não em vinculação, termos muito próximos, mas não necessariamente coincidentes. E isto porque se trata, a obrigação, de uma "relação jurídica, em virtude da qual um sujeito ativo (credor) pode exigir do sujeito passivo (devedor) uma prestação ou uma abstenção” (SOUZA, Ernani Vieira de. Obrigação. In: Enciclopédia Saraiva do Direito, v. 55, São Paulo: Saraiva, 1977, p. 271), ao passo que a vinculação (de vínculo) assume uma conotação mais genérica, de ligar uma pessoa a outra por meio de uma obrigação, exprimindo, assim, mais a relação jurídica do que propriamente a obrigação (cf., a propósito, DE PLÁCIDO E SILVA. Vocabulário Jurídico. 23. ed. Rio de Janeiro: Forense, 2003, pp. 1486-1487). Vê-se que a diferença é sutil. Sob esta perspectiva, pode-se dizer que, com a declaração negocial, nasce a obrigação, e, com a aceitação, o vínculo obrigacional, consubstanciado no contrato. Entende-se, nessa linha, o vínculo como elemento essencial da obrigação, mas não seu sinônimo (embora a própria obrigação possa ser definida como um vínculo de direito). Há que se traçar também uma distinção, lembrada pelos estudiosos do Direito Civil, de que obrigatoriedade não é sinônimo de irrevogabilidade. Em se tratando da oferta pública de aquisições, porém, o caráter irrevogável foi imposto pelo próprio legislador, no $\S 2^{\circ}$ do art. 257 da Lei $n^{\circ}$. 6.404/76. O ofertante, ao emitir a proposta, fica obrigado a cumpri-la em seus termos, tornando-se responsável por sua manutenção. No caso de descumprimento, sujeita-se à reparação das perdas e danos causados, mas há quem fale, na doutrina mais atual, na possibilidade de os interessados, a quem se dirigiu a oferta, pleitearem não as perdas e danos, mas a execução específica daquela obrigação. O tema, contudo, não constitui foco de atenção deste trabalho, na medida em que a oferta pública de aquisição de ações, que por determinação legal é irrevogável, deve vir acompanhada de garantia prestada por instituição financeira, que se obriga a pagar o valor oferecido pelas ações, na hipótese de o adquirente faltar com sua obrigação.
} 
financeira garantidora, nos termos do artigo 257 da Lei ${ }^{\circ}$ 6.404/76 e demais dispositivos legais aplicáveis, que estão analisados no item 4.5.

Modesto Carvalhosa explica que a oferta pública, como ato negocial, isto é, anterior à formação do vínculo contratual propriamente dito:

[...] reveste-se de caráter autônomo, prevalecendo nas hipóteses de sucessão a qualquer título [do proponente]. Os seus efeitos prevalecem nos casos de reorganização e consolidação de companhias em que esteja envolvida a sociedade proponente. [...] A pessoa jurídica que suceder a companhia proponente estará vinculada à proposta, não podendo escusarse de mantê-la ${ }^{170}$.

Mauro Rodrigues Penteado conclui e doutrina que a oferta pública é “negócio jurídico privado, cuja formação engloba a prática de atos seriados e interdependentes, todos eles amalgamados pelo substrato comum”171, que no caso da oferta pública do artigo 257 da Lei $n^{\circ}$ 6.404/76 é a aquisição de ações em quantidade que assegure ao ofertante o poder de controle sobre a companhia-alvo.

\section{LEGISLAÇÃo APLICÁVEL}

No Brasil, os artigos 257 a 263 da Lei $n^{\circ}$ 6.404/76 e a Instrução CVM nº $361 / 02^{172}$ regulam as oferta públicas para aquisição de controle.

A Lei $n^{0}$ 6.404/76 inova em matéria legislativa ao regular, pela primeira vez em nosso sistema jurídico, a aquisição de controle mediante oferta pública. A Exposição de

\footnotetext{
${ }^{170}$ CARVALHOSA, Modesto. Comentários à Lei de Sociedades Anônimas. v. 4, t. II, 2. ed. rev. e atual. São Paulo: Saraiva, 2003, p. 220.

${ }^{171}$ PENTEADO, Mauro Rodrigues. Apontamentos sobre a Alienação do Controle de Companhias Abertas. RDM. São Paulo: Malheiros, n. 76, pp. 15-25, out./dez. 1989, p. 22.

${ }^{172}$ Com as alterações introduzidas pela Instrução CVM no 436/06, que acrescentou o Anexo III à Instrução $\mathrm{CVM}^{\circ}$ 361/02, com exigências em relação ao laudo de avaliação exigido em casos de ofertas públicas realizadas pela própria companhia, pelo acionista controlador ou por pessoa a ele vinculada (artigo $8^{\circ}$, $\S 3^{\circ}$, da Instrução CVM no 361/02) e em relação ao laudo de avaliação no caso de oferta de permuta, referente aos valores mobiliários entregues na permuta (artigo 8º , §7º da Instrução CVM nº 361/02).
} 
Motivos do Anteprojeto ${ }^{173}$ que resultou na Lei $n^{\circ}$ 6.404/76 consignou a necessidade de regular a matéria, tendo em vista as consequências negativas que uma oferta sem observância de normas que tenham em conta todos os interesses envolvidos poderia trazer ao mercado.

A inserção de regras sobre a oferta pública de aquisição de controle na legislação pátria foi, à época, recebida com satisfação pela doutrina nacional. Rubens Requião, ao examinar a Exposição de Motivos do Anteprojeto que resultou na Lei $\mathrm{n}^{\circ}$ 6.404/76, ponderou que:

[...] deixa, pois, entrever [...] a intenção do legislador de introduzir na futura legislação, o sistema da oferta pública de compra de ações, ou seja, o sistema norte-americano conhecido por takeover bid. [...] No sistema o pretendente comprador não efetua negócios privados e reservados apenas com o grupo de 'controle', mas faz uma oferta pública de compra de ações, dirigida a todos os acionistas, prontificando-se a adquirir, de quem quiser vendê-las, por preço e condições uniformes dependendo de condição suspensiva, i.e., de se adquirir o 'controle' ${ }^{174}$.

O artigo 257 da Lei n 6.404/76 estabelece que “a oferta pública para aquisição de controle de companhia aberta somente poderá ser feita com a participação de instituição financeira que garanta o cumprimento das obrigações assumidas pelo ofertante”.

O propósito do referido dispositivo legal é garantir aos acionistas da companhia-alvo que a proposta realizada pelo ofertante será cumprida, reforçando tal certeza com o envolvimento de instituição financeira capaz de assegurar a viabilidade econômica da proposta do ofertante.

\footnotetext{
173 “O Projeto regula a aquisição de controle mediante oferta pública - processo de uso frequente no direito norte-americano e inglês, já regulado no direito francês, e que, mesmo entre nós, apresenta alguns precedentes. Impõe-se, por isso, o quanto antes, seja disciplinado em lei, dado as profundas perturbações que uma oferta idônea, ou sem observância de normas que tenham em conta todos os interesses envolvidos, pode trazer ao mercado, em prejuízo das empresas e, especialmente, de acionistas e investidores em valores mobiliários. As normas constantes do projeto, nos artigos 258 a 264, são as que lograram o consenso geral em outras legislações, com as imprescindíveis adaptações ao nosso sistema” (LAMY FILHO, Alfredo; BULHÕES PEDREIRA, José Luiz. A Lei das S.A. v. 2, 2. ed. Rio de Janeiro: Renovar, 1996, p. 256).

${ }^{174}$ REQUIÃO, Rubens. O Controle e a Proteção dos Acionistas. RDM. São Paulo: Malheiros, n. 15/16, pp. 23-36, out./dez. 1974, p. 32.
} 
Há, na doutrina pátria, divergência quanto às características da garantia prestada pela instituição financeira. De um lado, coloca-se a douta opinião de Modesto Carvalhosa ${ }^{175}$ e de Alfredo Sérgio Lazzareschi Neto ${ }^{176}$ no sentido de que a posição jurídica ocupada pela instituição financeira é a de obrigada solidária com o ofertante pelo cumprimento das obrigações assumidas nas ofertas públicas de aquisição de ações. De outro lado, coloca-se a sempre coerente opinião dos autores José Alexandre Tavares Guerreiro e Egberto Lacerda Teixeira ${ }^{177}$, acompanhados do respeitável Fran Martins ${ }^{178}$, que entendem que a instituição financeira presta uma garantia subsidiária pelo pagamento das ações que o ofertante propôs adquirir. Destaque-se, ainda, a opinião de Roberto Barcellos de Magalhães ${ }^{179}$ e de Fernando Netto Boiteux ${ }^{180}$, de que a instituição financeira funcionará como fiadora do ofertante quanto ao fiel cumprimento das obrigações que assumir.

Neste ponto, filiamo-nos à opinião de José Alexandre Tavares Guerreiro, Egberto Lacerda Teixeira e Fran Martins, por entender que solidariedade não se presume, decorre da lei ou da vontade das partes, conforme previsto no artigo 265 do Código Civil. A instituição financeira somente deverá cumprir subsidiariamente a obrigação pecuniária, assumida pelo ofertante, de pagar pelas ações que este se propôs a adquirir.

O legislador, ao obrigar o envolvimento de instituições financeiras garantidoras das propostas realizadas pelos ofertantes, tem o objetivo de evitar o "surgimento de ofertas temerárias ou meramente especulativas, que, além de perturbarem o mercado, afetam,

\footnotetext{
${ }^{175}$ CARVALHOSA, Modesto. Comentários à Lei de Sociedades Anônimas. v. 4, t. II, 2. ed. rev. e atual. São Paulo: Saraiva, 2003, p. 207.

${ }^{176}$ LAZZARESCHI NETO, Alfredo Sérgio. Lei das Sociedades por Ações Anotada. 2. ed. rev. ampl. e atual. São Paulo: Saraiva, 2008, p. 718.

${ }^{177}$ GUERREIRO, José Alexandre Tavares; TEIXEIRA, Egberto Lacerda. Sociedades anônimas no direito brasileiro. São Paulo: Bushatsky, 1979, pp. 761-762.

${ }^{178}$ MARTINS, Fran. Comentários à Lei das Sociedades Anônimas. v. 3, 2. ed. rev. e aumentada. Rio de Janeiro: Forense, 1985, p. 384.

${ }^{179}$ MAGALHÃES, Roberto Barcellos de. Lei das S.A.: comentários por artigo. v. 2, 2. ed. rev. e atual. Rio de Janeiro: Freitas Bastos, 1997, p. 965.

${ }^{180}$ BOITEUX, Fernando Netto. Oferta pública de aquisição de controle de companhia aberta. RF. Rio de Janeiro: Forense, n. 301, pp. 53-72, jan./mar. 1988, p. 62. Fernando Netto Boiteux registra este entendimento com apoio em opinião de Modesto Carvalhosa que, contraditoriamente com a sua própria posição referenciada acima (cf. nota 175), ensinava que "se o proponente não pagar o preço, caberá à instituição cujo nome consta da oferta, substitutivamente, fazê-lo a favor do aceitante. Além da operação de garantia, poderão o ofertante e a instituição garantidora convencionar o próprio financiamento da operação. Este negócio de mútuo não se confunde com o outro, de fiança” (CARVALHOSA, Modesto. Oferta pública de aquisição de ações. Rio de Janeiro: IBMEC, 1979, p. 157).
} 
desnecessariamente, a imagem da companhia-alvo, podendo, ademais, causar danos patrimoniais aos eventuais acionistas aceitantes”181.

A garantia prestada pela instituição financeira consiste em garantia pessoal ${ }^{182}$, destinada a assegurar o cumprimento da obrigação de pagar assumida pelo ofertante em favor dos ofertados, respeitados os termos do edital de oferta. Embora o artigo 257 da Lei $\mathrm{n}^{\circ}$ 6.404/76 adote redação abrangente, determinando de modo generalizado que a oferta só poderá ser realizada com a participação de instituição financeira "que garanta o cumprimento das obrigações assumidas pelo ofertante”, esta última só estará obrigada a assegurar o pagamento, não nos parecendo coerente entender que, em caso de inadimplemento do ofertante, a instituição financeira assumirá integralmente a posição de principal obrigada, ocupada pelo ofertante, de adquirir e assumir o controle da companhiaalvo. O controle será adquirido pelo ofertante, que se tornará devedor da instituição financeira garantidora, pelo montante que esta houver desembolsado no âmbito da garantia.

A oferta pública para aquisição de controle da companhia é, como já se registrou, voluntária e, como tal, prescinde de registro perante a CVM para que seja realizada. Entretanto, em caráter excepcional, o $\S 1^{\circ}$ do artigo 257 da Lei $n^{\circ}$ 6.404/76 exige

${ }^{181}$ CARVALHOSA, Modesto. Comentários à Lei de Sociedades Anônimas. v. 4, t. II, 2. ed. rev. e atual. São Paulo: Saraiva, 2003, p. 200.

${ }^{182}$ Como garantia de natureza pessoal (ou fidejussória), reveste-se de duas características fundamentais, que ajudam a caracterizar o papel desempenhado pela instituição financeira nas ofertas públicas de aquisição de controle acionário: (i) acessoriedade (no sentido de ser garantia acessória da obrigação principal); e (ii) subsidiariedade (no sentido de que o garantidor só responde se restar demonstrada a insuficiência do patrimônio do devedor para satisfazer a obrigação, podendo alegar em seu favor o benefício de ordem, a menos que se convencione diversamente). Outra observação que reforça esse entendimento extrai-se do art. $7^{\circ}$, §4 ${ }^{\circ}$, da Instrução CVM n ${ }^{\circ}$. 361/02, segundo o qual "a instituição intermediária garantirá a liquidação financeira da OPA e o pagamento do preço de compra”. A análise desses elementos conduz à conclusão de que se trata, de fato, de garantia pessoal ou fidejussória, e, poder-se-ia dizer mais, de uma garantia cuja natureza jurídica é de fiança, espécie paradigmática das demais garantias pessoais. Já no início da década de 1970, Fábio Konder Comparato, examinando as take-over bids no âmbito da regulamentação francesa, falava da exigência de "que a oferta seja afiançada por um Banco" (COMPARATO, Fábio Konder. Novas formas jurídicas de concentração empresarial. RDM. São Paulo: Malheiros, n. 5, pp. 133-142, jan./mar. 1972, p. 137). Tal garantia implica a existência de um segundo patrimônio (do fiador) para responder pela satisfação da obrigação, cumulativa e subsidiariamente ao patrimônio do devedor, constituindo, assim, "um contrato que tem por objeto a obrigação assumida por uma pessoa com o credor de outra de pagar a dívida desta, caso ela não o faça” (ESPÍNOLA, Eduardo. Garantia e extinção das obrigações. Atualizado por Francisco José Galvão Bruno. Campinas: Bookseller, 2005, p. 280. No mesmo sentido, a doutrina portuguesa: MARTINEZ, Pedro Romano; PONTE; Pedro Fuzeta da. Garantias gerais de cumprimento. 4. ed. Coimbra: Almedina, 2003, p. 82). 
que, em se tratando de oferta pública de aquisição de controle a ser paga com valores mobiliários, a oferta deverá ser previamente registrada na CVM para ser realizada ${ }^{183}$.

Em relação à oferta pública de aquisição de controle, mediante pagamento com permuta por outros valores mobiliários, o artigo 33 da Instrução CVM nº 361/02 estabelece que "qualquer oferta pública que envolva permuta por valores mobiliários, inclusive as ofertas mistas e alternativas (art. $6^{\circ}$, III e $\S 1^{\circ}$ ), dependerá de registro perante a CVM, na forma do art. $9^{\circ}$, observando-se, ademais, as regras dos arts. $4^{\circ}$ a $8^{\circ}$ e 10 a $12^{\prime \prime}$.

O artigo 33, §1º da Instrução CVM n 361/02 aduz que "somente poderão ser ofertados em permuta valores mobiliários de emissão de companhia aberta, admitidos à negociação em bolsa de valores ou mercado de balcão organizado”, desde que observados determinados requisitos ${ }^{184}$.

Em regra, a oferta pública de aquisição de controle é realizada com o objetivo de adquirir número pré-determinado de ações que assegure ao ofertante o controle da companhia. É, neste sentido, a disposição contida no $\S 2^{\circ}$ do artigo 257 da Lei no 6.404/76, o qual prevê expressamente que, uma vez realizada, a oferta pública é irrevogável ${ }^{185}$ em relação ao proponente.

\footnotetext{
${ }^{183}$ Reforçando o disposto no $\S 1^{\circ}$ do artigo 257 da Lei $n^{\circ} 6.404 / 76$, o $\S 1^{\circ}$ do $\operatorname{artigo} 2^{\circ}$ da Instrução CVM $n^{\circ}$ 361/02 prevê que somente estarão sujeitas a registro perante a CVM as modalidades de OPA de que tratam os incisos IV e V (i.e., respectivamente, OPA voluntária e OPA para aquisição de controle de companhia aberta), quando envolverem permuta por valores mobiliários.

${ }^{184} \mathrm{O} \S 1^{\circ}$ do artigo 33 da Instrução CVM nº 361/02 prevê que "somente poderão ser ofertados em permuta valores mobiliários de emissão de companhia aberta, admitidos à negociação em bolsa de valores ou mercado de balcão organizado, observando-se entretanto o seguinte: (i) caso se trate de OPA por alienação de controle em que o preço pago pelo adquirente envolva bens ou valores mobiliários não admitidos à negociação, e em outras circunstâncias especiais, nas quais fique assegurado tratamento equitativo e adequada informação aos titulares das ações objeto da OPA, a CVM poderá admitir que a oferta pública de permuta ou mista seja liquidada com pagamento em bens ou valores mobiliários não admitidos à negociação, ou não emitidos por companhias abertas; (ii) para os efeitos do disposto neste artigo, equiparam-se às companhias abertas as sociedades estrangeiras emitentes de valores mobiliários, desde que tais valores mobiliários sejam admitidos à negociação em mercado de valores mobiliários submetido à fiscalização da CVM; e (iii) ainda para os efeitos do disposto neste artigo, equiparam-se aos valores mobiliários admitidos à negociação os certificados de ações admitidos à negociação, inclusive aqueles emitidos por instituição financeira autorizada a operar no Brasil, lastreados em valores mobiliários de emissão de sociedades estrangeiras, desde que estas últimas obtenham registro de companhia aberta perante a CVM, na forma da legislação em vigor”.

${ }^{185}$ A irrevogabilidade prevista para a oferta pública não impede a aposição pelo ofertante de condição, suspensiva e/ou resolutiva, subordinando a eficácia da oferta pública a determinado evento. A própria Lei $\mathrm{n}^{\circ}$ 6.404/76 estabelece a condição de que a aquisição compreenda número mínimo de ações da companhia-alvo capaz de atribuir o controle ao ofertante (artigo 258, inciso III). Além disso, o Colegiado da CVM, em decisão unânime sobre a matéria, já consignou entendimento autorizando a aposição de condição à oferta. O
} 
Caso o ofertante já detenha participação acionária na companhia-alvo e realize oferta pública de aquisição de controle, visando a consolidar condição de acionista controlador da companhia, o $\S 3^{\circ}$ do artigo 257 da Lei $n^{\circ}$ 6.404/76 determina que o ofertante deverá fazer prova, perante a CVM, das ações de sua propriedade.

O $\S 4^{\circ}$ encerra o artigo 257 da Lei $n^{\circ}$ 6.404/76 prescrevendo que a CVM poderá expedir normas sobre oferta pública de aquisição de controle, tal como realizado por meio da Instrução CVM nº 361/02.

Por exigência expressa do artigo 258 da Lei $n^{0}$ 6.404/76, o instrumento da oferta pública de aquisição de controle deverá ser firmado pelo ofertante e pela instituição financeira que garante o pagamento, nos termos do artigo 257 da Lei $n^{\circ} 6.404 / 76$, e, em seguida, será publicado na imprensa, devendo indicar: (i) o número mínimo de ações que o ofertante se propõe a adquirir e, se for o caso, o número máximo; (ii) o preço e as condições de pagamento; (iii) a subordinação da oferta ao número mínimo de aceitantes e a forma de rateio entre os aceitantes, se o número deles ultrapassar o máximo fixado; (iv) o procedimento que deverá ser adotado pelos acionistas aceitantes para manifestar a sua aceitação e efetivar a transferência das ações; (v) o prazo de validade da oferta, que não poderá ser inferior a 20 (vinte) dias; e (vi) informações sobre o ofertante.

Tal como examinado no $\S 2^{\circ}$ do artigo 257 da Lei $n^{0}$ 6.404/76, essas ofertas públicas são irrevogáveis em relação ao ofertante e, dada esta característica, associada ao objetivo que se quer alcançar, a oferta é realizada sob a condição suspensiva de que determinado número de acionistas venha a ela aderir ${ }^{186}$. Isto é, se não houver uma adesão mínima, o negócio jurídico proposto pelo ofertante não se torna eficaz, nos termos do artigo 125 do Código Civil.

Diretor Relator na ocasião, Luiz Antonio de Sampaio Campos, com propriedade expôs que "o argumento da Área Técnica de que a oferta deva ser irretratável e que, por isso, não possa ser objeto de condição, não me impressiona [...] também não me impressiona o argumento de que as únicas condições possíveis seriam aquelas constantes da regulamentação, pois tal conclusão é, a meu ver, equivocada, por não decorrer da lei ou do regulamento (onde não há disposição neste sentido), resultando tão-somente da irretratabilidade antes mencionada. É curial para o bom desenlace da questão que se distinga a irrevogabilidade de um ato jurídico e a aposição de condições. Nessa linha, esclareço [...] que, a meu juízo, não há nenhuma incompatibilidade entre a irrevogabilidade ou irretratabilidade de um ato jurídico e a existência de condições” (CVM, Memorando 058/2001, Superintendência de Registro de Valores Mobiliários - SRE, Rel. Dir. Luiz Antonio de Sampaio Campos, 17.07.2001).

${ }^{186}$ CORDEIRO, António Manuel da Rocha e Menezes. Da Tomada de Sociedades (Takeover): Efectivação, Valoração e Técnicas de Defesa. ROA. Lisboa, n. 54, pp. 761-777, 1994, p. 767. 
No que se refere à previsão da forma de rateio entre os aceitantes, se o número deles ultrapassar o máximo fixado no instrumento de oferta, o $\S 3^{\circ}$ do artigo 261 da Lei ${ }^{\circ}$ 6.404/76 prescreve que o rateio será obrigatório, “na forma prevista no instrumento da oferta”.

A quarta exigência diz respeito "ao procedimento que deverá ser adotado pelos acionistas aceitantes para manifestar a sua aceitação e efetivar a transferência das ações”. Neste ponto, o que se quer é que o aceitante saiba quais atos deverá adotar para manifestar sua aceitação e, em seguida, formalizar a compra e venda de ações mediante a transferência das mesmas.

A quinta exigência refere-se ao "prazo de validade da oferta, que não poderá ser inferior a 20 (vinte) dias”. O objetivo é estabelecer cronograma especificando até que data o acionista deverá formalizar sua aceitação à oferta, esclarecendo-se até quando esta vigorará.

A sexta exigência legal é a disponibilização de "informações sobre o ofertante”, a fim de que os aceitantes saibam quem é que está realizando a oferta.

Para além dessas exigências legais mínimas, o ofertante possuirá ampla liberdade na determinação das informações adicionais a serem contempladas no instrumento de oferta, desde que respeitados os preceitos normativos sobre a matéria.

Em relação às ofertas públicas de aquisição de controle, cujo pagamento se dê mediante permuta, o artigo 33, §2º da Instrução CVM n ${ }^{\circ}$ 361/02 prevê exigências adicionais, determinando que o anúncio da oferta contemple também: (i) informações sobre a relação de troca, a quantidade, espécie e classe dos valores mobiliários ofertados, os direitos legais e estatutariamente atribuídos a tais valores, seu histórico de negociação nos últimos 12 (doze) meses, e o tratamento a ser dado às eventuais frações decorrentes da relação de troca, sem prejuízo de outras informações consideradas necessárias pela CVM; (ii) informações sobre a companhia emissora dos valores mobiliários ofertados, na forma exigida pela CVM para a distribuição pública destes valores; e (iii) preço, em reais, calculado segundo a relação de troca proposta. 
Nesse mesmo sentido, o artigo 259 da Lei ${ }^{\circ}$ 6.404/76 determina que o projeto de instrumento de oferta de permuta deverá conter, "além das referidas no artigo 258, informações sobre os valores mobiliários oferecidos em permuta e as companhias emissoras desses valores”.

Uma vez realizada a oferta pública, a mesma deverá ser comunicada à CVM em até 24 horas da primeira publicação do instrumento de oferta, tal como determina o parágrafo único do artigo 258 da Lei $n^{0}$ 6.404/76. Isto é, o que se exige aqui não é nenhuma forma de aprovação e/ou chancela por parte da CVM, mas tão somente a comunicação sobre a realização da oferta.

Caso, porém, o pagamento se dê mediante permuta, o §1º do artigo 257 da Lei $n^{0}$ 6.404/76 determina que a oferta de permuta somente poderá ser efetuada após o prévio registro na CVM.

O parágrafo único do artigo 259 da Lei nº 6.404/76 prevê que a CVM poderá fixar normas sobre o instrumento de oferta de permuta e o seu registro prévio. A este respeito, os $\S \S 3^{\circ}$ e $4^{\circ}$ do artigo 33 da Instrução CVM n ${ }^{\circ}$ 361/02 contemplam exigências a serem atendidas no instrumento da oferta de permuta.

O artigo 260 da Lei $n^{\circ}$ 6.404/76 estabelece que “até a publicação da oferta, o ofertante, a instituição financeira intermediária e a Comissão de Valores Mobiliários devem manter sigilo sobre a oferta projetada, respondendo o infrator pelos danos que causar".

Já o artigo 261 da Lei $n^{\circ}$ 6.404/76, ao tratar do processamento da oferta, determina que "a aceitação da oferta deverá ser feita nas instituições financeiras ou no mercado de valores mobiliários indicadas no instrumento de oferta e os aceitantes deverão firmar ordens irrevogáveis de venda ou permuta, nas condições ofertadas, ressalvado o disposto no $\S 1^{\circ}$ do artigo 262”.

Portanto, o acionista que manifestar aceitação em relação à oferta pública estará fazendo-o em caráter irrevogável, mesmo sabendo que a oferta pública poderá sequer concretizar-se, caso não seja alcançada a adesão mínima a que, na maioria das vezes, estará subordinada. 
É facultado ao ofertante a oportunidade de melhorar, por uma única vez ${ }^{187}$, as condições de preço ou forma de pagamento, “desde que em porcentagem igual ou superior a 5\% (cinco por cento) e até 10 (dez) dias antes do término do prazo da oferta” (artigo 261, $\S 1^{\circ}$ da Lei $n^{0}$ 6.404/76). As novas condições se estenderão aos acionistas que já tiverem aceitado a oferta. A disposição contida no artigo 261, $\S 1^{\circ}$ da Lei $n^{\circ}$ 6.404/76 vem sendo severamente criticada pela doutrina. Luiz Leonardo Cantidiano critica este dispositivo, com as seguintes palavras, que endossamos integralmente:

Até dez dias antes do término do prazo de validade da oferta, é lícito ao ofertante melhorar, uma única vez, as condições de preço ou forma de pagamento, desde que em porcentagem igual ou superior a $5 \%$. Tal previsão, que limita a uma só vez a melhora nas condições da oferta, embora também adotada na França por lei de agosto de 1978, não parece a mais acertada. O melhor, na verdade, é o sistema de livre leilão adotado nos EUA, pelo qual é facultado ao ofertante melhorar, mais de uma vez, as condições de sua proposta original. Se a oferta pública é uma técnica de mercado, e se o mercado deve funcionar, sempre que possível, de forma livre, não existem motivos que impeçam a melhora, por mais de uma vez, das condições da oferta, até porque o beneficiário final é o investidor, que fica habilitado a vender suas ações em condições mais vantajosas $^{188}$.

O §2 ${ }^{\circ}$ do artigo 261 da Lei $n^{\circ}$ 6.404/76 prevê que "findo o prazo da oferta, a instituição financeira intermediária comunicará o resultado à Comissão de Valores Mobiliários e, mediante publicação pela imprensa, aos aceitantes”.

O artigo 262 da Lei $\mathrm{n}^{\circ}$ 6.404/76 disciplina a oferta concorrente, que é de enorme relevância para os propósitos deste trabalho. Tal dispositivo prevê que "a existência de oferta pública em curso não impede oferta concorrente”.

\footnotetext{
${ }^{187}$ Existindo oferta concorrente, "será lícito tanto ao ofertante inicial quanto ao ofertante concorrente aumentarem o preço de suas ofertas tantas vezes quantas julgarem conveniente, desde que de tal aumento deem notícia pública, com o mesmo destaque da oferta”, conforme prescreve o artigo 13 , §3º da Instrução $\mathrm{CVM} \mathrm{n}^{\circ} 361 / 02$.

${ }^{188}$ CANTIDIANO, Luiz Leonardo. Revista da CVM. Rio de Janeiro: Comissão de Valores Mobiliários, v. 3, n. 9, pp. 35-42, set./out. 1985, p. 41.
} 
E, a publicação da oferta concorrente torna nulas ${ }^{189}$ — ou, melhor dizendo, ineficazes, como recomenda Fábio Konder Comparato ${ }^{190}$ — as ordens de venda que já tenham sido firmadas em aceitação de oferta anterior, nos termos do $\S 1^{\circ}$ do artigo 262 da Lei ${ }^{\circ} 6.404 / 76$.

Por sua vez, o $\S 2^{\circ}$ do artigo 262 da Lei ${ }^{\circ}$ 6.404/76 estabelece que “é facultado ao primeiro ofertante prorrogar o prazo de sua oferta até fazê-lo coincidir com o da oferta concorrente”.

A CVM poderá expedir normas que disciplinem a negociação das ações objeto da oferta durante o seu prazo (artigo 263 da Lei $n^{\circ}$ 6.404/76).

A Lei $n^{\circ}$ 6.404/76 é reconhecida na doutrina como um “incontestável progresso legislativo" ${ }^{191}$ no que tange às ofertas públicas.

Nos países em que há intensa dispersão acionária nas companhias abertas, as disputas pelo controle acionário são responsáveis pela criação de importantes oportunidades de negócios ${ }^{192}$. Nos EUA, por exemplo, as disputas no âmbito do mercado para o controle societário (market for corporate control) têm lugar central na disciplina do

\footnotetext{
${ }^{189}$ Modesto Carvalhosa faz duras críticas, a nosso ver acertadamente, ao vício de nulidade prescrito pelo artigo 262 da Lei n ${ }^{\circ} 6.404 / 76$, nos seguintes termos: "No que respeita aos efeitos da oferta concorrente sobre as ordens de aceitação já produzidas no âmbito da oferta pública original, o legislador as considera 'nulas'. Essa expressão jurídica não pode ser mais inapropriada. A nulidade presume inobservância insanável de lei, ou seja, de antijuridicidade absoluta. [...] É inadmissível que o legislador tenha estabelecido que a publicação de oferta concorrente torna nulas as ordens de venda que já tenham sido firmadas [...]. Ocorrendo oferta pública concorrente, sua publicação torna ineficazes as ordens de venda já dadas. Tal fato jurídico superveniente nem sequer atinge a validade da ordem de aceitação anteriormente dada" (CARVALHOSA, Modesto. Comentários à Lei de Sociedades Anônimas. v. 4, t. II, 2. ed. rev. e atual. São Paulo: Saraiva, 2003, p. 259).

${ }^{190}$ COMPARATO, Fábio Konder; SALOMÃO FILHO, Calixto. O Poder de Controle na Sociedade Anônima. 4. ed. Rio de Janeiro: Forense, 2005, p. 259.

${ }^{191}$ Ibid., p. 259.

192 ALLEN, William T.; KRAAKMAN, Reinier. Commentaries and Cases on the Law of Business Organization. Nova York: Aspen Publishers, 2003, p. 497. Confira-se também: ROMANO, Roberta (coord.). Foundations of Corporate Law. 2. re-imp. Nova York: Foundation Press, 2004, p. 221.
} 
direito societário. As ofertas públicas de aquisição de controle desempenham papel principal nestas disputas pelo controle, fomentando a existência de mercado interessado na aquisição de ações representativas do controle de companhia aberta com dispersão acionária.

No Reino Unido, as takeover bids são operações indissociáveis do cotidiano das grandes companhias, sendo utilizadas, com relativa frequência, em negócios destinados à assunção de poder de controle sobre companhias e transferências de ativos. O sistema jurídico do Reino Unido, em operações de tomada de controle, centra-se nas regras de auto-regulação do City Code, atribuindo grande liberdade ao mercado de capitais e aos empresários em geral.

A oferta pública de aquisição de controle é o mecanismo clássico aplicado nas tomadas de controle hostil de companhias abertas. Quando há resistência à aquisição de controle por parte dos administradores e/ou determinados acionistas relevantes, em cenário de dispersão acionária, tal instrumento revela-se eficiente, pois permite a realização da operação diretamente com os acionistas detentores de ações dispersas no mercado, por operação pública, independentemente de aprovação dos órgãos sociais.

São as companhias abertas estruturadas com dispersão acionária que, potencialmente, estão suscetíveis às tomadas de controle, via oferta pública, e é justamente nestas companhias que, geralmente, os órgãos de administração estão dotados de maior liberdade, uma vez que não há o contínuo e direto monitoramento dos administradores pelo acionista controlador ${ }^{193}$.

Calixto Salomão Filho alerta que "a maior liberdade atribuída a administradores de uma companhia sem controlador definido é responsável por preocupações doutrinárias. Na literatura norte-americana essas preocupações são externadas por meio da expressão agency costs (ou custos de monitoramento)”194.

\footnotetext{
193 JENSEN, Michael C.; MECKLING, W. Theory of the Firm: Managerial Behavior. Agency Cost, and Ownership Structure. Journal of Financial Economics. v. 3, n. 4, 1976, pp. 305-360. Disponível em $<$ http://papers.ssrn.com/abstract=94043>. Acesso em 12.12.2009.

194 SALOMÃO FILHO, Calixto. Diluição de Controle. In: . O Novo Direito Societário. 3. ed. São Paulo: Malheiros, 2006, p. 68.
} 
Os agency costs (ou custos de monitoramento) são decorrentes do problema de agência inerente à relação entre os administradores da companhia-alvo e os seus acionistas, na iminência da adoção contra esta última de uma oferta pública para a aquisição de ações representativas de seu controle.

Henry Hansmann e Reinier R. Kraakman lecionam que o problema de agência ocorre sempre que o bem-estar de uma parte, referida como “principal”, depende de ações por parte de outra, referida como "agente"195.

Nas organizações empresariais tais problemas são verificados, especialmente, nas seguintes situações: (i) conflito entre os proprietários das participações na sociedade e os administradores da sociedade; (ii) conflito entre os acionistas controladores e as minorias ou acionistas não controladores; e (iii) conflito entre a sociedade e terceiros com quem esta mantém relações jurídicas (stakeholders), tais como credores, trabalhadores e consumidores $^{196}$.

Quando a companhia-alvo é submetida à oferta para a aquisição de seu controle, o interesse dos administradores em se manterem nos seus cargos pode acarretar conflito com os interesses dos acionistas, que podem estar interessados em alienar suas ações, uma vez que, normalmente, em alterações de controle, segue-se a substituição dos administradores por outros indicados pelo adquirente do controle.

Portanto, as ofertas públicas de aquisição de controle são aplicáveis às companhias dotadas de dispersão acionária, que, em decorrência de tal característica organizacional, possuem órgãos de administração com maior liberdade em relação aos acionistas. Este aspecto pode suscitar inúmeros conflitos, uma vez que as tentativas de tomada de controle podem ocorrer em meio a problemas de agência entre os administradores e os acionistas da companhia-alvo.

\footnotetext{
${ }^{195}$ Henry Hansmann e Reinier R. Kraakman anotam: “[the agency problem] arises whenever the welfare of one party, termed 'principal,' depends upon actions to be taken by another party, termed the 'agent"” (HANSMANN, Henry; KRAAKMAN, Reinier. Agency Problems and Legal Strategies. In: KRAAKMAN, Reinier et al. The Anatomy of Corporate Law: A Comparative and Functional Approach. Oxford: Oxford University Press, 2004, p. 21). Ver também o destaque que é dado à questão por Roberta Romano (ROMANO, Roberta [coord.]. Foundations of Corporate Law. 2. re-imp. Nova York: Foundation Press, 2004, p.221).

${ }^{196}$ HANSMANN, Henry; KRAAKMAN, Reinier. Op. cit., p. 22.
} 
As tomadas de controle de companhias abertas usualmente envolvem montantes elevados. A oferta pública é normalmente realizada por valor que seja atraente aos acionistas da companhia-alvo, conforme examinado no item 4.8, e há a necessidade de que sejam adquiridas ações em número suficiente para assegurar o controle pelo ofertante.

Por inúmeras razões, é comum a adoção de esquemas de financiamento para que o ofertante realize a tomada de controle da companhia-alvo, mediante a utilização de recursos próprios ou de terceiros ${ }^{197}$.

\subsubsection{RECURSOS Próprios}

Como se infere do próprio nome dessa modalidade de financiamento, o ofertante suporta todos os custos e despesas para a tomada do controle, com os seus próprios recursos.

A tomada de controle realizada com recursos próprios é a modalidade mais simples e tradicional, mas, por razões financeiras, tende a ser menos frequente do que a tomada de controle realizada com recursos de terceiros. Dificilmente o ofertante possui os recursos necessários à tomada de controle e os mantém não aplicados e disponíveis para tal operação.

${ }^{197}$ CORDEIRO, António Manuel da Rocha e Menezes. Da Tomada de Sociedades (Takeover): Efectivação, Valoração e Técnicas de Defesa. ROA. Lisboa, n. 54, pp. 761-777, 1994, p. 768. 
Na experiência internacional, são frequentes as tomadas de controle de companhias abertas realizadas por meio de operações estruturadas, nas quais o ofertante é financiado por terceiros.

Chamam-se de leveraged buyout ("LBO”) ${ }^{198}$ as operações de aquisição de controle realizadas quando uma parcela significativa dos recursos utilizados para o pagamento das ações adquiridas é financiado através de dívida assumida pelo ofertante. Diz-se, então, que a tomada de controle será empreendida com endividamento.

A aquisição de controle, por LBO, é aquela realizada quando os recursos necessários à operação são obtidos pelo ofertante por meio de financiamento de terceiros, usualmente instituições financeiras que emprestam recursos ao ofertante com a perspectiva de participarem de eventuais ganhos, em caso de êxito na tentativa de tomada de controle da companhia-alvo ${ }^{199}$.

Por razões didáticas, os LBOs e os management buyouts (“MBO”) serão analisados, em separado, neste trabalho, a fim de evidenciar as distinções entre estas duas modalidades de tomada de controle viabilizadas financeiramente por meio de endividamento.

Os LBOs clássicos são gênero ${ }^{200}$, do qual os MBOs são espécie, tendo como distinção básica o fato de que os MBOs são LBOs em que o(s) ofertante(s) é(são) membro(s) da administração da companhia-alvo.

\footnotetext{
${ }^{198}$ Inexistindo em nosso vernáculo, a nosso ver, terminologia capaz de traduzir com precisão o conceito da expressão leveraged buyout (LBO) com o significado que lhe é empregado, nos licenciaremos neste trabalho para utilizar tal terminologia em inglês, homenageando a forma adotada pela prática empresarial para designar tal operação.

${ }^{199}$ Para maiores detalhes sobre a importância das estruturas de endividamento em operações de tomada de controle, referir-se a MUELLER, Holger M.; PANUNZI, Fausto. Tender Offers and Leverage. New York

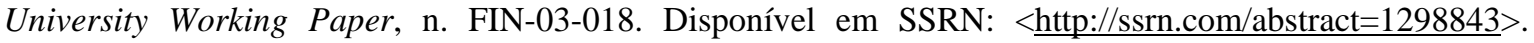
Acesso em 12.12.2009.

${ }^{200}$ Dentro do gênero dos leveraged buyouts (LBO) a doutrina norte-americana menciona ainda os employee buyouts (EBO) em que a aquisição de determinada companhia é realizada por seus empregados e
} 


\subsubsection{LBO - LEVERAGED BUYOUT}

A técnica do $\mathrm{LBO}^{201}$ busca viabilizar financeiramente a aquisição do controle da companhia-alvo pelo ofertante e tem como característica "a transferência dos custos e despesas de aquisição para a sociedade adquirida, mediante a assunção por esta de uma dívida contraída para a sua aquisição"202.

Os LBO são operações de aquisição estruturadas, a fim de assegurar que o desembolso realizado pelo ofertante, por conta da aquisição das ações representativas do controle da companhia-alvo, será recompensado quando da efetiva obtenção do controle desta companhia.

Nos LBOs pretende-se transferir os custos e despesas da aquisição para a própria companhia-alvo, a fim de que o pagamento do endividamento obtido pelo ofertante para empreender a tomada de controle possa ser realizado com recursos gerados pela própria companhia recém-adquirida.

A estratégia típica de realização de tomada de controle por LBO consiste em utilizar uma sociedade-veículo, que não possua ativos ou passivos com valores expressivos, para realizar a oferta pública de aquisição da companhia-alvo. A sociedadeveículo assumirá endividamento em montante correspondente aos custos e despesas a serem suportados com a referida oferta pública destinada à tomada de controle.

Em seguida, após o ofertante adquirir o controle da companhia-alvo, a sociedade-veículo é usualmente incorporada pela companhia-alvo, de modo que o endividamento assumido para a aquisição das ações representativas do controle será

trabalhadores em geral, utilizando-se de recursos derivados de planos de opção de compra (employee stock option plans - ESOP).

${ }^{201}$ Veja-se a obra dos autores norte-americanos Melvin A. Eisenberg e Willian L. Cary, segundo os quais o "leveraged buyout is a combination of a management buyout and high degree of leverage" (EISENBERG, Melvin Aron; CARY, William L. Corporations: Cases and Materials. 7. ed. Nova York: Foundation Press, 1995, p. 805).

${ }^{202}$ OSÓRIO, José Diogo Horta. Da Tomada do Controlo de Sociedades (takeovers) por Leveraged Buy-Out e sua Harmonização com o Direito Português. Coimbra: Almedina, 2001, p. 9. 
transferido para a própria companhia-alvo, que passará a ser a sucessora universal da sociedade-veículo, recém-incorporada, nos termos do artigo 227 da Lei nº 6.404/76.

São frequentes os LBOs obtidos pelo ofertante mediante promessa de prestação de garantias com bens e/ou direitos da companhia-alvo, com previsão de que após a tomada de controle o fluxo de caixa da companhia-alvo ou determinados elementos do ativo desta última servirão para assegurar a quitação do financiamento ${ }^{203}$. As garantias prestadas com ativos da companhia-alvo podem ter como consequência sua descapitalização ${ }^{204}$.

A utilização dos LBOs no Brasil encontra limites próprios de nosso sistema jurídico, embora sejam usuais aquisições de controle associadas à obtenção de endividamento pelo comprador.

Certo é que a estratégia típica dos LBOs, consistente na utilização de uma sociedade-veículo para realizar a oferta pública de aquisição de ações, com assunção de endividamento e previsão de que após a aquisição será subsequentemente incorporada pela companhia-alvo, suscita questionamentos concretos entre nós.

O artigo 117, §1 ${ }^{\circ}$, alínea “b”, da Lei n ${ }^{\circ} 6.404 / 76^{205}$ prevê como abuso do poder de controle "promover [...] transformação, incorporação, fusão ou cisão da companhia, com o fim de obter, para si ou para outrem, vantagem indevida, em prejuízo dos demais acionistas, dos que trabalham na empresa ou dos investidores em valores mobiliários emitidos pela companhia”.

O acionista que houver recém-adquirido o poder de controle com a oferta pública estará incorporando na companhia-alvo uma sociedade-veículo endividada, visando a satisfazer interesse individual que poderá, inclusive, se revelar conflitante com o interesse social. Portanto, aplicar-se-ia ao caso o disposto no artigo 115 , $\S 1^{\circ}$, da Lei $\mathrm{n}^{\circ}$

\footnotetext{
${ }^{203}$ José Diogo Horta Osório expõe que há leveraged buyouts realizados "contando-se com os fundos da empresa a adquirir para pagar o preço a sua própria aquisição - seja o seu cash flow futuro, sejam as reservas, ou o produto da alienação de bens do seu ativo" (OSÓRIO, José Diogo Horta. Da Tomada do Controlo de Sociedades (takeovers) por Leveraged Buy-Out e sua Harmonização com o Direito Português. Coimbra: Almedina, 2001, p. 112).

${ }^{204}$ CORDEIRO, António Manuel da Rocha e Menezes. Da Tomada de Sociedades (Takeover): Efectivação, Valoração e Técnicas de Defesa. ROA. Lisboa, n. 54, pp. 761-777, 1994, pp. 769-770.

${ }^{205} \mathrm{O}$ artigo 15, inciso II, da Instrução CVM no 319/99 contém disposição no mesmo sentido.
} 
6.404/76, com as consequências do $\S 4^{\circ}$ do referido dispositivo, se restar configurado o conflito de interesses. O acionista controlador também responderia pelos danos causados, nos termos do artigo 117 da Lei ${ }^{\circ}$ 6.404/76, mormente se caracterizadas as hipóteses previstas nas alíneas “a” e “b” do referido dispositivo legal.

Obviamente, estratégias de tomada de controle viabilizadas financeiramente com recursos de terceiros podem e são utilizadas no Brasil. Entretanto, as estruturas para serem aplicadas no Brasil devem ser compatibilizadas e repensadas para que não lhes sejam aplicáveis regras restritivas e vedações típicas do nosso sistema jurídico.

\subsubsection{MBO - MANAGEMENT BUyouT}

O MBO consiste na tomada de controle da companhia-alvo, realizada por seus próprios administradores, em conjunto ou isoladamente, mediante financiamento de terceiros. Trata-se de subespécie de LBO, na qual o(s) ofertante(s) é(são) membro(s) da administração da companhia-alvo.

Mediante a realização de $\mathrm{MBO}$, os administradores pretendem ser os protagonistas da mudança do controle da companhia-alvo, realizando investimento potencialmente baixo, e valendo-se de estrutura de endividamento a ser suportado, na maioria dos casos, pela própria companhia-alvo, após a conclusão da tomada de controle.

Os EUA presenciaram na década de 1980 inúmeros e frequentes MBOs. Sofisticadas técnicas financeiras possibilitaram a concepção de muitas estruturas de endividamento, que, em alguns casos, foram adotadas pelos próprios administradores de companhias com dispersão acionária, a fim de tomarem o controle destas últimas.

O caso mais emblemático para o estudo dos MBOs na doutrina norteamericana é a operação, realizada em 1988, na qual o Diretor Presidente da RJR Nabisco, Inc. (Ross Johnson) e alguns membros da administração realizaram oferta pública para aquisição do controle de tal companhia. Diante da oferta pública, inúmeros grupos de investidores realizaram ofertas concorrentes, que culminaram com a aquisição do controle 
da RJR Nabisco pelo grupo de investidores liderado pela Kohlberg Kravis Roberts \& Co. (KKR), em operação envolvendo aproximadamente US\$ 25.000.000.000,00 (vinte e cinco bilhões de dólares) ${ }^{206}$.

Os MBOs apresentam especificidades em relação aos LBOs, sobretudo diante do fato de que os ofertantes são os membros da administração da companhia-alvo.

Em regra, em companhias abertas com dispersão acionária, os administradores da companhia-alvo são quem melhor conhecem as condições operacionais, contábeis, econômicas e financeiras da companhia-alvo. Usualmente, não há, como nas companhias abertas com concentração acionária, a figura do acionista controlador que orienta e acompanha de perto as atividades da companhia. Em alguns casos, geralmente os administradores utilizam-se do fluxo de caixa da companhia-alvo para financiar a tomada de controle que pretendem empreender.

O autor português José Diogo Horta Osório pondera que no MBO há patente conflito de interesses, pois "os representantes do management actuam simultaneamente como agentes dos vendedores e como compradores da empresa, portanto, prosseguindo interesses contrapostos”207.

Há uma linha tênue a ser potencialmente transposta pelos membros da administração da companhia-alvo, que serão, ao mesmo tempo, os ofertantes e, de certa forma, deverão auxiliar os acionistas da companhia-alvo na avaliação quanto à oferta pública recebida.

\footnotetext{
${ }^{206}$ Em 1988, alguns anos depois da fusão entre a indústria de tabaco R.J. Reynolds e a indústria de gêneros alimentícios Nabisco, o presidente da entidade resultante (RJR Nabisco), Ross Johnson, anunciou que ele e demais membros da administração pretendiam adquirir o controle da RJR Nabisco e, em seguida, retirá-la de negociação em bolsa de valores. Tal aquisição a ser potencialmente empreendida por membros da administração da RJR Nabisco havia sido planejada e estruturada valendo-se de mecanismos, modernos à época, de financiamento da aquisição (em estratégia clássica de $M B O$ - Management Buyout). O valor originalmente proposto por cada ação da RJR Nabisco era de aproximadamente US\$ 50,00 dólares. Várias ofertas concorrentes se seguiram, acabando a RJR Nabisco por ser vendida meses mais tarde à Kohlberg Kravis Roberts \& Co (KKR), ao valor de US\$ 109,00 (cento e nove dólares) por ação. A aquisição da RJR Nabisco pela KKR montou em aproximadamente US\$ 25.000.000.000,00 (vinte e cinco bilhões de dólares). Até os dias de hoje, tal operação representa um dos maiores leveraged buyout (LBO) registrados na história, em termos de volume de recursos financeiros envolvidos. Para maiores informações sobre este interessante caso, referir-se a BURROUGH, Bryan e HELYAR, John. Barbarians At The Gate: The Fall Of RJR Nabisco. Nova York: Harper \& Row, 1990.

${ }^{207}$ OSÓRIO, José Diogo Horta. Da Tomada do Controlo de Sociedades (takeovers) por Leveraged Buy-Out e sua Harmonização com o Direito Português. Coimbra: Almedina, 2001, p. 37.
} 
Além disso, deve-se ter cuidado com a violação de deveres legais dos administradores e quanto à existência de informações privilegiadas, não acessíveis ao mercado em geral, detidas pelos administradores em tais operações. António Menezes Cordeiro $^{208}$ pondera pela possibilidade de haver uso, pela administração, de informações privilegiadas como vantagem competitiva em relação ao mercado em geral, recomendando especial cuidado a fim de evitar transgressões capazes de gerar graves perturbações ao mercado de capitais.

Os MBOs são, em muitos casos, inconciliáveis com os deveres atribuídos pela legislação societária brasileira aos seus administradores. Tratando-se os MBOs de uma espécie dos LBOs, repliquem-se aqui as nossas considerações do item 4.6.2.1 quanto à adoção de LBOs no Brasil e algumas das restrições de nossa legislação.

\section{ESCOLHA DA COMPANHIA-ALVO}

O processo de escolha da companhia-alvo está estreitamente relacionado à finalidade da aquisição, levando-se sempre em conta, dentre outros, critérios econômicos, financeiros e de mercado que orientam o ofertante a destinar sua oferta pública aos acionistas da companhia cujo controle se pretenda adquirir.

Robert Clark ${ }^{209}$ ensina que as razões mais comuns pelas quais são feitas ofertas públicas de aquisição de controle são a expectativa de potenciais ganhos resultantes da melhor administração, ganhos de sinergia, aspectos concorrenciais, benefícios para a administração e ganhos decorrentes do desmantelamento da companhia-alvo subsequente à sua aquisição ${ }^{210}$.

${ }^{208}$ CORDEIRO, António Manuel da Rocha e Menezes. Da Tomada de Sociedades (Takeover): Efectivação, Valoração e Técnicas de Defesa. ROA. Lisboa, n. 54, pp. 761-777, 1994, p. 769.

${ }^{209}$ CLARK, Robert Charles. Corporate Law. Boston / Toronto: Little, Brown and Company, 1986, pp. 533539.

${ }^{210}$ As explicações da ocorrência das ofertas públicas de aquisição deixam claro que a matéria pode ter relevância para o direito concorrencial. Há hipóteses em que a aquisição do controle de determinada companhia-alvo visa a, basicamente, eliminar um concorrente do ofertante no mercado em que este último 
Costuma-se dizer que as tomadas de controle podem ser realizadas com base em fundamentos econômicos ou financeiros. As tomadas de controle econômicas caracterizam-se por visarem à obtenção ou ao aproveitamento de sinergias "procurando aumentar as acções, a influência e os lucros do grupo, através de laboração concertada subsequente” 211 . Por outro lado, as tomadas de controle financeiras são realizadas considerando a companhia-alvo apenas como um “objecto de lucro imediato: a ideia será de proceder ao seu desmantelamento, de modo a alcançar lucros imediatos”212. António Menezes Cordeiro pondera que as tomadas de controle financeiras são condenáveis, porque acarretam destruição de riquezas, com prejuízos sociais, em sua opinião, traduzindo-se, apenas, em ganhos primários e não sendo, assim, admitidos na Europa ${ }^{213}$.

A escolha da companhia-alvo também leva em consideração a análise do valor de cotação de suas ações e ponderações sobre a eficiência do papel desempenhado por sua administração. Nesta hipótese, o ofertante está potencialmente interessado em adquirir a companhia-alvo que, em seu entendimento, poderá gerar melhores resultados e ter a cotação de suas ações majorada com uma administração mais eficiente.

As lições de Roberta Romano são neste mesmo sentido, prevendo que:

[...] the lower the stock price, relative to what it could be with more efficient management, the more attractive the takeover become to those who believe that they can manage the company more efficiently. And the potential returns from the successful takeover and revitalization of a poorly run company can be enormous $[\ldots]^{214}$.

A companhia aberta, que esteja sob administração ineficiente, sem gerar retornos para os seus acionistas da maneira como poderia fazê-lo, tende a ter o valor de cotação de suas ações em bolsa de valores reduzido. Portanto, de maneira geral, há o

atua. Sendo assim, é importante identificar os motivos pelos quais está sendo realizada a tomada de controle, de modo a evitar práticas contrárias às normas de direito concorrencial.

${ }^{211}$ CORDEIRO, António Manuel da Rocha e Menezes. Da Tomada de Sociedades (Takeover): Efectivação, Valoração e Técnicas de Defesa. ROA. Lisboa, n. 54, pp. 761-777, 1994, p. 768.

212 Ibid., p. 768.

213 Ibid., p. 768.

${ }^{214}$ ROMANO, Roberta (coord.). Foundations of Corporate Law. 2. re-imp. Nova York: Foundation Press, 2004, p. 224. 
entendimento de que as companhias abertas com dispersão acionária, em que os resultados apresentados estão abaixo da expectativa e, em alguns casos, impactando na própria cotação em bolsa de suas ações, tendem a ser mais suscetíveis às tentativas de tomada de controle.

As ofertas públicas de aquisição de controle e o mercado para o controle (market for corporate control) potencialmente associado a elas desempenham papel fundamental no sentido de disciplinar a administração de companhias abertas com dispersão acionária a ser eficiente ${ }^{215}$.

Ainda em relação à escolha da companhia-alvo, a existência de medidas defensivas contra tomadas de controle funciona como inibidor para tentativas de tomada de controle. O ofertante tende a priorizar a tomada de controle de companhias que estejam mais vulneráveis ao takeover, ao invés de empreender maiores esforços, gastar recursos mais elevados e consumir mais tempo para concretizar a tomada de controle de determinada companhia-alvo protegida por medidas defensivas.

Jesse Choper, John Coffee Jr e Ronald Gilson ${ }^{216}$ escrevem sobre outro elemento que pode ser determinante na escolha da companhia-alvo em hipótese na qual os administradores da companhia adquirente, primando por interesses pessoais em administrar uma companhia maior e menos suscetível às tomadas de controle, optam por realizar oferta pública de determinada companhia-alvo. O propósito é formar uma companhia resultante tão grande que não seja atraente para operações de tomada de controle, principalmente por razões financeiras, em virtude do astronômico valor necessário para conclusão de eventual takeover da referida companhia resultante.

Tal fundamento para a escolha da companhia-alvo visando à realização de oferta pública de aquisição de controle nos parece desalinhado com os deveres que devem presidir a atuação dos administradores de companhias.

\footnotetext{
${ }^{215}$ Henry G. Manne destaca a importância da correlação entre a eficiência da administração da companhiaalvo e o valor de suas ações na prática dos takeovers (MANNE, Henry G. Mergers and the Market for Corporate Control. In: ROMANO, Roberta [coord.]. Foundations of Corporate Law. 2. re-imp. Nova York: Foundation Press, 2004, p. 224).

${ }^{216}$ Conforme ensinam Jesse Choper; John Coffee Jr. e Ronald Gilson, “managers of the acquiring corporation may favor an acquisition only because they prefer to run a larger, more stable corporation even at the cost of lower profits" (CHOPER, Jesse H.; COFFEE Jr., John C.; e GILSON, Ronald J. Cases and materials on corporations. 7. ed. Nova York: Aspen Publishers, 2008, p. 938).
} 
O preço da oferta pública de aquisição tende sempre a ser mais elevado do que o valor de cotação de bolsa das ações que se pretende adquirir.

Em uma economia de mercado, os bens tendem a ser comprados e vendidos quando possuem valores diferentes para as partes interessadas. Em processo de alocação eficiente de recursos, os bens são detidos por quem os avalia de modo mais elevado, presumivelmente por entender que os mesmos podem ser utilizados de modo mais hábil.

É assim que funciona a dinâmica do mercado de capitais em relação às ofertas públicas de aquisição de controle. O ofertante, provavelmente, avaliará as ações objeto da oferta por valor acima daquele que os então acionistas proprietários de tais ações o farão.

A concepção é a de que o ofertante poderá utilizar-se de tais bens de modo mais eficiente, em regra por agregar quantidade de ações que lhe garantirá o controle em relação à companhia-alvo. Desta forma, a avaliação conjunta das ações que assegurarão o controle tende a ser superior ao somatório de cada uma destas ações individualmente consideradas.

Além disso, há explicações financeiras que sugerem que a oferta pública não será aceita pelos acionistas da companhia-alvo a menos que seja feita por valor superior ao existente no mercado de capitais, refletindo o preço de propostas potencialmente competitivas. Por outro lado, razões econômicas indicam que o ofertante não realizará a oferta pública se não acreditar que poderá utilizar a companhia-alvo de modo eficiente o bastante para tornar lucrativo o ágio que será pago na aquisição do controle da sociedade $^{217}$.

\footnotetext{
${ }^{217}$ Frank H. Easterbrook e Daniel R. Fischel argumentam que "investors won't tender unless the offer is higher than the one prevailing in the market (which reflects the price of potentially competitive bids); bidders won't make such offers unless they believe they can use the target's assets well enough to make the premium payment profitable [...]" (EASTERBROOK, Frank H.; FISCHEL, Daniel R. The Economic Structure of Corporate Law. Paperback Edition, Massachusetts: Harvard University Press, 1996, p. 162).
} 
O valor global da oferta pode variar em razão da companhia cujo controle se pretenda adquirir. Em princípio, nas companhias em que o capital social é extremamente disperso, o número de ações necessárias para a obtenção do controle tende a ser menor do que nas companhias em que o capital social não é tão disperso. Por razões óbvias, o valor global da oferta será menor quando a quantidade de ações a ser adquirida for menor.

Quando há concorrência em relação à aquisição da companhia-alvo, os ofertantes interessados em adquirir o seu controle tendem a elevar os preços oferecidos ao mercado, a fim de estimular a adesão à sua respectiva oferta. Ou seja, as ofertas concorrentes tendem a aumentar os preços oferecidos ao mercado. A este respeito, é importante lembrar que o artigo 12, §5º da Instrução CVM n 361/02 exige que "quando se tratar de oferta paga à vista, a oferta concorrente deve ser no mínimo 5\% superior o valor da oferta original”.

Os preços propostos em ofertas públicas de aquisição tendem a ser sempre majorados quando a operação não é concretizada rapidamente, de modo a se manterem atrativos aos acionistas da companhia-alvo ou mesmo para superarem outros valores propostos por concorrentes igualmente interessados na aquisição do controle da companhia-alvo. Neste sentido, o artigo 13, §3º da Instrução CVM nº 361/02 estabelece que “uma vez lançada uma OPA concorrente, será lícito tanto ao ofertante inicial quanto ao ofertante concorrente aumentarem o preço de suas ofertas tantas vezes quantas julgarem conveniente, desde que de tal aumento dêem notícia pública, com o mesmo destaque da oferta" $^{218}$.

Entretanto, por razões financeiras ${ }^{219}$, o ofertante tende a abandonar as tentativas de tomada de controle quando o preço da oferta se torna demasiadamente elevado, especialmente nos casos em que o potencial adquirente realiza a tomada de

\footnotetext{
${ }^{218}$ Importante destacar que, se não houver oferta concorrente, o ofertante só poderá melhorar, por uma única vez, as condições de preço ou forma de pagamento propostas e "desde que em porcentagem igual ou superior a 5\% (cinco por cento) e até 10 (dez) dias antes do término do prazo da oferta" (artigo 261, §1 ${ }^{\circ}$ da Lei ${ }^{\circ}$ 6.404/76).

${ }^{219}$ No item 4.7 tratamos dos fundamentos econômicos ou financeiros que motivam o takeover. As tomadas de controle financeiras são aquelas realizadas com o objetivo de lucro imediato, mediante o desmantelamento da companhia-alvo. Em tais casos, a operação é realizada com a subsequente negociação dos principais ativos da companhia-alvo, visando à vantagem financeira para o ofertante. A tomada de controle, em tal hipótese, perde o fundamento quando o preço de compra está elevado.
} 
controle interessado em obter ganhos financeiros futuros com negociações posteriores envolvendo a companhia-alvo ${ }^{220}$.

${ }^{220}$ Os autores norte-americanos Michael C. Jensen e Richard S. Ruback alertam que "wealth-maximizing bidders will abandon takeovers attempts when increments in the offer price would make the takeover a negative present value investment" (JENSEN, Michael C.; RUBACK, Richard S. The Market for Corporate Control: the scientific evidence. In: ROMANO, Roberta [coord.]. Foundations of Corporate Law. 2. re-imp. Nova York: Foundation Press, 2004, p.239). 
No Brasil, são comuns referências equivocadas à expressão poison pill ${ }^{221}$ tal como se esta fosse um sinônimo genérico aplicável a todas as espécies de medidas defensivas contra takeovers hostis ${ }^{222}$.

Na realidade, a poison pill é apenas uma espécie, talvez a mais famosa, do gênero das medidas defensivas (takeover defenses), que são também conhecidas como medidas “afasta-tubarão” (shark repellents) ${ }^{223}{ }^{224}$ ou disposições “porco-espinho” (porcupine provisions) $^{225}$.

A adoção de medidas defensivas contra tomadas de controle hostis é tema de grande importância nos EUA e no Reino Unido, que são países com mercados de capitais reconhecidamente desenvolvidos e com grande número de companhias com estrutura de capital disperso. O assunto suscita interessantes discussões quanto às diferenças de tratamento entre tais países ${ }^{226}$. Em alguns países da Europa Continental, no Brasil e em outros países que vêm apresentando desenvolvimento de seus respectivos mercados de capitais, com crescente dispersão acionária em companhias abertas, a questão torna-se cada vez mais importante.

${ }^{221}$ De acordo com o Black’s Law Dictionary, a expressão poison pill significa “a corporation's defense against an unwanted takeover bid whereby shareholders are granted the right to acquire equity or debt securities at a favorable price to increase the bidder's acquisition costs” (GARNER, Bryan A. Black's Law Dictionary. 4. ed. Saint Paul: West Group, 2001, verbete “poison pill”, p. 1177).

${ }^{222}$ Francisco Antunes Maciel Müssnich e Fábio Henrique Peres fazem um alerta quanto à utilização inadequada da expressão poison pill no Brasil (MÜSSNICH, Francisco Antunes Maciel; PERES, Fábio Henrique. Administração deve colaborar para o melhor uso das poison pills. Disponível em http://www.bmalaw.com.br/nova_internet/arquivos/Artigos/Numero\%2025.pdf>. Acesso em 12.12.2009).

${ }^{223}$ De acordo com o Black's Law Dictionary, a expressão shark repellent significa "a measure taken by a corporation to discourage hostile takeover attempts. Examples include issuing new shares of stock, acquiring expensive assets, and adopting a poison-pill defense" (GARNER, Bryan A. Op. cit., verbete "shark repellent”, p. 1381).

${ }^{224}$ A terminologia shark repellents (repelentes de tubarões) ou shark attack repellents (repelentes de ataques de tubarões) adotada para as medidas defensivas contra tomadas de controle hostis é utilizada em referência aos ofertantes hostis (raiders) como sendo tubarões. São métodos capazes de manter os tubarões afastados, dificultando potenciais ataques.

${ }^{225}$ De acordo com o Black's Law Dictionary, a expressão porcupine provision significa "a clause in a corporation's charter or bylaws designed to prevent a takeover without the consent of the board of directors". (GARNER, Bryan A. Op. cit., verbete “porcupine provision”, p. 1181).

${ }^{226}$ DAVIES, Paul; HOPT, Klaus J. Control Transactions. In: KRAAKMAN, Reinier et al. The Anatomy of Corporate Law: A Comparative and Functional Approach. Oxford: Oxford University Press, 2004, p. 164. 
Discute-se se a adoção de medidas defensivas é, efetivamente, mecanismo destinado a proteger a companhia-alvo e a pluralidade de seus acionistas ou se, na realidade, estas proteções abrangem apenas os administradores contra uma possível destituição, permitindo que se protejam em seus cargos, tal como “trincheiras”, mantendose em suas posições na administração, ameaçadas em caso de mudança de controle ${ }^{227}$.

Há, também, a reflexão de que as medidas defensivas aumentam o custo de aquisição das ações de determinada companhia, mesmo quando se trata de aquisições amigáveis, e podem afugentar bons investidores ou reduzir os valores das ações das companhias defendidas ${ }^{228}$.

Além disso, discute-se se a vulnerabilidade à tomada de controle nas companhias dotadas de dispersão acionária não é um incentivo importante para que a administração de tais companhias, reconhecidas como alvos da tentativa de tomada de controle, mantenha-se eficiente, com o objetivo maior de refletir esta eficiência na majoração do valor de cotação em bolsa de valores das ações de tal companhia. A valorização da cotação tende a dificultar a tomada do controle da companhia-alvo. A estabilização das estruturas de controle, por meio das medidas defensivas pode funcionar,

\footnotetext{
${ }^{227}$ A utilização inadequada de medidas defensivas pode conduzir ao "entrincheiramento” dos administradores em seus cargos, em oposição a potencial substituição a que estariam sujeitos em caso de tomada de controle. Há inúmeros estudos neste sentido, como, por exemplo, GOLDMAN, Eitan; SEVILIR, Merih. Large Shareholders and the Value of Takeover Defenses. 28.08.2008. Disponível em SSRN:

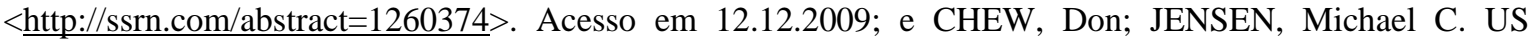
Corporate Governance: Lessons from the 1980's. In: JENSEN, Michael C. A Theory of the firm: governance, residual claims and organizational forms. Massachusetts: Harvard University Press, dez. 2000. Disponível em SSRN: <http://ssrn.com/abstract=146150>. Acesso em 12.12.2009. Análises foram feitas sobre as consequências do "entrincheiramento" dos administradores em seus cargos e o efeito perverso criado por esta disfunção no uso de medidas defensivas, conforme, por exemplo, BEBCHUK, Lucian A.; COHEN, Alma. The Costs of Entrenched Boards. Journal of Financial Economics. v. 78, 2005; Harvard Law and Economics Discussion Paper, n. 478, pp. 409-443. Disponível em SSRN: <http://ssrn.com/abstract=556987>. Acesso em 12.12.2009. Há estudos que equilibram a ideia de que as medidas defensivas conduzem ao "entrincheiramento" da administração. Com base em evidências empíricas, há quem sustente que tal fenômeno não é consequência direta da adoção de proteções contra a tomada de controle, como, por exemplo, JAGANNATHAN, Murali; PRITCHARD, Adam C. Does Delaware Entrench Management?. University of Michigan Law \& Economics, Olin Working Paper, n. 08-024, 08.12.2008. Disponível em SSRN: <http://ssrn.com/abstract=1313274> . Acesso em 12.12.2009; e CREMERS, Martijn; NAIR, Vinay B.; PEYER, Urs C. Takeover Defenses and Competition. Yale ICF Working Paper, n. 07-02; 2nd Annual Conference on Empirical Legal Studies Paper, abr. 2007. Disponível em SSRN: $<$ http://ssrn.com/abstract=984064>. Acesso em 12.12.2009.

${ }^{228}$ CORDEIRO, António Manuel da Rocha e Menezes. Da Tomada de Sociedades (Takeover): Efectivação, Valoração e Técnicas de Defesa. ROA. Lisboa, n. 54, pp. 761-777, 1994, p.775.
} 
sob esta perspectiva, como mecanismo contrário à evolução das práticas de gestão e administração de companhias dotadas de dispersão acionária.

Estudos de direito societário comparado revelam a existência de dois modelos básicos a serem utilizados na proteção contra medidas defensivas em companhias que possuem dispersão acionária. A distinção essencial consiste no critério de alocação do poder-dever decisório entre os acionistas da companhia-alvo e os órgãos de administração desta última, quanto à utilização de defesas diante de potenciais tomadas de controle ${ }^{229}$.

O primeiro modelo aloca o poder-dever decisório integralmente aos acionistas, mantendo os membros da administração completamente afastados da decisão. No segundo modelo, atribui-se à administração da companhia-alvo o poder-dever de decidir com relação à oferta realizada, conjuntamente com os acionistas da companhia-alvo.

O contraste entre a utilização desses dois modelos é evidenciado na comparação feita entre a experiência dos EUA e da Inglaterra, dois países em que há inúmeras companhias abertas com dispersão acionária ${ }^{230}$.

Em essência, a oferta pública de aquisição de ações consiste em proposta realizada pelo ofertante à pluralidade dos acionistas da companhia-alvo que possuam ações admitidas à negociação no mercado de capitais. Por esta razão, espera-se que, naturalmente, a decisão quanto à aceitação e/ou à rejeição da oferta pública seja tomada exclusivamente por tais acionistas.

Entretanto, há situações em que a companhia-alvo está protegida por medidas defensivas contra tomadas de controle hostis, atribuindo à administração poderes para de facto permitir ou impedir; ou recomendar ou não recomendar; que os acionistas da

\footnotetext{
${ }^{229}$ Paul Davies e Klaus Hopt sustentam que o aspecto crucial da distinção entre EUA e Inglaterra, nesta matéria, está na alocação do poder-dever de decidir quanto à aceitação de tais ofertas públicas de aquisição de controle, mais precisamente no que se refere à atribuição de tal poder-dever aos acionistas ou ao conselho de administração da companhia-alvo. (DAVIES, Paul; HOPT, Klaus J. Control Transactions. In: KRAAKMAN, Reinier et al. The Anatomy of Corporate Law: A Comparative and Functional Approach. Oxford: Oxford University Press, 2004, p. 163).

${ }^{230}$ Nas companhias em que há concentração de participação acionária em certos acionistas, o conselho de administração possuirá menor independência para a realização de manobras contra tentativas de tomada de controle, de modo que o problema de agência dominante nestes casos será entre, de um lado, os acionistas controladores e o potencial adquirente do controle e, de outro lado, acionistas minoritários da companhiaalvo.
} 
companhia-alvo aceitem ou rejeitem a oferta pública. Isto é, a administração da companhia-alvo exercerá um exame preliminar da oferta pública com poderes de impedir que os acionistas da companhia-alvo tenham ingerência quanto a sua aceitação.

Como consequência da existência das medidas defensivas que concedem ingerência à administração da companhia-alvo diante de ofertas públicas de aquisição de controle, a administração tende a influenciar os acionistas em sua decisão final quanto à aceitação ou rejeição da oferta pública. Uma postura resistente por parte da administração da companhia-alvo pode reduzir as chances de a oferta pública ser aceita pelos acionistas.

É importante esclarecer que, mesmo nos sistemas em que prevalece o modelo de atribuição aos acionistas do poder-dever de decidir quanto à oferta pública, não se espera que a administração da companhia-alvo adote postura totalmente passiva em relação à oferta ${ }^{231}$.

Nesse caso, o que é vedado é a administração agir unilateralmente para impedir que o ofertante tenha êxito na oferta pública. O propósito não é proibir a adoção, pela administração, de práticas que tenham o efeito, ainda que indireto ou reflexo, de frustrar a oferta pública realizada, mas sim de atribuir aos acionistas o poder-dever de decidir se tais medidas de defesa deverão ou não ser adotadas.

Em relação ao modelo que atribui o poder-dever de decidir sobre a oferta pública à administração da companhia-alvo, o sucesso da tentativa de tomada de controle estará diretamente associado à aprovação da operação pela administração. Reconhece-se, portanto, grande importância aos administradores no exame das propostas para mudança de controle.

A tomada de decisão em relação à oferta pública combinará a aprovação pela administração da companhia-alvo com a aceitação da oferta manifestada, posteriormente, pelos acionistas desta última, cujas ações estão dispersas no mercado.

\footnotetext{
${ }^{231}$ O Reino Unido é exemplo disto. Paul Davies e Klaus Hopt ensinam que, neste país, “incumbent management remains free to persuade shareholders to exercise their right of choice in a particular way and, indeed, is normally required by the takeover rules to provide the shareholders with an opinion on the offer" (DAVIES, Paul; HOPT, Klaus J. Control Transactions. In: KRAAKMAN, Reinier et al. The Anatomy of Corporate Law: A Comparative and Functional Approach. Oxford: Oxford University Press, 2004, p. 165).
} 
As decisões por parte dos acionistas, tanto para aceitar a oferta pública e, consequentemente, alienar suas respectivas ações, quanto para rejeitar a oferta pública e, assim, conservar a propriedade de suas respectivas ações, são normalmente tomadas individualmente, ao invés de serem decisão conjunta, tomada em Assembleia Geral.

Já que a aprovação societária pelos órgãos de administração assume especial importância neste segundo modelo, as estratégias de tomada de controle nas companhiasalvo que adotem tal método de distribuição do poder-dever de decidir quanto à oferta pública tendem a buscar a persuasão e convencimento dos membros dos órgãos de administração.

Ao longo deste trabalho serão examinadas inúmeras medidas defensivas contra tomadas de controle hostis. As regras e os princípios específicos dos diferentes sistemas jurídicos devem ser levados em consideração na análise da admissibilidade de cada medida defensiva.

Há elementos comuns que, desde logo, podem ser encarados como zona de convergência nos ordenamentos jurídicos em relação às medidas defensivas. Dentre estes, reconhece-se que as defesas não podem representar impedimento absoluto à tomada do controle de companhia com dispersão acionária. A defesa deve consistir em obstáculo proporcional ao ataque contra o qual será utilizada ${ }^{232}$.

A medida defensiva deve funcionar como elemento capaz de estruturar a proteção contra a tomada de controle, mas não deve impedi-la totalmente, passando a representar uma restrição completa e intransponível ao movimento de transferência do controle $^{233}$.

\footnotetext{
${ }^{232}$ A medida defensiva adotada deve ser um obstáculo razoável em oposição à tentativa de tomada de controle. Este elemento de equilíbrio é fundamental na exoneração de responsabilidade dos administradores da companhia-alvo, no exercício de esforços de resistência ao takeover (ALLEN, William T.; KRAAKMAN, Reinier. Commentaries and Cases on the Law of Business Organization. Nova York: Aspen Publishers, 2003, p. 502).

${ }^{233}$ Refira-se às conclusões do caso Moran v. Household International, Inc. (500 A.2.d 1346, Delaware, 1985, Rel. John J. McNeilly), examinado em maiores detalhes no item 6.1, no sentido de que as medidas defensivas não podem representar óbice absoluto e inescusável à tomada de controle, mas devem funcionar como um método capaz de estruturar a defesa contra a tomada de controle hostil.
} 
Visando ao apuro técnico-conceitual do entendimento das medidas defensivas, propomos a catalogação das mesmas com base em dois critérios.

Pelo primeiro critério, pertinente ao momento em que são estabelecidas ou praticadas, as medidas defensivas podem ser divididas entre preventivas e posteriores.

Pelo segundo critério, pertinente à natureza jurídica dos instrumentos utilizados para o estabelecimento ou prática das medidas defensivas, as mesmas podem ser classificadas entre estatutárias, contratuais e institucionais.

\subsubsection{Preventivas E Posteriores}

Com base no momento em que são estabelecidas ou praticadas, as medidas defensivas podem ser classificadas como preventivas ou posteriores ${ }^{234}$.

Esta distinção tem grande importância nas discussões sobre a violação de deveres da administração e eventual aplicação de responsabilidade aos administradores, em decorrência da adoção de medidas defensivas diante de oferta hostil.

Em países que adotam regras limitando a atuação da administração após o lançamento da oferta pública, o reconhecimento da separação das medidas defensivas entre

${ }^{234}$ Há proposta doutrinária para esta divisão no exterior. A este respeito, referir-se a CLARK, Robert Charles. Corporate Law. Boston / Toronto: Little, Brown and Company, 1986, p. 571. Na mesma linha, LEITÃO, Luís Manuel Teles de Menezes. As medidas defensivas contra uma oferta pública de aquisição hostil. O Direito. Ano 138, t. III, Coimbra: Almedina, 2006, p. 461; e CORDEIRO, António Manuel da Rocha e Menezes. Da Tomada de Sociedades (Takeover): Efectivação, Valoração e Técnicas de Defesa. ROA. Lisboa, n. 54, pp. 761-777, 1994, p. 772. 
preventivas e posteriores é fundamental para dimensionar as proteções que vigorarão durante o período de aceitação de tais medidas ${ }^{235}$.

A defesa bem estabelecida contra a tomada de controle parece ser a combinação de medidas defensivas preventivas com medidas defensivas posteriores.

\subsubsection{Medidas Defensivas PreVentivas}

As medidas defensivas preventivas ${ }^{236}$ são aquelas tomadas anteriormente à oferta hostil de aquisição de controle, como forma de evitar o takeover. São precauções à tentativa de tomada de controle, erigidas na lógica do provérbio de que “é melhor prevenir do que remediar”,237.

Por tratar-se de atos anteriores à ação de tomada de controle hostil, as espécies de medidas defensivas que se inserem nesta categoria são usualmente menos tendentes a implicar responsabilidades aos administradores na adoção de proteções contra a tomada de controle.

As medidas defensivas preventivas têm por objetivo tornar a companhia pouco penetrável a novas maiorias de acionistas, mediante articulações internas ${ }^{238}$. As companhias abertas, especialmente aquelas em que há dispersão acionária e,

\footnotetext{
${ }^{235}$ Dentre as recomendações de neutralidade à administração após o lançamento de uma oferta pública, contidas na Diretiva $n^{\circ}$ 2004/25/CE, o artigo 9", item (2), prevê que "[...] o órgão de administração da sociedade visada é obrigado a obter a autorização prévia da assembleia geral de acionistas para o efeito antes de empreender qualquer ação suscetível de conduzir à frustração da oferta, excetuando a procura de outras ofertas [...]”. Este é um dos casos em que é fundamental a distinção entre medidas defensivas preventivas e posteriores.

${ }^{236}$ É comum encontrar referência no direito português às medidas defensivas preventivas como sendo medidas organizatórias. Portanto, no estudo comparado entre Brasil e Portugal sobre este tema, as medidas defensivas preventivas e medidas defensivas organizatórias serão consideradas como sinônimos.

${ }^{237}$ Sob a mesma lógica, aplica-se também a ideia do provébio romano: "Prius antidotum quam venenum" (o antídoto antes do veneno). Além disso, considerando que a adoção de medidas defensivas é usualmente aplciável em contexto de enfrentamento entre ofertante e ofertado, remete-se, aqui, ao provérbio de Sun Tzu, estrategista militar chinês, segundo o qual: "Evitar guerras é muito mais gratificante do que vencer mil batalhas".

${ }^{238}$ CORDEIRO, António Manuel da Rocha e Menezes. Da Tomada de Sociedades (Takeover): Efectivação, Valoração e Técnicas de Defesa. ROA. Lisboa, n. 54, pp. 761-777, 1994, p. 773.
} 
consequentemente, maior exposição às tomadas de controle, adotam medidas de defesa como precaução para evitar que ocorram tentativas de takeover.

Além de dificultarem a tomada de controle, as medidas defensivas preventivas podem funcionar como instrumento pré-existente, concedendo tempo e mecanismos de proteção aos órgãos de administração e/ou aos acionistas da companhia-alvo, caso ocorra alguma indesejada tentativa de tomada de controle da companhia. Tais instrumentos podem tornar mais lento o processo de tomada de controle, permitindo que outras proteções e/ou estratégias de defesa sejam adotadas.

\subsubsection{Medidas Defensivas Posteriores}

As medidas defensivas posteriores são aquelas adotadas depois ter sido iniciada a oferta hostil para aquisição de controle. Trata-se de medidas defensivas adotadas ad hoc, quando já há uma tentativa de tomada de controle em andamento.

O limite temporal que se estabelece para distinguir a adoção de medidas defensivas como sendo posteriores é a publicação do anúncio da oferta pública de aquisição de controle e/ou de qualquer outro comunicado oficial ao mercado, por parte da companhia ofertante. Ou seja, enquanto o anúncio da oferta pública ou qualquer outro comunicado oficial ao mercado não houver sido realizado e, consequentemente, a tentativa de tomada de controle por meio de oferta pública não tenha se tornado de conhecimento público, a medida defensiva que vier a ser adotada poderá ser enquadrada como preventiva.

A questão principal nesta distinção sobre o momento em que é adotada a medida defensiva refere-se aos parâmetros de atuação e, talvez, responsabilização dos administradores da companhia-alvo. 
Tão logo a tentativa de tomada de controle torne-se conhecida, qualquer medida a ser adotada pela administração da companhia-alvo, em defesa contra mudanças de controle, estará sujeita a análise de admissibilidade muito mais rigorosa ${ }^{239}$.

As medidas defensivas posteriores são o reconhecimento de que, nem sempre, as medidas defensivas preventivas são suficientes para, por si só, assegurar a proteção de companhias com dispersão contra tentativas de tomada de controle hostil.

As defesas posteriores podem servir como mecanismos utilizados pela companhia-alvo para reforçar o seu arsenal defensivo diante de uma tentativa de tomada de controle.

\subsubsection{ESTATUTÁRIAS, CONTRATUAIS E INSTITUCIONAIS}

Com base no critério da natureza jurídica dos instrumentos utilizados para o estabelecimento ou prática das medidas defensivas, as mesmas podem ser classificadas como estatutárias, contratuais ou institucionais.

A classificação das medidas defensivas dentro destas categorias propostas é fundamental à análise da validade de adoção de tais mecanismos, principalmente por conta da importação que vem sendo feita de defesas típicas de sistemas jurídicos estrangeiros, sem levar em conta as características próprias de nosso ordenamento e sem a devida cautela quanto à compatibilidade destes instrumentos no Brasil.

\footnotetext{
${ }^{239}$ Frank Easterbrook e Daniel Fischel noticiam que o aumento do rigor na admissibilidade de adoção da medida defensiva também ocorre nos EUA, esclarecendo que "once a bid is on the table, Delaware requires the target's managers to take additional care to demonstrate that their acts may well benefit the firm" (EASTERBROOK, Frank H.; FISCHEL, Daniel R. The Economic Structure of Corporate Law. Paperback Edition, Massachusetts: Harvard University Press, 1996, p.164). Na Europa, este rigor está expresso na Diretiva n ${ }^{\circ}$ 2004/25/CE.
} 


\subsubsection{MEDIDAS DEFENSIVAS ESTATUTÁRIAS}

As medidas defensivas podem ser estabelecidas por disposições estatutárias, hipótese em que o estatuto social da companhia-alvo contemplará disposições destinadas a dificultar que o adquirente de participação acionária relevante assuma o controle da companhia-alvo.

No Brasil, as cláusulas de proteção à dispersão acionária, que vêm sendo equivocadamente chamadas de poison pills e sobre as quais trataremos no item 6.1, são o principal exemplo de medidas defensivas estatutárias. Entretanto, há também outras medidas defensivas estatutárias adotadas por companhias abertas brasileiras, como, por exemplo, a limitação ao número de $\operatorname{votos}^{240}$ de cada acionista, independentemente da quantidade de ações com direito de voto detida por este último, conforme prevê o artigo 110, $\S 1^{\circ}$, da Lei $n^{\circ} 6.404 / 76$.

Tal medida defensiva desestimula que qualquer acionista detenha ações votantes além do limite de votos autorizado pelo estatuto social, pois, independentemente do número de ações votantes que possuir, o acionista somente poderá exercer direito de voto até o limite previsto no estatuto social.

\subsubsection{Medidas Defensivas Contratuais}

\footnotetext{
${ }^{240}$ Na experiência internacional, a medida defensiva estatutária da limitação ao direito de voto pode assumir formas variadas. Luís Menezes Leitão sintetiza que estas podem ser: “(a) limitação ao número total de votos, que cada accionista pode possuir, independentemente da sua participação no capital; (b) cláusula de interesse, que determina que os accionistas que acordem na coordenação dos seus votos são vistos como um único; (c) suspensão temporária do direito de voto, no âmbito da qual se determinaria, por exemplo, a suspensão do direito de voto após a aquisição de acções entre um a seis meses para permitir à administração reagir; e (d) diferentes classes de votos em relação a diferentes categorias de acções, levando a que as acções com mais votos sejam detidas por uma entidade com o encargo de as conservar (normalmente, uma fundação ou um trust), enquanto as outras são livremente transaccionadas” (LEITÃO, Luís Manuel Teles de Menezes. As medidas defensivas contra uma oferta pública de aquisição hostil. O Direito. Ano 138, t. III, Coimbra: Almedina, 2006, pp. 457-475).
} 
As medidas defensivas contratuais são aquelas estabelecidas por meio de contrato, contendo disposições destinadas a proteger a companhia-alvo contra uma tentativa de tomada de controle.

A defesa se dá por meio da redução da atratividade da companhia-alvo, seja pela imposição de barreiras concorrenciais, seja pela estabilização da estrutura de poder de controle, com a coordenação de acionistas dispersos no mercado. Enfim, há uma infinidade de métodos defensivos que se auxiliam de disposições contratuais para serem adotados.

A opção jóias da coroa (crown jewel option) pode ser, exemplificativamente, citada como medida defensiva contratual, consistente na outorga pela companhia-alvo, a terceiros e/ou determinados acionistas e/ou administradores, de opção de comprar determinados bens e ativos da companhia-alvo, com previsão de que tal opção poderá ser exercida caso o controle desta última seja transferido.

À luz das técnicas de fortalecimento do poder de controle, pode-se pensar em convenções de voto como medidas defensivas contratuais. Em linha com o exposto no item 3.2.5, tais convenções de voto podem compreender acordos de acionistas, contratos de penhor de ações, usufruto de ações e alienação fiduciária de ações.

As convenções de voto, consideradas como medidas defensivas da espécie fortalecimento da esfera de controle, tanto podem ser preventivas quanto posteriores. Em relação às primeiras, cite-se, exemplificativamente, a existência de contrato com regras de convenção de voto, cuja eficácia está suspensivamente condicionada à ocorrência de operação tendente a transferir o controle da companhia-alvo. Em relação às segundas, embora de difícil realização, pela dificuldade de coordenar acionistas dispersos no mercado, pode-se conceber a celebração de eventual acordo de acionista, contratos de penhor de ações, usufruto de ações e alienação fiduciária de ações celebrado tão logo lançada a oferta pública.

Os empréstimos de ações que, eventualmente, sejam realizados para que determinado acionista detenha consigo quantidade de ações capaz de resistir à tentativa de tomada de controle também constituem medida defensiva contratual. 


\subsubsection{MEDIDAS DEFENSIVAS INSTITUCIONAIS}

Seguindo a proposta doutrinária de Fábio Konder Comparato ${ }^{241}$, as medidas defensivas institucionais consistem na criação de organismos, dotados ou não de personalidade jurídica, como defesa diante de tentativa de tomada de controle.

Sendo assim, a espécie de medida defensiva referida como fortalecimento da esfera de controle pode, em determinadas situações, representar uma medida defensiva institucional. Tal defesa consiste na congregação de acionistas integrantes da dispersão acionária para formarem organismos como, por exemplo, sociedades holdings, fundos de investimento, trusts, condomínios, consórcios de sociedades, dentre outros. A defesa, por tal método, pressupõe a conferência das ações de emissão da companhia-alvo detidas pelos acionistas, em ambiente de dispersão acionária, ao capital social e/ou ao patrimônio de tais organismos, conforme a natureza jurídica e características próprias de cada um destes.

As medidas defensivas institucionais devem ser sempre entendidas como posteriores, pois a aplicação das mesmas só é coerente como defesa a uma tentativa de tomada de controle que efetivamente vier ocorrer. Para fins de raciocínio, caso tais organismos de fortalecimento de controle existissem previamente ao lançamento de uma oferta pública, a mesma sequer seria lançada contra a companhia, pois esta não estaria organizada com dispersão acionária, que é premissa para a tentativa de tomada de controle.

A congregação da dispersão acionária em organismos tem o efeito de concentrar o poder de controle, consolidando estrutura de controle majoritário conjunto. Portanto, examinando a questão com rigor técnico-conceitual, a medida defensiva institucional jamais poderia ser preventiva.

\footnotetext{
241 Abordando as técnicas de organização do controle interno, Fábio Konder Comparato refere-se às institucionais como “aquelas técnicas de organização do controle interno que consistem na criação de um organismo, personalizado ou não, com o objetivo de consolidar a titularidade do poder soberano na sociedade e disciplinar-lhe o exercício”. Em seguida, propõe que as principais técnicas institucionais seriam a comunhão acionária, o voting trust e a sociedade holding (COMPARATO, Fábio Konder; SALOMÃO FILHO, Calixto. O Poder de Controle na Sociedade Anônima. 4. ed. Rio de Janeiro: Forense, 2005, p. 145).
} 
No compasso dessa reflexão, em nosso entendimento, os instrumentos jurídicos tendentes a funcionar como defesas institucionais não são propriamente defesas contra a tomada de controle, mas sim o abandono da estrutura de organização do capital social sob a forma da dispersão acionária, com a consequente migração para contexto de concentração acionária. Porém, diante dos efeitos que a adoção de tais instrumentos pode gerar, defendendo efetivamente a companhia de uma tentativa de tomada de controle, os mesmos serão abordados como medidas defensivas.

Contudo, deve-se ponderar pela difícil concretização na utilização da defesa institucional, pois esta requererá a coordenação de acionistas detentores de ações em quantidade suficiente para estruturar e concentrar o capital votante da companhia, formando algum organismo institucional.

\section{2}

Parâmetros de análise da Validade das Medidas Defensivas no BRASIL

As medidas defensivas de inspiração no direito estrangeiro, que vêm sendo adotadas no Brasil, devem passar por um crivo cuidadoso no que diz respeito a sua validade, de modo a aferir-se a possibilidade de seu emprego no país. Segundo entendemos, este exame de validade deve ser realizado tanto na dimensão do direito civil quanto na do direito empresarial.

Situando-nos na esfera do direito civil, atenção especial deve ser dedicada às medidas defensivas contratuais, que se revestem das características dos negócios jurídicos $^{242}$.

\footnotetext{
${ }^{242}$ Como ensina Antônio Junqueira de Azevedo, “in concreto, negócio jurídico é todo fato jurídico consistente em declaração de vontade, a que o ordenamento jurídico atribui os efeitos designados como queridos, respeitados os pressupostos de existência, validade e eficácia impostos pela norma jurídica que sobre ele incide" (AZEVEDO, Antônio Junqueira de. Negócio jurídico: existência, validade e eficácia. São Paulo: Saraiva, 2002, p.16).
} 
A mais autorizada doutrina civilística define três planos distintos para a análise do negócio jurídico, a saber: plano da existência, da validade e da eficácia ${ }^{243}$. Uma vez verificada a adequação de determinado negócio sob esta perspectiva tridimensional, podese, enfim, determinar se ele se encontra ou não em plenas condições de realização.

Como veremos nas linhas a seguir, não basta ao negócio existir; ele deve ser válido $^{244}$. E aqui reside, a nosso ver, o ponto mais delicado da análise das medidas defensivas de inspiração no direito estrangeiro, justamente em virtude da dificuldade de precisarem-se parâmetros claros. Mas não é só. Deve o negócio, além de valer, ser plenamente apto a produzir efeitos.

No plano inicial da existência, o negócio jurídico, como expressão da declaração de vontade produtora de efeitos jurídicos, deve conter seus elementos essenciais, que são aqueles indispensáveis à sua existência ${ }^{245}$. Ganham também relevo os chamados elementos acidentais, dos quais podem se valer as partes do negócio, no exercício de sua autonomia privada, para modificar a eficácia do ato, adaptando-a a circunstâncias futuras. Embora não sejam da essência do negócio jurídico, uma vez a ele apostos, os elementos acidentais, que se traduzem em cláusulas acessórias (como a condição, o termo e o encargo), passam a integrá-lo.

As medidas defensivas só podem ser regularmente admitidas no ordenamento jurídico brasileiro e produzirem plenos efeitos, caso sejam válidas. Em outras palavras, devem elas observar os requisitos básicos de validade, definidos no artigo 104 do Código

\footnotetext{
${ }^{243}$ AZEVEDO, Antônio Junqueira de. Negócio jurídico: existência, validade e eficácia. São Paulo: Saraiva, 2002, p. 24.

${ }^{244}$ Nas palavras do ilustre Professor Junqueira de Azevedo: “entre existir e produzir efeitos, interpõe-se a questão de valer” (Ibid., p. 41).

${ }^{245}$ Valendo-nos da divisão tradicionalmente utilizada pela doutrina civilista, os elementos do negócio jurídico podem ser essenciais, naturais e acidentais. Os "elementos essenciais são aqueles sem os quais o negócio jurídico não existe” (ALVES, José Carlos Moreira. Direito Romano. v.1, 3. ed. Rio de Janeiro: Forense, 1971, p. 172), e podem ser sintetizados, grosso modo, na tríade vontade, objeto e forma. Os elementos naturais, por sua vez, "são as conseqüências que decorrem do próprio ato, sem que haja necessidade de expressa menção", ao passo que os elementos acidentais "são estipulações que facultativamente se adicionam ao ato para modificar-lhe uma ou algumas de suas conseqüências naturais, como a condição, o termo e o modo, ou encargo" (MONTEIRO, Washington de Barros. Curso de Direito Civil: parte geral. v. 1, 41. ed. São Paulo: Saraiva, 2007, p. 184). Os elementos acidentais (i.e., termo, condição ou encargo) é que determinarão, casuisticamente, a produção de efeitos dos respectivos negócios jurídicos e os métodos empregados no exterior podem naturalmente se adequar ao nosso sistema jurídico, desde que submetidos a simples adequações sistêmicas.
} 
Civil, assim sintetizados: (i) agente capaz, (ii) objeto lícito, possível, determinado ou determinável; e (iii) forma prescrita ou não defesa em lei.

Os parâmetros de validade não se esgotam no referido dispositivo legal ${ }^{246}$. É preciso ter em mente, ainda, os chamados novos princípios contratuais, em especial a função social do contrato e a boa-fé objetiva, além das chamadas normas de ordem pública.

Convém, a este propósito, referir-se ao parágrafo único do artigo 2.035 do Código Civil, segundo o qual não prevalecerá convenção que contrarie preceitos de ordem pública, "tais como os estabelecidos por este Código para assegurar a função social da propriedade e dos contratos”. Nesta linha, as medidas defensivas constituídas como negócios jurídicos sujeitam-se, no que respeita a sua validade, às cláusulas gerais do Código Civil, especialmente a função social do contrato e a boa-fé objetiva ${ }^{247}$, que

\footnotetext{
${ }^{246}$ Veja-se, a respeito, as precisas considerações de Antônio Junqueira de Azevedo: “[A] declaração de vontade, tomada primeiramente como um todo, deverá ser: a) resultante de um processo volitivo; b) querida com plena consciência da realidade; c) escolhida com liberdade; d) deliberada sem má fé [...]. O objeto deverá ser lícito, possível e determinado ou determinável; e a forma, ou será livre, porque a lei nenhum requisito nela exige, ou deverá ser conforme a prescrição legal. Quanto às circunstâncias negociais, não têm requisitos exclusivamente seus, já que elas são o elemento caracterizador da essência do próprio negócio, são aquele quid que qualifica uma manifestação transformando-a em declaração. Quanto aos elementos gerais extrínsecos, temos que: a) agente deverá ser capaz e, em geral, legitimado para o negócio; b) o tempo, se o ordenamento jurídico impuser que o negócio se faça em um determinado momento [...]; e c) o lugar, se, excepcionalmente tiver algum requisito, há de ser o lugar apropriado” (AZEVEDO, Antônio Junqueira de. Negócio jurídico: existência, validade e eficácia. São Paulo: Saraiva, 2002, pp. 42-43). Em suas considerações, o ilustre autor prossegue ainda no exame dos elementos categoriais inderrogáveis (i.e., elementos essenciais do negócio jurídico), com breve abordagem de requisitos próprios de determinados tipos de negócios jurídicos, os quais devem ser igual e casuisticamente considerados no exame da validade de cada uma das medidas defensivas conforme a natureza jurídica do instituto por meio das quais estas se exteriorizem, como por exemplo: compra e venda, doação e outros.

${ }^{247}$ A teoria do contrato vem sendo marcada pelo reconhecimento de novos princípios, dos quais são grandes expoentes a boa-fé objetiva e a função social do contrato. Mesmo os princípios clássicos, como o da relatividade dos contratos, vêm assumindo nova roupagem. Com a positivação do princípio da boa-fé objetiva no Código Civil de 2002, passou-se a conferir-lhe o desempenho de três funções distintas: (i) a função interpretativa (art. 113); (ii) a função de limitação do exercício abusivo do direito (art. 187); e (iii) a função de imposição de deveres laterais ou acessórios de conduta a serem observados pelas partes, dentre os quais se destacam os deveres de cooperação, cuidado, informação e sigilo nas relações contratuais. A este respeito, confira-se, em especial, MARTINS-COSTA, Judith. A boa-fé no direito privado. São Paulo: RT, 1999; e CORDEIRO, António Manuel da Rocha e Menezes. Da boa-fé no direito civil. v. 1, Coimbra: Almedina, 1984. Aliás, a boa-fé objetiva e a função social do contrato são princípios intimamente relacionados, conforme se pode perceber do ilustrativo excerto doutrinário: “A boa-fé objetiva, cláusula geral prevista no CC 422, decorre da função social do contrato, de modo que tudo o que se disser sobre a boa-fé objetiva poderá ser considerado como integrante, também, da cláusula geral da função social do contrato" (NERY JÚNIOR, Nelson; NERY, Rosa Maria de Andrade. Código Civil anotado e legislação extravagante. 2. ed. São Paulo: RT, 2003, p. 336). Quanto à função social do contrato, é de se dizer que a "liberdade de contratar está limitada pela supremacia da ordem pública, que veda convenções que lhe sejam contrárias e aos bons costumes, de forma que a vontade dos contraentes está subordinada ao interesse coletivo. [...] Como a lei não define a locução 'função social do contrato', poderá ela ser interpretada de formas diversas,
} 
acompanham a relação contratual desde o seu início, permanecem durante toda a sua vida e subsistem mesmo após se ter extinguido ${ }^{248}$.

Como se vê, o legislador atribuiu aos princípios da função social do contrato e da boa-fé objetiva a característica de normas de ordem pública, inderrogáveis pela vontade das partes, e que devem ser respeitadas a fim de que se repute válido o negócio jurídico ${ }^{249}$. É importante, no entanto, chamar a atenção ao fato de que tais cláusulas gerais sofrem certos temperamentos no campo do direito empresarial e, especialmente, do direito societário, de feição marcadamente dinâmica e paritária ${ }^{250}$.

conduzindo à declaração de nulidade de cláusulas ou até mesmo de toda a avença. Por isso, procuramos delinear alguns parâmetros a serem seguidos, pois com essa função social do contrato teremos o justo processo legal substantivo. A liberdade de contratar é reconhecida, mas seu exercício está condicionado à função social do contrato e implica valores de boa fé e probidade (CC, art. 422). Logo, a função social do contrato não elimina o princípio da autonomia contratual, mas atenua ou reduz seu alcance quando estiverem presentes interesses meta-individuais ou interesse individual relativo à dignidade da pessoa humana” (DINIZ, Maria Helena. Das disposições finais e transitórias. In: AZEVEDO, Antônio Junqueira de. Comentários ao Código Civil. v. 22. São Paulo: Saraiva, 2003, pp. 181-182).

${ }^{248}$ Avançando um pouco mais na análise, é válido também indagar se a boa-fé objetiva, como verdadeira norma de conduta, poderia constituir parâmetro de validade das medidas defensivas empregadas no país. Por exemplo, não restam dúvidas de que a violação de deveres impostos pelo princípio da boa-fé pode ensejar a obrigação de reparação civil a título de perdas e danos, na medida em que se está diante de um ato ilícito. O que se questiona é se a ofensa à boa-fé pode dar margem não propriamente à responsabilidade civil, mas à declaração de invalidade de um negócio jurídico. A questão não é, de todo, nova e já foi posta, em semelhantes termos, por RIBEIRO, Joaquim de Sousa. A boa-fé como norma de validade. In: __ . Direito dos contratos: estudos. Coimbra: Coimbra Editora, 2007, mas sua análise mais aprofundada escapa ao foco deste trabalho.

249 “A boa-fé objetiva impõe ao contratante um padrão de conduta, de modo que deve agir como um ser humano reto, vale dizer, com probidade, honestidade e lealdade. Assim, reputa-se celebrado o contrato com todos esses atributos que decorrem da boa-fé objetiva. Daí a razão pela qual o juiz ao julgar demanda na qual se discuta a relação contratual, deve dar por pressuposta a regra jurídica (lei, fonte de direito, regra jurígena criadora de direitos e obrigações) de agir com retidão, nos padrões do homem comum, atendidas as peculiaridades dos usos e costumes do lugar” (Ibid., pp. 338-339).

${ }^{250}$ Gustavo Tepedino e Anderson Schreiber anotam: "É evidente que a aplicação do princípio da boa-fé objetiva nas relações mercantis e societárias deve repercutir de modo diverso daquele que se tem vislumbrado no âmbito consumerista. O campo interempresarial não é apenas paritário, no sentido de que não há flagrante desequilíbrio entre as partes a ser corrigido pela atividade jurisdicional, mas se caracteriza, ainda, pela presença de pessoas jurídicas que, em situação de equilíbrio econômico e jurídico, negociam direitos e obrigações, de forma puramente patrimonial, e até matemática, de modo que à aquisição de cada direito corresponde um custo que, de uma forma ou de outra, acaba incorporada ao preço da operação. O ambiente comercial e societário, e, em particular, o ambiente interempresarial, são palco de interesses distintos daqueles que guiam as relações obrigacionais comuns, e se encontram ainda mais distantes dos valores existenciais que recomendam uma tutela protetiva. [...] Com efeito, a boa-fé objetiva não pode ser aplicada da mesma forma às relações de consumo e às relações mercantis ou societárias, pela simples razão de que os standards de comportamento são distintos. Assim, enquanto no exemplo da compra e venda de um automóvel exige-se que o vendedor forneça ao comprador toda informação relevante acerca do veículo e qualquer outro dado relacionado à função social e econômica do contrato, a aquisição de controle de uma determinada sociedade, por outro lado, envolve normalmente uma avaliação dos custos, riscos e passivos da sociedade (due diligence) pela própria empresa adquirente, o que, se não isenta o alienante do seu dever de informação, reduz evidentemente a sua intensidade" (TEPEDINO, Gustavo; SCHREIBER, Anderson. Os 
No Brasil, a existência das mencionadas cláusulas gerais deve-se, em especial, à tentativa, por parte do legislador, de reparar desequilíbrios e abusos que desvirtuam o exercício da autonomia da vontade e encontram-se presentes, sobretudo, em relações jurídicas desniveladas, como as de direito do consumidor, que, a rigor, não se aproximam das relações societárias. Embora a legislação societária, a teor do que dispõe o artigo 1.089 do Código Civil, se harmonize e, em casos omissos, até mesmo se complemente com as regras daquele diploma legal, não se deve engessar o direito societário com a aplicação de institutos típicos da esfera do direito civil sem que se proceda às necessárias moderações.

Pode-se dizer, grosso modo, que os requisitos ou pressupostos gerais de validade são a capacidade e a legitimidade das partes. A primeira traduz-se num modo de ser ou qualidade do sujeito em si, ao passo que a segunda constitui relação entre o sujeito e o conteúdo do ato.

As considerações aqui tecidas são relevantes pelas consequências de se considerar um negócio válido ou não. Está-se a falar, justamente, da nulidade e da anulabilidade, que podem ser enquadradas como espécie do gênero invalidade (por sua vez contida na ideia de ineficácia, em sentido amplo). A invalidade se caracteriza como a ineficácia decorrente de vícios ou irregularidades nos elementos essenciais (ou intrínsecos) do negócio.

Os efeitos de se reputar um negócio nulo ou anulável são distintos. O negócio eivado de nulidade não produz, desde o início, os efeitos a que tendia, diferentemente do que se passa com o negócio anulável, que produz os seus efeitos e é tratado como válido, até que seja anulado judicialmente. Vê-se, pois, que o regime da nulidade é mais severo que o da anulabilidade, o que se justifica pela prevalência do interesse público (questões de ordem pública), diferentemente da anulabilidade, que diz respeito a infrações de requisitos destinados à tutela de interesses predominantemente particulares.

efeitos da Constituição em relação à cláusula geral da boa-fé no Código de Defesa do Consumidor e no Código Civil. Revista da EMERJ. Rio de Janeiro: EMERJ, v. 6, n. 23, 2003, pp. 150-151). 
O artigo 166 do Código Civil reputa nulo ${ }^{251}$ o negócio jurídico quando:

celebrado por pessoa absolutamente incapaz; (ii) ilícito, impossível ou indeterminável o seu objeto; (iii) o motivo determinante, comum a ambas as partes, for ilícito; (iv) não revestir a forma prescrita em lei; (v) for preterida alguma solenidade que a lei considere essencial para a sua validade; (vi) tiver por objetivo fraudar lei imperativa; e (vii) a lei taxativamente o declarar nulo, ou proibir-lhe a prática, sem cominar sanção.

Quanto aos negócios jurídicos anuláveis, sem prejuízo de outros dispositivos que cominem esta consequência aos negócios jurídicos que não sobreviverem ao exame pelo plano da validade, o artigo 171 do Código Civil prevê como causas de anulabilidade: (i) a incapacidade relativa do agente; ou (ii) vício resultante de erro, dolo, coação, estado de perigo, lesão ou fraude contra credores.

Superados estes parâmetros de análise da validade das medidas defensivas, sob influência do direito civil, deve-se, em seguida, atentar para as balizas previstas no direito empresarial, mais especificamente no direito societário. Já se disse, a respeito dos princípios contratuais, que as peculiaridades típicas do terreno do direito societário impõem que se façam certas ponderações e temperamentos. Isto é ainda mais verdadeiro em matéria de nulidades, devendo-se privilegiar não apenas o interesse de terceiros de boafé, mas o próprio funcionamento regular da vida societária, de onde resulta a maior preocupação em garantir que os atos e negócios anuláveis produzam efeitos, até posterior declaração de sua anulabilidade ${ }^{252}$.

${ }^{251}$ O caput do artigo 167 do Código Civil também prevê que é nulo o negócio jurídico simulado, mas subsistirá o que se dissimulou, se válido for na substância e na forma.

${ }^{252}$ Embora tratando do regime das nulidades em matéria de deliberações assembleares, Erasmo Valladão Azevedo e Novaes França é preciso: "Se se fosse seguir a teoria das nulidades do direito comum, ter-se-ia que a assembléia geral irregularmente convocada ou instalada seria absolutamente nula, porque, entre outras coisas, o ato que viola a lei imperativa é nulo. No entanto, a lei diz que, nessa hipótese, ela é meramente anulável. [...] Se o sócio, apesar de a assembléia ter sido irregularmente convocada ou instalada, não quiser propor a ação anulatória, por que haveria o legislador de prescrever a nulidade absoluta do conclave? Nós já vimos que, da estabilidade da assembléia e suas deliberações, depende o bom funcionamento da empresa societária. [...] Há uma única exceção, no meu modo de ver, e também da maioria da doutrina: é a da ausência de convocação" (FRANÇA, Erasmo Valladão Azevedo e Novaes. Invalidade das deliberações sociais. Revista do Advogado. São Paulo: Associação dos Advogados de São Paulo, n. 57, jan. 2000, pp. 5253). A própria exiguidade dos prazos prescricionais no âmbito do direito societário (embora não tão exíguos como de outros ordenamentos jurídicos) é sintomática desse regime diferenciado das nulidades societárias. Ecoando as lições de Erasmo Valladão Azevedo e Novaes França, entendemos que os prazos prescricionais deveriam ser ainda mais exíguos na legislação societária brasileira (Idem. Invalidade das Deliberações de Assembléia das S.A. São Paulo: Malheiros Editores, 1999, p. 69, nota de rodapé n. 7; e Idem. Lineamentos da 
Deve ser observada a regra inscrita no $\S 1^{\circ}$ do artigo 109 da Lei $n^{\circ}$ 6.404/76, que estabelece a igualdade de direitos aos titulares de ações de mesma classe. O pressuposto que se tem é de que a igualdade de posição jurídica exige a igualdade de direitos, de modo que, dentro de uma mesma classe, não pode haver diferenças ou privilégios entre os acionistas, sob pena de violação ao princípio societário de igualdade de tratamento, insculpido no $\S 1^{\circ}$ do artigo 109 da Lei ${ }^{\circ}$ 6.404/76.

Portanto, nenhum mecanismo de proteção contra tomadas de controle, qualquer que seja a sua natureza, inclusive estatutária ou contratual, poderá tratar distintamente acionistas de mesma classe e espécie. A medida defensiva que assim dispuser será reputada inválida, por violação de norma societária imperativa e de ordem pública.

A igualdade de tratamento também encontra guarida nos dispositivos pertinentes ao direito de preferência na subscrição de ações, conforme previsto no artigo 171 da Lei $\mathrm{n}^{0}$ 6.404/76. O direito de preferência equilibra o direito dos acionistas da companhia para subscreverem ações e valores mobiliários conversíveis em ações, observadas as exceções legalmente estabelecidas. A exclusão do direito de preferência na subscrição de ações se dá exclusivamente no caso de venda de valores mobiliários em bolsa ou distribuição mediante oferta pública. Entretanto, de um lado, nas vendas em bolsa não será possível identificar o adquirente, o que impossibilitará a discriminação entre acionistas e, de outro lado, nas ofertas públicas a regulamentação exige tratamento equitativo aos destinatários da oferta, conforme previsto no artigo 21 da Instrução CVM nº. 400/03.

De igual maneira, as medidas defensivas deverão ser sempre adotadas dentro dos limites e orientadas pelo interesse social ${ }^{253}$, positivado no $\S 1^{\circ}$ do artigo 115 da Lei $\mathrm{n}^{\circ}$

Reforma do Direito Societário Italiano em Matéria de Invalidade das Deliberações Assembleares. In: Temas de Direito Societário, Falimentar e Teoria da Empresa. São Paulo: Malheiros Editores, 2009, p. 101, nota de rodapé n. 3).

${ }^{253}$ Erasmo Valladão Azevedo e Novaes França, examinando o conceito do interesse social à luz das teorias formuladas para o estudo de tal instituto de direito societário, afirmou que "as teorias elaboradas em torno do interesse social dividem-se em dois grandes grupos: as teorias institucionais e as contratualistas. Para as primeiras, o interesse social abrange também interesses diversos dos interesses dos acionistas; para as segundas, resume-se ele ao interesse coletivo destes” (FRANÇA, Erasmo Valladão Azevedo e Novaes. Conflito de interesses nas assembléias de S.A. São Paulo: Malheiros Editores, 1993. p. 22). 
6.404/76. Reporta-se, então, à conceituação de interesse social de Luiz Gastão Paes de Barros Leães:

[...] entendendo-se o interesse da companhia, não como o somatório dos interesses privados dos sócios, nem como um interesse autônomo desvinculado dos interesses dos acionistas da companhia, mas como o interesse comum dos sócios (qua socii e não enquanto indivíduos), norteado no sentido da realização do objeto social ${ }^{254}$.

Portanto, as medidas defensivas devem orientar-se pelo interesse social, sendo a satisfação deste o objetivo maior a ser alcançado nas companhias, de modo que a utilização de medidas defensivas deverá sempre procurar se harmonizar com esta orientação.

Feitas estas ponderações genéricas, esclareça-se que os parâmetros aqui expostos brevemente não são exaustivos, tanto na dimensão do direito civil quanto na do direito empresarial.

O exame de admissibilidade de cada uma das medidas defensivas deve ser realizado de forma profunda e casuística, respeitando-se as características e peculiaridades de cada espécie de medida defensiva, com as variações decorrentes da utilização concreta por companhias brasileiras, especialmente quando tais proteções tiverem sido meramente importadas do estrangeiro sem adequação ao nosso sistema.

O mero transplante de medidas defensivas de outros países para o Brasil, sem a devida adequação à nossa realidade, além de criar instrumentos de legalidade questionável,

\footnotetext{
${ }^{254}$ LEÃES, Luiz Gastão Paes de Barros. Conflito de interesses e vedação de voto nas assembléias das sociedades anônimas. RDM. São Paulo: Malheiros, n. 92, pp. 107-110, out./dez. 1993, p. 107. Ilustrando a conceituação do interesse comum dos sócios enquanto sócios, Erasmo Valladão Azevedo Novaes e França, com seu peculiar rigor técnico-conceitual, complementa que "os sócios, além dos seus interesses individuais, podem ter vários interesses comuns, não necessariamente ligados à sua posição de sócios. Numa sociedade familiar, por exemplo, os sócios podem ter interesses comuns enquanto membros de uma mesma família" (FRANÇA, Erasmo Valladão Azevedo e Novaes. Conflito de interesses nas assembléias de S.A. São Paulo: Malheiros Editores, 1993, p. 27). É com base nesta concepção que a doutrina acrescenta a ideia de que o interesse social é o interesse comum dos sócios enquanto sócios, e não enquanto indivíduos (uti socii e não uti individui). A este respeito, já tivemos a oportunidade de mencionar que "O interesse social concebido dessa maneira, não se identifica com outros interesses comuns dos sócios, nem representa um somatório dos interesses individuais dos acionistas, caracterizando-se, outrossim, como um interesse ex causa societatis, decorrente de seu status socii” (NASCIMENTO, João Pedro Barroso do. Conflito de interesses no exercício do direito de voto nas sociedades anônimas ( $1^{\text {a }}$ parte). RDB. São Paulo: RT, n. 24, pp. 140-156, abr./jun. 2004, especialmente nas pp. 153-154).
} 
poderá dar origem a mecanismos que não conseguirão desempenhar o papel de prevenção às tomadas de controle ao qual se destinam. 


\section{ESPÉCIES DE MEDIDAS DEFENSIVAS}

Há inúmeras medidas defensivas disponíveis para serem adotadas como formas de proteção contra tentativas de tomada de controle. A criatividade da comunidade jurídica e do empresariado em geral é capaz de conceber infinitas formas, sempre respeitando a legislação aplicável.

A experiência prática apropriou nomenclaturas curiosas para determinadas espécies de medidas defensivas ${ }^{255}$. Em sua maioria, tais nomenclaturas fazem referência ao ambiente de guerras e batalhas inerentes às disputas em tomadas de controle.

Entretanto, com o objetivo de examinar em maiores detalhes determinadas espécies de medidas defensivas existentes, na sequência, serão estudadas algumas das principais destas.

\subsection{Píllula de Veneno (POISON PILL)}

As pílulas de veneno, referidas como poison pills ${ }^{256 \_257}$, são provavelmente a forma mais famosa de defesa contra tomadas de controle hostis. Em alguns casos, esta

\footnotetext{
${ }^{255}$ É curiosa a ponderação de Modesto Carvalhosa quanto à nomenclatura utilizada para as espécies de medidas defensivas. "Nos Estados Unidos, as práticas selvagens de defesa, envolvendo o patrimônio da companhia visada, apresentam-se com jargões próprios de um ambiente de marginalidade" (CARVAlHOSA, Modesto. Comentários à Lei de Sociedades Anônimas. v. 4, t. II, 2. ed. rev. e atual. São Paulo: Saraiva, 2003, p. 266).

${ }^{256}$ A criação das poison pills é atribuída ao advogado norte-americano Martin Lipton, um dos sócios fundadores do escritório de advocacia Watchell, Lipton, Rosen \& Katz, durante a década de 1980, em meio às inúmeras tentativas de tomada de controle perpetradas nos EUA. O próprio Martin Lipton se intitula inventor de tal medida defensiva e aponta o renomado advogado norte-americano Joseph Flom, do escritório de advocacia Skadden, Arps, Slate, Meagher \& Flom como o seu principal adversário e responsável pela assessoria jurídica nos principais ataques para tomada de controle contra os quais a poison pill foi oposta em tal período. A este respeito, referir-se a LIPTON, Martin; ROWE, Paul K. Pills, Polls and Professors: A Reply to Professor Gilson. New York University Center for Law and Business Research Paper, n. 01-006, abr. 2001. Disponível em SSRN: <http://ssrn.com/abstract=268520>. Acesso em 12.12.2009.

${ }^{257}$ A nomenclatura "poison pill” ou "pílula de veneno" é atribuída em alusão às cápsulas de cianeto ou arsênico levadas por espiões, que as poderiam ingerir em caso de captura pelo inimigo. Entretanto, tal nomenclatura é criticada por Martin Lipton, reconhecido como o criador de tal medida defensiva, que
} 
espécie de medida defensiva é erroneamente classificada como se fosse o gênero em que se inserem todas as demais espécies de medidas de defesa. Ocorre que a poison pill é apenas mais uma das espécies do gênero das medidas defensivas.

As poison pills são reconhecidamente uma grande inovação no direito societário, que se mostrou bastante eficiente, apesar de controversa ${ }^{258}$, servindo para propiciar mecanismos de consolidação de estruturas de poder em companhias dotadas de dispersão acionária.

Os planos clássicos de poison pill consistem em planos de direitos atribuíveis aos acionistas, que estabelecem que a realização de oferta pública de aquisição de controle, tendo por objeto certa companhia-alvo e/ou a aquisição de participação acionária para além de certos limites de participação acionária na companhia-alvo, sem aprovação de seus órgãos de administração, atribui aos demais acionistas direitos de aquisição ou subscrição de ações, normalmente, a preços bastante inferiores aos praticados pelo mercado ${ }^{259}$.

Robert Clark doutrina que os planos de poison pill podem se apresentar em diferentes versões, sendo destacados os planos envolvendo direitos de conversão, resgate e subscrição $^{260}$.

Em sua forma original e mais simples, os planos de poison pill consistem em dividendo distribuído aos acionistas detentores de ações ordinárias de companhia suscetível à tomada de controle, mediante pagamento em ações preferenciais, sem direito de voto, de tal companhia. Tais ações preferenciais seriam conversíveis em ações ordinárias em caso de tentativa de tomada de controle, caracterizada pela aquisição de

esclarece que tal nomenclatura foi proposta por um banqueiro de investimentos que não tinha nenhuma relação com sua criação, mas quando consultado por um repórter do Wall Street Jounal a respeito de tal medida defensiva adotada, in casu, pela companhia Lenox, Inc., com a assessoria jurídica de Martin Lipton referiu-se coloquialmente a tal defesa como poison pill (conforme LIPTON, Martin; ROWE, Paul K. Pills, Polls and Professors: A Reply to Professor Gilson. New York University Center for Law and Business Research Paper, n. 01-006, abr. 2001. Disponível em SSRN: <http://ssrn.com/abstract=268520>. Acesso em 12.12.2009).

${ }^{258}$ ALLEN, William T.; KRAAKMAN, Reinier. Commentaries and Cases on the Law of Business Organization. Nova York: Aspen Publishers, 2003, pp. 506-507.

${ }^{259}$ A doutrina norte-americana é muito farta sobre o tema, e alguns autores lembram ainda que os planos de poison pill podem se dar com a emissão de quaisquer valores mobiliários e não apenas ações (BAUMAN, Jeffrey D.; WEISS, Elliot J.; PALMITER, Alan R. Corporations - Law and Policy - Materials and Problems. 5. ed. Saint Paul: Thomson - West Group, 2003, p. 1103).

${ }^{260}$ CLARK, Robert Charles. Corporate Law. Boston / Toronto: Little, Brown and Company, 1986, pp. 574575. 
ações em montante correspondente a certo limite de participação acionária previamente estabelecida.

A utilização dos planos de poison pill desenvolveu-se e continua em constante processo evolutivo. A atual versão mais popular dos planos de poison pill é conhecida, nos EUA, como Share Purchase Rights Plan - SRP ${ }^{261}$. Em tal modelo de poison pill, em vez de serem utilizados valores mobiliários conversíveis em ações votantes, as companhiasalvo distribuem, como dividendos aos seus acionistas, direitos que autorizam todos eles (à exceção daquele que eventualmente estiver tentando tomar o controle da companhia-alvo) a adquirirem ações de emissão desta última, em condições privilegiadas, durante um determinado período.

Os planos de poison pill, sob a forma de Shareholders Rights Plan - SRP, estabelecem que a realização de oferta pública de aquisição, tendo por objeto quantidade determinada de ações de emissão da companhia-alvo, capaz de promover a transferência do controle desta última, atribuirá: (i) à administração da companhia-alvo, a possibilidade de adotar programa de recompra de ações de sua própria emissão; ou (ii) aos acionistas da companhia-alvo, direitos de resgate de suas ações ou aquisição ou subscrição de ações, normalmente, a preços bastante inferiores àqueles praticados pelo mercado ${ }^{262}$.

Como regra geral, estes programas de poison pill estabelecem que a eficácia de tais direitos atribuídos aos acionistas está suspensivamente condicionada à ocorrência do evento que disparará o "gatilho", momento a partir do qual estará autorizado o exercício de tais direitos. Tipicamente, este evento que dispara o "gatilho" consiste no anúncio da oferta pública visando à aquisição de determinado percentual do capital social da companhiaalvo. Até que tal evento ocorra, há mecanismos no sentido de restringir que os direitos atribuídos aos acionistas sejam transferidos, com o objetivo de evitar que os mesmos sejam

\footnotetext{
${ }^{261}$ Plínio José Lopes Shimegatsu explica que "outra forma de poison pill é a chamada poison put. Neste mecanismo, a companhia que está sendo alvo de uma oferta de aquisição emite bonds contendo opções de venda exercíveis se e somente se uma oferta hostil ocorrer. Esse mecanismo permite que os portadores desses direitos, uma vez lançada uma oferta hostil, exerçam suas opções acarretando um aumento do desembolso financeiro para a aquisição da empresa” (SHIMEGATSU, Plínio José Lopes. Mecanismos de proteção e estratégias de defesa em tomadas hostis de controle. In: CASTRO, Rodrigo R. Monteiro; ARAGÃO, Leandro Santos de. Direito Societário: Desafios Atuais. São Paulo: Quartier Latin, 2009, p. 406).

${ }^{262}$ Cf. Nota 259.
} 
dissociados das ações que ensejaram a sua atribuição. Busca-se, assim, impedir que tais direitos de resgate, aquisição ou subscrição sejam negociados por seus titulares.

Nos EUA, o caso paradigmático sobre a admissibilidade dos planos de poison pill como defesa contra tomadas de controle é o Moran v. Household International, Inc. ${ }^{263}$ ${ }^{264}$. O caso teve grande repercussão, por ter sido a primeira ocasião em que os planos de poison pill, que haviam se tornado extremamente populares em companhias norteamericanas dotadas de dispersão acionária, seriam submetidos à discussão perante o Judiciário.

O Judiciário norte-americano, mais especificamente os tribunais do Estado de Delaware, reconheceu o plano de poison pill como instrumento legítimo de defesa, entendendo que a decisão dos administradores de companhias abertas em utilizá-los não deveria ser revista pelo Judiciário, em referência expressa ao padrão de revisão (standard of review) da business judgement rule, que será melhor examinado no item 8.5.

O julgamento do caso Moran $v$. Household formulou algumas premissas a serem observadas na utilização dos planos de poison pill e, até mesmo, nas medidas defensivas em geral, recomendando-se que as mesmas devam ser instrumentos de defesa proporcionais à ameaça contra a qual pretendem ser utilizadas.

Adicionalmente, a adoção de tais defesas pela administração da companhiaalvo pressupõe devida informação e conhecimento, pelos administradores, em relação às defesas e aos efeitos delas decorrentes.

\footnotetext{
263 No caso Moran v. Household International, Inc. (500 A.2.d 1346, Delaware, 1985, Rel. John J. McNeilly), a Household International Inc. ("Household”), companhia com grande dispersão acionária, concedeu aos seus acionistas uma opção de compra, através de plano de poison pill, na modalidade flip over. Caso qualquer terceiro e/ou acionista: (i) adquirisse 20\% do capital social da Household ou (ii) fizesse uma oferta pública para aquisição de ações representativas de 30\% ou mais da Household e, em seguida, incorporasse a Household ou se incorporasse a esta última, cada um dos acionistas da Household teria o direito de adquirir ações da sociedade resultante de tal operação pela metade do preço. O plano de poison pill da Household atribuía ao Conselho de Administração poderes para resgatar os direitos atribuídos por meio de tal plano, com a subsequente extinção do mesmo. O plano de poison pill da Household era uma medida defensiva preventiva, vigente antes mesmo da existência de uma tentativa de tomada de controle da Household. O objetivo principal de tal defesa era opor-se às temidas "two-tier takeover", sobre as quais tratamos na exposição histórica do item 4.2.

${ }^{264} \mathrm{O}$ caso Moran v. Household International, Inc. (500 A.2.d 1346, Delaware, 1985, Rel. John J. McNeilly) estabeleceu importantes parâmetros não apenas em relação às poison pills, mas também para as demais espécies de medidas defensivas em geral.
} 
As medidas defensivas não podem representar óbice absoluto e instransponível à tomada de controle, formando-se o entendimento, com o julgamento do caso Moran $v$. Household, de que as medidas defensivas não podem impedir completamente e tornar impossível a tomada de controle, mas devem funcionar como método capaz de estruturar a defesa contra a tomada de controle hostil.

Feitas estas digressões sobre o importante caso Moran v. Household, retome-se o exame dos planos de poison pill, com especial atenção à feição atual dos mesmos ${ }^{265}$, que podem assumir diversas formas e contemplar inúmeros programas em seu conteúdo.

Respeitadas as especificidades existentes em cada caso concreto, os planos de poison pill têm reconhecidamente algumas características essenciais em comum, quais sejam: (i) o fato de a tentativa de tomada de controle da companhia-alvo funcionar como "gatilho" para que tal medida defensiva possa ser utilizada; e (ii) a possibilidade de que, embora ocorra a tentativa de tomada de controle, a "bomba" contida no plano de poison pill possa ser desarmada, seja pela administração e/ou por deliberação em assembleia geral, conforme a sistemática de alocação do poder-dever de decidir quanto à medida defensiva.

Esta característica da possibilidade de “desarme” da poison pill a torna um mecanismo de defesa eficiente no propósito de auxiliar na negociação de melhores condições para que a tomada de controle seja realizada. Negocia-se o "desarme” da medida defensiva em contrapartida ao aumento do valor da oferta inicialmente realizada e/ou outra forma de melhora na oferta inicialmente feita aos acionistas.

Jeffrey Gordon ${ }^{266}$, sob a perspectiva do direito norte-americano, expõe que a poison pill funciona como um mecanismo eficiente para o aumento do poder de barganha

\footnotetext{
${ }^{265}$ Plínio José Lopes Shimegatsu faz interessante resumo das três gerações de poison pills nos EUA, quais sejam: (a) a preferred stock plans (primeira geração); (b) a flip-over rights (segunda geração); e (c) a shareholders rights plans (terceira geração). (SHIMEGATSU, Plínio José Lopes. Mecanismos de proteção e estratégias de defesa em tomadas hostis de controle. In: CASTRO, Rodrigo R. Monteiro; ARAGÃO, Leandro Santos de. Direito Societário: Desafios Atuais. São Paulo: Quartier Latin, 2009, especialmente em pp. 403406).

${ }^{266}$ De acordo com Jeffrey Gordon, "the pill, because redeemable, has become a channeling mechanism that structures a bargaining process. It forces a bidder to negotiate with the board instead of its preferred strategy of making an offer directly to the shareholders” (GORDON, Jeffrey N. An American Perspective on AntiTakeover Laws in the EU: The German Example. In: FERRARINI, Guido et al. (org.). Reforming Company and Takeover Law in Europe. Oxford: Oxford University Press, 2004, p. 552. Disponível em: $<$ http://ssrn.com/abstract=336420 $>$. Acesso em: 12.12.2009.
} 
da administração da companhia-alvo, capaz de estruturar a negociação diante de uma tentativa de tomada de controle. O ofertante negocia com a administração da companhiaalvo o desarme da poison pill, em vez de realizar a operação diretamente com os acionistas, por meio de oferta pública de aquisição de ações.

A possibilidade de desarme da medida defensiva é, fundamentalmente, um dos marcos distintivos característicos de que as cláusulas estatutárias de “proteção à dispersão acionária”, examinadas no item 6.2 deste trabalho, não são poison pills clássicos.

Os planos de poison pill podem se apresentar em diferentes versões, cada uma delas com peculiaridades próprias, mas sempre preservando as duas características essenciais expostas acima, quais sejam: (i) a tentativa de tomada de controle funcionar como "gatilho" para a utilização da medida defensiva; e (ii) a possibilidade de "desarme" da medida defensiva.

Expondo sobre a diversidade de modelos possíveis de poison pills, Robert Clark $^{267}$ destaca a existência de planos de poison pill que envolvem direitos de conversão, direitos de resgate e direitos de subscrição, sempre desarmáveis e efetivos tão-somente diante da tentativa de takeover. Jeffrey D. Bauman, Elliot J. Weiss e Alan R. Palmiter ${ }^{268}$ expõem que, geralmente, tais direitos podem ser resgatados, por deliberação da administração, antes de eventual oferta pública para aquisição de controle.

Nas palavras do autor português Luís Menezes Leitão, a poison pill estabelece que “a oferta pública de aquisição de um determinado número de acções da sociedade visada sem aprovação do órgão de administração atribui aos restantes accionistas especiais direitos de aquisição ou subscrição de ações ${ }^{269}$ ", normalmente, a preços bastante inferiores aos de mercado ${ }^{270}$.

\footnotetext{
${ }^{267}$ CLARK, Robert Charles. Corporate Law. Boston / Toronto: Little, Brown and Company, 1986, pp. 574575.

${ }^{268}$ BAUMAN, Jeffrey D.; WEISS, Elliot J.; PALMITER, Alan R. Corporations - Law and Policy Materials and Problems. 5. ed. Saint Paul: Thomson - West Group, 2003, p. 1103.

${ }^{269}$ LEITÃO, Luís Manuel Teles de Menezes. As medidas defensivas contra uma oferta pública de aquisição hostil. O Direito. Ano 138, t. III, Coimbra: Almedina, 2006, p. 463.

${ }^{270}$ BAUMAN, Jeffrey D.; WEISS, Elliot J.; PALMITER, Alan R. Op. cit., p. 1103.
} 
Os planos de poison pill têm como efeito diluir a participação acionária detida pelo potencial adquirente do controle da companhia-alvo ${ }^{271}$, criando dificuldades para que este obtenha o controle de tal sociedade. Além disto, tais medidas defensivas suscitam obrigações que tornam o esforço de tomada de controle mais oneroso, fazendo necessária a aplicação de recursos em maior volume para que se tenha êxito na operação ${ }^{272}$.

No Brasil, a adoção de planos de poison pill clássicos é altamente questionável e, sob o ponto de vista jurídico, deve ser avaliada com ressalvas para não caracterizar violação às determinações legais e/ou regulatórias, notadamente aquelas contidas na Lei ${ }^{\circ}$ 6.404/76 e nas normas expedidas pela CVM, de modo a viabilizar a utilização de tal defesa.

Como sugere o provérbio de Paracelsus, há de se ter cuidado na dosagem do plano de poison pill, pois “a diferença entre o remédio e o veneno é a dose”.

Na doutrina pátria, sem aprofundar-se no tema, Carlos Augusto Silveira Lobo reputa as poison pills como medidas defensivas ilícitas ${ }^{273}$. Com maior análise, Fábio Konder Comparato e Calixto Salomão Filho consideram duvidosa a admissibilidade e efetividade das poison pills no Brasil, que, segundo eles, talvez não sobrevivam ao exame à luz do direito civil, que reputaria meramente potestativa a cláusula que autoriza o resgate da poison pill pela administração, em violação ao disposto no artigo 122 , §1 ${ }^{\circ}$, do Código Civil $^{274}$.

Analisando-os, parece-nos que os planos de poison pill que contemplem previsão de que a tentativa de tomada de controle da companhia-alvo autorizará a administração desta última a realizar recompra de ações de sua própria emissão, seguindo o costume usualmente adotado em inúmeros planos de poison pill na experiência norte-

\footnotetext{
${ }^{271}$ LEITÃO, Luís Manuel Teles de Menezes. As medidas defensivas contra uma oferta pública de aquisição hostil. O Direito. Ano 138, t. III, Coimbra: Almedina, 2006, p. 463.

272 BAUMAN, Jeffrey D.; WEISS, Elliot J.; PALMITER, Alan R. Corporations - Law and Policy Materials and Problems. 5. ed. Saint Paul: Thomson - West Group, 2003, p. 1103.

${ }^{273}$ LOBO, Carlos Augusto da Silveira. Sociedades coligadas, controladoras e controladas. In: LAMY FILHO, Alfredo; BULHÕES PEDREIRA, José Luiz. Direito das Companhias. v. 2, Rio de Janeiro: Forense, 2009, pp. 2034-2035.

${ }^{274}$ COMPARATO, Fábio Konder; SALOMÃO FILHO, Calixto. O Poder de Controle na Sociedade Anônima. 4. ed. Rio de Janeiro: Forense, 2005, p. 251.
} 
americana, não podem ser utilizados no Brasil, em respeito às determinações do artigo $2^{\circ}$ da Instrução CVM no 10/80.

O referido artigo $2^{\circ}$ da Instrução CVM nº 10/80 prescreve que “a aquisição, de modo direto ou indireto, de ações de emissão da companhia, para permanência em tesouraria ou cancelamento, é vedada quando: [...] estiver em curso oferta pública de aquisição de suas ações”. Portanto, não seria possível realizar a recompra de ações se houvesse sido iniciada a oferta pública de aquisição de ações, por meio da qual se pretende empreender a tomada de controle ${ }^{275}$.

Além disso, em respeito ao $\S 1^{\circ}$ do artigo 109 da Lei ${ }^{\circ}$ 6.404/76, dificilmente funcionaria no sistema jurídico brasileiro alguma defesa que contivesse características de tratamento desigual entre acionistas detentores de mesma espécie e classe de ações, pelas razões expostas no item 5.2.

Outro plano clássico de poison pill, frequentemente utilizado nos EUA, por meio do qual se atribui aos acionistas da companhia-alvo direitos de aquisição ou subscrição de ações de emissão da própria companhia-alvo a preços inferiores aos praticados pelo mercado, dificilmente poderia ser adotado no Brasil, a menos que fosse submetido a severas adaptações ao nosso sistema.

A invalidade de tais planos clássicos de poison pill estaria intimamente relacionada com a fixação do preço de emissão de ações em aumentos de capital da companhia-alvo, que, no Brasil, deve observar as disposições do artigo 170 da Lei $\mathrm{n}^{\circ}$ 6.404/76 e do Parecer de Orientação CVM n 01/78, sendo incompatíveis com o nosso sistema os planos de poison pill que seletivamente contemplem critérios mais benéficos para a subscrição de ações em aumentos de capital da companhia-alvo ${ }^{276}$.

\footnotetext{
${ }^{275}$ A legislação penal comina sanção ao administrador que recomprar ação de emissão da companhia, quando tal operação não estiver legalmente permitida. Neste sentido, o artigo 177, §1 ${ }^{\circ}$, inciso IV, do Código Penal prevê que incorre em pena de reclusão, de um a quatro anos, e multa, "[...] o diretor ou o gerente que compra ou vende, por conta da sociedade, ações por ela emitidas, salvo quando a lei o permite”.

${ }^{276}$ Socorremo-nos da excelente análise de Mauro Rodrigues Penteado em relação às regras aplicáveis aos aumentos de capital nas sociedades anônimas (PENTEADO, Mauro Rodrigues. Aumento de Capital das Sociedades Anônimas. São Paulo: Saraiva, 1988).
} 
Os planos de poison pill se dividem nas subespécies de flip in e flip over, que têm como principal distinção a companhia em relação à qual o direito contido no plano de poison pill será exercido. As poison pills de flip in destinam-se à diluição da companhiaalvo, enquanto as poison pills de flip over atribuem direitos em relação à companhia ofertante.

\subsubsection{FLIP IN}

A poison pill de modalidade flip in consiste em mecanismo de defesa por meio do qual determinados acionistas da companhia-alvo, interessados em manter o controle em relação a esta última, empreendem esforços e utilizam-se de direitos que lhe são conferidos pelo plano de poison pill para: (i) diluir o potencial adquirente interessado na tomada de controle; e/ou (ii) aumentar a quantidade de ações que o ofertante deverá adquirir para tomar o controle.

Em regra, a diluição do potencial adquirente do controle e/ou o aumento da quantidade de ações a serem adquiridas para a tomada do controle, dar-se-á paralelamente à elevação da participação acionária detida pelos acionistas interessados na manutenção do controle.

Nas poison pills de flip in, a companhia-alvo permite aos seus acionistas, com exclusão do ofertante ${ }^{277}$, a possibilidade de: (i) adquirirem ações de emissão da companhia-alvo, mantidas em tesouraria, por um preço inferior ao valor do mercado, dificultando-se a obtenção do controle ${ }^{278}$; ou (ii) subscreverem ações a serem emitidas em

\footnotetext{
${ }^{277}$ BAUMAN, Jeffrey D.; WEISS, Elliot J.; PALMITER, Alan R. Corporations - Law and Policy Materials and Problems. 5. ed. Saint Paul: Thomson - West Group, 2003, p. 1103.

${ }^{278}$ LEITÃO, Luís Manuel Teles de Menezes. As medidas defensivas contra uma oferta pública de aquisição hostil. O Direito. Ano 138, t. III, Coimbra: Almedina, 2006, p. 463.
} 
aumento do capital social da companhia-alvo, por valores inferiores aos praticados pelo mercado $^{279}$.

A poison pill, em qualquer de suas modalidades (i.e., flip in e flip over), comporta variações. Pode-se conceber, por exemplo, poison pills de flip in em que a tentativa de tomada de controle propiciará meios para que os detentores de valores mobiliários de emissão da companhia-alvo, conversíveis em ações, realizem tal conversão, consequentemente diluindo o potencial adquirente do controle da companhia-alvo.

A utilização da poison pill de flip in no Brasil certamente deverá ser submetida a adequações, de modo a enquadrar-se na realidade jurídica de nosso sistema.

Empreendendo esforço de compatibilização à sistemática pátria, pode-se ponderar pela utilização de bônus de subscrição e/ou planos de opção de compra como métodos capazes de alcançar, entre nós, efeitos semelhantes àqueles pretendidos pelas poison pills de flip $\mathrm{in}^{280}$.

\subsubsection{BôNUS DE SUBSCRIÇÃo}

Os bônus de subscrição são valores mobiliários de emissão privativa de companhias de capital autorizado ${ }^{281}$, que conferem aos seus titulares o direito de, nas

\footnotetext{
${ }^{279}$ William Allen e Reinier Kraakman noticiam que há casos em que a subscrição é feita pela metade do valor de mercado das ações (ALLEN, William T.; KRAAKMAN, Reinier. Commentaries and Cases on the Law of Business Organization. Nova York: Aspen Publishers, 2003, p. 507).

${ }^{280}$ Há na doutrina pátria análise ainda embrionária da questão, mas direcionada para o mesmo sentido da proposta por nós apresentada. Plínio José Lopes Shimegatsu reconhece no "aumento do capital autorizado" uma medida defensiva a ser possivelmente adotada contra a tomada de controle (SHIMEGATSU, Plínio José Lopes. Mecanismos de proteção e estratégias de defesa em tomadas hostis de controle. In: CASTRO, Rodrigo R. Monteiro; ARAGÃO, Leandro Santos de. Direito Societário: Desafios Atuais. São Paulo: Quartier Latin, pp. 389-440, 2009, p. 423).

${ }^{281}$ A companhia de capital autorizado é aquela que contém autorização estatutária para aumento do capital social, independentemente de reforma estatutária, nos termos do artigo 168 da Lei ${ }^{\circ}$ 6.404/76. Em nosso raciocínio, tendente a analisar juridicamente a utilização dos bônus de subscrição e das opções de compra como adaptações pátrias para a aplicação das poison pills de flip in, a atribuição da competência ao Conselho de Administração para a realização de aumentos de capital mediante os bônus de subscrição e planos de opção de compra são elementos a serem considerados na utilização casuística de tais instrumentos como medidas defensivas. Das lições de José Alexandre Tavares Guerreiro, podem ser também extraídos
} 
condições constantes do certificado emitido no ato de sua criação, subscrever ações de emissão da companhia, mediante o pagamento do respectivo preço de emissão.

Os bônus de subscrição são regulados pelos artigos 75 a 79 da Lei nº 6.404/76, tendo como principal característica assegurar ao seu titular o direito de subscrever ações a serem emitidas por preço de emissão, estabelecido à época da alienação do bônus de subscrição pela companhia e/ou de sua atribuição aos seus titulares, como vantagem adicional, em subscrições de emissões de ações e/ou debêntures (artigo 77 da Lei $n^{\circ}$ $6.404 / 76)$.

Ao tornar-se proprietário do bônus de subscrição, o titular tem a expectativa de que, no momento do exercício dos direitos contidos em tal valor mobiliário, as ações de emissão da companhia estarão sendo negociadas no mercado por valores superiores ao preço fixado no ato da emissão do bônus de subscrição.

De acordo com o artigo 77, parágrafo único, da Lei nº 6.404/76, “os acionistas da companhia gozarão, nos termos dos artigos 171 e 172 da Lei n ${ }^{\circ}$ 6.404/76, de preferência para subscrever a emissão de bônus”. O $\S 3^{\circ}$ do artigo 171 da Lei $n^{\circ}$ 6.404/76 reitera a existência do direito de preferência dos acionistas para a subscrição de bônus de subscrição e estabelece que no exercício dos direitos inerentes ao bônus de subscrição não haverá direito de preferência.

Portanto, uma vez respeitado o direito de preferência na emissão do bônus de subscrição, os aumentos de capital que vierem a ser realizados posteriormente para a emissão de ações no exercício do bônus de subscrição serão realizados sem direito de preferência.

Analisando os bônus de subscrição à luz das táticas defensivas contra tomadas de controle, especialmente os planos de poison pill na modalidade flip in, observa-se que

interessantes fundamentos neste sentido, uma vez que “[...] os aumentos efetuados sob o art. 168 podem ser

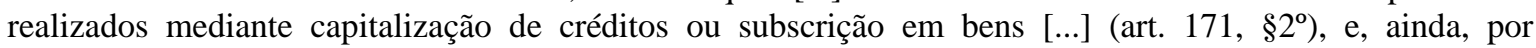
conversão, em ações, de debêntures ou partes beneficiárias e pelo exercício de direitos conferidos por bônus de subscrição, ou de opção de compra de ações (art. 166, III)” (GUERREIRO, José Alexandre Tavares. Regime Jurídico do Capital Autorizado. São Paulo: Saraiva, 1984, pp. 82-83). Desta maneira, os bônus de subscrição e os planos de opção de compra são instrumentos disponíveis para a realização de aumento de capital, com potencial tratamento benéfico aos detentores do bônus de subscrição ou beneficiários do plano de opção de compra. 
estes podem servir como mecanismo adotado para dificultar a tomada de controle da companhia-alvo, mediante aumento de seu capital social: (i) diluindo a participação acionária detida pelo potencial adquirente interessado na tomada de controle; e/ou (ii) aumentando a quantidade de ações que o ofertante deverá adquirir para tomar o controle da companhia-alvo; paralelamente elevando a participação acionária detida pelos acionistas interessados na manutenção do controle na companhia-alvo.

Pode-se conceber, por hipótese, caso em que bônus de subscrição são atribuídos como vantagem adicional aos subscritores de aumento de capital realizado em estágio inicial do desenvolvimento da companhia-alvo, nos termos do artigo 77 da Lei ${ }^{\circ}$ 6.404/76. A atribuição do bônus de subscrição dar-se-á respeitando o direito de preferência dos demais acionistas da companhia-alvo, atendendo ao parágrafo único do artigo 77 e o $\S 3^{\circ}$ do artigo 171 da Lei $n^{0}$ 6.404/76. O preço de emissão das ações para o exercício do bônus de subscrição será estabelecido à época da atribuição do bônus de subscrição, respeitando o disposto no artigo $170, \S 1^{\circ}$, da Lei $n^{\circ} 6.404 / 76$, mas a expectativa que se tem é de que este preço de emissão, estabelecido na fase embrionária da companhia-alvo, se revele vantajoso para o futuro. Em tal hipótese, os detentores do bônus de subscrição estarão investidos de instrumento que, dependendo da quantidade de ações a que tenha direito de subscrever, poderá representar defesa efetiva contra potencial tomada de controle da companhia-alvo.

De modo a tornar o bônus de subscrição, com as características ora analisadas, uma medida defensiva destinada a desempenhar no Brasil função semelhante àquela das poison pills de flip in, o capital autorizado deve ser suficiente para assegurar a emissão de ações em quantidade capaz de defender contra a tomada de controle.

Interessante notar que, à luz das reflexões sobre a sistemática de alocação do poder-dever de decidir quanto à utilização da medida defensiva, o estatuto social da companhia-alvo pode atribuir ao Conselho de Administração a competência para a emissão de bônus de subscrição, tal como prescreve o artigo 76 da Lei $n^{\circ}$ 6.404/76. Além disso, o estatuto social poderá deslocar para o Conselho de Administração a competência para 
deliberar sobre as emissões de ações no âmbito do capital autorizado, conforme prevê o artigo 168, §1º, alínea “b”, da Lei no 6.404/76 $6^{282}$.

Portanto, há mecanismos que permitem que a defesa mediante utilização de bônus de subscrição seja conduzida pelo Conselho de Administração.

\subsubsection{Plano de OPÇÃo de CoMPra de AÇõES}

A Lei ${ }^{0} 6.404 / 76$, em seu artigo $168, \S 3^{\circ}$, estabelece que, dentro do limite do capital autorizado, o estatuto social pode prever que a companhia, de acordo com o plano aprovado pela assembleia geral, outorgue opção de compra aos seus administradores, empregados ou pessoas naturais que prestem serviços à companhia ou para sociedade sob seu controle.

Paulo Cezar Aragão expõe que "a opção de compra de ações representa um direito, de natureza contratual, com base no qual o seu titular [...] pode subscrever, nas condições aprovadas pela assembléia geral, ações de emissão da companhia, pagando o preço" $^{283}$.

Da mesma forma que ocorre com o bônus de subscrição, a opção de compra de ações também assegura ao seu titular o direito de subscrever futuramente ações da companhia, por um preço de emissão previamente estabelecido à época da outorga da opção de compra.

\footnotetext{
${ }^{282}$ Mauro Rodrigues Penteado ensina que "no regime do capital autorizado a decisão acerca da emissão de ações poderá ser adotada tanto pela assembléia geral extraordinária quanto pelo conselho de administração, conforme dispuser o estatuto (arts. 166, II e 168, §1 ${ }^{\circ}, b$ )" (PENTEADO, Mauro Rodrigues. Aumento de Capital das Sociedades Anônimas. São Paulo: Saraiva, 1988, p. 188).

${ }^{283}$ ARAGÃO, Paulo Cezar. Opções de compra de ações e bônus de subscrição. Revista dos Tribunais. São Paulo: RT, n. 631, pp. 63-70, mai. 1988, p. 63. No trabalho em destaque, o eminente advogado faz interessante correção conceitual em relação à impropriedade terminológica da opção de compra de ações, esclarecendo que "o titular da opção não está comprando ações, em sentido estrito, mas antes subscrevendo novas ações”.
} 
O bônus de subscrição e a opção de compra possuem muitas semelhanças e, conforme apontam José Luiz Bulhões Pedreira e Alfredo Lamy Filho, a grande distinção 284 entre eles é o fato de que o bônus de subscrição “é um valor mobiliário, enquanto a opção de compra é um contrato intuitu personae ${ }^{285}$.

Os parâmetros estabelecidos no artigo 170, §1º da Lei $n^{\circ}$ 6.404/76 deverão ser respeitados à época da fixação do preço de emissão das ações, concomitantemente à outorga da opção de compra, sendo que tal outorga pressupõe a existência de previsão estatutária e existência de plano de opção de compra aprovado pela assembleia geral.

Em regra, a outorga das opções de compra visa a permitir que administradores, empregados ou pessoas naturais que prestem serviços à companhia ou para sociedade sob seu controle participem, em conjunto com os acionistas, da valorização do patrimônio social, com o objetivo de estimular o comprometimento do beneficiário da opção de compra com a obtenção de resultados pela companhia. O plano de opção de compra de ações que não estiver alinhado com este comprometimento sujeitar-se-á à configuração de abuso de poder de controle, nos termos do artigo $1^{\circ}$, inciso XII, da Instrução CVM ${ }^{\circ}$ $323 / 00^{286}$.

Os aumentos de capital realizados para exercício da opção de compra, assim como aqueles realizados para o exercício do bônus de subscrição, serão efetivados, sem a existência de direito de preferência aos demais acionistas, de acordo com o §3º do artigo 171 da Lei $n^{\circ}$ 6.404/76. No caso das opções de compra, por suas próprias características e

\footnotetext{
${ }^{284}$ Tratando das distinções existentes entre bônus de subscrição e opções de compra de ações, Paulo Cezar Aragão pontua que "há outra diferença relevante: quando da criação de bônus de subscrição, a companhia é obrigada a conceder direito de preferência aos seus acionistas para a aquisição dos mesmos bônus; no caso da opção de compra, ao contrário, não existe este direito de preferência em nenhuma circunstância” (ARAGÃO, Paulo Cezar. Opções de compra de ações e bônus de subscrição. Revista dos Tribunais. São Paulo: RT, n. 631, pp. 63-70, mai. 1988, p. 63).

${ }^{285}$ LAMY FILHO, Alfredo; BULHÕES PEDREIRA, José Luiz. Direito das Companhias. v. 1, Rio de Janeiro: Forense, 2009, p. 647.

${ }^{286} \mathrm{O}$ artigo $1^{\circ}$ da Instrução CVM n ${ }^{\circ} 323 / 00$ estabelece que "são modalidades de exercício abusivo do poder de controle de companhia aberta, sem prejuízo de outras previsões legais ou regulamentares, ou de outras condutas assim entendidas pela CVM: [...] XII - a instituição de plano de opção de compra de ações, para administradores ou empregados da companhia, inclusive com a utilização de ações adquiridas para manutenção em tesouraria, deixando a exclusivo critério dos participantes do plano o momento do exercício da opção e sua venda, sem o efetivo comprometimento com a obtenção de resultados, em detrimento da companhia e dos acionistas minoritários”.
} 
por destinar-se a beneficiários específicos, o direito de preferência não se aplica nem mesmo na outorga da opção de compra ${ }^{287}$.

\subsubsection{FLIP OVER}

A poison pill de modalidade flip over consiste em mecanismo de defesa, por meio do qual são atribuídos direitos aos acionistas da companhia-alvo, que lhes assegurarão proteção em caso de tentativa de tomada de controle desta última por algum terceiro, mediante aquisição de ações de tal terceiro por preço significativamente abaixo do valor de mercado.

O autor português Luís Menezes Leitão expõe que, na modalidade flip over, tática originalmente utilizada nos planos de poison pill ${ }^{288}$, “a sociedade visada concede aos seus acionistas o direito de adquirir acções do próprio oferente a um preço mais reduzido após a aquisição, procurando assim transferir o controlo do oferente para os seus próprios acionistas" $^{289}$.

Caso um ofertante adquira ações de determinada companhia-alvo, em volume que lhe assegure participação acionária expressiva, e, subsequentemente, realize operação de concentração empresarial (exemplificativamente, fusão, incorporação ou incorporação de ações), os direitos atribuídos aos acionistas da companhia-alvo poderão ser exercidos.

Assegura-se, assim, que tal operação de concentração empresarial somente poderá ser realizada se garantir aos acionistas da companhia-alvo uma relação de substituição em que lhes sejam atribuídas ações da companhia resultante da concentração empresarial por valor descontado em relação ao preço de mercado de tais ações.

\footnotetext{
${ }^{287}$ Vide nota de rodapé 284.

288 ALLEN, William T.; KRAAKMAN, Reinier. Commentaries and Cases on the Law of Business Organization. Nova York: Aspen Publishers, 2003, p. 507.

${ }^{289}$ LEITÃO, Luís Manuel Teles de Menezes. As medidas defensivas contra uma oferta pública de aquisição hostil. O Direito. Ano 138, t. III, Coimbra: Almedina, 2006, p.463.
} 
Os países em que há adoção de poison pills na modalidade flip over, notadamente os EUA, adotam o pressuposto de que a companhia resultante da operação de concentração empresarial será sucessora universal, em todos os direitos e obrigações das companhias extintas em tal operação, e, consequentemente, será responsável por honrar o direito de conversão atribuído aos acionistas da companhia-alvo, tornando o poison pill de flip over juridicamente exequível.

Usualmente, as poison pills em sua versão de flip over têm seu "gatilho" apenas em caso de uma incorporação da companhia-alvo pelo ofertante, subsequentemente à aquisição de participação acionária acima de determinado percentual de participação acionária da companhia-alvo (usualmente 20\%), tendo como objetivo essencial assegurar aos acionistas da companhia-alvo o direito de adquirir ações do ofertante com expressivo desconto. O propósito essencial das poison pills de flip over é restringir as two-tier takeovers e reduzir a pressão coercitiva associada às mesmas.

Portanto, como ensinam Jesse Choper, John Coffee Jr. e Ronald Gilson ${ }^{290}$, a experiência prática nos EUA tem revelado que inúmeros planos de poison pill atualmente contemplam características tanto de flip-in quanto de flip-over.

Em relação à utilização da poison pill de flip over no Brasil, entendemos haver grandes dificuldades para que a medida defensiva contida em uma companhia produza efeitos em relação à outra companhia.

Entre nós, vigora a regra do artigo 227 da Lei $n^{\circ}$ 6.404/76, que prescreve que a companhia incorporadora será sucessora, a título universal, em todos os direitos e obrigações, da companhia incorporada. Desta maneira, há meios para seguir o raciocínio aplicável aos EUA. Entretanto, tal sucessão somente se aplicaria após a realização da incorporação, o que não obrigaria a companhia incorporadora a, previamente à incorporação, respeitar tal regra que importará em atribuir aos acionistas da sociedade

\footnotetext{
${ }^{290}$ Os doutrinadores norte-americanos Jesse Choper, John Coffee Jr. e Ronald Gilson ensinam que “[t]oday, the terms 'flip-over' and 'flip-in' are used loosely to characterize two different varieties of poison pills (although any given security may contain elements of both)" (CHOPER, Jesse H.; COFFEE Jr., John C.; GILSON, Ronald J. Cases and materials on corporations. 7. ed. Nova York: Aspen Publishers, 2008, p. 952).
} 
incorporada ações da companhia incorporadora em quantidades superiores àquelas que lhes seriam atribuídas se não houvesse tal disposição.

Além disso, em condições normais, o respeito à poison pill de flip over no Brasil pode ser atentatório aos direitos dos acionistas da sociedade incorporadora que receberão tratamento menos favorecido do que aquele aplicável aos acionistas que ingressarão da sociedade incorporada, após a conclusão de tal operação.

Parece-nos que a poison pill de flip over é inaplicável entre nós. A ideia nela contida pode, tão-somente, servir de inspiração às administrações das sociedades incorporadas e incorporadoras ao acordarem as relações de substituição em operações de incorporação levadas a efeito subsequentemente a ofertas públicas de aquisição de ações, a fim de dirimir potencial descontentamento pelos acionistas remanescentes da companhia, cujo controle houver sido adquirido pela oferta pública.

Se, de um lado, a poison pill de flip over não é aplicável entre nós; de outro lado, as two-tier takeovers, que são o ataque ao qual esta defesa se contrapõe, dificilmente seriam admissíveis no Brasil ${ }^{291}$.

No Brasil, há uma recente e notória febre de inserção nos estatutos sociais de companhias abertas de cláusulas de proteção à dispersão acionária, as quais vêm sendo equivocadamente chamadas de poison pills ${ }^{292}$.

\footnotetext{
291 Vide nota de rodapé 151.

292 Erica Gorga tem noticiado à comunidade jurídica mundial sobre a existência das cláusulas de proteção à dispersão acionária no Brasil, apontando a mesma distinção feita por nós entre esta espécie de defesa e os planos de poison pill, nos seguintes termos: "In Brazil, the predominant takeover defense is a provision in the company's charter that allows current shareholders to sell their shares to an acquirer who attains a critical limit of target's shares. In this sense it resembles the mandatory tender offer required by law but is triggered by a lower threshold of shares' acquisition. Nonetheless, the media calls this defense a poison pill. Yet this type of takeover defense might not completely stop a determined acquirer. Instead, it ensures minority shareholders the right to tender their shares at a fair price if they think this is a good time to sell. This strategy also makes the target acquisition much more expensive to the bidder" (GORGA, Erica. Changing the
} 
Conforme examinamos no item 6.1, as cláusulas de proteção à dispersão acionária, embora desempenhem função de dificultar a tomada de controle na maioria dos casos, são totalmente distintas dos planos de poison pill clássicos. O “efeito venenoso” das poison pill clássicas é diferente da consequência decorrente da aplicação das cláusulas estatutárias de proteção à dispersão acionária, que vêm sendo utilizadas no Brasil.

De um lado, as poison pill clássicas estabelecem que o acionista que ensejou o “disparo” da poison pill estará excluído do plano de direito atribuíveis aos acionistas, não lhe sendo permitido exercer direitos de aquisição ou subscrição de ações a preços inferiores àqueles praticados pelo mercado.

De outro lado, as cláusulas estatutárias de proteção à dispersão acionária, em sua versão mais extrema, abaixo referida como "Tipo A", estabelecem que o acionista que adquirir ações em quantidade igual ou superior a determinado percentual de participação acionária deverá realizar oferta pública para aquisição da totalidade das demais ações de emissão da companhia.

O exame das cláusulas de discutida proteção à dispersão acionária espalhadas em estatutos sociais de companhias abertas brasileiras revela a existência de 2 (duas) formas prevalentes de disposições estatutárias.

A versão mais usual ${ }^{293}$ de tais cláusulas, referida em pesquisa recente como “Tipo A”, a qual enseja as consequências mais extremas, prevê que se qualquer acionista da companhia adquirir ou, de qualquer outro modo, se tornar titular de ações de emissão da

Paradigm of Stock Ownership: From Concentrated Towards Dispersed Ownership? Evidence from Brazil and Consequences for Emerging Countries. 3rd Annual Conference on Empirical Legal Studies Papers. Abr. 2008. Disponível em SSRN: <http://ssrn.com/abstract=1121037>. Acesso em 12.12.2009).

293 Dentre as companhias abertas que adotam cláusulas de proteção à dispersão acionária, a excelente pesquisa de campo empreendida por Erica Gorga revela que dentre 84 (oitenta e quatro) companhias abertas submetidas à análise, 43 (quarenta e três) possuíam a cláusula estatutária com estas características (Tipo A), sendo que destas 43 (quarenta e três), 12 (doze) companhias abertas apresentavam características tanto do “Tipo A" quanto do "Tipo B”. O estudo revela ainda que apenas 4 (quatro) companhias abertas apresentavam características exclusivamente do "Tipo B”. Para maiores informações, referir-se a GORGA, Erica. Changing the Paradigm of Stock Ownership: From Concentrated Towards Dispersed Ownership? Evidence from Brazil and Consequences for Emerging Countries. 3rd Annual Conference on Empirical Legal Studies Papers. Abr. 2008. Disponível em SSRN: <http://ssrn.com/abstract=1121037>. Acesso em 12.12.2009, com especial atenção à tabela que constitui o Anexo 26 de tal estudo. 
companhia, em quantidade igual ou superior a determinado percentual ${ }^{294}$ do total de ações, este acionista deverá realizar oferta pública de aquisição de ações (OPA) para adquirir a totalidade das ações de emissão da companhia.

Há também as cláusulas de proteção à dispersão acionária, com consequências menos extremas, referidas em pesquisa recente como "Tipo B", que determinam que se qualquer terceiro adquirir ou, de qualquer outro modo, tornar-se titular de ações de emissão da companhia, em quantidade igual ou superior a determinado percentual ${ }^{295}$ do total de ações, este acionista deverá comunicar ao Diretor de Relação com Investidores (DRI) da companhia e/ou ao diretor de pregão da bolsa de valores, por meio da sociedade corretora pela qual pretenda adquirir ações, sua intenção de adquirir outras ações de emissão da companhia, de modo que o diretor de pregão da bolsa de valores possa previamente convocar um leilão de compra, a ser realizado em pregão da bolsa de valores, do qual possam participar terceiros interferentes e/ou eventualmente a própria companhia.

São também comuns a existência de cláusulas de proteção à dispersão acionária que combinam características tanto do “Tipo A” quanto do “Tipo B”. Em tais casos, se qualquer acionista da companhia adquirir ou, de qualquer outro modo, se tornar titular de ações de emissão de tal companhia aberta, em quantidade igual ou superior a determinado percentual do total de ações, este acionista deverá: (i) realizar oferta pública

\footnotetext{
${ }^{294}$ Analisando os estatutos sociais das companhias abertas brasileiras disponíveis no domínio da CVM na Internet, em busca de evidências empíricas especialmente em relação àquelas companhias listadas em segmentos especiais da BM\&F-Bovespa, constata-se que: (i) dentre as companhias listadas no Novo Mercado da BM\&F-Bovespa este percentual de participação acionária que determina a obrigação de realizar oferta pública aos demais acionistas varia entre o mínimo de 10\% (dez por cento) (caso, por exemplo, da Positivo Informática S.A. e da São Martinho S.A.) e o máximo de 35\% (trinta e cinco por cento) (caso, por exemplo, da Companhia Brasileira de Desenvolvimento Imobiliário e Turístico); e (ii) dentre as companhias listadas no Nível 2 da BM\&F-Bovespa este percentual de participação acionária que determina a obrigação de realizar oferta pública aos demais acionistas varia entre o mínimo de 15\% (quinze por cento) (caso, por exemplo, da Kroton Educacional S.A.) e o máximo de 20\% (vinte por cento) (caso, por exemplo, da Multiplan S.A. e da Santos Brasil S.A.). Até 12.12.2009, não há companhias listadas no Nível 1 da BM\&F-Bovespa com tais cláusulas de proteção à dispersão acionária (Disponível em <www.cvm.com.br> . Acesso em 12.12.2009).

${ }^{295}$ Analisando os estatutos sociais das companhias abertas brasileiras disponíveis no domínio da CVM na Internet, em busca de evidências empíricas especialmente em relação àquelas companhias listadas em segmentos especiais da BM\&F-Bovespa, constata-se que dentre as companhias listadas no Novo Mercado da BM\&F-Bovespa este percentual de participação acionária que determina a obrigação de realizar oferta pública aos demais acionistas varia entre o mínimo de 5\% (cinco por cento) (caso, por exemplo, da Datasul S.A., da Klabin Segall S.A. e da Rodobens Negócios Imobiliários S.A.) e o máximo de 30\% (trinta por cento) (caso, por exemplo, da Natura Cosméticos S.A.). Até 12.12.2009, não há companhias listadas no Nível 2 e/ou no Nível 1 da BM\&F-Bovespa com este tipo de cláusulas de proteção à dispersão acionária (em $<$ www.cvm.com.br $>$. Acesso em 12.12.2009).
} 
de aquisição de ações (OPA) para aquisição da totalidade das ações de emissão da companhia; e (ii) comunicar ao Diretor de Relação com Investidores (DRI) da companhia e/ou ao diretor de pregão da bolsa de valores, que coordenará o referido leilão de compra de ações.

Em relação às cláusulas de proteção à dispersão acionária do “Tipo A”, as mesmas contemplam procedimento para fixação do preço de compra a ser ofertado pelas ações de emissão de tal companhia aberta objeto da OPA, prevendo-se, usualmente, que o preço não poderá ser inferior ao maior valor entre: (i) o valor econômico apurado por meio de laudos de avaliação, cuja forma de elaboração é estatutariamente prevista; (ii) o valor patrimonial constante do último balanço auditado da companhia; e (iii) a maior cotação unitária em bolsa das ações de emissão da companhia em determinado período anterior à realização da OPA.

O exame das cláusulas de proteção à dispersão acionária do “Tipo A”, que vêm sendo adotadas por inúmeras companhias abertas brasileiras, revela que, em muitos casos, a sistemática para a fixação do preço de compra a ser ofertado na oferta pública destinada aos demais acionistas da companhia cria situações proibitivas à aquisição de participação acionária em percentual que obrigue a realização da oferta pública ${ }^{296}$. Os valores a serem ofertados revelam-se tão elevados que a consumação de uma oferta pública subsequente seria irreal e não teria base econômica e/ou financeira que justificasse a sua realização ${ }^{297}$.

A finalidade dessa disposição estatutária é, de certa forma, proteger a companhia contra ofertas hostis, ao tornar demasiadamente oneroso o aumento de participação acionária para além de determinados limites estatutariamente previstos.

\footnotetext{
${ }^{296}$ Exemplificativamente, cite-se o caso da EMBRAER - Empresa Brasileira de Aeronáutica S.A., listada perante o Novo Mercado da BM\&F-Bovespa, cujo estatuto social estabelece que o preço de compra a ser ofertado deverá ser o maior valor entre (i) a cotação unitária mais alta atingida pelas ações de emissão de tal companhia durante o período de 12 meses anterior à OPA; (ii) o preço mais alto pago pelo acionista adquirente, durante o período de 36 meses anterior à OPA; (iii) o valor equivalente a 14,5 vezes o EBITDA de tal companhia deduzido do endividamento consolidado líquido; e (iv) o valor equivalente a 0,6 vezes o valor dos pedidos firmes em carteira de tal companhia, deduzido do endividamento consolidado líquido da Companhia. Em qualquer dos casos, o valor obtido deve ainda ser acrescido de um prêmio de $50 \%$.

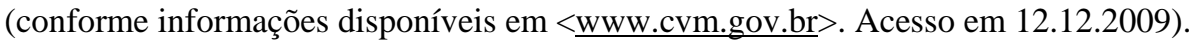

${ }^{297}$ Cabe aqui reiterar que, na experiência estrangeira, há recomendação de que as medidas defensivas não podem ser obstáculos intransponíveis.
} 
Entretanto, tais cláusulas de proteção à dispersão acionária vêm sendo adotadas inclusive por companhias abertas submetidas ao controle concentrado e sem perspectivas de serem submetidas a estruturas de dispersão acionária em seu capital ${ }^{298}$.

A experiência prática brasileira ainda não colocou à prova a efetiva necessidade de realização de OPA estatutária para adquirir a totalidade das ações de emissão da companhia, em decorrência de determinado acionista ter adquirido ações de emissão da companhia, em quantidade igual ou superior ao percentual estatutariamente previsto. As cláusulas de proteção à disperção acionária ainda não foram testadas em tal extensão.

Todavia, há no Brasil precedente importante no caso Mittal Steel Company N. V. ("Mittal”) e Arcelor S.A. (“Arcelor”), em que a Mittal (companhia aberta sediada na Holanda) adquiriu no exterior o controle da Arcelor (companhia aberta sediada em Luxemburgo), por meio de uma oferta pública voluntária.

A Arcelor possuía subsidiárias e valores mobiliários listados em diversas jurisdições, inclusive no Brasil, onde era controladora da Arcelor Brasil S.A. (“Arcelor Brasil”) e da Acesita S.A. (“Acesita”).

O estatuto social da Arcelor Brasil estabelecia que em caso de aquisição de poder de controle da companhia, por meio de aquisição de ações de emissão de seu controlador final, exigiria a realização de oferta pública de aquisição de ações no Brasil, sendo que a Acesita, também controlada pela Arcelor no Brasil, não possuía disposição estatutária neste sentido.

Em decorrência da aquisição do controle da Arcelor pela Mittal, a CVM impôs à Mittal a obrigatoriedade de lançar oferta pública para a aquisição de ações da Arcelor Brasil $^{299}$, em cumprimento à referida disposição estatutária. A autarquia, em sua fundamentação, referiu-se ao artigo $4^{\circ}$, inciso IV, alínea "b", da Lei nº 6.385/76, no

\footnotetext{
${ }^{298}$ Luiza Rangel de Moraes escreve que “no Brasil, as técnicas de defesa (poison pills) vão desde as medidas adotadas por companhias com acionista controlador definido, tendo por objetivo evitar a concentração de liquidez em um único acionista, até as que se destinam a prevenir uma tomada de controle hostil, em companhias com controle societário pulverizado” (MORAES, Luiza Rangel de. A Pulverização do Controle de Companhias Abertas. RDB. São Paulo: RT, n. 32, pp. 49-84, abr./jun. 2006, p. 77).

${ }^{299}$ CVM, Processo Administrativo RJ-2006-6209, Rel. Dir. Wladimir Castelo Branco Castro, j. 25.09.2006.
} 
pressuposto de estar "exercendo suas atribuições com a finalidade de proteger os titulares de valores mobiliários e os investidores de mercado contra atos ilegais de administradores e acionistas controladores”, fazendo referência, ainda, aos artigos $9^{\circ}$, inciso $\mathrm{V}$, e 11 , $\S 4^{\circ}$, da mesma lei ${ }^{300}$.

Há, portanto, posição consolidada na CVM de exigir o cumprimento de obrigação estatutária que determine a realização de oferta pública, tal como a sanção contida nas cláusulas de proteção à dispersão acionária do “Tipo A”.

Neste sentido, ainda que as cláusulas de proteção à dispersão acionária, em sua versão existente em inúmeras companhias abertas brasileiras, ainda não tenha sido submetida a teste concreto em discussões judiciais ou administrativas, perante a CVM, o caso Arcelor Brasil é precendente importante em que a CVM obrigou acionistas a cumprirem disposição estatutária determinando a realização de oferta pública.

As cláusulas de proteção à dispersão acionária servem, também, para evitar a formação de “minorias relevantes”, isto é, acionistas minoritários dotados de direitos especiais por possuirem participação acionária expressiva na companhia. A cláusula de proteção à dispersão acionária acaba evitando que acionistas minoritários detenham ações de emissão da companhia para além de determinados percentuais de participação acionária e, assim, assumam direitos decorrentes do acúmulo de ações a partir de tais percentuais.

Dentre as alternâncias existentes nas cláusulas de proteção à dispersão acionária presentes nos estatutos sociais de companhias abertas brasileiras, destaque-se positivamente aquelas que envolvem o Conselho de Administração na análise da oferta

\footnotetext{
${ }^{300}$ O Colegiado da CVM, no caso em exame, manteve a decisão da área técnica (i.e., SEP e SRE), que haviam consignado entendimento pela obrigatoriedade de realização de OPA estatutária pela Mittal, em favor dos acionistas da Arcelor Brasil, fundamentando-se em parecer da Procuradoria Federal Especializada (CVM, Memorando 1004/2006, Procuradoria Federal Especializada - PFE, 31.08.2006). O Diretor Relator Wladimir Castelo Branco Castro opinou que "não há dispositivo que indique ser a violação da lei diferente, ou menos grave, que a praticada contra o estatuto. Daí porque, para efeitos da Lei 6.385, quem descumpre o estatuto, comete uma ilegalidade. Contanto que o estatuto esteja livre de vícios de vontade e de validade, deve ser seguido como se segue à lei e punido como à lei se pune", referindo-se corretamente ao estatuto social como "ato-regra", seguindo a melhor lição da doutrina (COMPARATO; Fábio Konder. Da imprescripitibilidade da ação direta de nulidade de norma estatutária. In: de Direito Empresarial. Rio de Janeiro: Forense, 1981, pp. 221-222). Novos Ensaios e Pareceres
} 
pública realizada aos acionistas e preservam o direito destes decidirem quanto a proposta, porém, dotados do auxílio por parte da administração ${ }^{301}$.

Alguns dos estatutos sociais que contemplam a existência destas cláusulas de proteção à dispersão acionária não só preveem os “efeitos venenosos” referidos nos Tipos A e B tratados acima, como também estabelecem sanções em caso de descumprimento das determinações contidas em tais cláusulas.

São comuns os casos em que se prevê que, na hipótese de o acionista adquirente de ações em quantidade superior ao percentual previsto no estatuto social não realizar a oferta pública estatutariamente exigida, será convocada assembleia geral extraordinária para deliberar a suspensão do exercício de seus direitos, nos termos do artigo 120 da Lei $n^{0}$ 6.404/76. O acionista inadimplente não poderá votar em tais deliberações e poderá ser responsabilizado pelas perdas e danos causados aos demais acionistas em decorrência do descumprimento das obrigações estatutárias.

Há também restrições contidas em tais cláusulas estatutárias de controvertida proteção à dispersão acionária, no sentido de vedar a alteração e/ou a exclusão de tal cláusula do estatuto social da companhia aberta que a adote. Nestes casos, prevê-se que alterações estatutárias que limitem o direito dos acionistas à realização da oferta pública estabelecida no estatuto social obrigarão o acionista que tenha votado a favor da alteração ou exclusão de tal dispositivo a realizar a oferta pública exigida pelo estatuto social.

Observa-se, desta maneira, uma tentativa de tornar imutável a cláusula estatutária de proteção à dispersão acionária, com o estabelecimento de punição e encargo aos

\footnotetext{
${ }^{301}$ A este respeito, refira-se à bem estruturada cláusula de proteção à dispersão acionária contida no estatuto social da BM\&F-Bovespa S.A. - Bolsa de Valores, Mercadorias e Futuros, que prevê que, diante da publicação de edital de oferta pública para aquisição de ações de tal companhia, o Conselho de Administração deverá reunir-se a fim de apreciar os termos e condições da oferta formulada. O estatuto social estabelece princípios a serem observados pelo Conselho de Administração que, resumidamente, (i) poderá contratar assessoria externa especializada, com o objetivo de prestar assessoria na análise da conveniência e oportunidade da oferta, no interesse geral dos acionistas e do segmento econômico em que atuam as controladas da companhia; e (ii) deverá divulgar, justificadamente, aos acionistas, o seu entendimento acerca da conveniência e oportunidade da oferta pública. Caso o Conselho de Administração entenda que a aceitação da oferta pública formulada atende ao melhor interesse dos acionistas e do segmento econômico em que atuam as controladas da Companhia, este deverá convocar Assembleia Geral Extraordinária, destinada a deliberar sobre a revogação da limitação ao número de votos prevista em tal estatuto social, condicionando tal revogação a que, com o resultado da oferta, o adquirente do controle se torne titular de no mínimo 2/3 das ações de emissão da companhia, excluídas as ações em tesouraria.
} 
acionistas que votarem pela alteração ou exclusão de tal dispositivo, tornando-os obrigados a realizar oferta pública para adquirir a totalidade das ações de emissão da companhia. Esta disposição acessória nas cláusulas de proteção à dispersão acionária passaram a ser coloquialmente referidas, pela prática societária, sob o jargão de “cláusulas pétreas”302.

Esta disposição estatutária acessória destinada a tornar imutável a cláusula de proteção à dispersão acionária, indevidamente referida como “cláusula pétrea”, tem sido duramente criticada pela doutrina ${ }^{303}$ e tem suscitado intensas reflexões por parte da CVM, que, após a realização da Audiência Pública CVM n ${ }^{0} 03 / 09^{304}{ }^{305}$, editou o Parecer de Orientação nº 36/2009, que tem causado grande polêmica acerca de seu conteúdo.

${ }^{302}$ As cláusula pétreas consistem em limitações materiais ao poder de reforma da Constituição Federal. Nelas, são inscritas as matérias que ficam fora do alcance do consitituinte derivado. No sistema constitucional brasileiro, as cláusulas pétras estão previstas no artigo 60, §4º da Consitutição Federal e abrangem (i) a forma federativa de Estado; (ii) o voto direto, secreto, universal e periódico; (iii) a separação dos poderes; e (iv) os direitos e garantias individuais.

${ }^{303}$ Modesto Carvalhosa pondera que "a poison pill pretende adquirir, em muitos casos, feições de imutabilidade, de verdadeira cláusula 'pétrea' [...]. São exemplos deste tipo aberrante as cláusulas estatutárias que punem aqueles acionistas que votarem em assembléia geral pela alteração ou exclusão, obrigando-os a realizar a OPA referente a todas as ações de emissão da companhia, sendo esta a própria oferta prevista na cláusula da poison pill. Percebe-se, neste caso, a extrema ilegalidade e imoralidade deste tipo de cláusula de poison pill, pois constrange o exercício do direito de voto do acionista, o qual deverá ser manifestado, sempre, de forma livre e em consonância com o interesse social” (CARVALHOSA, Modesto. As Poison Pills Estatutárias na Prática Brasileira: alguns aspectos de sua Legalidade. In: CASTRO, Rodrigo R. Monteiro; ARAGÃO, Leandro Santos de. Direito Societário: Desafios Atuais. São Paulo: Quartier Latin, pp. 19-29, 2009, p. 26).

${ }^{304}$ Através da Reunião do Colegiado da CVM realizada em 14/04/2009, os membros do Colegiado da CVM decidiram submeter tal Audiência Pública no 03/2009, acompanhada de uma minuta do Parecer de Orientação, que trataria da matéria. As discussões no âmbito do Eg. Colegiado da CVM originaram-se de Memorando dos Diretores Marcos Barbosa Pinto e Otávio Yazbek, datado de 14.04.2009, submetido à apreciação dos demais membros do Colegiado da CVM. Curiosamente, tal Memorando propunha-se a “analisar o impacto desse Parecer [de Orientação no 36/2009] do ponto de vista econômico, sem abordar questões jurídicas, que devem ser avaliadas em momento oportuno”. Com a devida vênia aos respeitáveis Diretores da CVM, não entendemos haver momento mais oportuno para reflexão jurídica sobre a matéria do que o contexto de uma discussão em Audiência Pública.

${ }^{305}$ Após as contribuições havidas durante o período estabelecido no Edital de Audiência Pública n ${ }^{\circ}$ 03/2009, a CVM divulgou o Relatório de Análise das contribuições realizadas. Parece-nos que uma das questões mais relevantes sobre o tema escapou à apreciação da autarquia, que, embora tenha chancelado estatutos sociais de inúmeras companhias abertas que realizaram ofertas públicas com o crivo da CVM, contendo tais disposições estatutárias acessórias em seus estatutos sociais, agora se posiciona pela incompatibilidade de tais dispositivos estatutários com regras da Lei $n^{0}$ 6.404/76. Como medida de coerência, algumas contribuições haviam sugerido que (i) a CVM não concedesse registro de companhia aberta às companhias cujos estatutos sociais contivessem as ditas “cláusulas pétreas”; e (ii) a CVM não registrasse novas distribuições públicas de ações de companhias abertas que contivessem tais disposições estatutárias acessórias, enquanto as mesmas não fossem removidas dos estatutos sociais. Entretanto, a CVM, desperdiçando a ocasião para enfrentar integralmente a matéria, “considerou desnecessário e inoportuno definir a priori efeitos do parecer de orientação sobre o procedimento de registro de companhia aberta”. Fica, desta forma, o mercado em geral sem saber o rumo que norteará a postura da CVM diante de tais situações, que simplesmente decidiu não 
A CVM consignou entendimento de que "a aplicação concreta dessas disposições não se compatibiliza com diversos princípios e normas da legislação societária em vigor, em especial os previstos nos arts. 115, 121, 122, I, e 129” da Lei n ${ }^{\circ} 6.404 / 76$. A autarquia, complementando suas conclusões, posicionou-se no sentido de que "a CVM não aplicará penalidades, em processos administrativos sancionadores, aos acionistas que, nos termos da legislação em vigor, votarem pela supressão ou alteração da cláusula de proteção à dispersão acionária, ainda que não realizem a oferta pública prevista na disposição acessória” $^{306}$.

Embora reconheçamos a importância do posicionamento da CVM sobre a matéria e, quiçá, a própria regulação da utilização de medidas defensivas no Brasil, conforme será exposto em nossas conclusões, entendemos que a CVM enfrentou de forma tímida a questão, abordando apenas lateralmente a matéria.

Em relação aos dispositivos legais apontados pela CVM como inconsistentes com as cláusulas de proteção à dispersão acionária (i.e., artigos 115, 121, 122, I, e 129 da Lei $n^{\circ}$ 6.404/76), entendemos ser necessário estabelecer algumas considerações.

No que tange ao artigo 115 da Lei $\mathrm{n}^{\circ}$ 6.404/76, entende a CVM que "as disposições acessórias podem conduzir à violação” de tal dispositivo, uma vez que “o ônus econômico por elas estabelecido pode, na prática, impedir o acionista de exercer seu direito de voto no interesse da companhia”. Concordamos que tal disposição estatutária acessória

condicionar o registro de ofertas públicas à supressão das "cláusulas pétreas", em observância ao art. 2º parágrafo único, XIII, da Lei nº 9.784/99.

${ }^{306}$ Em Portugal, há a figura da OPA estatutária como mecanismo de defesa contra tomadas de controle, que em muito se assemelha com as nossas cláusulas de proteção à dispersão acionária. Esclareça-se, entretanto, que não há noticias da adoção em Portugal de disposições estatutárias destinadas a assegurar a imutabilidade da OPA Estatutária. O doutrinador português António Menezes Cordeiro, examinando o papel da CMVM diante de eventual descumprimento da OPA Estatutária, pondera que "do ponto de vista da administração mobiliária, a OPA estatutária é uma OPA facultativa, isto é: uma OPA que não é imposta por lei. Assim, a CMVM irá tratar o oferente como um interessado numa OPA geral não obrigatória. O facto de ele agir nos termos dum contrato-promessa, dum mandato, dum contrato a favor de terceiro ou dos estatutos duma sociedade é, salvo preceito expresso em contrário, res inter alios acta. Tal ocorrência não provoca a aplicação de quaisquer regras legais diferentes das convocadas por uma OPA facultativa: tão-pouco afasta alguma ou algumas delas. A inobservância das regras estatutárias que imponham OPAs gerais não tem relevância mobiliária. As sanções que daí advenham são do foro interior da sociedade: inibições de voto ou cláusulas penais. A lei permite, em geral, umas e outras, nada vedando a sua associação à inobservância de determinado processo aquisitivo. Quaisquer dúvidas ou litígios subsequentes deverão ser dirimidos perante os tribunais comuns” (CORDEIRO, António Manuel da Rocha e Menezes. A OPA Estatutária como Defesa contra Tomadas Hostis. ROA, Lisboa, n. 58, pp. 133-145, 1998. pp. 141-142). 
pode revelar-se incompatível com o artigo 115 da Lei $n^{\circ} 6.404 / 76^{307}$, mas entendemos que as conclusões a este respeito não se limitam àquelas apresentadas pela CVM.

Na sistemática da Lei $n^{0}$ 6.404/76, o direito de voto é o principal direito político atribuído ao acionista, o qual, desde que exercido em atendimento ao interesse social e respeitando a legislação societária, pode ser utilizado sem nenhum constrangimento e/ou restrição.

O estabelecimento, no estatuto social, de sanções de ordem econômica, que acabem por impor indicações de exercício do direito de voto pelos acionistas é incompatível com todo o sistema de voto da legislação acionária, podendo, inclusive, ser entendido como usurpação do direito de voto do acionista. Esclareça-se que: (i) embora o acionista conserve o direito de voto, o acionista não possui a faculdade de escolher a forma de exercê-lo; e (ii) a restrição ao exercício do direito de voto pelo acionista não é consistente em nenhuma relação contratual em que tal acionista tenha pactuado a forma

\footnotetext{
${ }^{307}$ Ainda em relação ao artigo 115 da Lei $n^{\circ}$ 6.404/76, registre-se o questionável entendimento expresso no Memorando da lavra dos Diretores da CVM Marcos Barbosa Pinto e Otávio Yazbek, no sentido de que "[...] o acionista que pretenda suprimir a poison pill para adquirir o controle enfrentará sérios óbices jurídicos. Tendo em vista o disposto no art. 115 da Lei $n^{\circ}$ 6.404, de 1976, é muito provável que o acionista esteja impedido de votar na deliberação em questão, pois ela o beneficia de modo particular”. E, prosseguem, sustentando que “[a]inda que assim não fosse, a supressão da poison pill seguida da aquisição do controle seria suficiente para caracterizar o exercício do direito de voto em conflito de interesses ou abuso no exercício desse direito [...]” (CVM, Memorando, Dir. Marcos Barbosa Pinto e Dir. Otávio Yazbek, 14.04.2008. Disponível em: <http://www.cvm.gov.br/port/infos/6491-0.asp>. Acesso em: 12.12.2009. Primeiro, referimo-nos ao nosso entendimento já registrado de que deliberações em matérias de benefício particular não ensejam a proibição de voto (ex ante) pela sistemática prevista no artigo 115 da Lei $\mathrm{n}^{\circ}$ 6.404/76, mas devem ser submetidas à sistemática de controle substancial do exercício do direito de voto (ex post). Neste ponto, referir-se ao nosso artigo sobre o tema (NASCIMENTO, João Pedro Barroso do. Conflito de interesses no exercício do direito de voto nas sociedades anônimas ( $2^{\mathrm{a}}$ parte). RDB. São Paulo: RT, n. 25, jul./set. 2004, pp. 82-103, especialmente nas pp 94-97). Segundo, registramos aqui que, em nosso entendimento, a simples supressão da poison pill (sic) seguida da aquisição do controle não é elemento determinante para voto exercido em conflito de interesses ou em abuso de direito, nos termos do artigo 115 da Lei $n^{\circ}$ 6.404/76. O conflito de interesses só existirá se houver colidência inconciliável entre o interesse particular dos acionistas que houverem aprovado a supressão da poison pill (sic) e o interesse social. O abuso de direito de voto ocorre quando o voto é exercido: (i) a fim de causar dano à companhia ou a outros acionistas; ou (ii) de obter, para si ou para outrem, vantagem a que não faz jus e de que resulte, ou possa resultar, prejuízo para a companhia ou para outros acionistas. Não se pode disciplinar em abstrato a existência de abuso do direito de voto meramente quando determinado acionistas valer-se de tal direito para suprimir disposição estatutária e, em seguida, tomar o controle da companhia. O abuso do direito de voto não deve ser apontado em abstrado e pressupõe o exame da situação fática em que se insere. Neste sentido, pergunta-se, a finalidade da supressão da disposição estatutária seria causar dano à companhia ou a outros acionistas? E ainda, o exercício do direito de voto em tal caso estaria orientado a obter, para si ou para outrem, vantagem a que não faz jus e de que resulte, ou possa resultar prejuízo para a companhia ou para outros acionistas? Na melhor lição de José Luiz Bulhões Pedreira e Alfredo Lamy Filho, estes são os padrões genéricos do abuso no exercício do direito de voto (LAMY FILHO, Alfredo; BULHÕES, José Luiz Bulhões. Direito das Companhias. v. 1, Rio de Janeiro: Forense, 2009, p. 405).
} 
como se dará o exercício do direito de voto, mas sim uma consequência do fato de ser acionista de companhia que contempla disposição estatutária neste sentido ${ }^{308}$.

Passando ao artigo 121 da Lei n 6.404/76, entende a CVM que “ao impor um ônus significativo aos acionistas que aprovarem a supressão da cláusula de proteção à dispersão acionária, as disposições acessórias podem limitar a soberania da assembléia geral”, contrariamente ao artigo 121 da Lei $n^{\circ}$ 6.404/76. Na mesma linha, é o entendimento da CVM, em relação ao artigo 122, inciso I, da Lei $n^{\circ}$ 6.404/76, no sentido de que a imutabilidade decorrente da disposição estatutária acessória restringe a competência privativa da assembleia geral de reformar o estatuto social, tal como estabelecido no inciso I do artigo 122 da Lei $\mathrm{n}^{0}$ 6.404/76.

A respeito dos artigos 121 e 122, inciso I, da Lei $\mathrm{n}^{0}$ 6.404/76 concordamos parcialmente com as conclusões da CVM. De fato, a existência de sanção estatutária que imponha ônus pecuniário ao acionista que votar favoravelmente à alteração e/ou exclusão da cláusula de proteção à dispersão acionária representa uma inadequada limitação ao voto atribuído ao acionista. A soberania da assembleia geral não é limitada por tal disposição, permanecendo a assembleia geral como órgão supremo da companhia. O que é limitado por tal disposição são os direitos políticos atribuídos aos acionistas, notadamente o direito de voto, com o reconhecimento permanente de que a imutabilidade da regra estatutária é a vontade social, com a consequente redução da importância do voto exercido pelo acionista.

Da mesma forma, a competência para reformar o estatuto social da companhia não é retirada da assembleia geral, não havendo, em nosso entendimento, incompatibilidade absoluta com o artigo 122, inciso I, da Lei $n^{\circ}$ 6.404/76. O que há é, mais uma vez, uma inadequada redução da importância do direito de voto e, consequentemente, da assembleia geral. Tal órgão social não funcionará propriamente como o centro em que é definida a vontade social sobre a exclusão e/ou alteração de tais cláusulas de proteção à dispersão acionária, uma vez que a definição já estará estampada no estatuto social e com caráter de perpetuidade, sob pena de submeter os acionistas interessados em excluir e/ou alterar tal disposição estatutária a elevado encargo pecuniário.

\footnotetext{
${ }^{308}$ Para reforçar o argumento, imagine a possibilidade de o acionista sequer ter votado favoravelmente à deliberação assemblear para inserção de tal regra no estatuto social da companhia, especialmente no caso de acionistas anteriores à existência de tal disposição.
} 
Por último, no que se refere ao artigo $129, \S 1^{\circ}$, da Lei $n^{0} 6.404 / 76$, a CVM registra entendimento de que “o efeito prático das disposições acessórias é exigir unanimidade, ou quase unanimidade, para que a cláusula de proteção à dispersão acionária possa ser suprimida. Indiretamente, as disposições acessórias podem aumentar o quorum previsto em lei para essa deliberação social” o que é vedado pelo artigo 129 , §1 ${ }^{\circ}$, da Lei $\mathrm{n}^{\circ}$ $6.404 / 76$.

Endossamos o entendimento da CVM em tal aspecto. Embora a disposição não importe na majoração do quorum legal para reforma do estatuto social, há a consequência prática decorrente de tal regra de exigir-se a oferta pública aos demais acionistas da companhia. A sanção inerente à cláusula de proteção à dispersão acionária só não será aplicável no caso de deliberação tomada por unanimidade, hipótese em que não haverá destinatário para a oferta pública.

Além dos dispositivos legais apontados pela CVM como inconsistentes com as disposições de imutabilidade das cláusulas de proteção à dispersão acionária, destaca-se interessante contribuição realizada na Audiência Pública nº 03/09 no que se refere ao artigo 106 da Lei $n^{\circ} 6.404 / 76^{309}$.

De acordo com esta contribuição, as ditas “cláusulas pétreas” ferem o artigo 106 da Lei ${ }^{0}$ 6.404/76, na medida em que impõem ônus patrimonial, pela realização de oferta pública, ao acionista que já integralizou o capital social por ele subscrito, na hipótese de tal acionista pretender alterar e/ou excluir a cláusula de proteção à dispersão acionária.

Parece-nos consistente tal entendimento, na medida em que não pode existir qualquer ônus patrimonial, de caráter punitivo, aos acionistas que exercerem seu direito de voto no sentido de alterar e/ou excluir a cláusula de proteção à dispersão acionária do estatuto social da companhia aberta, sob pena de se impor estatutariamente ao acionista consequência patrimonial além daquela a qual se obrigou ao subscrever suas ações.

Para além do exame deste aspecto imutável das cláusulas de proteção à dispersão acionária, analisando-as de forma integral e não apenas em sua feição inalterável,

\footnotetext{
${ }^{309}$ Conforme Relatório de Análise da Audiência Pública nº 03/09, expedido pela CVM, “Carvalhosa e Eizirik propõem incluir o art. 106 da Lei 6.404, de 1976, na fundamentação da Minuta”.
} 
reflete-se se as cláusulas de proteção à dispersão acionária não representam violação ao artigo 36 da Lei $n^{\circ}$ 6.404/76, uma vez que representam limitação à circulação de ações emitidas por companhias abertas.

Nesta sequência de ideias, pondere-se que o conteúdo das cláusulas de proteção à dispersão acionária obriga a realização de oferta pública aos demais acionistas da companhia, em caso de aquisição de ações por indivíduo para além de determinados patamares de participação acionária. Desta maneira, poder-se-ia interpretar que tal disposição estatutária é capaz de restringir a circulação da ação de companhia aberta quando o potencial interessado na aquisição das ações já detém ações em quantidade próxima ao limite estatutariamente estabelecido.

Esta análise do artigo 36 da Lei $\mathrm{n}^{\circ}$ 6.404/76, adicional àquelas sobre a imutabilidade da cláusula estatutária, não é hierarquicamente o principal ponto combalido pelas controvertidas cláusulas de proteção à dispersão acionária, mas é também uma linha de equilíbrio à qual se deve atentar no exame da validade de tal defesa.

\subsection{LIMITAÇão AO NÚMERO DE VOTOS}

A cada ação ordinária corresponde um voto nas deliberações da Assembleia Geral, conforme estabelece o caput do artigo 110 da Lei $n^{\circ}$ 6.404/76. Da mesma forma, a cada ação preferencial corresponde um voto nas deliberações da assembleia geral, embora o artigo 111 da Lei ${ }^{\circ}$ 6.404/76 estabeleça que o estatuto social poderá deixar de conferir às ações preferenciais algum ou alguns dos direitos reconhecidos às ações ordinárias, inclusive o direito de voto, ou conferi-lo com restrições. 
A limitação ao número de votos consiste em previsão estatutária, nos termos do artigo $110, \S 1^{\circ}$, da Lei $n^{\circ} 6.404 / 76$, destinada a estabelecer número máximo de votos a ser exercido por cada acionista ${ }^{310}$.

José Luiz Bulhões Pedreira, com a coerência que lhe é característica, doutrina que:

[...] a lei brasileira não especifica o tipo de limite de votos que pode ser usado pelo estatuto e as modalidades referidas na doutrina são: (a) número absoluto de votos que podem ser manifestados por cada acionista; (b) número de ações determinado pelo respectivo valor nominal, ou por determinada porcentagem do valor do capital social; (c) porcentagem do número total de ações votantes da companhia ou das ações votantes cujos titulares estejam presentes ou representados na assembléia; (d) relação decrescente com o número de ações de que o acionista é titular ${ }^{311}$.

Trata-se de medida defensiva simples e eficaz, capaz de limitar a um número máximo a quantidade de votos a ser exercido por um acionista ou grupo de acionistas. Exemplificativamente, se o estatuto social estabelecer que, independentemente do número de ações votantes detida por cada acionista, o número de votos a ser exercido por ele corresponderá a, no máximo, $10 \%$ do capital votante, dificilmente algum acionista se predisporá a adquirir quantidade de ações superior a este percentual, uma vez que não poderá exercer o direito de voto em relação às ações que sobejarem tal limite.

António Menezes Cordeiro pondera que se, por exemplo, o estatuto social de determinada companhia aberta estabelecer a limitação do número de votos que um acionista e/ou grupo de acionistas possam exercer em assembleia geral em 10\% do capital votante, "um takeover exigirá a compra de mais de 90\% das acções com direito a voto: só assim o adquirente, com os seus (bloqueados) 10\% dos votos deterá a maioria”312.

\footnotetext{
${ }^{310} \mathrm{O}$ artigo $110, \S 1^{\circ}$, da Lei $\mathrm{n}^{\circ} 6.404 / 76$ reproduz, sem qualquer alteração, a redação que constava da parte final do artigo 80 do Decreto-Lei n ${ }^{\circ}$ 2627/40, nos seguintes termos: "A cada ação comum ou ordinária corresponde um voto nas deliberações da assembléia geral, podendo os estatutos, entretanto, estabelecer limitações ao número de votos de cada acionista”.

${ }^{311}$ BULHÕES PEDREIRA, José Luiz. Limite Estatutário do Direito de Voto. In: LAMY FILHO, Alfredo; BULHÕES PEDEIRA, José Luiz. A Lei das S.A. v. 2, 2. ed. Rio de Janeiro: Renovar, 1996, p. 75.

${ }^{312}$ CORDEIRO, António Manuel da Rocha e Menezes. A OPA Estatutária como Defesa contra Tomadas Hostis. ROA, Lisboa, n. 58, 1998, pp. 133-145.
} 
Observa-se, deste modo, que a limitação ao número de votos (i) funciona não apenas restrigindo o interesse do acionista em adquirir participação acionária para além de determinados parâmetros percentuais estabelecidos no estatuto social, já que não poderá usufruir proporcionalmente os direitos de voto inerentes às ações a partir do limite estatutariamente estabelecido $^{313}$; mas também (ii) representa mecanismo capaz de forçar o acionista a adquirir participação acionária expressiva para que, mesmo diante da limitação ao número de votos, possa deter a maioria dos votos a serem manifestados em assembleias da companhia.

Em relação à adequação da medida defensiva ao regime jurídico pátrio, em linha com a opinião expressada por José Luiz Bulhões Pedreira ${ }^{314}$, é possível entender que tal proteção estatutária é compatível com a legislação brasileira, devendo o estatuto social regular, em cada caso concreto, as características específicas nas quais se dará a limitação ao número de votos a ser exercido por cada acionista.

As medidas defensivas das deliberações sujeitas a quorum de "super-maioria" qualificada são uma das pioneiras espécies adotadas como proteção contra tomadas de controle em companhias com dispersão acionária.

Tal espécie de medida defensiva consiste em disposição estatutária estabelecendo elevado quorum qualificado para a deliberação de determinadas matérias a serem submetidas à aprovação da Assembleia Geral, de maneira que o potencial adquirente

\footnotetext{
${ }^{313}$ Segundo Alexandre Soveral Martins, a limitação do número de votos, por meio de disposição estatutária, que em Portugal está prevista no artigo 384/2 do Código das Sociedades Comerciais, desincentiva o lançamento de oferta pública visando à tomada de controle (MARTINS, Alexandre Soveral. Valores Mobiliários (Acções). Coimbra: Almedina, 2003, p. 64).

${ }^{314}$ A opinião de Bulhões Pedreira é a de que "é compatível com a lei brasileira em vigor o dispositivo estatutário que estabelece limite para os votos emitidos por cada acionista - em nome próprio e como representante de outro ou outros - mas se o estatuto social não é expresso, o limite aplica-se aos votos de cada acionista, considerado separadamente, sejam os votos exercidos pelo próprio acionista ou por mandatário” (BULHÕES PEDREIRA, José Luiz. Limite Estatutário do Direito de Voto. In: LAMY FILHO, Alfredo; BULHÕES PEDEIRA, José Luiz. A Lei das S.A. v. 2, 2. ed. Rio de Janeiro: Renovar, 1996, p. 77).
} 
do controle da companhia-alvo esteja obrigado a adquirir não apenas quantidade de ações que lhe assegure a maioria do capital votante da companhia-alvo, mas sim participação acionária em quantidade ainda mais expressiva, capaz de aprovar matérias relevantes, que tenham exigência estatutária de um quorum de deliberação qualificado para serem aprovadas.

Esta espécie de medida defensiva foi utilizada com frequência nos EUA como medida capaz de evitar o "two-tier takeover", sobre o qual falamos no item 4.2, no qual se realizava a clássica operação de tomada de controle, que conjugava uma oferta pública de aquisição de ações representativas do controle da companhia-alvo seguida de (i) oferta pública de aquisição de ações por valor significativamente menor do que aquele oferecido na oferta pública por meio da qual se adquiriu o controle; ou (ii) operação de incorporação da companhia-alvo em outra companhia.

Com o quorum de deliberação qualificado, exigia-se elevado percentual de participação no capital votante para a aprovação de eventual incorporação da companhiaalvo em outra, tornando difícil o segundo passo da tomada de controle realizada sob a técnica coercitiva do "two-tier takeover" 315.

De maneira geral, o objetivo das medidas defensivas das “deliberações sujeitas a quorum de 'super-maioria' qualificada” é estabelecer elevados percentuais de participação no capital votante para aprovação de determinadas matérias a serem submetidas à deliberação em assembleia geral. Desta forma, pretende-se elevar a quantidade de ações que o potencial interessado no controle deverá adquirir para assumir o poder de controle em relação à companhia-alvo.

O estatuto social, ao estabelecer as matérias sujeitas ao quorum de deliberação qualificado, também subordinaria ao elevado quorum de deliberação a eventual reforma estatutária destinada a excluir e/ou alterar as matérias de quorum qualificado.

\footnotetext{
315 "Early efforts to erect barriers to hostile offers took the form of charter amendments that were adopted before an offer was made. One form imposed a supermajority vote requirement for approval of a "secondstep" merger eliminating the remaining shareholders with the objective, in part, of giving the bidder access to the target assets" (CHOPER, Jesse H.; COFFEE Jr., John C.; e GILSON, Ronald J. Cases and materials on corporations. 7. ed. Nova York: Aspen Publishers, 2008, p. 950).
} 
No Brasil, tal medida defensiva seria inaplicável às companhias abertas, em decorrência do disposto no artigo 129, $\S 1^{\circ}$, da Lei ${ }^{0}$ 6.404/76, que estabelece que apenas os estatutos sociais de companhias fechadas podem aumentar o quorum exigido para certas deliberações ${ }^{316}$.

Em consonância com o $\S 1^{\circ}$ do artigo 129 da Lei $n^{\circ}$ 6.404/76, o caput do artigo 136 da Lei $n^{\circ}$ 6.404/76 também prevê que apenas o estatuto de companhia, cujas ações não estejam admitidas à negociação em bolsa ou no mercado de balcão ${ }^{317}$, pode exigir quorum mais elevado do que o qualificado, estabelecido no artigo 136 da Lei n ${ }^{\circ}$ 6.404/76.

\section{CONSELHO DE AdMinistraçÃo ESCALONAdo (STAGGERED BoARD)}

A medida defensiva do conselho de administração escalonado, usualmente conhecida por sua expressão em inglês “staggered board”, consiste em dividir o conselho de administração em grupos ou classes, com períodos de mandatos distintos. Na experiência dos EUA, onde tais medidas defensivas têm a sua legalidade reconhecida e são

\footnotetext{
${ }^{316}$ Convém, neste ponto, destacar curiosidade histórica importante sobre o processo de elaboração do artigo $129, \S 1^{\circ}$, da Lei $\mathrm{n}^{\circ} 6.404 / 76$, em meio ao anteprojeto de autoria de José Luiz Bulhões Pedreira e Alfredo Lamy Filho, que revela elemento característico sobre a admissibilidade de previsão de quorum qualificado e, até mesmo, de unanimidade em companhias fechadas. Fábio Konder Comparato ensina que o primeiro anteprojeto de lei, de autoria de Bulhões Pedreira e Lamy Filho, submetido a exame de juristas em janeiro de 1975, apresentava a mesma regra do art. $129, \S 1^{\circ}$, do texto atual, mas com o acréscimo: "[...] desde que especifique as matérias e não exija a unanimidade.' Essa parte final desapareceu, já no anteprojeto entregue ao Ministério da Fazenda. Tal fato reforça a tese de que, pela simples análise do texto atual, não se pode dizer que esteja proibida a estipulação de unanimidade nas deliberações da assembléia geral [em companhias fechadas]" (COMPARATO, Fábio Konder. Novos Ensaios e Pareceres de Direito Empresarial. Rio de Janeiro: Forense, 1981, pp. 123-127).

${ }^{317}$ A atual redação constante do artigo 136 da Lei no 6.404/76 é decorrente da alteração promovida pela Lei $n^{\circ}$ 9457/97, sendo que, em sua versão original, ao invés de referir-se ao "estatuto da companhia cujas ações não estejam admitidas à negociação em bolsa ou no mercado de balcão" o dispositivo referia-se ao "estatuto da companhia fechada”. Há na doutrina opiniões de que a mudança realizada pela Lei nº 9457/97 autoriza a elevação do quorum de deliberação por companhias abertas, que possuam outros valores mobiliários, diversos das ações, admitidos à negociação em bolsa ou no mercado de balcão. Neste sentido, exemplificativamente: TEPEDINO, Ricardo. Assembléia Geral. In: LAMY FILHO, Alfredo; BULHÕES, José Luiz Bulhões. Direito das Companhias. v. 1, Rio de Janeiro: Forense, 2009, p. 1024. Com a devida vênia ao eminente advogado, este não nos parece o entendimento mais acertado em relação à matéria, tendo em vista o disposto no $\S 1^{\circ}$ do artigo 129 da Lei no $6.404 / 76$ e a distinção feita pelo caput do artigo $4^{\circ}$ da Lei $n^{\circ} 6.404 / 76$.
} 
amplamente utilizadas, são frequentes a existência de 3 (três) ou 4 (quatro) ${ }^{318}$ classes em que se dividem os membros do conselho de administração da companhia suscetível à tomada de controle.

O estatuto social da companhia que adote esta espécie de medida defensiva estabelecerá mandatos específicos para cada uma das classes de membros do conselho de administração, de modo que o vencimento dos respectivos mandatos se dê em períodos diferentes e cada classe de membros do conselho de administração tenha o prazo de seu mandato vencendo em um determinado ano.

Diante de tal medida defensiva, que somente poderá ser adotada por disposição do estatuto social, eventual adquirente de ações da companhia-alvo em quantidade suficiente para assumir seu controle não poderá substituir, de forma imediata, todos os membros da administração, porque seus mandatos não serão unificados. Desta forma, serão necessários dois ou três anos para que o novo controlador obtenha a maioria dos membros do conselho de administração ${ }^{319}$.

Nos EUA, o padrão legal é que todos os membros do conselho de administração sejam eleitos para mandatos de 1 (um) ano, mas permite-se que os estatutos sociais prevejam prazos mais longos e escalonados, criando o staggered board ${ }^{320}$. Esclareça-se que, de acordo com a legislação do Estado de Delaware ${ }^{321}$, adotada pela maioria das principais companhias abertas norte-americanas, os membros do conselho de administração integrantes de um staggered board somente podem ser destituídos com justa

\footnotetext{
${ }^{318}$ Os autores norte-americanos Jesse Choper, John Coffee Jr. e Ronald Gilson ensinam que, nos EUA, alguns estados permitem que o Conselho de Administração seja dividido em quatro classes, o que torna necessária a realização de três assembleias anuais para que a mudança de controle seja completamente refletida em tal órgão (por exemplo, conforme N.Y. Bus. Corp. Law §704(a) - 1986). Entretanto, a NYSE não lista companhias com Conselhos de Administração divididos em mais do que três classes (conforme, NYSE Listed Company Manual §304.00 - 2006) (CHOPER, Jesse H.; COFFEE Jr., John C.; e GILSON, Ronald J. Cases and materials on corporations. 7. ed. Nova York: Aspen Publishers, 2008, p. 950).

${ }^{319}$ CLARK, Robert Charles. Corporate Law. Boston / Toronto: Little, Brown and Company, 1986, p. 576.

320 ALLEN, William T.; KRAAKMAN, Reinier. Commentaries and Cases on the Law of Business Organization. Nova York: Aspen Publishers, 2003, p. 101.

${ }^{321}$ Conforme, Delaware General Corporation Law \$141. (k).
} 
causa, salvo se os documentos constitutivos da sociedade contenham disposição em sentido contrário $^{322}$.

Há evidências empíricas, na experiência norte-americana, de que a medida defensiva do conselho de administração escalonado (staggered board) aumenta as possibilidades para a companhia-alvo defender-se de uma tentativa de tomada de controle $^{323}$. Segundo William Allen e Reinier Kraakman ${ }^{324}$, investidores institucionais são usualmente contrários à adoção desta técnica de defesa contra tomada de controle, por entenderem que as mesmas têm reconhecido efeito de redução do valor de cotação das ações da companhia-alvo em bolsa de valores.

A medida defensiva do conselho de administração escalonado (staggered board) é inaplicável ao Brasil. Os artigos 122, inciso II, e 140, caput, da Lei ${ }^{\circ}$ 6.404/76 preveem que os membros do conselho de administração são destituíveis ad nutum e a qualquer tempo. Além disso, em nosso regime jurídico, os membros do conselho de

322 Jesse Choper, John Coffee Jr. e Ronald Gilson, em referência ao Delaware General Corporation Law §141 (k), ensinam que, exceto se o certificate of incorporation autorizar a destituição imotivada dos membros do conselho de administração, os mesmos somente poderão ser destituídos motivadamente. (CHOPER, Jesse H.; COFFEE Jr., John C.; e GILSON, Ronald J. Cases and materials on corporations. 7. ed. Nova York: Aspen Publishers, 2008, p. 950).

${ }^{323}$ A este respeito, refira-se a BEBCHUK, Lucian A.; COATES IV, John C.; SUBRAMANIAN, Guhan. The Powerful Antitakeover Force of Staggered Boards: Theory, Evidence and Policy. NBER Working Paper, $\mathrm{n}$. W8974, maio 2002. Disponível em: <http://ssrn.com/abstract=314645>. Acesso em 12.12.2009. Neste estudo, os Professores da Harvard Law School sustentam que os conselhos de administração escalonados (staggered boards) associados a planos de poison pill funcionam como defesa que duplica as chances da companhia-alvo resistir à tentativa de tomada de seu controle. Em resposta às conclusões de tal estudo, Stephen Bainbridge publicou o ensaio assim referido: BAINBRIDGE, Stephen M. Director Primacy in Corporate Takeovers: Preliminary Reflections. Stanford Law Review, n. 54, nov. 2002. Disponível em SSRN:

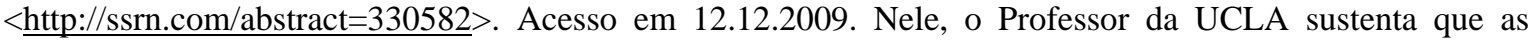
recomendações de Bebchuk, Coates e Subramanian adotam como premissa o princípio do shareholder primacy. Em seu entender, as conclusões seriam distintas se a abordagem fosse feita de acordo com o princípio do directors primacy. Em prosseguimento das reflexões acadêmicas, Bebchuk, Coates e Subramanian divulgaram outro ensaio reforçando suas constatações iniciais e posicionando-se contra a ideia de que a abordagem pelos directors primacy conduziria a conclusões diferentes daquelas de seus estudos originais (cf. BEBCHUK, Lucian A.; COATES IV, John C.; SUBRAMANIAN, Guhan, The Powerful Antitakeover Force of Staggered Boards: Further Findings and a Reply to Symposium Participants. Stanford Law Review, v. 55, pp. 885-917, 2002; Harvard Law and Economics Discussion Paper, n. 393. Disponível em SSRN: $<$ http://ssrn.com/abstract=360840 $>$. Acesso em 12.12.2009).

${ }^{324}$ ALLEN, William T.; KRAAKMAN, Reinier. Commentaries and Cases on the Law of Business Organization. Nova York: Aspen Publishers, 2003, p. 101. 
administração têm os seus mandatos unificados ${ }^{325}$, com prazos de gestão limitados a 3 (três) anos, nos termos do artigo 140, inciso III, da Lei n ${ }^{\circ}$ 6.404/76.

\subsection{CAVALEIRO BRANCO (WHITE KNIGHT)}

O cavaleiro branco ${ }^{326}$, usualmente referido por sua tradução em inglês white $k_{n i g h t^{327}}$, é a medida defensiva adotada pela companhia-alvo, por meio da qual são convidados terceiros, amigáveis à administração e/ou a determinados grupos de acionistas relevantes da companhia-alvo, para realizarem oferta para a aquisição do controle da companhia-alvo impedindo que o adquirente hostil o faça ${ }^{328}$.

Trata-se de medida defensiva utilizada no curso de oferta pública hostil de aquisição de controle, na qual se busca a substituição do adquirente hostil por outro

\footnotetext{
${ }^{325}$ Esclareça-se ainda que as companhias abertas que tenham aderido aos segmentos especiais Novo Mercado ou Nível 2 da BM\&F-Bovespa estão, inclusive, obrigadas a adotar o mandato unificado de 2 (dois) anos para os membros do conselho de administração, conforme item 4.4 do Regulamento do Novo Mercado BM\&FBovespa e item 5.4 do Regulamento do Nível 2 da BM\&F-Bovespa.

${ }^{326}$ A terminologia é utilizada em alusão às batalhas medievais, nas quais o cavaleiro branco opunha-se ao cavaleiro negro. Na linguagem dos financeiros, o ofertante contrário à administração da companhia seria o cavaleiro negro, enquanto o ofertante amigável seria o cavaleiro branco (cf. OSÓRIO, José Diogo Horta. Da Tomada do Controlo de Sociedades (takeovers) por Leveraged Buy-Out e sua Harmonização com o Direito Português. Coimbra: Almedina, 2001, p. 130).

${ }^{327}$ De acordo com o Black’s Law Dictionary, a expressão white knight significa “a person or a corporation that rescues the target of an unfriendly corporate takeover, esp. by acquiring a controlling interest in the target corporation or by making a competing tender offer. - Also termed friendly suitor" (GARNER, Bryan A. Black’s Law Dictionary. 4. ed. Saint Paul: West Group, 2001, verbete “white knight”, p. 1591).

${ }^{328}$ A tentativa frustrada de aquisição do controle da Gucci pela Louis Vuitton Moët Henessy ("LVMH”) é um exemplo recente de utilização de white knight. A LVMH tentava tomar o controle da Gucci mediante escalada acionária, quando a Gucci pôs em prática uma medida defensiva de white squire (no caso, outorga de um plano de opção de compra de ações para os seus empregados), com o intuito de diluir a participação do adquirente. Entretanto, tal medida defensiva foi contestada perante o Poder Judiciário da Holanda, onde estão listadas as ações da Gucci. Sendo assim, esta última contatou o grupo francês Pinault-Printemps-Rédoute, que, agindo como white knight e formulando oferta concorrente, impediu a tomada de controle pela LVMH, e, mediante um acordo, terminou por adquirir o controle da Gucci. Para maiores informações sobre o caso, referir-se a LOPEZ, Ernesto Adolfo Hernandez. Bag Wars and Bank Wars, the Gucci and Banque National de Paris Hostile Bids: European Corporate Culture Responds to Active Shareholders. Fordham Journal of Corporate \& Financial Law. v. 9, n. 1, pp. 127-190, 2003. Disponível em SSRN: $<$ http://ssrn.com/abstract=809985 $>$. Acesso em 12.12.2009.
} 
amigável, alinhado com a administração e/ou determinados grupos de acionistas da companhia-alvo $^{329}$.

O cavaleiro branco representará a existência de mais de uma oferta de aquisição de controle, que poderá ter efeito semelhante a um leilão, com ofertas concorrentes, no qual há tendência de apresentação de propostas mais atrativas pelo ofertante que efetivamente estiver interessado em adquirir o controle da companhiaalvo $^{330}$. Além disto, a existência de uma oferta concorrente reduz o grau de coercitividade para aceitação da oferta pública existente ${ }^{331}$.

Conforme examinado no item 4.8, as ofertas concorrentes tendem a aumentar os preços oferecidos ao mercado. É importante lembrar que o artigo 12, §5º da Instrução $\mathrm{CVM} \mathrm{n}^{0}$ 361/02 exige que "quando se tratar de oferta paga à vista, a oferta concorrente deve ser no mínimo 5\% superior ao valor da oferta original”. Sob este ponto de vista, a adoção da medida defensiva do cavaleiro branco teria um efeito positivo, no atendimento do interesse dos acionistas da companhia-alvo, em maximizar o valor de negociação de suas ações diante de potencial tomada de controle.

Entretanto, a experiência norte-americana revela que há ocasiões em que a negociação entre a administração da companhia-alvo e o cavaleiro branco pode estar associada à previsão de privilégios conferidos pela companhia-alvo ao cavaleiro branco, inclusive no que tange ao tratamento diferenciado no ambiente negocial, consistente no compromisso de recomendação aos acionistas para aceitação da proposta realizada pelo cavaleiro branco. Em contrapartida, o cavaleiro branco assume o compromisso de não substituir os membros da administração da companhia-alvo, caso seja concretizada a tomada de controle da companhia-alvo pelo cavaleiro branco.

Embora esta postura seja altamente desaconselhada pela doutrina nos EUA, sob o argumento de violação do dever fiduciário dos administradores de maximizar o valor

\footnotetext{
${ }^{329}$ EISENBERG, Melvin Aron; CARY, William L. Corporations: Cases and Materials. 7. ed. Nova York: Foundation Press, 1995, p. 805.

${ }^{330}$ BAUMAN, Jeffrey D.; WEISS, Elliot J.; PALMITER, Alan R. Corporations - Law and Policy Materials and Problems. 5. ed. Saint Paul: Thomson - West Group, 2003, p. 1100.

${ }^{331}$ Há quem sustente, em contrário, que a oferta concorrente (white knight) não reduz a coerção para aceitação da oferta pública realizada (MUCCIARELLI, Federico M. White Knights and Black Knights: Does the Search for Competitive Bids Always Benefit the Shareholders of 'Target' Companies?. 15.06.2006. Disponível em SSRN: <http://ssrn.com/abstract=910220>. Acesso em 12.12.2009).
} 
de negociação das ações de emissão da companhia-alvo, a fim de privilegiar interesse egoístico de conservação de seus respectivos cargos, os tribunais norte-americanos dividem-se no que tange à aceitação da exequibilidade das chamadas no-shop clauses, que usualmente estabelecem estes compromissos entre a administração da companhia-alvo e o cavaleiro branco ${ }^{332}$.

A medida defensiva do cavaleiro branco também apresenta outros inconvenientes à sua adoção, uma vez que nem sempre haverá um ofertante amigável, capitalizado e interessado em realizar expressivo desembolso, no momento em que o ofertante hostil apresentar oferta destinada à tomada de controle da companhia-alvo.

Além disso, em alguns contextos, defesas por meio de cavaleiros brancos podem se revelar ineficientes, em virtude da necessidade de eventuais aprovações regulatórias e/ou concorrenciais aplicáveis, notadamente quando realizadas em setores submetidos à regulação específica. Em regra, aplicar-se-ão ao cavaleiro branco as mesmas formalidades de aprovação aplicáveis ao ofertante hostil que, por ter realizado sua oferta primeiro, contará com uma vantagem de ordem temporal por ter iniciado os procedimentos de aprovação primeiro do que o cavaleiro branco.

Com ressalvas tendentes a evitar possíveis disfunções decorrentes da utilização de tal medida defensiva, a mesma revela-se atraente nas estratégias defensivas diante de tentativas de tomada de controle. Tanto é assim que a própria Europa, que por conta da Diretiva $n^{0}$ 2004/25/CE ${ }^{333}$ adotou recomendações de neutralidade à administração após o lançamento de uma oferta pública, excepciona esta postura imparcial ao autorizar que a administração da companhia submetida à oferta pública procure ofertas concorrentes, conforme previsto expressamente no artigo $9^{\circ}$, item (2), da Diretiva $n^{\circ}$ 2004/25/CE ${ }^{334}$.

\footnotetext{
${ }^{332}$ Para maiores detalhes, referir-se a William L. Carry e Melvin Aron Eisenberg (EISENBERG, Melvin Aron; CARY, William L. Corporations: Cases and Materials. 7. ed. Nova York: Foundation Press, 1995). Os casos citados em relação a esta divergência de postura dos tribunais são, de um lado, o caso Jewel Companies, Inc v. Pay Less Drug Stores Norhwest, Inc. (741 F.2d 1555, Corte Federal de Apelação do $9^{\circ}$ Circuito, 1984, Rel. Stephen Roy Reinhardt), em que houve a aceitação de uma no-shop clause e, de outro lado, o caso Great Western United Corp. v. Great Western Producers Co-Op. (613 P.2d 873, Colorado, 1980, Rel. Luis D. Rovira).

${ }^{333}$ A Diretiva no 2004/25/CE e o exemplo da Europa em relação à neutralidade da administração serão examinados no item 9.1 deste trabalho.

${ }^{334}$ De acordo com o artigo $9^{\circ}$, item (2), da Diretiva $n^{\circ}$ 2004/25/CE “[...] o órgão de administração da sociedade visada é obrigado a obter a autorização prévia da assembleia geral de acionistas para o efeito antes
} 
Entendemos que o cavaleiro branco (white knight) é uma medida defensiva que pode funcionar perfeitamente no Brasil, estando inclusive prevista e devidamente regulada entre nós com o instituto da oferta pública concorrente ${ }^{335}$. A postura do administrador em buscar outras opções de ofertas públicas paralelamente à tentativa de tomada de controle da companhia é, em nossa opinião, inclusive uma tarefa decorrente dos deveres legais impostos pelos artigos 153 a 158 da Lei $n^{\circ}$ 6.404/76 aos administradores das companhias.

O acordo que vier a ser estabelecido com o cavaleiro branco deve ser orientado pelo interesse social e não deve suscitar prejuízos para a companhia e/ou seus acionistas para satisfazer o interesse dos administradores. Eventuais disfunções deverão ser tratadas com o rigor da lei, inclusive com a responsabilização dos administradores, sempre que aplicável.

\subsection{ESCUDEIRO BRANCO (WHITE SQUIRE)}

O escudeiro branco, usualmente referido por sua tradução em inglês white squire, é a medida defensiva adotada pela companhia-alvo por meio da qual são convidados terceiros, amigáveis à administração e/ou à determinados grupos de acionistas relevantes da companhia-alvo, para adquirem participação acionária, a fim de apoiar a administração e/ou determinados grupos de acionistas relevantes da companhia-alvo, fazendo com que esta se sinta mais protegida contra ofertas hostis. Sua existência desestimularia a oferta hostil pela dificuldade e pelo alto preço que eventual ofertante teria que pagar para a obtenção do controle.

O escudeiro branco (white squire) é instrumento de defesa, apenas, e não implica alteração de controle. Segundo Alexandre Couto Silva, o escudeiro branco distingue-se do cavaleiro branco, pois este visa ao controle da companhia enquanto aquele

de empreender qualquer ação suscetível de conduzir à frustração da oferta, excetuando a procura de outras ofertas [...]”.

${ }^{335}$ A oferta pública concorrente está prevista no artigo 262 da Lei ${ }^{\circ}$ 6.404/76 e regulamentada, em detalhe, na Instrução CVM nº 361/02. 
não possui tais pretensões ${ }^{336}$. Alexandre Couto Silva prossegue oferecendo exemplos de escudeiros brancos, como as compra e venda de ações ou outras transferências de ações para terceiros amigáveis, o ESOPs (Employee Stock Option Plan), os bancos de investimento ou os empréstimos-ponte (bridge financing) para realização de reestruturação de dívidas ou outras operações societárias.

A defesa do escudeiro branco, que envolverá a colocação de um bloco de ações votantes nas mãos de pessoa amigável à companhia-alvo, de maneira geral, tende a ser mais agilmente realizada do que uma defesa através de um cavaleiro branco. A aquisição de participação acionária relevante, porém, sem o condão de promover tomada de controle, tende a ser mais simples do que operações que tenham o efeito de tomar o controle.

Assim como o cavaleiro branco (white knight), o escudeiro branco (white squire) pode funcionar no Brasil como uma medida defensiva a ser adotada pela administração da companhia-alvo contra a tentativa de tomada de controle, de acordo com o nosso regime jurídico pátrio, com cuidados tendentes a evitar desvios e disfunções.

Registre-se aqui, novamente, que eventual acordo estabelecido entre a companhia-alvo e o escudeiro branco deve ser orientado pelo interesse social e não suscitar prejuízos para a companhia e/ou seus acionistas para satisfazer o interesse dos administradores em que a operação de tomada de controle não seja concluída com o terceiro hostil.

\section{JÓIA DA COROA (CROWN JEWEL)}

A jóia da coroa (crown jewel) ${ }^{337}$ é uma medida defensiva contratual, que consiste na venda ou na outorga de opção de compra a terceiros, usualmente cavaleiros

\footnotetext{
${ }^{336}$ SILVA, Alexandre Couto. Responsabilidade dos Administradores de S/A: Business Judgment Rule. Rio de Janeiro: Elsevier, 2007, p. 216.

${ }^{337}$ De acordo com o Black's Law Dictionary, a expressão greenmail significa “1. the act of buying enough stock in a company to threaten a hostile takeover and the selling the stock back to the corporation at an inflated price. 2. the money paid for stock in the corporation's buyback" (GARNER, Bryan A. Black's Law Dictionary. 4. ed. Saint Paul: West Group, 2001, verbete “greenmail”, p. 709).
} 
brancos (white knights) alinhados com a administração e/ou acionistas relevantes da companhia-alvo, tendo por objeto ativos relevantes da companhia-alvo, referidos como as “jóias da coroa”" ${ }^{338}$. Com esta defesa, busca-se reduzir a atratividade da companhia-alvo para o ofertante hostil interessado na aquisição de seu controle ${ }^{339}$.

Essa espécie de medida defensiva, com forte inspiração em exemplos dos EUA, deve ser analisada com restrições no Brasil. De forma geral, alienação de ativos relevantes da companhia é um ato que requer atenção especial, razão pela qual são frequentes disposições estatutárias em companhias abertas brasileiras limitando a alçada dos órgãos de administração e estabelecendo que operações, a partir de determinado montante, requerem aprovação prévia da assembleia geral.

Além disso, dentre as modalidades legalmente previstas de exercício abusivo do poder de controle, a alínea ' $a$ ' do artigo $117, \S 1^{\circ}$, da Lei $n^{\circ}$ 6.404/76 prevê “orientar a companhia para fim estranho ao objeto social ou lesivo ao interesse nacional, ou levá-la a favorecer outra sociedade, brasileira ou estrangeira, em prejuízo da participação dos acionistas minoritários nos lucros ou no acervo da companhia, ou da economia nacional”. Este conceito é desenvolvido no artigo $1^{0}$, inciso III, da Instrução CVM n 323/00, ao restringir "a alienação de bens do ativo, constituição de ônus reais, a prestação de garantias, bem como a cessação, a transferência ou a alienação, total ou parcial, de atividades empresariais, lucrativas ou potencialmente lucrativas, no interesse preponderante do acionista controlador”.

De maneira geral, a conduta de alienar ativos relevantes da companhia para torná-la menos atrativa não é uma prática alinhada com os ditames do interesse social e da busca pelo fim social, razão pela qual deve haver um fundamento razoável que o justifique.

Em consonância com as reflexões do item 5.2, o exame de validade desta defesa, na dimensão do direito civil, requer, além do preenchimento dos requisitos do artigo 104 do Código Civil, a compatibilidade da defesa com os preceitos de ordem pública

\footnotetext{
${ }^{338}$ EISENBERG, Melvin Aron; CARY, William L. Corporations: Cases and Materials. 7. ed. Nova York: Foundation Press, 1995, p. 805.

${ }^{339}$ LEITÃO, Luís Manuel Teles de Menezes. As medidas defensivas contra uma oferta pública de aquisição hostil. O Direito. Ano 138, t. III, Coimbra: Almedina, 2006, p. 464.
} 
do sistema jurídico brasileiro, de modo a não violar o disposto no parágrafo único do artigo 2035 do Código Civil.

Neste compasso, há patente incompatibilidade na adoção de defesas tendentes a violar a função social do contrato e a boa-fé objetiva, respectivamente previstas nos artigos 421 e 422 do Código Civil. Pode ser difícil justificar a venda dos principais ativos da companhia, a fim de se tornar menos atrativa contra eventual tomada de controle, sob a ótica civilista dos referidos princípios.

A postura da administração ao alienar seus principais ativos deve ter sido orientada, por exemplo, pelo objetivo de evitar consequências ainda mais adversas. Nesta compreensão, deve-se ter em mente, tanto quanto possível, a defesa dos interesses da pluralidade de seus acionistas, dos trabalhadores, da comunidade em que atua e de eventuais terceiros com os quais se relaciona. Atuando desta maneira, a adoção da medida defensiva estará provavelmente atendendo ao interesse social.

Contudo, se a atuação estiver pautada na persecução de alguma vantagem pessoal aos administradores, a prática estará eivada de vício. Pode-se extrair lição, neste sentido, de Alfredo Lamy Filho e José Luiz Bulhões Pedreira, embora analisando situação absolutamente diversa ${ }^{340}$ :

\begin{abstract}
Prejuízos causados à companhia, a acionista ou a terceiro - O ato ilícito praticado pelo administrador no exercício de sua função pode ser causa de prejuízo ao patrimônio da companhia, de acionista ou de terceiro.

São exemplos de atos ilícitos de que decorre prejuízo para o patrimônio da companhia [...] a venda de produto da empresa a preço inferior ao de mercado em troca de vantagem pessoal.
\end{abstract}

De forma geral, a alienação por administradores de ativos sociais relevantes não nos parece ser a postura mais alinhada com os deveres impostos pelos artigos 153 a 158 da Lei $n^{\circ}$ 6.404/76, especialmente quando a alienação for realizada por preço vil. A atuação

\footnotetext{
${ }^{340}$ LAMY FILHO, Alfredo; BULHÕES PEDREIRA, José Luiz. A Lei das S.A. v. 2, parte 3, 2. ed. Rio de Janeiro: Renovar, 1996, p. 406.
} 
dos administradores, neste sentido, é tendente a ser questionada perante o Poder Judiciário $^{341}$.

Para evitar questionamentos quanto à validade da utilização da defesa jóia da coroa, a administração da companhia-alvo deve se resguardar com argumentos que demonstrem as razões e eventuais vantagens auferidas com a negociação de seus ativos mais relevantes, capaz inclusive de provocar a redução de sua atratividade.

Deve-se ter atenção, também, às alienações de ativos relevantes utilizados na prestação de garantias pela companhia-alvo. São usuais defesas terra-arrasada (scorchedearth defense) em que os ativos relevantes são atribuídos como garantia em empréstimos da companhia, contendo previsão de vencimento antecipado em caso de mudança do controle. Operações nestes moldes não devem ser concebidas como engrenagem para

\footnotetext{
${ }^{341}$ Uma análise da experiência dos tribunais brasileiros revela alguns exemplos neste sentido. Confira-se, a título de exemplo: “Agravo de instrumento - Execução por título extrajudicial - Contrato de investimento em gado bovino - Não localização da empresa devedora ou de bens suscetíveis de arresto - Enormes evidências de fraude na administração da empresa, em detrimento dos investidores, entre as quais, a dissipação de bens, inclusive dos reservados como garantia pígnoratícia da operação - Responsabilidade do administrador da companhia, em tese, nos termos do art. 158, I e II, e art. 177, § $1^{\circ}$, ' 'c', da Lei das Sociedades Anônimas Cabível a aplicação do instituto da desconsideração da personalidade jurídica, consoante o art. 50 do CC e art. 28 e $\$ 5^{\circ}$, do CDC - Possibilidade de o instituto ser aplicado no processo de execução, para ensejar a inclusão do administrador no pólo passivo e a constrição de bens a ele pertencentes, porque fortíssimas as evidências de fraude e porque haverá oportunidade de cognição plena, no âmbito de eventuais embargos Possibilidade, pelos mesmos argumentos e nas mesmas condições, de estender a execução e, conseqüentemente, a constrição de bens, a pessoa jurídica aparentemente criada para servir como um dos instrumentos de consecução da fraude" (TJSP, 25 $5^{\mathrm{a}}$ Câm. $3^{\circ}$ Grupo - Extinto $2^{\circ}$ TAC, AI 1076336000, Rel. Des. Ricardo Pessoa de Mello Belli, j. 10.10.2006, v.u.); "Ação de indenização - Grupo empresarial - Ação ajuizada por ex-sócios de empresa que detém participação em outras - Extinção sem resolução do mérito Indeferimento da petição inicial Inconformismo - Desacolhimento - Falta de pedido expresso - Causa de pedir imprecisa - Situação incontornável diante do emaranhado de fatos e pessoas jurídicas e físicas agrupadas numa mesma demanda - Sentença mantida - Recurso desprovido. Honorários advocatícios Fixação em R \$ 1.000,00, para todos os réus - Inconformismo dos réus - Acolhimento - Local de realização do serviço e complexidade da controvérsia que autorizam a majoração - Verba honorária fixada em R\$ 5 000,00. - Recursos providos” (TJSP, 9a CC, AC 281.2 99-4/9-00, Rel. Des. Grava Brazil, j. 12.08.2008, v.m.). Veja-se, ainda, trecho de decisão do Tribunal de Justiça de Minas Gerais: "É verdade que o 'bem' objeto da compra e venda são as ações da sociedade Matadouro Itaobim S/A - Maisa. Contudo, o imóvel e respectivo parque industrial fazem parte do ativo imobilizado e patrimônio da empresa, influenciando, sobremaneira, no valor comercial das suas ações. [...] Ocorre que, após pagar apenas 2 (duas) das 72 (setenta e duas) parcelas contratuais, os adquirentes do Matadouro Itaobim S/A (Sr. Alex e Sr. Jonathan) convocaram assembléia geral extraordinária, com o fito de obter autorização para alienação dos ativos imobilizados da empresa, o que, sem sombra de dúvida, viola o contrato. Ato contínuo, aprovou-se a transferência dos bens da sociedade por valor inferior a $25 \%$ do preço pago pelos adquirentes, qual seja, $\mathrm{R} \$ 4.000 .691,08$ (quatro milhões seiscentos e noventa e um reais e oito centavos) - (f. 59 e 65, TJ). Registre-se que a autorização para venda da integralidade dos bens empresariais por cerca de $1 / 4$ (um quarto) do preço pago constitui forte indício hábil a recomendar a concessão da liminar pleiteada, destinada a salvaguardar os direitos da parte agravada” (TJMG, $17^{\mathrm{a}}$ CC, AI 1.0414.08.024224-4/001(1), Rel. Des. Lucas Pereira, j. 04.06.2009, v.m.).
} 
justificar alienação de ativos relevantes ${ }^{342}$, mas devem ser analisadas de forma mais branda e não condenadas previamente, pois a prestação da garantia pode ter sido realizada no curso normal dos negócios da companhia e alinhada com os ditames legais.

\section{GREENMAIL}

A medida defensiva do greenmail $^{343}$ consiste na compra, pela companhia-alvo, de ações detidas por potencial adquirente hostil, com um prêmio relevante sobre o valor das mesmas, a fim de que ele deixe de comprar novas ações ${ }^{344}$. Como destaca Luís Menezes Leitão, esta medida defensiva pouco agrada aos administradores, já que estes se veem obrigados a ceder à chantagem do ofertante hostil ${ }^{345}$.

A terminologia greenmail $^{346}$ revela jogo de palavras com o termo blackmail (chantagem em inglês) e a expressão green em referência a dinheiro. No Brasil e em Portugal, esta espécie de defesa vem sendo referida por sua expressão em inglês, por ausência de tradução apropriada ao nosso idioma.

De modo a evitar que as companhias abertas estejam suscetíveis à ação de greenmailers, isto é, os participantes do mercado tendentes a valer-se de táticas de greenmail, é comum a inclusão em estatutos sociais e/ou documentos constitutivos de

\footnotetext{
342 Sobre operações nestes moldes, referir-se às medidas defensivas de terra arrasada (scorched-earth defense), que consistem em combinação do vencimento antecipado de endividamentos da companhia-alvo, com a venda de seus ativos mais relevantes. A este respeito, confiram-se os breves comentários da nota de rodapé $n^{\circ} 367$, mais adiante.

${ }^{343}$ Também denominada como bon voyage bonus ou goodbye kiss (LEITÃO, Luís Manuel Teles de Menezes. As medidas defensivas contra uma oferta pública de aquisição hostil. O Direito. Ano 138, t. III, Coimbra: Almedina, 2006, p. 464).

${ }^{344}$ CLARK, Robert Charles. Corporate Law. Boston / Toronto: Little, Brown and Company, 1986, p. 574, lembrando que outros acionistas podem considerar a medida inaceitável, por implicar tratamento não igualitário.

${ }^{345}$ LEITÃO, Luís Manuel Teles de Menezes. Op. cit., p. 464.

${ }^{346}$ De acordo com o Black’s Law Dictionary, a expressão greenmail significa “ 1 . The act of buying enough stock in a company to threaten a hostile takeover and then selling the stock back to the corporation at an inflated price. 2. The money paid for stock in the corporation's buyback. 3. A shareholder's act of filing or threatening to file a derivative action and the seeking a disproportionate settlement" (GARNER, Bryan A. Black’s Law Dictionary. 4. ed. Saint Paul: West Group, 2001, verbete “greenmail”, p. 709).
} 
companhias norte-americanas de disposições contra o greenmail (antigreenmail amendments) ${ }^{347}$.

São disposições prevendo que a companhia somente poderá realizar o pagamento dos prêmios associados aos greenmails mediante aprovação da maioria do capital votante, em assembleia geral. A necessidade da realização da assembleia geral e a visibilidade associada a tal evento societário desencorajavam a atuação oportunista e, quiçá, chantagista, dos acionistas dispostos a se valerem de greenmails.

No Brasil, deve-se atentar para as limitações para a companhia adquirir suas próprias ações, conforme artigo 30 da Lei $n^{\circ} 6.404 / 76^{348}$ e Instrução CVM n ${ }^{\circ}$ 10/80. Além disto, há vedação de aquisição pela companhia de suas próprias ações enquanto estiver em curso uma oferta pública de aquisição, nos termos do artigo $2^{\circ}$, alínea (e), da Instrução $\mathrm{CVM} \mathrm{n}^{\mathrm{o}} 10 / 80^{349}$.

Apontando para tais aspectos, Fábio Konder Comparato e Calixto Salomão Filho revelam postura de restrição ao greenmail no Brasil ${ }^{350}$.

Como se não bastasse, o greenmail é uma operação de recompra realizada entre a companhia e um acionista específico. Sob esta perspectiva, a operação pode vir a representar tratamento diferenciado da companhia em relação a tal acionista que será contraparte na recompra necessária a concluir o greenmail.

\footnotetext{
${ }^{347}$ Embora não destinadas a combater os greenmails, são comuns no Brasil disposições em estatutos sociais de companhias abertas exigindo aprovação da assembleia geral para que a administração possa realizar aquisições em valores expressivos.

${ }^{348} \mathrm{O}$ caput do artigo 30 da Lei ${ }^{\circ}$ 6.404/76 prevê que "a companhia não poderá negociar com as próprias ações”. O $\S 1^{\circ}$ deste mesmo dispositivo legal estabelece excepcionalmente que, nessa proibição não se compreendem: a) as operações de resgate, reembolso ou amortização previstas em lei; b) a aquisição, para permanência em tesouraria ou cancelamento, desde que até o valor do saldo de lucros ou reservas, exceto a legal, e sem diminuição do capital social, ou por doação; c) a alienação das ações adquiridas nos termos da alínea b e mantidas em tesouraria; e d) a compra quando, resolvida a redução do capital mediante restituição, em dinheiro, de parte do valor das ações, o preço destas em bolsa for inferior ou igual à importância que deve ser restituída.

${ }^{349} \mathrm{O}$ artigo $177, \S 1^{\circ}$, inciso IV, do Código Penal prevê que incorre em pena de reclusão, de um a quatro anos, e multa "[...] o diretor ou o gerente que compra ou vende, por conta da sociedade, ações por ela emitidas, salvo quando a lei o permite".

${ }^{350}$ COMPARATO, Fábio Konder; SALOMÃO FILHO, Calixto. O Poder de Controle na Sociedade Anônima. 4. ed. Rio de Janeiro: Forense, 2005, pp. 248-249.
} 
A legislação acionária brasileira é estruturada de modo a assegurar tratamento igualitário entre acionistas detentores de ações de mesma espécie e classe. O $\S 1^{\circ}$ do artigo 109 da Lei $n^{\circ}$ 6.404/76 prevê expressamente que "as ações de cada classe conferirão iguais direitos aos seus titulares”. Sendo assim, será assegurado a todos os acionistas detentores de ações da mesma espécie e classe daquela detida pelo greenmailer o direito de participar da operação de recompra a ser realizada pela companhia. Desta maneira, desnatura-se o greenmail e ainda se criam meios para que haja interferência dos demais acionistas na operação de recompra pretendida.

Por estas razões, entendemos que o greenmail é inaplicável ao Brasil.

\subsection{DEFESA PAC-MAN}

A defesa pac-man ${ }^{351}$, cuja nomenclatura se inspira em famoso jogo de vídeogame da década de 1980, é uma contra-oferta mediante lançamento de uma oferta sobre as ações de emissão do capital social do ofertante, movida pela sociedade visada ou por terceiro $^{352}$. A defesa pac-man pode também ser referida como contra-OPA ou contragolpe, em tradução à expressão “turnabout”,353.

Tal medida consiste em contra-ataque da companhia-alvo direcionado ao ofertante. Isto é, enquanto a companhia-alvo é atacada pelo ofertante hostil, que pretende adquirir seu controle por meio de oferta pública, ela contra-ataca o ofertante hostil, tentando adquirir-lhe o controle acionário, em aplicação prática do provérbio latino “si vis pacem, para bellum” (se queres a paz, prepara-te para a guerra).

\footnotetext{
${ }^{351}$ De acordo com o Black’s Law Dictionary, a expressão pac-man defense significa “an aggressive antitakeover defense by which the target company attempts to take over the bidder company by making a cash tender offer for the bidder company's shares. The name derives from a video game popular in the 1980s, the object of which was to gobble up the enemy. This defense is seldom used today" (GARNER, Bryan A. Black's Law Dictionary. 4. ed. Saint Paul: West Group, 2001, verbete “pac-man defense”, p. 1133).

${ }^{352}$ Ibid., p. 465; e também MERLE, Philippe. Droit commercial: sociétés commerciales, 10. ed. Paris: Dalloz, 2005, p. 807. Ambos os autores reconhecem a baixa probabilidade de utilização deste mecanismo de defesa.

353 Robert Clark utiliza a denominação turnabout para esta tática de defesa (CLARK, Robert Charles. Corporate Law. Boston / Toronto: Little, Brown and Company, 1986, pp. 575-576).
} 
É importante especificar que a defesa pac-man não é uma oferta pública concorrente. Trata-se de duas ofertas públicas distintas. Enquanto a oferta concorrente tem por objeto a companhia-alvo simultaneamente à(s) outra(s) oferta(s) pública(s) de aquisição de controle da companhia-alvo, a defesa pac-man é uma oferta pública realizada pela companhia-alvo tendo como objetivo adquirir o controle da companhia que estiver, concomitantemente, tentando adquirir o seu controle.

A defesa pac-man é um contra golpe, não lhe sendo aplicáveis, em nosso entender, as exigências legais pertinentes à oferta concorrente. Não há disposição legal neste sentido e trata-se de ofertas públicas distintas, tendo como objeto companhias diferentes. Neste ponto, data máxima venia, discordamos da respeitável opinião de Vera Helena de Mello Franco, que entende aplicarem-se à “contra-OPA” os mesmos requisitos e procedimentos da oferta concorrente ${ }^{354}$.

A defesa pac-man pode ser utilizada no sistema jurídico brasileiro e, uma vez respeitadas as regras típicas de quaisquer ofertas públicas voluntárias realizadas no Brasil, estará perfeitamente adequada ao nosso sistema. Pondere-se, entretanto, que a aplicação entre nós é coerente apenas na hipótese de a companhia ofertante também ser companhia aberta e possuir estrutura de capital dotada de dispersão acionária, tornando possível a aquisição de seu controle, via operação pública. Em qualquer outro caso, a ideia da defesa pac-man seria fonte de inspiração, mas não teria a mesma aplicação.

\subsection{PÁRA-QUEDAS DOURAdo (GOLDEN PARACHUTE)}

Os pára-quedas dourados, que são frequentemente referidos pela expressão em inglês golden parachute ${ }^{355}$, são medidas defensivas estabelecidas por meio de contratos

\footnotetext{
354 "Tanto a concorrente como a contra-OPA estão sujeitas aos mesmos requisitos e procedimentos da oferta com que concorre [...]” (FRANCO, Vera Helena de Mello. Considerações sobre as Ofertas Públicas para Aquisição de Ações (OPAs): estado atual da questão. RDM. São Paulo: Malheiros, n. 144, pp. 16-58, out./dez. 2006, p. 29).

${ }^{355}$ De acordo com o Black’s Law Dictionary, a expressão golden parachute significa "an employmentcontract provision that grants an upper-level executive lucrative severance benefits - including long-term
} 
celebrados entre, de um lado, a companhia-alvo e, de outro lado, seus altos administradores e profissionais estratégicos ${ }^{356}$. Estabelece-se, nestes contratos, que em caso de transferência do controle da companhia-alvo, a eles serão atribuídas compensações econômicas.

Dessa maneira, os valores dos pacotes de remuneração dos administradores e profissionais estratégicos da companhia-alvo são aumentados em elevado grau no caso de sucesso de oferta pública para aquisição de controle ${ }^{357}$. Sob o ponto de vista do ofertante hostil, tal medida defensiva representa custo adicional a ser incorrido após a realização do takeover hostil e, em alguns casos, capaz de causar a descapitalização da companhiaalvo $^{358}$ e funcionar como desestímulo à tomada de controle.

O argumento usualmente utilizado em defesa da adoção dos pára-quedas dourados é a ideia de assegurar estabilidade à companhia-alvo e retenção de seus profissionais estratégicos; ainda que a companhia esteja diante de uma tentativa de tomada de controle. Há o reconhecimento de que uma companhia em situação de mudança de controle torna-se vulnerável à perda de seus principais profissionais. A instabilidade associada à possível transferência do controle tornam executivos e profissionais estratégicos mais suscetíveis a aceitar eventuais propostas de trabalho realizadas neste contexto.

Entretanto, discute-se se este mecanismo de defesa beneficia os acionistas da companhia-alvo, na medida em que a existência de tal proteção poderia funcionar para os administradores e profissionais estratégicos da companhia-alvo como um elemento capaz de fazer com que estes não resistissem a uma oferta hostil ${ }^{359}$, já que estariam protegidos no caso da tomada do controle sob o ponto de vista financeiro.

salary guarantee or bonuses - if control of the company changes hand (as by a merger)" (GARNER, Bryan A. Black's Law Dictionary. 4. ed. Saint Paul: West Group, 2001, verbete “golden parachute”, p. 700).

${ }^{356}$ É comum a adoção da terminologia pára-quedas prateado (silver parachutes) em referência às medidas defensivas idênticas aos pára-quedas dourado (golden parachutes), porém atribuindo compensações de valor menos expressivo e compreendendo um número maior de profissionais, em hierarquia não tão elevada quanto aquela abrangida pelos pára-quedas dourado (golden parachutes).

${ }^{357}$ CLARK, Robert Charles. Corporate Law. Boston / Toronto: Little, Brown and Company, 1986, p. 577.

${ }^{358}$ CORDEIRO, António Manuel da Rocha e Menezes. Da Tomada de Sociedades (Takeover): Efectivação, Valoração e Técnicas de Defesa. ROA. Lisboa, n. 54, pp. 761-777, 1994, p. 774.

${ }^{359}$ CLARK, Robert Charles. Op. cit., p. 577. 
A previsão da elevada compensação a ser paga aos administradores e profissionais estratégicos da companhia-alvo pode funcionar como indutor para que estes sejam mais tendenciosos a permitir que a tomada de controle seja levada a efeito.

Nos EUA, é grande a polêmica em torno da utilização dos golden parachutes, especialmente pelo fato de que o controle gerencial é usual em inúmeras companhias abertas.

No Brasil, a utilização dos pára-quedas dourados pressupõe uma harmonização com os parâmetros abordados por nós no item 5.2, notadamente no que se refere ao disposto no parágrafo único do artigo 2035 do Código Civil, respeitando-se a função social do contrato e a boa-fé objetiva.

Parece-nos até certo ponto saudável e alinhado com o sistema pátrio, a adoção de medidas que visem à manutenção da estabilidade na condução dos negócios da companhia-alvo, mesmo diante de potencial tomada de controle, sendo que o pára-quedas dourado contribuiria neste sentido. Todavia, tal defesa não deve ser utilizada para perpetrar abusos e/ou propiciar favorecimentos indevidos de administradores e profissionais estratégicos. A apuração do equilíbrio quanto ao conteúdo do programa de retenção de executivos deve ser feito em cada caso concreto.

Carlos Augusto Silveira Lobo reputa ilícitos os golden parachutes, tidos como “atribuição injustificada aos administradores de opções de compra de ações, bônus, gratificações em dinheiro, enormes honorários e outras vantagens extraordinárias a serem pagas no caso de serem exonerados”360. Entendemos que nem todas as defesas de páraquedas dourados são tendentes a serem inválidas e/ou ilícitas, dependendo em todos os casos do conteúdo da avença estabelecida entre a companhia-alvo e os administradores e/ou profissionais estratégicos.

Cabe aqui, também, reflexão sobre a linha tênue que deverá existir na hipótese de os próprios membros da administração da companhia-alvo estarem, na condição de representantes desta última, assegurando para si próprios proteções em caso de mudança

\footnotetext{
${ }^{360}$ LOBO, Carlos Augusto da Silveira. Sociedades coligadas, controladoras e controladas. In: LAMY FILHO, Alfredo; BULHÕES PEDREIRA, José Luiz. Direito das Companhias. v. 2, Rio de Janeiro: Forense, 2009, pp. 2034-2035.
} 
do controle da companhia-alvo. Tal reflexão deve ser rigorosamente orientada pelos deveres atribuíveis aos administradores de companhias, notadamente aqueles previstos nos artigos 153 a 157 da Lei $n^{0}$ 6.404/76.

\subsection{PEOPLE PILL}

Esta medida efetiva-se mediante ameaça de renúncia integral dos membros da administração da companhia-alvo, o que pode desencorajar o adquirente, na hipótese de pretender manter algum ou alguns dos administradores. Trata-se de medida pouco eficaz, porque raros são os casos de manutenção da administração pelo novo controlador $^{361}$.

Pode-se pensar, também, em variação do people pill na qual a aquisição hostil do controle da companhia-alvo ensejará o enrijecimento de relações trabalhistas previstas em acordos coletivos de trabalhadores da companhia-alvo, de modo que estes trabalhadores estejam protegidos contra aquisições hostis de controle capazes de ensejar a subsequente extinção da companhia-alvo, fonte geradora dos empregos de tais trabalhadores. Neste caso, a defesa poderia consistir na debandada dos trabalhadores ou aumento do custo para mantê-los trabalhando, de modo que o ofertante hostil sinta-se menos interessado em adquirir o controle de tal sociedade.

\subsection{SHOW STOPPER OU SAFE HARBOUR}

As medidas defensivas da suspensão do espetáculo (show stopper) ou do porto seguro (safe harbour) consistem em suscitar entraves concorrenciais e/ou atinentes a questões de direito público para dificultar e/ou inviabilizar a tomada de controle.

${ }^{361}$ LEITÃO, Luís Manuel Teles de Menezes. As medidas defensivas contra uma oferta pública de aquisição hostil. O Direito. Ano 138, t. III, Coimbra: Almedina, 2006, p. 464. 
São proteções utilizadas em aquisições de controle de companhias que tenham como atividade, por exemplo, a prestação de serviços públicos ou a realização de obras públicas. São também aplicáveis às companhias que desenvolvam atividade essencial ao interesse ou soberania nacional, negócios estratégicos do Estado e questões de tal natureza que possam envolver, por exemplo, licitações, concessões ou permissões de serviços públicos.

A utilização dessas defesas é também relativa à criação de óbices de direito concorrencial, realizando operações que obrigariam a tomada de controle a ser submetida a aprovação das autoridades estatais competentes pela tutela da ordem econômica nacional.

Em tais hipóteses, uma vez submetida à tentativa de tomada de controle, a administração da companhia-alvo, a fim de dificultar o takeover, submete a operação ao órgão regular, poder concedente ou autoridade antitruste, a fim de criar entrave à operação.

Esta espécie de medida defensiva é referida como show stopper, por interromper o show até a manifestação da autoridade competente; ou como safe harbour, reconhecendo-se na atuação da autoridade competente o “porto seguro" para evitar a tomada do controle.

No Brasil, o envolvimento de autoridades estatais em operações de tomada de controle pode ser alcançado inclusive em decorrência da interpretação ampla do artigo 78, inciso XI, da Lei $n^{\circ} 8.666 / 93^{362}$ ou do disposto no artigo 27 da Lei $n^{\circ} 8.987 / 95^{363}$. Essas medidas defensivas podem também ser utilizadas envolvendo o CADE na apreciação de operações em que se aplique o disposto no artigo 54 da Lei nº 8.884/94.

\footnotetext{
${ }^{362}$ A Lei no 8.666/93, que regula licitações e contratos da administração pública, prevê no inciso XI do artigo 78, que "a alteração social ou a modificação da finalidade ou da estrutura da empresa, que prejudique a execução do contrato" constitui motivo para rescisão do contrato. A autorizada opinião de Marçal Justen Filho compreende casos de transferência de controle no conceito de alteração social previsto no artigo 78, inciso XI, da Lei $n^{\circ}$ 8.666/93. Embora a tomada de controle não seja propriamente transferência de controle, mas sim aquisição originária de controle, como se viu no item 3.1.2, parece-nos que as tomadas de controle também poderiam se enquadrar nesta lógica (JUSTEN FILHO, Marçal. Comentários à lei de licitações e contratos administrativos. São Paulo: Dialética, 2009, p. 818).

${ }^{363}$ A Lei $\mathrm{n}^{\circ} 8.987 / 95$, que regula as concessões e permissões de serviços públicos, prevê no caput do artigo 27, que "a transferência de concessão ou do controle societário da concessionária sem prévia anuência do poder concedente implicará a caducidade da concessão”.
} 
Em todos esses casos, mediante a utilização desta defesa, a operação fica suspensa, interrompe-se o "show" (show stopped), enquanto a autoridade competente não se manifestar em relação à mesma.

Há, na doutrina norte-americana, precedente que pode ser apontado como defesa contra tentativa de tomada de controle mediante adoção de um show stopper. No caso Panter v. Marshall Field \& Co. ${ }^{364}$, a Marshall Field \& Co, companhia atuante no setor de varejo, detentora de cadeia de lojas de departamento, defendeu-se de indesejada tentativa de tomada de controle empreendida por outra companhia do setor de varejo, adquirindo e abrindo novas lojas de departamento, a fim de ampliar seu conceito de mercado relevante no setor de varejo e, deste modo, criando problemas antitruste que inviabilizariam a tomada de controle pelo adquirente indesejado.

\subsection{MACARONi DEFENSE}

A medida defensiva macaroni defense ${ }^{365}$ consiste na emissão de debêntures pela companhia com a obrigação de recompra, com prêmio relevante, no caso de sucesso de oferta hostil de aquisição de controle ${ }^{366}$.

Diante de tal medida defensiva, o interessado em adquirir o controle da companhia deve inicialmente adquirir as referidas debêntures, antes de tentar a tomada de controle, pois a obrigação de recomprá-las, com o elevado prêmio atrelado em caso de tomada de controle, pode representar um desembolso tão alto que inviabilize o próprio takeover.

\footnotetext{
${ }^{364}$ Panter v. Marshall Field \& Co Weiss (646 F.2d 271, Corte de Apelação do $7^{\circ}$ Circuito, 1981, Rel. Wilbur Frank Pell Jr.).

${ }^{365}$ Esta terminologia é atribuída a tal medida defensiva, pela experiência norte-americana, em alusão ao fato de que os prêmios atrelados às debêntures a serem recompradas em caso de tomada de controle são capazes de se expandirem como "macarrão instantâneo em água fervendo”.

${ }^{366}$ LEITÃO, Luís Manuel Teles de Menezes. As medidas defensivas contra uma oferta pública de aquisição hostil. O Direito. Ano 138, t. III, Coimbra: Almedina, 2006, p. 464.
} 
Em alguns casos, há previsão de que o pagamento das debêntures dar-se-á com as ações de emissão da companhia, de modo a transformar o debenturista em acionista, em casos de pagamento das dívidas representadas por aqueles títulos. Nestas hipóteses, o volume de ações a ser adquirido pelo ofertante hostil para que ele assuma o controle da companhia-alvo acabará sendo maior.

A medida defensiva aqui referida consiste na previsão, em contratos de empréstimo e/ou outros contratos relevantes da companhia, de que a transferência do controle implica o vencimento antecipado daquelas obrigações ${ }^{367}$.

No que se refere ao vencimento antecipado dos contratos de empréstimo, a consequência imediata é que a dívida contraída deve ser antecipadamente quitada, subsequentemente à transferência do controle, o que pode causar a descapitalização da companhia ou, até mesmo, obrigá-la a alienar ativos para dispor de recursos para efetuar tal quitação $^{368}$.

Além disso, são comuns os casos em que ativos relevantes da companhia são atribuídos como garantia do pagamento destes empréstimos, de modo que eventual

\footnotetext{
${ }^{367}$ Há situações em que a companhia-alvo combina espécies de medida defensiva, em sua estratégia de proteção ao takeover hostil. A este respeito, denomina-se scorched-earth defense (defesa da terra-arrasada) a combinação do vencimento antecipado dos endividamentos da companhia-alvo, com a venda de seus ativos mais relevantes (as jóias da coroa, referidas no item 6.8). De acordo com o Black's Law Dictionary, a expressão scorched-earth defense significa "an antitakeover tactic by which a target corporation sells its most valuable assets or divisions in order to reduce its value after acquisition and thus try to defeat a hostile bidder's tender offer” (GARNER, Bryan A. Black's Law Dictionary. 4. ed. Saint Paul: West Group, 2001, verbete "scorched-earth defense”, p. 1348). Na doutrina pátria, Paulo Fernando Campos Salles de Toledo tratou justamente deste efeito de combinação do vencimento antecipado de empréstimos com a venda de ativos relevantes da companhia-alvo (jóias da coroa). (TOLEDO, Paulo Fernando Campos Salles de. Poison pill: modismo ou solução?. In: CASTRO, Rodrigo R. Monteiro; ARAGÃO, Leandro Santos de (coord.). Direito Societário: Desafios Atuais. São Paulo: Quartier Latin, 2009, pp. 157-176).

${ }^{368}$ CLARK, Robert Charles. Corporate Law. Boston / Toronto: Little, Brown and Company, 1986, p. 576. Na mesma passagem, Clark ressalta que, em casos regulares, é pouco provável que os credores não renegociem os termos contratuais, sob risco de perda de clientes sem motivos relevantes.
} 
inadimplemento importará no comprometimento de tais ativos e, até mesmo, na inviabilização dos negócios da companhia diante deste embaraço.

No que se refere ao vencimento antecipado de contratos relevantes, a consequência é a extinção de atividade fundamental à condução dos negócios da companhia, seja em relação a importantes clientes, fornecedores, poder concedente, seja em relação a uma infinidade de outras possibilidades, cujos efeitos seriam igualmente terríveis para a companhia.

Estes reflexos são usualmente concebidos a fim de desestimular o ofertante a realizar a tomada de controle da companhia, sob o receio dos custos que terá que suportar e/ou dificuldades que enfrentará na condução dos negócios sociais.

Esta medida defensiva, segundo nos parece, encontraria guarida entre nós. É possível interpretá-la como uma condição imposta pela contraparte no contrato de empréstimo e/ou contrato relevante, a fim de assegurar certas garantias quanto ao cumprimento das obrigações assumidas.

De toda maneira, aplicam-se aqui igualmente as reflexões realizadas no item 5.2, quanto à aplicação do parágrafo único do artigo 2035 do Código Civil, que impõe a primazia dos preceitos de ordem pública, como os instituídos para assegurar a função social da propriedade e dos contratos, devendo-se observar as cláusulas gerais do Código Civil, especialmente a função social do contrato e a boa-fé objetiva.

\subsection{Standstill Agreements}

Os standstill agreements, que em tradução para o nosso vernáculo podem ser referidos como "acordos de paralisação", destinam-se à manutenção do status quo em relação à participação acionária dos acionistas da companhia-alvo e, consequentemente, preservação da estrutura de poder de controle vigente. 
Trata-se de outra forma de medida defensiva comum nos EUA, que se revela estranha à realidade brasileira e que deve ser adequadamente entendida entre nós para que não seja simples e erroneamente replicada no Brasil.

Os standstill agreements são acordos celebrados entre a companhia-alvo e determinado(s) acionista(s) detentor(es) de participação acionária expressiva em seu capital social, que tenha(m) interesse em adquirir ações que lhe conduzam à condição de controlador da companhia-alvo.

A companhia-alvo, a fim de evitar que o acionista venha a tomar o seu controle, celebra com ele um acordo por meio do qual este acionista se compromete a não aumentar a sua participação no capital social da companhia-alvo durante certo período, em troca do pagamento de uma determinada quantia para que conserve patamares acordados de participação acionária na companhia-alvo.

Os standstill agreements são negócios jurídicos que, para serem admitidos no Brasil, devem ser rigorosamente submetidos à análise pelos preceitos referidos no item 5.2, notadamente no que se refere ao disposto no parágrafo único do artigo 2035 do Código Civil e, consequentemente, nos artigos 421 e 422 do Código Civil.

Parece-nos inadequada a adoção de tal defesa paliativa pela companhia-alvo, uma vez que esta poderá incentivar a proliferação de acionistas oportunistas buscando a celebração de negócios jurídicos semelhantes com a companhia-alvo visando à obtenção de compensação semelhante.

\subsection{Apenas Diga Não (JUSt SAY No)}

A medida defensiva do “apenas diga não” (just say no) ${ }^{369}$ consiste na simples rejeição, pelo Conselho de Administração, da oferta pública de aquisição de ações

\footnotetext{
${ }^{369}$ A nomenclatura é alusiva à companhia antidrogas nos EUA, liderada pela então primeira dama norteamericana Nancy Regan, que tinha como slogan a expressão “just say no”.
} 
realizada pelo ofertante, sem que o Conselho de Administração prossiga na resistência à tomada de controle utilizando-se de outras espécies de medidas defensivas ${ }^{370}$.

Por razões estruturais, esta espécie de medida defensiva, aplicável nos EUA, pressupõe que o poder-dever de decidir em relação à oferta pública é atribuído ao Conselho de Administração ${ }^{371}$.

Embora a defesa do “apenas diga não” (just say no) seja referida pela doutrina norte-america como uma espécie independente de medida defensiva, sua aplicação está diretamente associada à existência de planos de poison pill na companhia-alvo ${ }^{372}$, propiciando meios para que a administração simplesmente rejeite a oferta pública que, em seu entender, é hostil, sem sequer estruturar negociação ou esforçar-se para melhorar os termos e condições da oferta pública.

No Brasil, ainda que o envolvimento da administração seja saudável na maioria das operações de tomada de controle, a decisão quanto ao mérito da oferta pública, aceitando-a ou rejeitando-a, cabe aos acionistas, razão pela qual esta defesa é praticamente inaplicável em nosso sistema legal.

\footnotetext{
${ }^{370}$ Em oposição à defesa do "apenas diga não” (just say no), Julian Velasco propõe estratégia para ofertantes hostis contra-atacarem em caso de resistência à tomada de controle pela administração da companhia-alvo. Segundo o autor, tal estratégia visa a devolver aos acionistas da companhia-alvo o direito de poderem vender as suas ações sem a necessidade de consentimento da administração (VELASCO, Julian. Just Do It: An Antidote to the Poison Pill. Emory Law Journal. v. 52, 2003, p. 849. Disponível em SSRN: $<$ http://ssrn.com/abstract=324882>. Acesso em 12.12.2009).

${ }^{371}$ Guhan Subramanian aponta três tentativas de tomada de controle durante a década de 1990 (Younkers, Wallace Computer e Circon), que corporificaram os planos de poison pill e a defesa do "apenas diga não" (just say no) no estado norte-americano de Delaware. Em seguida, o professor da Harvard Law School complementa que a decisão da Suprema Corte de Delaware em 1995, no caso Unitrin v. American General Corp. solidificou a admissibilidade da defesa do "apenas diga não" (just say no). (cf. SUBRAMANIAN, Guhan. The Disappearing Delaware Effect. Harvard Law and Economics Discussion Paper, n. 391, out. 2002. Disponível em SSRN: <http://ssrn.com/abstract=345040>. Acesso em 12.12.2009). Entretanto, a controvertida medida defensiva do "apenas diga não" (just say no) tem sido abordada de forma restritiva pela doutrina norte-americana, em sua concepção moderna do estudo das tomadas de controle e das defesas a elas opostas. Ronald Gilson e Reinier Kraakman propõem que "the capital market will no longer tolerate a just say no defense, so wheter the Delaware Supreme Court will allow it is irrelevant. [...] There we acknowledged that [Martin] Lipton won the legal battle. While leaving the Chancery Court somewhat sullen and sinker - 'just say no' survived at least rhetorically. Today, however, it is sometimes argued that Lipton's victory was a hollow one" (GILSON, Ronald J.; KRAAKMAN, Reinier H. Takeovers in the Boardroom: Burke versus Schumpeter. Stanford Law and Economics Olin Working Paper, n. 306, mai. 2005; Columbia Law and Economics Working Paper, n. 280. Disponível em SSRN: <http://ssrn.com/abstract=732783>. Acesso em 12.12.2009.

${ }^{372}$ VELASCO, Julian. The Enduring Illegitimacy of the Poison Pill. The Journal of Corporation Law. v. 27, n. 3, pp. 381-423, Spring 2002. Disponível em SSRN: <http://ssrn.com/abstract=825046>. Acesso em 12.12.2009.
} 
Diante da situação de potencial tomada de controle da companhia-alvo, é comum e frequente a utilização de batalhas judiciais e/ou arbitrais travadas perante o Judiciário e/ou eventual Tribunal Arbitral competente, empreendidas pela companhia-alvo contra o possível interessado na tomada de seu controle e/ou até mesmo em face de eventuais terceiros e/ou órgãos governamentais. Na maioria dos casos, o objetivo é criar dificuldades à conclusão da tomada de controle e/ou postergar os procedimentos associados à mesma, de modo a propiciar tempo para que a administração da companhiaalvo se estruture para utilizar medidas defensivas mais adequadas em sua estratégia de defesa contra a tomada de controle.

António Menezes Cordeiro, abordando a medida defensiva das batalhas judiciais sob a nomenclatura de batalha legal, ensina que tal espécie de medida defensiva consiste:

em responder a uma OPA através do levantamento de inúmeras dificuldades processuais, suscitando incidentes e multiplicando obstáculos formais. Durante a batalha, os opositores à OPA tentarão adquirir acções pretendidas ou procurarão demover os accionistas dispostos a vender ${ }^{373}$.

Esta medida defensiva estará, na grande maioria dos casos, combinada com a adoção de outras estratégias defensivas. As batalhas judiciais e/ou arbitrais terão por objeto discussões que permearão ilimitados argumentos e teses jurídicas que a criatividade dos advogados envolvidos no caso concreto poderá desenvolver, não apenas no que tange ao direito material, mas também naquilo que se refere ao direito processual, de modo a multiplicar expedientes processuais, criar obstáculos, interpor recursos, sempre com o

${ }^{373}$ CORDEIRO, António Manuel da Rocha e Menezes. Da Tomada de Sociedades (Takeover): Efectivação, Valoração e Técnicas de Defesa. ROA. Lisboa, n. 54, pp. 761-777, 1994, p. 776. 
objetivo maior de propiciar tempo para a estruturação da estratégia defensiva da companhia-alvo.

No Brasil, diante da exigência imposta pelos Regulamentos dos Níveis 1, 2 e Novo Mercado da BM\&F-Bovespa de que as companhias abertas adotem cláusulas de compromisso arbitral, segundo o Regulamento da Câmara de Arbitragem do Mercado, há a tendência de que tais batalhas ocorram perante a Câmara de Arbitragem do Mercado.

\subsection{ForTALECIMENTO DA ESFERA DE CONTROLE}

Embora em nosso entendimento esta não seja propriamente uma espécie de medida defensiva, mas, sim, o abandono da dispersão acionária e migração para a concentração acionária, trataremos o fortalecimento da esfera de controle como mais um dos métodos disponíveis à resistência contra a tomada de controle.

A dispersão acionária é premissa para que as tomadas de controle possam ser realizadas por ofertas públicas voluntárias para aquisição de ações representativas do controle. Sendo assim, diante de tentativa de tomada de controle, acionistas relevantes da companhia-alvo podem se reunir e, conjuntamente, consolidar controle majoritário conjunto em relação a esta última.

A congregação dos acionistas integrantes da dispersão acionária pode se dar por meio de convenções de voto, em especial acordos de acionistas, ou mediante empréstimos de ações que, eventualmente, sejam realizados para que determinado acionista detenha consigo quantidade de ações capaz de resistir à tentativa de tomada de controle. Estas seriam técnicas contratuais para uso da defesa de espécie fortalecimento da esfera de controle.

Pode-se conceber, também, técnicas institucionais para adoção da defesa do fortalecimento da esfera de controle, mediante a formação de organismos como, por exemplo, sociedades holdings, fundos de investimento, trusts, condomínios, consórcios de sociedades, dentre outros. 
Com a consolidação da estrutura de controle majoritário conjunto, torna-se inviável a aquisição do poder de controle sem a negociação com os seus detentores, impedindo, deste modo, o prosseguimento da oferta pública voluntária para a aquisição de ações representativas do poder de controle, por perda de seu objeto.

Embora extremamente eficiente, esta estratégia de defesa contra a tomada de controle pode ser de difícil concretização, uma vez que pressupõe a cooperação de acionistas detentores de ações em quantidade suficiente para estruturar e concentrar o capital votante da companhia.

Além disso, conforme antecipamos no item 5.1.1.2, esta espécie de medida defensiva será obrigatoriamente uma proteção posterior, adotada ad hoc, após o lançamento da oferta pública.

Por coerência técnico-conceitual, esta espécie de medida defensiva jamais poderá ser um método preventivo, pois, se a coordenação existisse antes do lançamento da oferta pública, estabilizando o poder de controle em estrutura de controle majoritário conjunto, a oferta pública sequer seria lançada contra a companhia, por faltar a dispersão acionária indispensável para que a tomada de controle ocorra por oferta pública. 
VII. EFEITOS DAS MEDIDAS DEFENSIVAS

As medidas defensivas produzem diversos efeitos em operações de tomadas de controle $^{374}$, os quais podem ser entendidos como vantajosos ou desvantajosos, dependendo do ponto de vista em relação às defesas. A proposta aqui não é examinar o mérito das proteções, qualificando-as como positivas ou negativas. Este juízo deve ser feito em cada caso concreto. A proposta nesta ocasião é lançar as bases para o entendimento da questão e avaliação da utilização das medidas defensivas.

Os efeitos apontados abaixo não são os únicos decorrentes da utilização de medidas defensivas, mas, talvez, sejam os mais relevantes e, por este critério, foram selecionados para abordagem.

As medidas defensivas promovem um ambiente de segurança, ainda que tênue, em companhias dotadas de dispersão acionária, sob o sentimento de que com tais proteções a companhia está menos vulnerável às tentativas de tomada de controle.

Esta sensação de segurança permite, inclusive, que, em determinados casos, acionistas detentores de participações acionárias expressivas optem por recorrer ao mercado de capitais, promovendo a abertura do capital da companhia e realizando oferta pública de distribuição inicial de ações ${ }^{375}$. A ideia é a de que, embora estruturada com dispersão acionária, a companhia não estará tão exposta à tomada de controle.

\footnotetext{
${ }^{374}$ JARREL, Gregg A.; BRICKLEY, James A.; NETTER, Jeffry M. The Market for Corporate Control: The Empirical Evidence Since 1980. In: ROMANO, Roberta (coord.). Foundations of Corporate Law. 2. re-imp. Nova York: Foundation Press, 2004, p.267.

${ }^{375}$ A este respeito, HANNES, Sharon. The Market for Takeover Defenses. Northwestern University Law Review. v. 101, 2007. Disponível em SSRN: <http://ssrn.com/abstract=926893>. Acesso em 12.12.2009; e Idem. A Demand Side Theory of Anti-Takeover Defenses. Journal of Legal Studies. v. 35, pp. 475-524, 2006. Disponível em SSRN: <http://ssrn.com/abstract=926889>. Acesso em 12.12.2009. Segundo Sharon
} 
De maneira geral, as medidas defensivas são um desincentivo às tentativas de tomada hostil de controle das companhias que as utilizem. Diante de duas companhias igualmente atrativas para um takeover, estando uma delas protegida por medidas defensivas e a outra desprotegida, há a tendência natural de que o interessado em realizar a tomada de controle destine a sua oferta para a companhia desprotegida ${ }^{376}$.

Por estas razões, diz-se que as medidas defensivas têm o efeito de conferir estabilidade para companhias dotadas de dispersão acionária e, deste modo, criar condições para o investimento de longo prazo ${ }^{377}$. A admissibilidade de adoção das medidas defensivas, tendo em vista este sentimento de estabilidade associado às mesmas, parece importante para incentivar o desenvolvimento do mercado de capitais ${ }^{378}$.

Este efeito de estabilidade proporcionada à companhia com dispersão acionária, associado à pretensa segurança promovida pelas medidas defensivas de conservação do poder de controle, é especialmente interessante no momento da abertura do capital da companhia ${ }^{379}$, sendo propenso a atender aos interesses dos acionistas fundadores

Hannes, a decisão de promover a abertura de capital sem a adoção de medidas defensivas é considerada uma decisão de criar um alvo desprotegido para a tomada de controle. Em sentido semelhante: BOULTON, Thomas J. Maintaining Control: The Impact of Antitakeover Provisions on IPO Decisions. 12.06.2009. Disponível em SSRN: <http://ssrn.com/abstract=1418616>.

${ }^{376}$ HANNES, Sharon. The Hidden Virtue of Antitakeover Defenses. Harvard Law School John M. Olin Center for Law, Economics and Business Discussion Paper Series. n. 354, p. 18, 2002. Disponível em $<$ http://www.law.harvard.edu/programs/olin_center/corporate_governance/papers/No354.0.Hannes.pdf $>$.

Acesso em 12.12.2009. Neste ensaio, lê-se: “[...] takeover defenses divert some takeover activity in the marketplace from shielded to unshielded enterprises”.

${ }^{377}$ SRINIDHI, Bin; SEN, Kaustav. Effect of Poison Pills on Value Relevance of Earnings. fev. 2002. Disponível em SSRN: <http://ssrn.com/abstract=302646>.

${ }^{378}$ Em Portugal, António Menezes Cordeiro defende que “[p]arece ser razoável, pelo menos até um certo patamar, facultar medidas defensivas contra tomadas hostis. Repare-se: a não serem de todo possíveis, as empresas poderiam desistir de antemão de recorrer ao mercado de capitais para se autofinanciarem. O crescimento ficaria comprometido. Mais: o próprio mercado mobiliário, carecido de matéria-prima, poderia definhar” (CORDEIRO, António Manuel da Rocha e Menezes. A OPA Estatutária como Defesa contra Tomadas Hostis. ROA, Lisboa, n. 58, pp. 133-145, 1998. p. 135).

${ }^{379}$ Ainda em relação ao efeito da estabilização da dispersão acionária no momento da abertura de capital, Lucian Bebchuk faz interessante ponderação de que a inclusão de medidas defensivas pode decorrer de influência exercida por advogados assessores da companhia na abertura de seu capital e realização de sua oferta pública inicial (IPO). Nas palavras do professor da Harvard Law School: “To the extent that lawyers' expertise gives them influence over decision making, they might have an incentive to tilt their recommendations in favor of antitakeover arrangements. The downside of not having antitakeover protection - that incumbents might find themselves unprotected from a hostile bid down the road - might be attributed to the lawyers and might negatively affect their reputation. Furthermore, the potential upside of not including antitakeover provisions - a slightly higher IPO share price - would hardly be credited to the lawyers' work. Thus, since the adoption of antitakeover provisions provides a benefit but little cost to lawyers, they have an incentive to use their influence over the drafting of the charter to encourage antitakeover arrangements [...]”. (BEBCHUK, Lucian A. Why Firms Adopt Antitakeover Arrangements. University of Pennsylvania Law 
que estiverem realizando a abertura de capital, com a subsequente realização de oferta pública de distribuição de ações. Sob a ótica dos acionistas fundadores, as medidas defensivas podem funcionar como mecanismo para preservação do poder de controle, após a redução de suas participações para aquém de posições de concentração acionária.

Com o decorrer do tempo, após a abertura do capital e a realização da oferta pública de distribuição de ações, há a tendência de que acionistas com perfil de investidores de mercado ${ }^{380}$ não estejam propensos à adoção da medida defensiva por reconhecerem que estas geram um desestímulo ao investimento e podem limitar a valorização das ações.

Lucian Bebchuk, abordando a proteção decorrente das medidas defensivas aos acionistas fundadores e da mudança de comportamento dos acionistas em relação à adoção de medidas defensivas, sintetiza que, no estágio do IPO da companhia, as medidas defensivas são desejáveis, pois encorajam os acionistas fundadores a desfazerem o bloco de controle que existia enquanto a companhia era fechada. Na ausência de tais proteções, os acionistas fundadores não tenderiam a migrar para a dispersão acionária, por meio da abertura de capital. Tão logo as participações acionárias estejam suficientemente dispersas no mercado, de modo que os votos dos acionistas com perfil de investidores de mercado importem para a formação de quorum de deliberação, os benefícios das medidas defensivas tendem a passar a ser questionados. Nos dizeres de Lucian Bebchuk, "this change can explain the midstream opposition of such investors to antitakeover arrengements" 381 .

Em regra, o efeito da estabilização da dispersão acionária visa a satisfazer principalmente os interesses dos acionistas fundadores da companhia, alinhados com a

Review. n. 152, pp. 713-753, 2003; Harvard Law and Economics Discussion Paper. n. 420. Disponível em SSRN: <http://ssrn.com/abstract=404200>. Acesso em: 12.12.2009). Em sentido semelhante, o estudo em que John Coates destaca a influência exercida por advogados na inclusão de medidas defensivas em estatutos sociais de companhias norte-americanas (COATES IV, John C. Explaining Variation in Takeover Defenses: Blame the Lawyers. California Law Review. n. 89, out. 2001. Disponível em SSRN: $<$ http://ssrn.com/abstract=304081 $>$. Acesso em 12.12.2009).

${ }^{380}$ Esta postura dos acionistas com perfil de investidores de mercado é mais clara em relação às medidas defensivas adotadas de forma expressa, como, por exemplo, as estatutárias, já que estas se tornam de conhecimento público e sua existência pode inibir a realização de investimentos na companhia. Em relação às medidas defensivas que possam ser adotadas sem este efeito tão expresso, a postura dos acionistas com perfil de investidores de mercado pode ser outra.

${ }^{381}$ BEBCHUK, Lucian A. Why Firms Adopt Antitakeover Arrangements. University of Pennsylvania Law Review. n. 152, pp. 713-753, 2003; Harvard Law and Economics Discussion Paper. n. 420. Disponível em SSRN: <http://ssrn.com/abstract=404200 $>$. Acesso em: 12.12.2009. 
condução de seus negócios e interessados em conservar seu poder de controle. Por outro lado, sob o ponto de vista dos acionistas investidores de mercado, a proteção à tomada de controle pode representar o cerceamento de um mecanismo disponível para que estes possam negociar suas ações e, deste modo, auferir vantagens econômicas com o investimento detido na companhia.

\subsection{EFEITO No PREÇO DE COMPRA}

As medidas defensivas tendem a elevar o preço de compra de ações de emissão de companhias que as adotem ${ }^{382}$. Este efeito está diretamente associado com a intenção de majorar o desembolso que o ofertante deverá realizar para tomar o controle da companhia, do modo a torná-la menos vulnerável às modificações de controle.

Diante disto, nos casos em que a tomada de controle seja realizada pelo ofertante meramente para obter vantagem financeira, comprando o controle por valor reduzido, com o propósito de posteriormente aliená-lo por valor mais alto, é provável que a oferta seja direcionada à companhia que não adote medidas defensivas e, consequentemente, esteja mais suscetível à tomada do controle ${ }^{383}$.

Além disso, o preço de compra tende a aumentar sob a premissa de que as medidas defensivas, por tornarem a companhia-alvo menos vulnerável à tomada de controle, propiciam mecanismos para que a administração e/ou os próprios acionistas da companhia-alvo negociem melhores condições para a venda das ações ${ }^{384}$.

\footnotetext{
${ }^{382}$ LEITÃO, Luís Manuel Teles de Menezes. As medidas defensivas contra uma oferta pública de aquisição hostil. O Direito. Ano 138, t. III, Coimbra: Almedina, 2006, p. 465.

${ }^{383}$ HANNES, Sharon. The Hidden Virtue of Antitakeover Defenses. Harvard Law School John M. Olin Center for Law, Economics and Business Discussion Paper Series. n. 354, p. 3; 23 e ss, 2002. Disponível em

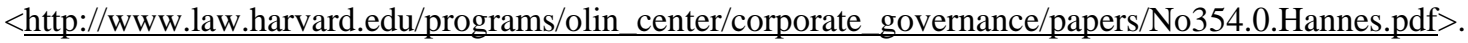
Acesso em 12.12.2009.

${ }^{384}$ John Laide, em estudo específico sobre os efeitos de planos de poison pill no preço de compra de companhias envolvidas em takovers apresenta evidências empíricas de que os acionistas de companhias com mecanismos de poison pills, em geral, receberam valores maiores por suas ações do que aqueles obtidos por acionistas de companhias que não os possuíam (LAIDE, John. Research Spotlight: Poison Pill M\&A Premiums. Nova York, 30.08.2005. Disponível em <http://www.sharkrepellent.net/pub/rs_20050830.html>.
} 
Da mesma forma, há espécies de medidas defensivas, tal como ocorre com o cavaleiro branco (white knight) e o escudeiro branco (white squire), respectivamente examinados nos itens 6.6 e 6.7, em que a companhia-alvo envolve terceiros para realizarem ofertas concorrentes para a aquisição de seu controle. Consequentemente, há majoração do preço de compra das ações de emissão da companhia-alvo.

As discussões doutrinárias sobre os efeitos das medidas defensivas estão longe de serem conclusivas ${ }^{385}$. Baseando-se em evidências empíricas, de um lado, há quem sustente que as medidas defensivas reduzem o valor das ações da companhia-alvo e, até mesmo, diminuem a ocorrência de ofertas públicas ${ }^{386}$. De outro lado, há quem se oponha aos efeitos negativos no valor da companhia e no desempenho desta última por conta da adoção de medidas defensivas ${ }^{387}$.

No que tange à experiência brasileira, bancos e demais assessores financeiros em processos de abertura de capital costumam sustentar que a existência das medidas defensivas tem o efeito de reduzir o valor da oferta na distribuição inicial de ações da companhia $^{388}$.

Acesso em 12.12.2009). No mesmo sentido, reconhecendo que as medidas defensivas elevam o preço de venda das ações: COMMENT, Robert; SCHWERT, G. William. Poison or Placebo? Evidence on the Deterrent and Wealth Effects of Modern Antitakeover Measures. Journal of Financial Economics. 1995. Disponível em SSRN: $<$ http://ssrn.com/abstract=5781>. Acesso em 12.12.2009.

${ }^{385}$ Sobre as críticas aos métodos adotados em estudos empíricos para apurar efeito de aumento ou redução do preço das ações em decorrência da utilização de medidas defensivas, refira-se a COATES IV, John C. Takeover Defenses in the Shadow of the Pill: a critique of the scientific evidence. Texas Law Review. v. 79, n. 2, dez. 2000. Disponível em SSRN: <http://ssrn.com/abstract=263632>. Acesso em 12.12.2009; e Idem. The Contestability of Corporate Control: a critique of the scientific evidence on takeover defenses. Harvard Law and Economics Discussion Paper, n. 265, set. 1999. Disponível em SSRN: $<$ http://ssrn.com/abstract=173628 $>$. Acesso em 12.12.2009.

${ }^{386}$ MALATESTA, Paul H.; WALKLING, Ralph A. Poison Pill Securities: Stockholder Wealth, Profitability, and Ownership Structure. Journal of Financial Economics. v. 20, p. 347-376, 1989. Disponível em SSRN: $<$ http://ssrn.com/abstract=918047 > . Acesso em 12.12.2009.

387 KARPOFF, Jonathan M.; DANIELSON, Morris G. Do Pills Poison Operating Performance?. 07.05.2002. Disponível em SSRN: $<$ http://ssrn.com/abstract=304647>. Acesso em: 12.12.2009.

${ }^{388} \mathrm{O}$ informativo do banco de investimento BTG Pactual, por exemplo, consigna: “We don’t believe poison pills protect minority shareholders' investiment value. If the Fundamentals don't justify a Premium price, all else equal, the transactions, as a general rule, simply don't go ahead. If that's the case, instead of protecting shareholders by increasing the potential upside of stocks, poison pills may be reason for a discount" (JUNQUEIRA, Antonio; SEQUEIRA, Carlos. Poison pills don't increase a stock value. Getting to know Brazil. BTG Pactual, 23.11.2009, p. 1). 
Em uma companhia aberta com ações dispersas no mercado, a possibilidade de tomada de controle, aliada à inexistência de proteções, disciplina os administradores a atuarem eficientemente na gestão da companhia ${ }^{389}$.

Entende-se que as medidas defensivas fazem com que os membros da administração se sintam mais confortáveis e menos ameaçados em seus cargos, uma vez que a probabilidade de serem substituídos é menor, em decorrência da maior estabilidade no exercício do poder de controle ${ }^{390}$.

O risco de que uma oferta hostil venha a ocorrer tem a função de disciplinar os membros da administração para o benefício dos acionistas, uma vez que os administradores tendem a visar à valorização da cotação das ações da companhia, de modo a torná-la menos atrativa às tentativas de tomada de controle ${ }^{391}$.

Lucian Bebchuk, com base na experiência norte-americana, sintetiza que "when managers are protected from takeovers by strong antitakeover statutes or by

${ }^{389}$ CLARK, Robert Charles. Corporate Law. Boston / Toronto: Little, Brown and Company, 1986, p. 535; MANNE, Henry G. Theories and Evidence. Mergers and the Market for Corporate Control. In: ROMANO, Roberta [coord.]. Foundations of Corporate Law. 2. re-imp. Nova York: Foundation Press, 2004, pp.110120; JENSEN, Michael C.; RUBACK, Richard S. The Market for Corporate Control: The Scientific Evidence. In: ROMANO, Roberta [coord.]. Foundations of Corporate Law. 2. re-imp. Nova York: Foundation Press, 2004, pp. 291-322. KINI, Omesh; KRACAW, William; MIAN, Shehzad L. Corporate Takeovers, Firm Performance, and Board Composition. Jul. 1994. Disponível em SSRN: $<$ http://ssrn.com/abstract=5527>. Acesso em 12.12.2009.

${ }^{390}$ HANNES, Sharon. The Hidden Virtue of Antitakeover Defenses. Harvard Law School John M. Olin Center for Law, Economics and Business Discussion Paper Series. n. 354, p. 4, 2002. Disponível em $<$ http://www.law.harvard.edu/programs/olin_center/corporate_governance/papers/No354.0.Hannes.pdf $>$. Acesso em 12.12.2009.

391 "A fundamental premise underlying the market for corporate control is the existence of a high positive correlation between corporate managerial efficiency and the market price of shares of that company. As an existing company is poorly managed - in the sense of not making as great a return for the shareholders as could be accomplished under other feasible managements - the market price of the shares declines relative to the shares of other companies in the same industry or relative to the market as a whole. [...] The lower the stock price, relative to what it could be with more efficient management, the more attractive the takeover becomes to those who believe that they can manage the company more efficiently. And the potential return from the successful takeover and revitalization of a poorly run company can be enormous [...]" (MANNE, Henry G. Op. cit., p. 224). 
antitakeover provisions, managerial slack increases” ${ }^{392}$. A inexistência das medidas defensivas tem o efeito de disciplinar os administradores, para que atuem de modo a evitar que a companhia se coloque vulnerável ao takeover e, consequentemente, sejam tais administradores potencialmente substituídos em seus cargos ${ }^{393}$.

Em contraposição a este reconhecimento de que risco de uma oferta hostil tem a função de disciplinar os membros da administração para o benefício dos acionistas, argumenta-se que a vulnerabilidade às ofertas hostis é uma fraqueza profunda na estrutura de gestão das companhias, pois expõe a dispersão acionária e acionistas não coordenados às táticas de tomada de controle ${ }^{394}$, que, em muitos casos, se utilizam de engrenagens abusivas.

Há, também, quem sustente que a adoção de proteções contra tomada de controle não influencia no desempenho dos administradores da companhia ${ }^{395}$.

\subsection{DESESTÍMULO AO INVESTIMENTO}

Diz-se que as medidas defensivas têm o efeito de desestimular a realização de investimentos da companhia, sob a ótica dos acionistas com perfil de investidores de mercado, que não querem aplicar recursos em companhias dotadas de proteções que podem restringir a circulação de suas ações.

392 BEBCHUK, Lucian A. Why Firms Adopt Antitakeover Arrangements. University of Pennsylvania Law Review, n. 152, pp. 713-753, 2003; Harvard Law and Economics Discussion Paper, n. 420. Disponível em SSRN: $<$ http://ssrn.com/abstract=404200>. Acesso em 12.12.2009.

${ }^{393}$ LEITÃO, Luís Manuel Teles de Menezes. As medidas defensivas contra uma oferta pública de aquisição hostil. O Direito. Ano 138, t. III, Coimbra: Almedina, 2006, p. 465.

394 "Although academic commentators and institutional investors generally believe that hostile tender offers are a useful device for disciplining corporate management, managers themselves believe that vulnerability to hostile bids is a profound weakness in the corporate governance structure because it exposes disaggregated and disorganized shareholders to abusive tender-offer tactics. They argue that they cannot protect shareholders without the tools to defeat inadequate tender offers" (ALLEN, William T.; KRAAKMAN, Reinier. Commentaries and Cases on the Law of Business Organization. Nova York: Aspen Publishers, 2003, p. 505).

395 KARPOFF, Jonathan M.; DANIELSON, Morris G., Do Pills Poison Operating Performance?. 07.05.2002. Disponível em SSRN: <http://ssrn.com/abstract=304647> . Acesso em: 12.12.2009. 
Este efeito está presente especialmente quando adotadas medidas defensivas expressas, cuja existência se torna rapidamente de conhecimento público, tal como aquelas estabelecidas estatutariamente, o que tende a não se verificar - ao menos não na mesma proporção - quando se trata de medidas defensivas menos flagrantes.

Esta implicação ocorre quando o acionista com perfil de investidor de mercado sabe que há um limite de participação acionária que pode deter na companhia, a partir do qual estará obrigado a realizar um grande esforço financeiro, caso pretenda elevá-la. Diante deste cenário, o investidor tende a sentir-se desinteressado em aplicar recursos na companhia, sabendo desde o princípio as limitações impostas ao seu investimento.

\subsection{ENVOLVIMENTO DA AdMINISTRAÇão NA NEGOCIAÇÃo}

As medidas defensivas funcionarão como mecanismo para envolver a administração na negociação da oferta realizada aos acionistas da sociedade visada. Este é o efeito da medida defensiva ao estruturar a negociação da oferta entre o ofertante e os acionistas da companhia-alvo, que estarão representados por seus órgãos de administração.

Há correntes doutrinárias ${ }^{396}$ que sustentam que, independentemente do modelo de alocação do poder-dever de decisão quanto à oferta pública de aquisição de controle realizada para o takeover da companhia-alvo, a administração está obrigada a resistir a ofertas hostis inadequadas. Por outro lado, parte da doutrina entende que a administração

\footnotetext{
${ }^{396}$ Tal corrente é liderada pelo emblemático advogado norte-americano Martin Lipton, com a premissa básica de que maximizar o preço das ações nem sempre é o melhor para a sociedade, a empresa e os próprios acionistas. A este respeito, referir-se a STOUT, Lynn A. Takeovers in the Ivory Tower: How Academics are Learning Martin Lipton May be Right. UCLA School of Law. Law-Econ Research Paper, n. 05-21, set. 2005. Disponível em SSRN: <http://ssrn.com/abstract=803836>. Acesso em 12.12.2009; e LIPTON, Martin; ROWE, Paul K. Pills, Polls, and Professors: A Reply to Professor Gilson. The Delaware Journal of Corporate Law, v. 27, n. 1, pp. 1-55, 2002. Disponível em SSRN: <http://ssrn.com/abstract=398060>. Acesso em 12.12.2009.
} 
não deve se envolver na negociação de tentativas de tomada de controle, devendo o mercado se auto-regular pelas regras de eficiência na alocação de recursos disponíveis ${ }^{397}$.

Independentemente da concepção doutrinária que se adote sobre o tema, a maioria das medidas defensivas existentes tem o efeito de prolongar o processo de tomada de controle e, consequentemente, envolver a administração ou ao menos propiciar meios para que os acionistas da companhia-alvo envolvam a administração nas negociações de tomada de controle.

De certo modo, o envolvimento da administração fortalece mecanismos para a ocorrência de negociação em prol dos acionistas, no sentido de que o ofertante eleve o valor proposto em sua oferta pública. É mais fácil que a administração desempenhe esta função em nome da pluralidade de acionistas em vez de aguardar que o conjunto de acionistas dispersos no mercado se coordene neste sentido ${ }^{398}$. Sob esta ótica, a medida defensiva funciona com um mecanismo eficiente para o aumento do poder de barganha em benefício dos acionistas da companhia-alvo ${ }^{399}$.

Além disto, os administradores dispõem de informações adequadas em relação à companhia. Na maioria dos casos, a administração está em condições melhores do que seus acionistas para julgar os termos e condições da oferta, inclusive quanto à adequação do preço proposto. Sendo assim, o envolvimento da administração pode permitir uma reação mais técnica e estruturada em relação à oferta pública realizada aos acionistas.

\footnotetext{
${ }^{397}$ Em tal corrente, destacam-se, por exemplo, Frank Easterbrook e Daniel Fischel ao sustentarem que a atuação adequada dos membros do Conselho de Administração é manterem-se passivos diante de tentativas de tomada de controle, permitindo que o mercado de capitais se auto-regule e o preço de compra das ações se forme em processo natural de alocação eficiente de recursos (EASTERBROOK, Frank H.; e FISCHEL, Daniel R. The Proper Role of a Target's Management in Responding to a Tender Offer. Harvard Law Review. v. 94, n. 6, pp. 1161-1204, abr. 1981).

${ }^{398}$ Sobre a dificuldade de coordenação dos acionistas diante da existência de uma tentativa de tomada de controle, referir-se a DAVIES, Paul; HOPT, Klaus J. Control Transactions. In: KRAAKMAN, Reinier et al. The Anatomy of Corporate Law: A Comparative and Functional Approach. Oxford: Oxford University Press, 2004, pp. 157-191; e MUCCIARELLI, Federico M. White Knights and Black Knights: Does the Search for Competitive Bids Always Benefit the Shareholders of 'Target' Companies?. 15.06.2006. Disponível em

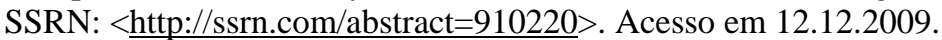

399 SUBRAMANIAN, Guhan. Bargaining in the Shadow of Takeover Defenses. Yale Law Journal. v. 113, n. 3, dez. 2003. Disponível em SSRN: <http://ssrn.com/abstract=442721>. Acesso em 12.12.2009.
} 


\section{PODERES E DEVERES DA ADMINISTRAÇÃO EM RELAÇÃO ÀS MEDIDAS DEFENSIVAS}

Conforme observamos anteriormente, o envolvimento da administração na negociação da oferta realizada aos acionistas é um dos efeitos decorrentes da adoção de medidas defensivas.

Há parâmetros legais a serem observados na atuação da administração diante de tentativa de tomada de controle, os quais se referem à conduta de aceitar, rejeitar e/ou negociar melhores condições para a conclusão da tomada de controle, valendo-se, quando necessário, do emprego efetivo de proteções contra o takeover hostil.

A relação entre os deveres da administração e as defesas é distinta em relação às medidas defensivas preventivas e às posteriores. A liberdade de atuação preventiva dos administradores é muito maior do que a postura que se espera diante da efetiva tentativa de tomada de controle, sendo mais restrita a admissibilidade das medidas defensivas posteriores.

Além disso, na maioria dos casos em que as medidas defensivas são utilizadas de forma preventiva, há uma presunção de envolvimento dos acionistas na decisão de adotar estas defesas e/ou o conhecimento dos acionistas sobre a existência das proteções à época do ingresso destes na companhia.

A atuação dos administradores deve observar os critérios impostos pelos deveres legais diante de tentativas de tomada de controle. Estes mandamentos aplicam-se, também, na utilização de medidas defensivas.

8.1 Modelos de Conduta E Padrões DE REvisão DA ATuAÇão DA AdMinistraçÃo 
A experiência norte-americana desenvolveu, com relação aos poderes e deveres dos administradores em operações de tomada de controle, de um lado, os modelos de conduta (models of conduct) e, de outro lado, os padrões de revisão (standards of review).

Os modelos de conduta (models of conduct) são recomendações de arquétipos de atuação dos administradores diante de tentativas de tomada de controle, os quais foram formulados, basicamente, após a apreciação pelos tribunais norte-americanos de casos paradigmáticos envolvendo tentativas de tomada de controle. Os modelos de conduta (models of conduct) são formulações de deveres gerais que impõem uma prestação, ativa ou omissiva, aos administradores, diante de potencial tomada de controle da companhia.

Os deveres gerais que integram os modelos de conduta (models of conduct) compreendem aqueles contidos no amplo conceito dos deveres fiduciários ${ }^{400}$. Os deveres gerais possuem delineamento flexível, amoldando-se especificamente em cada caso concreto em vistas ao cumprimento das atribuições dos administradores ${ }^{401}$.

Os padrões de revisão (standards of review), por sua vez, funcionam como arrimos a serem utilizados pelos tribunais com relação à interpretação de casos envolvendo tomadas de controle, e têm evoluído recentemente nos EUA ${ }^{402}$.

Originalmente, tais padrões de revisão referiam-se basicamente aos métodos de: (i) justiça integral (entire fairness), que consistia em artifício extremamente rigoroso adotado pelos tribunais para a análise da atuação dos administradores diante de tentativas de tomada de controle; (ii) regra do julgamento do negócio (business judgment rule), que consistia em reconhecer que, respeitadas determinadas premissas na atuação do administrador $^{403}$, o Poder Judiciário não pode intervir nas decisões de mérito gerencial e de

\footnotetext{
${ }^{400}$ Os deveres fiduciários (fiduciary duties) estão examinados em maiores detalhes no item 8.4 deste trabalho.

${ }^{401}$ Os tribunais norte-americanos, em decisão recente, reconheceram a flexibilidade dos deveres gerais dos administradores de companhias, no caso Lyondell Walter E. Ryan, Jr. v. Lyondell Chemical Company, et al (C.A. n. 3176-VCN, Delaware, 2008, Rel. John W. Noble), em que a Suprema Corte de Delaware consignou que "[n]o court can tell directors exactly how to accomplish their goal, because they will be facing a unique combination of circumstances, many of which will be outside their control. As we noted in Barkan v. Amsted Industries, Inc 'there is no single blueprint that a board must follow to fulfill its duties'”.

${ }^{402}$ Para maiores informações, referir-se a ALLEN, William T.; JACOBS, Jack B.; STRINE JR., Leo E. Function over Form: a reassessment of standards of review in Delaware Corporation Law. The Business Lawyer, n. 56, p. 3, 2001. Disponível em < www.westlaw.com>. Acesso em 12.12.2009.

${ }^{403}$ A regra do julgamento do negócio (business judgment rule) está examinada em maiores detalhes no item 8.5 deste trabalho.
} 
administração empresarial adotadas pelos administradores das companhias; e (iii) violação de deveres fiduciários (fiduciary duties violation), em concepção ampla deste último, que consistia em examinar se o comportamento dos administradores de companhias norteamericanas atendia aos preceitos dos deveres fiduciários que lhes são impostos.

A doutrina recente nos EUA, liderada por alguns dos principais expoentes dos tribunais do Estado de Delaware, vem propondo a revisão de tais padrões de revisão (standards of review), sugerindo um recenseamento em três protótipos básicos que tornariam mais eficiente a aplicação dos deveres da administração naquele país, conforme lecionam Willian T. Allen, Jack Jacobs e Leo Strine Jr.:

[...] the corporation law can function most effectively with three basic standards of judicial review: (i) a gross negligence standard of review for claims that directors are liable for damages caused by their inattention - a standard that would require a plaintiff to prove both a breach of the duty and the fact and extent of any damages caused by the breach; (ii) a rehabilitated entire fairness standard to address duty of loyalty claims; and (iii) an intermediate standard of review to govern challenges to director decisions arguably influenced by an entrenchment motive, e.g., the adoption of antitakeover defensive measures or the approval of a change of control ${ }^{404}$.

É importante que se conheçam entre nós as propostas de recenseamento que vêm ocorrendo nos EUA, em relação aos padrões de revisão (standards of review), de modo a evitar a importação no Brasil de conceitos superados na prática estrangeira.

É nesta medida que propomos um cuidado maior com a utilização da regra do julgamento do negócio (business judgment rule), como excludente de responsabilidade dos administradores, no equilíbrio existente entre o cumprimento dos deveres fiduciários (fiduciary duties) e as excludentes de responsabilidade suscitadas pela aplicação da regra do julgamento do negócio (business judgment rule).

A interpretação das matérias pelos tribunais norte-americanos é fonte de valiosa orientação quanto à atuação dos administradores em tomadas de controle,

${ }^{404}$ ALLEN, William T.; JACOBS, Jack B.; STRINE JR., Leo E. Function over Form: A Reassessment of Standards of Review in Delaware Corporation Law. The Business Lawyer, n. 56, 2001, p. 3. 
especialmente diante da inexistência de volume de casos concretos no Brasil expondo o tratamento do tema na prática. Entretanto, tratando-se de fonte inspirada em realidade jurídica diferente da nossa, são necessários cuidados para evitar a importação de padrões estrangeiros incompatíveis com o nosso sistema jurídico.

\subsection{CAsos PARAdigmáticos nOS Estados Unidos da AMÉRICA}

Conforme exposição histórica constante do item 4.2, as tomadas de controle tornaram-se frequentes nos EUA a partir da década de 1960, tendo este movimento encontrado o seu ápice durante a década de 1980.

Os tribunais norte-americanos analisavam casos de atuação da administração em operações de tomada de controle com base nos mesmos critérios adotados em qualquer outra questão societária ${ }^{405}$. Caso se julgasse que a administração atuou com interesse pessoal e/ou de terceiros, os administradores estariam obrigados a demonstrar que atuaram de forma adequada, pautados em princípios e deveres da administração.

Essa abordagem revelava-se ineficiente, diante do reconhecimento de que os administradores não são propriamente desinteressados em relação aos processos de tomada de controle, uma vez que têm interesse particular na repercussão que tal movimento societário terá na esfera de sua vida pessoal. Portanto, os parâmetros de análise da questão devem ser específicos, não lhes sendo aplicáveis critérios genéricos.

A interpretação dos tribunais norte-americanos, especialmente em Delaware, evoluiu de forma marcante e tais casos passaram a ser abordados levando-se em conta as complexidades envolvidas nas disputas pelo controle em companhias dotadas de dispersão acionária.

\footnotetext{
${ }^{405}$ William T. Allen e Reinier Kraakman ensinam que “courts reviewed the board's response to a contest for control just as they would review any other corporate action” (ALLEN, William T.; KRAAKMAN, Reinier. Commentaries and Cases on the Law of Business Organization. Nova York: Aspen Publishers, 2003, p. 499).
} 
Alguns importantes casos paradigmáticos submetidos aos tribunais norteamericanos, mais precisamente em Delaware, são reconhecidos como responsáveis por influenciar a interpretação dos poderes e deveres da administração diante de potenciais tomadas de controle, auxiliando na formulação dos modelos de conduta (models of conduct) e dos padrões de revisão (standards of review).

As decisões de Delaware, em matéria de takeover, são usualmente adotadas como referência nos EUA ${ }^{406}$. A interpretação de tais casos pode ter influência não apenas nos EUA, como também em outros países, desde que submetida aos balanceamentos necessários para a adequação aos ordenamentos jurídicos de cada país.

A riqueza da jurisprudência norte-americana em tópicos relacionados às tomadas de controle e às defesas contra tais ameaças é tão grande, que poderia instigar uma imersão profunda e sem fim nas experiências existentes naquele país. Porém, como a nossa proposta não é seguir estrangeirismos, mas sim utilizar a experiência internacional em casos notáveis, naquilo que tais casos possam contribuir à experiência pátria, optamos por restringir nossa análise aos casos a seguir, reconhecendo a existência de inúmeros outros que também poderiam ser referidos nesta ocasião.

\subsubsection{SMITH V. VAN GORKOM}

Dentre tais casos paradigmáticos submetidos à Suprema Corte de Delaware, destaca-se, inicialmente, o Smith v. Van Gorkom ${ }^{407}{ }^{408}$, decorrente de uma operação

\footnotetext{
${ }^{406}$ Martin Lipton e Paul Rowe ensinam que o American Law Institute adotou as decisões de Delaware sobre takeover como modelo para todos os EUA (LIPTON, Martin; ROWE, Paul K. Pills, Polls and Professors: A Reply to Professor Gilson. NYU Center for Law and Business Research Paper, n. 01-006, abr. 2001. Disponível em SSRN: $<\underline{\text { http://ssrn.com/abstract }=268520}>$. Acesso em 12.12.2009.

${ }^{407}$ Smith v. Van Gorkom (488 A.2d 858, Delaware, 1985, Rel. Henry R. Horsey).

${ }^{408}$ Para um exame cuidadoso e detalhado do caso Smith v. Van Gorkom (488 A.2d 858, Delaware, 1985, Rel. Henry R. Horsey), referir-se a SILVA, Alexandre Couto. Responsabilidade dos Administradores de S/A: Business Judgment Rule. Rio de Janeiro: Elsevier, 2007, pp. 149-156, em que o autor examina o caso com especial atenção aos critérios que absolveriam os administradores, mediante a aplicação da regra do julgamento do negócio (business judgement rule).
} 
societária amigável de aquisição da companhia aberta, norte-americana, Trans Union Corporation (“Trans Union”).

Referida operação de aquisição se daria em duas etapas, sendo a primeira delas uma oferta pública, e a segunda, uma incorporação da Trans Union por outra sociedade ligada ao possível adquirente do controle, em sistemática clássica do two-tier takeover, tão comum nos EUA, especialmente durante a década de 1980.

A operação havia sido concebida amigavelmente pelos administradores da Trans Union, interessados em realizar a venda do controle da companhia, e liderados pelo Diretor Presidente, Sr. Jerome Van Gorkom, que contactaram Jay Pritzker, empresário de renome, frequentemente envolvido em operações de tomada de controle à época.

Os acionistas da Trans Union, insatisfeitos com a atuação dos administradores em tal operação, acionaram-nos judicialmente, sob a argumentação de que haviam agido de forma negligente, ao deixarem de se informar adequadamente para tomar uma decisão e de investigar se poderia ser obtido um preço mais elevado para a realização da operação.

Em Smith v. Van Gorkom, os tribunais norte-americanos de Delaware julgaram que os membros do Conselho de Administração da Trans Union eram pessoalmente responsáveis por sua decisão de aprovar a operação societária, que o tribunal considerou ter sido tomada com desconhecimento indesculpável, por negligência (gross negligence).

William Allen e Reinier Kraakman ${ }^{409}$, examinando o caso, ponderam que as circunstâncias em que os membros da administração foram condenados poderiam ser interpretadas de forma a reconhecer o cumprimento dos deveres de tais administradores em outras situações, ao terem participado de todas as reuniões e deliberado sobre decisões estratégicas em relação à pretendida operação.

Entretanto, os próprios William Allen e Reinier Kraakman ${ }^{410}$ expõem que casos posteriores demonstrariam que os tribunais de Delaware haviam iniciado um esforço

\footnotetext{
${ }^{409}$ ALLEN, William T.; KRAAKMAN, Reinier. Commentaries and Cases on the Law of Business Organization. Nova York: Aspen Publishers, 2003, pp. 498-499.

${ }^{410}$ Ibid., pp. 498-499.
} 
de redefinição do modelo de conduta (model of conduct) dos membros da administração de companhias abertas em aquisições de controle.

\subsubsection{Unocal Corp. V. Mesa Petroleum Co.}

No caso paradigmático Unocal Corp. v. Mesa Petroleum Co ${ }^{411}$, submetido à Suprema Corte de Delaware, examinaram-se os esforços dos membros do Conselho de Administração da Unocal Corp. (“Unocal”) em defenderem a companhia de uma oferta pública para tomada hostil de seu controle.

O caso resultou da tentativa de tomada de controle pela Mesa Petroleum Co. ("Mesa Petroleum”), acionista detentora de aproximadamente $13 \%$ do capital social da Unocal, que propôs oferta pública para aquisição de ações representativas de aproximadamente $37 \%$ do capital social da Unocal pelo valor de US\$ 54,00 por ação. Subsequentemente à oferta pública, as demais ações remanescentes dispersas no mercado acionário seriam retiradas de circulação, por meio de permuta pela Mesa Petroleum, como acionista controladora da Unocal, sendo que por tais ações a serem retiradas de circulação seria pago com outros valores mobiliários a serem permutados, com valor correspondente a US\$ 54,00 por ação. Pretendia-se adotar, também neste caso, a abusiva two-tier takeover, comumente utilizada nos EUA durante a década de 1980.

Em momento posterior, a Mesa Petroleum foi obrigada, por determinações judiciais, a divulgar as características dos valores mobiliários que seriam oferecidos em substituição às demais ações dispersas no mercado, que não aderissem à oferta pública, no âmbito da segunda etapa da tomada de controle. Consequentemente, a Mesa Petroleum divulgou que seriam utilizados títulos de dívida altamente subordinados (junk bonds), como forma de pagamento ${ }^{412}$.

${ }^{411}$ Unocal v. Mesa Petroleum (493 A.2d 946, Delaware, 1985, Rel. Andrew G. T. Moore).

${ }^{412}$ MOORE, Andrew G.T. The Birth of Unocal: A Brief History. Delaware Journal of Coporate Law. v. 31, n. 3, pp. 865-886, 2006, p. 873. Disponível em: <http://ssrn.com/abstract=946018>. Acesso em: 12.12.2009. 
Os administradores da Unocal conceberam estratégias de defesa contra a anunciada tentativa de tomada de controle e, em paralelo, realizaram inúmeros estudos que constataram que o valor de mercado por ação da Unocal seria substancialmente superior aos US\$ 54,00 propostos pela Mesa Petroleum. Além disso, os administradores da Unocal concluíram que os junk bonds a serem oferecidos em substituição às ações dispersas no mercado da Unocal, que seriam resgatadas, tal como anunciado pela Mesa Petroleum, tinham valor substancialmente inferior ao preço de US\$ 54,00 por ação, adotado como referência para tal substituição.

Os administradores da Unocal entenderam estar diante de uma coercitiva twotier tender offer empreendida pela Mesa Petroleum, tendo rejeitado por unanimidade a operação proposta.

Em seguida, os administradores da Unocal, aconselhados por assessores financeiros, realizaram oferta pública de recompra, para a aquisição de suas próprias ações, em quantidade correspondente a, aproximadamente, 29\% do capital social da Unocal, tendo excetuado do âmbito de tais ações aquelas detidas ou recém-adquiridas pela Mesa Petroleum.

A administração da Unocal propôs aos acionistas o pagamento do valor correspondente a US\$ 72,00 por ação, a ser quitado com títulos de dívida, que elevariam o nível de endividamento da companhia, (i) tornando-a menos atrativa a tentativas de tomada de controle em geral; e (ii) inviabilizando a condução das operações de perfuração de poços de petróleo realizadas pela Unocal, que eram o principal ativo de interesse da Mesa Petroleum ${ }^{413}$.

A oferta pública para aquisição de suas próprias ações, realizada de forma seletiva, com exclusão da Mesa Petroleum, suscitou inúmeras controvérsias e discussões acerca da violação, pelos administradores da Unocal, de seus deveres fiduciários ao tratarem de forma distinta os acionistas da companhia em relação à oferta pública realizada.

\footnotetext{
${ }^{413}$ Por razões fáticas da Unocal, seus demais negócios e o próprio empreendimento em si permaneceria viável, ainda que restringindo a atividade de perfuração de poços de petróleo.
} 
Entretanto, os tribunais de Delaware entenderam que os administradores haviam atuado com os poderes que lhes haviam sido atribuídos pela lei, utilizando seus deveres e responsabilidades em respeito aos negócios e assuntos da companhia. A legislação societária de Delaware autorizava a negociação com as próprias ações, com o reconhecimento de que em determinados casos os administradores podem negociar seletivamente ${ }^{414}$ com as ações de emissão da companhia, desde que não o façam com o interesse, próprio ou exclusivo, de entrincheirarem-se em seus cargos na administração ${ }^{415}$.

A análise escorou-se nas premissas desenvolvidas a partir do caso Cheff $v$. Mathes $^{416}$, examinado no item 8.2.6, que rejeita a atuação da administração destinada a adotar medidas defensivas como forma de entrincheirar-se no cargo.

A doutrina norte-americana refere-se, ainda, ao caso Unocal $v$. Mesa Petroleum como o precedente para o desenvolvimento do padrão de revisão (standards of review) intermediário entre a regra de julgamento do negócio (business judgement rule), entendida como forma permissiva de interpretação pelos tribunais da atuação da administração diante de tentativas de tomada de controle; e a regra de justiça integral (entire fairness), entendida como extremamente rigorosa na análise da atuação dos administradores diante de tentativas de tomada de controle ${ }^{417}$.

\footnotetext{
${ }^{414}$ Alexandre Couto Silva aponta que "após a decisão do caso Unocal, a Securities and Exchange Comission (SEC) adotou a regra 14 d-10 do Williams Act, conhecida como a all holders rule que proíbe a recompra de ações de forma seletiva, exigindo tratamento igual para todos os acionistas da mesma classe" (SILVA, Alexandre Couto. Responsabilidade dos Administradores de S/A: Business Judgment Rule. Rio de Janeiro: Elsevier, 2007, p. 216).

${ }^{415}$ Extrai-se, como substrato, o seguinte trecho do julgamento do caso Unocal v. Mesa Petroleum (493 A.2d 946, Delaware, 1985, Rel. Andrew G. T. Moore) de enorme relevância ao estudo das medidas defensivas: "The board has a large reservoir of authority upon which to draw. Its duties and responsibilities proceed from the inherent powers conferred by 8 Del. C. $\$ 141$ (a), respecting management of the corporation's business and affairs. Additionally, the powers here being exercised derive from 8 Del. C. §160 (a), conferring broad authority upon a corporation to deal in its own stock. From this it is now well established that in the acquisition of its shares a Delaware corporation may deal selectively with its stockholders, provided the directors have not acted out of a sole or primary purpose to entrench themselves in office" (Cheff v. Mathes 199 A.2d 548, Delaware, 1964, Rel. James B. Carey).

${ }^{416}$ Cheff v. Mathes (199 A.2d 548, Delaware, 1964, Rel. James B. Carey).

${ }^{417}$ ALLEN, William T.; KRAAKMAN, Reinier. Commentaries and Cases on the Law of Business Organization. Nova York: Aspen Publishers, 2003, pp. 498-499.
} 
O julgamento do caso Unocal $v$. Mesa Petroleum formulou o modelo de conduta (model of conduct) Unocal, também referido coloquialmente como os "Deveres Unocal ${ }^{418}$.

Com base no modelo de conduta (model of conduct) referido como "Dever Unocal”, formulou-se a recomendação de que, diante de tentativas de tomada de controle, os administradores devem analisar se a mesma é uma ameaça aos negócios da companhia e, se assim for, adotar medidas defensivas proporcionais à ameaça representada pela tentativa de tomada de controle.

O Conselho de Administração da companhia não deve ser passivo diante de uma tomada de controle hostil. Ao contrário, tal órgão social deve atuar como o defensor do metafórico bastião medieval societário e protetor dos acionistas da companhia ${ }^{419}$. Deste posicionamento da Suprema Corte de Delaware no Unocal v. Mesa Petroleum se fortaleceu o entendimento de que o Conselho de Administração está imbuído de uma função de proteção (gatekeeping function) em circunstâncias hostis de tomada de controle.

\section{REVLON V. MACANDREWS AND FORBES HOLDINGS, INC.}

Outro caso paradigmático submetido à Suprema Corte de Delaware foi o Revlon v. MacAndrews and Forbes Holdings, Inc. ${ }^{420}$.

\footnotetext{
${ }^{418}$ Os "Deveres Unocal" foram depois aperfeiçoados com decisões supervenientes de Delaware nos casos Paramount Communications, Inc. \& KDS Acquisitions Corp. v. Time, Inc. et al. (571 A.2d 1140, Delaware, 1989, Rel. Henry R. Horsey); Paramount Communications, Inc. v. QVC Network, Inc. (637 A.2d 34, Delaware, 1994, Rel. E. Normal Veasey) e Unitrin, Inc. v. American General Corp. (651 A.2d 1361, Delaware, 1995, Rel. Randy J. Holland).

${ }^{419}$ Conforme decidido pela Suprema Corte de Delaware, em Unocal v. Mesa Petroleum Co. (493 A.2d 946, Delaware, 1985, Rel. Andrew G. T. Moore), o Conselho de Administração da companhia-alvo permanece "the defender of the metaphorical medieval corporate bastion and the protector of corporation's shareholders", como bem lembra Bainbridge (BAINBRIDGE, Stephen M. Unocal at 20: Director Primacy in Corporate Takeovers. Law \& Economics Research Papers Series. UCLA School of Law. Law-Econ Research Paper n. 05-19, p. 4, set. 2005. Disponível em $<$ http://papers.ssrn.com/sol3/papers.cfm?abstract id=796224>. Acesso em 12.12.2009).

${ }^{420}$ Revlon v. MacAndrews and Forbes Holdings, Inc. (506. A.2d 173, Delaware, 1986, Rel. Andrew G. T. Moore).
} 
Em apertada síntese, pode-se dizer que o caso Revlon v. MacAndrews and Forbes versou sobre medidas adotadas pela administração da companhia-alvo, envolvendo um cavaleiro branco (white knight) na disputa pelo controle da companhia, de modo a que este realizasse uma oferta pública concorrente, evitando que o controle fosse adquirido pelo potencial adquirente indesejado pelos administradores da companhia-alvo.

Em breve lineamento dos fatos, o grupo Pantry Pride desejava adquirir a Revlon, sendo que nos estágios iniciais da batalha que se travou, o Conselho de Administração da Revlon ${ }^{421}$ havia rejeitado uma oferta do Pantry Pride de US\$45,00 por ação da Revlon, por reputá-la inadequada. Pantry Pride demonstrava fôlego para novas ostensivas, visando a tomar o controle da Revlon e, em razão disto, esta última colocou em prática um plano de poison pill e anunciou um programa de recompra de suas ações.

Concomitantemente à utilização de tais defesas, a administração da Revlon procurou um cavaleiro branco interessado em adquirir o controle da Revlon, tendo localizado o Forstmann Little, especialista em operações de tomada de controle nos EUA.

Com o prosseguimento de ofensivas do Pantry Pride, o Forstmann Little realizou oferta concorrente tendo por objeto ações representativas do controle da Revlon. Pantry Pride e Forstmann Little começaram a sobrepor ofertas um ao outro, em leilão que elevava cada vez mais as cotações das ações da Revlon, até que o Conselho de Administração da companhia-alvo aprovou uma proposta do Forstmann Little de US\$57,25 por ação, contra uma proposta do Pantry Pride de US\$56,25 ${ }^{422}$.

\footnotetext{
${ }^{421}$ Havia na Revlon medidas defensivas preventivas, inclusive plano de poison pill, que determinavam o envolvimento do Conselho de Administração nas negociações em caso de operações de tomada de controle. ${ }^{422}$ A razão pela qual o Conselho de Administração da Revlon aceitou a proposta do Forstmann Little não se relacionava tão-somente ao preço proposto na oferta. Com o objetivo de encerrar tal batalha e assegurar que o controle seria adquirido pelo proponente alinhado à administração, o Conselho de Administração da Revlon atribuiu inúmeras vantagens ao Forstmann Little, que foram determinantes à conclusão da tomada de controle por este último. O Forstmann Little recebeu uma opção de compra de valiosos ativos da Relvon (jóias da coroa, em tradução à expressão em inglês crown jewel), sendo-lhe facultado duas subsidiárias estratégicas da Revlon por preço reconhecidamente abaixo de seu valor de mercado, com previsão de que tal opção de compra se tornava efetiva caso alguém adquirisse $40 \%$ da Revlon. Além disso, Revlon pactuou com Forstmann Little termos em que se implementaria tal operação, outorgando exclusividade ao Forstmann Little para negociações envolvendo o controle da Revlon, pactuando, inclusive, uma multa de aproximadamente US\$ 25.000.000,00 (vinte e cinco milhões de dólares), que deveria ser paga ao Forstmann Little na hipótese a Revlon desistir do negócio.
} 
Em princípio, tal decisão da administração revelava-se adequada, ao buscar um terceiro interessado no controle, visando a elevar o valor pelo qual eventual operação de tomada de controle seria efetuada.

Entretanto, ao examinar o caso Revlon v. MacAndrews and Forbes, os tribunais norte-americanos entenderam que os administradores da Revlon haviam atuado de forma inadequada, ao proporcionarem ao Forstmann Little vantagens desiguais, que desequilibravam a disputa pelo controle da Revlon, revelando postura flagrantemente tendente a favorecer a tomada do controle pelo Forstmann Little $e^{423}$.

Os tribunais norte-americanos entenderam que a aceitação da proposta do Fortsmann Little tinha ocorrido não por conta do valor proposto, mas sim para evitar consequências negativas à Revlon, que haviam sido previamente acordadas com o Fortsmann Little. A aceitação da proposta do Fortsmann Little encerrou disputas que poderiam ter elevado ainda mais os valores de cotação das ações da Revlon.

O julgamento do caso Revlon v. MacAndrews and Forbes formulou o modelo de conduta (model of conduct) Revlon, também referido coloquialmente como os "Deveres Revlon"424, com o mandamento de que o Conselho de Administração "must perform its fiduciary duties in the service of a specific objective: maximizing the sale price of the enterprise" $^{\text {425 }}$.

Resumidamente, as recomendações decorrentes do modelo de conduta resultante do caso Revlon v. MacAndrews and Forbes são as seguintes: (i) a administração

\footnotetext{
${ }^{423}$ William T. Allen e Reinier Kraakman ensinam que mesmo anteriormente ao Revlon v. MacAndrews and Forbes Holdings, Inc. (506. A.2d 173, Delaware, 1986, Rel. Andrew G. T. Moore) a Suprema Corte de Delaware já havia demonstrado preocupações em administradores favorecerem um preferível ofertante, no caso Smith v. Van Gorkom (488 A.2d 858, Delaware, 1985, Rel. Henry R. Horsey). (ALLEN, William T.; KRAAKMAN, Reinier. Commentaries and Cases on the Law of Business Organization. Nova York: Aspen Publishers, 2003, p. 513).

${ }^{424}$ Da mesma forma que os “Deveres Unocal”, os "Deveres Revlon" também foram aperfeiçoados por decisões supervenientes de Delaware, tal como nos casos Paramount Communications, Inc. \& KDS Acquisitions Corp. v. Time, Inc. et al. (571 A.2d 1140, Delaware, 1989, Rel. Henry R. Horsey); Paramount Communications, Inc. v. QVC Network, Inc. (637 A.2d 34, Delaware, 1994, Rel. E. Normal Veasey) e Unitrin, Inc. v. American General Corp. (651 A.2d 1361, Delaware, 1995, Rel. Randy J. Holland), e tal como modelos de conduta flexíveis estão em constante aperfeiçoamento, conforme demonstram as interpretações recentes nos casos In re Walt Disney Co. Deriv. Litigation (906 A 2.d 27, Delaware, Rel. William B. Chandler) e Walter E. Ryan, Jr. v. Lyondell Chemical Company, et al (C.A. n. 3176-VCN, Delaware, 2008, Rel. John W. Noble).

${ }^{425}$ Revlon v. MacAndrews and Forbes Holdings, Inc. (506. A.2d 173, Delaware, 1986, Rel. Andrew G. T. Moore).
} 
da companhia-alvo deve procurar tratar igualmente os ofertantes interessados em adquirir o controle desta última; (ii) caso a administração reconheça que a tomada do controle da companhia é inevitável ou entenda que tal tomada do controle pode ser saudável, as medidas defensivas para proteção contra a tomada de controle só devem ser utilizadas em caráter excepcional; (iii) a administração deve sempre buscar o melhor preço de venda possível aos acionistas para a concretização da operação, quando a tomada de controle se tornar eminente ${ }^{426}$; e (iv) a escolha final dentre as ofertas realizadas deve competir aos acionistas, embora a administração deva atuar nas negociações buscando sempre os melhores termos e condições possíveis para eles.

A identificação dos casos em que os “Deveres Revlon” são aplicáveis é um dos principais desafios pertinentes à matéria dos modelos de conduta (models of conduct) da administração das companhias em relação às tomadas de controle.

Os tribunais norte-americanos têm fixado entendimento de que os "Deveres Revlon” não são aplicáveis a qualquer operação possivelmente envolvendo tomada de controle $^{427}$, mas apenas àquelas realizadas por iniciativa da administração da companhiaalvo e àquelas decorrentes de oferta pública hostil, que resultem em mudança de controle ${ }^{428}$.

A este respeito, destaque-se o recente e emblemático caso Walter E. Ryan, Jr. v. Lyondell Chemical Company, et al ${ }^{429}$, em que a Suprema Corte de Delaware entendeu

\footnotetext{
${ }^{426} \mathrm{Na}$ esteira de aplicação do entendimento manifestado no caso Revlon v. MacAndrews and Forbes Holdings, Inc. (506. A.2d 173, Delaware, 1986, Rel. Andrew G. T. Moore), colocaram-se inúmeros outros casos semelhantes em que, diante do reconhecimento de que o takeover seria inevitável, a atuação da administração deveria ser pautada pelo objetivo de maximizar o preço de venda das ações. Alguns exemplos apontados pela doutrina norte-americana são: Mills Acquisition Co. v. Macmillan, Inc. (559 A.2d 1261, Delaware, 1989, Rel. Andrew G. T. Moore) e Ivanhoe Partners v. Newmont Mining Corp. (535 A.2d 1334, Delaware, 1987). Para maiores informações, referir-se a CHOPER, Jesse H.; COFFEE Jr., John C.; e GILSON, Ronald J. Cases and materials on corporations. 7. ed. Nova York: Aspen Publishers, 2008, especialmente pp. 1003-1006.

${ }^{427}$ Cf. Paramount Communications, Inc. \& KDS Acquisitions Corp. v. Time, Inc. et al. (571 A.2d 1140, Delaware, 1989, Rel. Henry R. Horsey).

${ }^{428}$ Cf. In re Santa Fe Pac. Corp. Shareholder Litigation (669 A.2d 59, Delaware, 1995, Rel. E. Normal Veasey).

${ }^{429}$ C.A. n. 3176-VCN, Delaware, 2008, Rel. John W. Noble. Em abril de 2006, a Basell AF (“Basell”), uma companhia fechada de Luxemburgo, manifestou interesse em adquirir o controle da Lyondell Chemical Company ("Lyondell”), uma companhia aberta norte-americana. Alguns meses depois, a Basell realizou uma oferta propondo-se a adquirir cada ação da Lyondell por \$26,50-28,50. A proposta foi rejeitada, por considera-se baixo o preço proposto. Em maio de 2007, a Basell anunciou publicamente que tinha o direito de adquirir um bloco de ações da Lyondell (i.e., 8,3\%) detidas pelo acionista Occidental Petroleum
} 
que os “Deveres Revlon” não eram aplicáveis à operação, consequentemente isentando os administradores da Lyondell da responsabilidade que os acionistas de tal companhia pretendiam lhes imputar, por violação de deveres fiduciários. Resumidamente, os acionistas da Lyondell argumentavam que os administradores falharam ao não negociarem melhores termos e condições para a operação e/ou buscarem ofertas concorrentes potencialmente superiores àquela que resultou na aquisição do controle da Lyondell pela Basell $A F^{430}$.

\subsubsection{PARAMount Communications, InC. V. Time, INC}

Outro caso paradigmático submetido à Suprema Corte de Delaware foi o Paramount Communications, Inc. v. Time, Inc ${ }^{431}$, que Reiner Kraakman e William Allen consideram que talvez tenha sido a mais famosa tentativa de takeover na década de 1980.

Em breve resumo dos fatos, pode-se relatar que a Time, Inc. (“Time”), em sua estratégia de expandir os negócios em que atuava, passando de editora para uma companhia atuante de forma diversificada no setor de mídia e entretenimento, estava

Corporation e comunicou interesse em outras operações envolvendo a Lyondell. Os membros do Conselho de Administração da Lyondell reuniram-se imediatamente, reconhecendo que estavam diante de um direito efetivo para aquisição de tal bloco de ações (in play), optando por aguardar e observar o que ocorreria (wait and see approach). Algumas companhias de private equity ofereceram aos administradores da Lyondell estruturas para realização de MBOs da Lyondell, mas as propostas foram rejeitadas. Em seguida, após tentativas frustradas de adquirir concorrentes da Lyondell, a Basell realizou em julho de 2007 uma oferta pública de US\$ 40,00 por ação da Lyondell. Entretanto, tal oferta foi recusada e, após rodadas de negociações, a Basell propôs aumentos em sua proposta pelas ações da Lyondell, sem êxito. Entre 12 de Julho e 15 de Julho de 2007, com auxílio de assessores jurídicos e financeiros, a Basell e a administração da Lyondell negociaram os termos de uma potencial incorporação desta última pela Basell, acordando a operação, com bases de US\$ 48 por ação da Lyondell em um excelente preço, conforme apontado pelos assessores que o julgaram "an absolute home run”. Entretanto, acionistas submeteram tal operação aos tribunais norte-americanos (Texas e Delaware), entendendo que os administradores haviam violado deveres fiduciários ao não buscaram melhores condições para a operação. Para maiores informações, referir-se a BARNETT, Rachel J.; MICHELETTI, Edward B., WELCH, Edward P. Victory for Lyondell: Delaware Supreme Court reaffirms there is no single blueprint for following Revlon Duties. The M\&A Lawyer. v. 13, mai. 2009. Disponível em < http://www.skadden.com/content/Publications/Publications1764_0.pdf $>$. Acesso em 12.12.2009.

${ }^{430}$ A Suprema Corte de Delaware reformou a decisão que havia sido proferida em primeira instância, no caso, que havia imposto os "Deveres Revlon” aos administradores do Lyondell.

${ }^{431}$ Paramount Communications, Inc. \& KDS Acquisitions Corp. v. Time, Inc. et al. (571 A.2d 1140, Delaware, 1989, Rel. Henry R. Horsey). 
negociando com a administração da Warner Communications ("Warner") a incorporação desta última pela Time. A reação inicial do mercado em relação à possibilidade de realização da operação valorizou a cotação dos valores mobiliários da Time e da Warner.

Entretanto, durante as tratativas da incorporação, a Paramount Communications, Inc. ("Paramount”) lançou uma oferta pública para a aquisição das ações de emissão da Time ${ }^{432}$, condicionando tal oferta pública a determinadas premissas ${ }^{433}$. A reação do mercado diante de tal oferta pública foi ainda melhor do que havia sido na perspectiva da incorporação da Warner pela Time, pois os acionistas poderiam realizar imediatamente o valor correspondente aos seus investimentos.

Contudo, com olhos fitos em frustrar a tentativa da Paramount e receosa de que não mais conseguiria realizar a operação de incorporação da Warner pela Time, uma vez que tal incorporação exigiria a aprovação majoritária dos acionistas da Time, que se revelavam tendentes à observar a oferta pública da Paramount, a administração da Time substituiu seu plano original de incorporar a Warner por uma oferta pública de aquisição das ações da Warner.

A oferta pública inclusive tornaria a Time menos atrativa à aquisição pela Paramount, uma vez que a Time se tornaria uma companhia muito grande e excessivamente endividada, pela captação dos recursos necessários à oferta pública para a aquisição do controle da Warner. Com isto, a Time deixava de ser um alvo atrativo para a

\section{Paramount.}

${ }^{432}$ A Time possuía estrutura de capital com dispersão acionária, mas dispunha de inúmeros mecanismos de defesa contra tentativas de tomada de controle. A este respeito, Jesse Choper, John Coffee Jr. e Ronald Gilson noticiam que a Time estava equipada com um "arsenal completo" de medidas defensivas, que incluía um plano de poison pill recém-alterado pela Time, em relação ao qual, qualquer aquisição de participação acionária igual ou superior a $15 \%$ da Time, dispararia a utilização de tal plano de poison pill como instrumento de defesa (CHOPER, Jesse H.; COFFEE Jr., John C.; e GILSON, Ronald J. Cases and materials on corporations. 7. ed. Nova York: Aspen Publishers, 2008, p. 966).

${ }^{433}$ De acordo com Jesse Choper, John Coffee Jr. e Ronald Gilson, "Paramount's offer was subject to a number of conditions, the most pertinent of which were the following: (i) termination of the Time-Warner merger agreement (or the agreement being left subject to a vote in which Paramount controlled 51\% of the vote); (ii) termination or invalidation of the share exchange Agreement under circumstances in which there would be no liability to Time; (iii) Paramount to be satisfied in its sole discretion that all material approvals, consents and franchise transfers relating to Time's programming and cable television business had been obtained on terms satisfactory to Paramount; (iv) removal of a number of Time-created or Time-controlled impediments to closing of the offer (e.g., redemption of a "poison pill” preferred rights purchase plan) or effectuation of a second-stage merger (e.g., supermajority voting requirements of 8 Del. C. Sec. 205 and supermajority voting provisions of Time's certificate of incorporation); and (v) financing and majority acceptance of the offer (Ibid , p. 969). 
Alguns acionistas da Time buscaram impedir que a administração realizasse a oferta pelas ações da Warner, a fim de disporem da oportunidade de escolher entre as operações pretendidas.

A controvérsia foi submetida aos tribunais norte-americanos de Delaware ${ }^{434}$, que reconheceram que embora os acionistas da Time aparentemente tenham preferido o valor mais alto proposto pela Paramount, em sua oferta pública de aquisição de ações da Time, o Conselho de Administração da Time não estava em situação semelhante àquela do caso Revlon v. MacAndrews and Forbes (i.e., tomada de controle inevitável e buscando uma operação com terceiro mais alinhado à administração); entendendo que a estratégia dos administradores da Time revelava-se coerente com a perspectiva de sua valorização de longo prazo e de seus negócios em geral.

Os tribunais de Delaware entenderam que os administradores não estavam dirigindo sua atuação para a satisfação de interesses pessoais, mas sim para a preservação da estratégia de longo prazo da Time. Como consequência final, os membros do Conselho de Administração da Time não foram responsabilizados nas acusações que lhes foram feitas.

\subsubsection{PARAmount COMmunications, INC. V. QVC NETWORK, INC}

Outro importante caso de destaque submetido à Suprema Corte de Delaware foi o Paramount Communications, Inc. v. QVC Network, Inc ${ }^{435}$. Este precedente é famoso pela irônica semelhança com o caso Paramount v. Time, embora a Paramount, aqui, tenha-

\footnotetext{
434 “[T] he court is required to express an opinion on the question of whether the directors of Time, who plainly have been granted the legal power to complete a public tender offer transaction that would be the first stage in accomplishing a thoughtfully planned consolidation of the business of Time with that of Warner Communications, have a supervening fiduciary obligation to desist from doing so in order that it be made more likely that the shareholders of Time will be afforded an opportunity to accept the public tender offer for all shares extended by Paramount's KDS subsidiary" (CHOPER, Jesse H.; COFFEE Jr., John C.; e GILSON, Ronald J. Cases and materials on corporations. 7. ed. Nova York: Aspen Publishers, 2008, p. 964).

${ }^{435}$ Paramount Communications, Inc. v. QVC Network, Inc. (637 A.2d 34, Delaware, 1994, Rel. E. Normal Veasey).
} 
se colocado na posição anteriormente ocupada pela Time, contra a qual a própria Paramount se opunha no caso Paramount v. Time.

Em resumo dos fatos, desde o início da década de 1980, a Paramount estava analisando a possibilidade de adquirir ou incorporar outras sociedades com empreendimentos ligados à indústria do entretenimento, tendo inclusive tentado adquirir o controle da Time, sem, no entanto, obter êxito em tal empreitada, como vimos na batalha travada no caso Paramount v. Time.

A partir do início da década de 1990, a Paramount e a Viacom começaram a analisar operações que potencialmente poderiam ser realizadas para combinar as atividades destas duas companhias. As negociações evoluíram e, em setembro de 1993, o Conselho de Administração da Paramount aprovou a celebração de contrato que continha disposições destinadas a cessar propostas competitivas pelo controle da Paramount, dentre as quais: (i) uma cláusula de exclusividade, que impedia a Paramount de negociar qualquer operação de reorganização societária e/ou concentração de sociedades com terceiros, a menos que o terceiro pudesse demonstrar que a sua proposta não estaria associada à criação de contingências financeiras; (ii) uma opção de compra de ações concedida à Viacom, facultando-a comprar ações correspondentes a 20\% do capital social da Paramount, por valor inferior ao preço de mercado, caso a operação entre Paramount e Viacom não fosse concluída ${ }^{436}$; e (iii) uma multa rescisória de US\$ 100 milhões, caso o negócio Paramount e Viacom não fosse concluído (break-up fee).

A despeito da existência de todas estas disposições contratuais, a QVC decidiu realizar uma oferta concorrente com a Viacom, demonstrando inicialmente que sua proposta não estaria associada à criação de contingências financeiras. Após várias rodadas de propostas entre, de um lado, a QVC e, de outro, a Viacom, o Conselho de Administração da Paramount anunciou que recomendaria aos acionistas a aceitação da proposta da Viacom e continuaria a resistir à oferta da QVC.

Paramount respaldou-se em argumentos utilizados por Time, no caso Paramount v. Time, sustentando a não aplicação dos “Deveres Revlon”.

\footnotetext{
${ }^{436}$ A Viacom poderia optar entre comprar as ações da Paramount ou demandar que a Paramount lhe pagasse a diferença entre este preço de compra e o valor de cotação em bolsa.
} 
Em meio à discussão judicial, $Q V C$ demonstrou que a interpretação da Paramount estava equivocada, uma vez que as circunstâncias fáticas em Paramount v. Time eram distintas daquelas existentes em Paramount v. QVC.

A $Q V C$, em tal discussão judicial, demonstrou, ainda, que se os "Deveres Revlon” não eram aplicáveis, então a defesa da Paramount deveria ser orientada pelos “Deveres Unocal”, de modo que os administradores deveriam analisar se a tomada de controle seria uma ameaça aos negócios da companhia e, se assim fosse, deveriam adotar medidas defensivas proporcionais à ameaça representada pela tentativa de tomada de controle.

Entretanto, ao final, os tribunais de Delaware validaram a recusa à proposta de aquisição hostil sob o argumento de que a decisão do Conselho de Administração de implementar a estratégia de negócios de longo prazo seria razoável e atenderia melhor ao interesse dos acionistas.

\subsubsection{PRECEDENTES AOS CASOS PARAdigMÁticos}

Embora os casos paradigmáticos acima examinados sejam academicamente reconhecidos como os mais importantes no estudo dos poderes e deveres da administração diante de tentativas de tomada de controle, há dois casos anteriores a estes, nos quais as discussões sobre o modelo de conduta (model of conduct) dos administradores já havia começado a se delinear nas interpretações jurisprudenciais, da mesma forma como se iniciavam a formação dos padrões de revisão (standards of review) dos tribunais em relação à atuação de administradores em tomadas de controle.

Aos poucos, abandonava-se a forma ultrapassada de analisar tais casos com o amparo na simples violação do dever fiduciário dos administradores, reconhecendo paulatinamente a complexidade envolvida em tomadas de controle. 
O primeiro de tais casos foi o Cheff $v$. Mathes ${ }^{437}$, em que a Suprema Corte de Delaware apreciou uma recompra de ações com ágio, em que todas as ações pertencentes a um acionista dissidente foram adquiridas pela companhia, em operação clássica de greenmail. De um lado, a Suprema Corte de Delaware expôs que a recompra teria o efeito de manter os atuais administradores da companhia em seus cargos, em discussão sobre “entrincheiramento” da administração. De outro lado, porém, entendeu que sendo o objetivo primeiro do Conselho de Administração promover a continuidade, evolução e avanço da atividade social, a operação de recompra não violava os deveres fiduciários dos administradores $^{438}$.

O segundo caso apontado como precursor foi o Schnell v. Chris-Craft Industries $^{439}$, em discussão sobre violação de dever fiduciário por administradores da companhia que anteciparam a assembleia anual, a fim de tornar impossível o procedimento de solicitação de procurações para eventual organização de exercício coletivo de votos destinada à substituição de tais administradores.

A doutrina norte-americana, nas palavras de William Allen e Reinier Kraakman, prevê que:

[a]lthough Cheff and Schnell dealt intelligently with a board's use of corporate power to maintain control, neither case afforded useful doctrinal tools for examining entrenchment measures more generally. However, the extraordinary growth in number of M\&A transactions - and especially hostile tender offers - in the late 1970s and early 1980s made the question of a director's fiduciary duty in the face of a takeover bid inescapable ${ }^{440}$.

\section{3 \\ LIMITES À ATUAÇÃO DA ADMINISTRAÇÃO}

\footnotetext{
${ }^{437}$ Cheff v. Mathes (199 A.2d 548, Delaware, 1964, Rel. James B. Carey).

${ }^{438}$ Cf. nota de rodapé 401, à época os tribunais norte-americanos analisavam os preceitos de dever fiduciário na atuação da administração em operações de tomada de controle com base nos mesmos critérios adotados em qualquer outra questão societária. Esta abordagem seria revolucionada a partir da década de 1980. ${ }^{439}$ Schnell v. Chris-Craft Industries, Inc. (285 A.2d 437, Delaware, 1971, Rel. Daniel L. Herrmann).

${ }^{440}$ ALLEN, William T.; KRAAKMAN, Reinier. Commentaries and Cases on the Law of Business Organization. Nova York: Aspen Publishers, 2003, pp. 498-500.
} 
Analisando os poderes e deveres da administração, discute-se qual a postura que se espera dos administradores diante de tentativas de tomada de controle.

Em diversos sistemas jurídicos há restrições à adoção de medidas defensivas, a partir do momento em que as ofertas públicas de aquisição de ações se tornem conhecidas, seja: (i) limitando a possibilidade de utilizá-las sem o consentimento dos acionistas enquanto vigorar a oferta (board neutrality); ou (ii) tornando excepcionalmente ineficazes, em relação ao ofertante, alguns efeitos decorrentes de medidas defensivas (break-trough rule).

Esta é a postura genérica estabelecida, por exemplo, nos países-membros da UE, em decorrência da Diretiva nº 2004/25/CE, que será examinada no item 9.1.

\subsubsection{NEUTRALIDAdE Do CONSELHO DE AdMINISTRAÇÃo (BoARD NEUTRALITY)}

A neutralidade do Conselho de Administração (board neutrality) é a recomendação de que a administração deve ser imparcial em ofertas públicas tendentes a promover a tomada do controle da companhia pelo ofertante ${ }^{441}$. Neste passo, a administração não pode adotar nenhuma medida que possa frustrar a oferta pública realizada, sem a prévia autorização dos acionistas da companhia-alvo ${ }^{442}$.

A imposição de regras de neutralidade visa a disponibilizar os meios para que os próprios acionistas possam escolher quanto à aceitação ou rejeição da oferta pública, amigável ou hostil, sem a intervenção da administração.

Certamente, a postura de evitar a intervenção da administração diante de ofertas públicas de tomada de controle revela elementos positivos e negativos.

\footnotetext{
${ }^{441}$ LEITÃO, Luís Manuel Teles de Menezes. As medidas defensivas contra uma oferta pública de aquisição hostil. O Direito. Ano 138, t. III, Coimbra: Almedina, 2006, pp. 466-467.

${ }^{442}$ De acordo com o item (2) do artigo $9^{\circ}$ da Diretiva $n^{\circ}$ 2004/25/CE, “[...] o órgão de administração da sociedade visada é obrigado a obter a autorização prévia da assembleia geral de acionistas para o efeito antes de empreender qualquer ação suscetível de conduzir à frustração da oferta, excetuando a procura de outras ofertas e, nomeadamente, antes de proceder a qualquer emissão de valores mobiliários susceptível de impedir de forma duradoura que o oferente assuma o controlo da sociedade visada”.
} 
De um lado, regras de neutralidade evitam casos em que a administração, imbuída de interesse próprio, opõe-se à oferta pública e/ou cria óbices intransponíveis para sua conclusão bem-sucedida. Reconhece-se, também, que a adoção de medidas defensivas pode limitar a criação de riquezas em eventuais disputas pelo controle societário, uma vez que, na existência de proteções, a tendência é que apenas as ofertas públicas amigáveis sejam levadas adiante. Vale lembrar que estas usualmente proporcionam benefícios consideráveis à administração e, em alguns casos, não aos acionistas.

Por outro lado, as recomendações de não intervenção da administração em ofertas públicas de tomada de controle revelam elementos negativos. Em companhias abertas dotadas de dispersão acionária, que são o alvo essencial das tentativas de tomada de controle, os acionistas em regra não dispõem de ampla e fundamentada informação sobre a companhia e seus negócios. Em tais casos, a administração está em melhores condições de julgar se o preço proposto na oferta está adequado, elevado ou inferior ao que poderia ser obtido. Além disso, há dificuldades de coordenar uma ação coletiva dos acionistas para, em conjunto, negociar melhores condições para a tomada hostil. Sob estes pontos de vista, o envolvimento da administração pode ser extremamente benéfico aos acionistas da companhia-alvo.

Com esta permissão, a administração poderia aliviar a pressão sobre os acionistas em reagir à oferta, e negociar as melhores condições de venda, com informação sobre os projetos futuros da companhia que os acionistas não dispõem.

Somos de opinião que as regras de neutralidade da administração ${ }^{443}$, que surgem a fim de reduzir os problemas de agência entre acionistas e administradores, não devem ser entendidas como solução dos problemas no exercício da função dos administradores em operações de tomadas de controle. Conforme exposto, há importantes elementos positivos em tal envolvimento, que não podem ser descartados ${ }^{444}$.

Além disso, a regra da neutralidade da administração assume a premissa de que a atuação dos administradores de companhias em tentativas de tomada de controle será

\footnotetext{
${ }^{443}$ Tal como a vigente na CE, em decorrência da Diretiva n ${ }^{\circ}$ 2004/25/CE.

${ }^{444}$ As próprias exceções estabelecidas no item (2) do artigo $9^{\circ}$ da Diretiva $n^{\circ}$ 2004/25/CE, em especial a procura de ofertas concorrentes, que consiste na medida defensiva do cavaleiro branco (white knight), é uma forma de reconhecimento destes elementos positivos.
} 
tendente a auferir benefícios próprios. Há, aqui, nítida presunção de má-fé na atuação dos administradores, quando na verdade deveria haver presunção de boa-fé, na certeza de que as disfunções no exercício de cargos na administração deverm ser tratadas com o rigor da lei, aplicando-se-lhe todas as sanções possíveis.

Se, por um lado, há orientação de neutralidade da administração nos paísesmembros da UE, por outro lado, nos EUA, há recomendação de que a administração não pode se manter passiva diante de uma tentativa de tomada de controle ${ }^{445}$.

O posicionamento passivo da administração é veementemente rejeitado nos EUA, sob o reconhecimento de que o Conselho de Administração está investido de uma função de proteção à companhia (gatekeeping function) ${ }^{446}$ em operações de tomada de controle desta.

A aplicação de regras de neutralidade à administração (board neutrality) restringe a utilização das medidas defensivas posteriores, analisadas no item 5.1.1.

\subsubsection{RESTRIÇõEs Às MEDIDAS DEFENSIVAS (BREAK-THROUGH RULES)}

As restrições às medidas defensivas denominadas break-through rules consistem em regras destinadas a excepcionar os efeitos de determinadas medidas defensivas durante o período compreendido entre o anúncio público e o prazo limite para

\footnotetext{
${ }^{445}$ Conforme Unocal v. Mesa Petroleum Co. (493 A.2d 946, Delaware, 1985, Rel. Andrew G. T. Moore), examinado no item 8.2.2. A este respeito, Stephen M. Bainbridge ensina que: "Unocal established the legal ability of a target's board of directors to reinsert itself into the tender offer process as a gatekeeer, even though the tender offer seemingly has been designed to bypass the need for target board approval”. E prossegue, em oposição à orientação da doutrina inglesa sobre a matéria, rejeitando a passividade da administração proposta pelos ingleses: "even cases giving Revlon an expansive reading continued to reject Easterbrook and Fischel's notion that the target board of directors should be mere passive observers of market competition” (BAINBRIDGE, Stephen M. Unocal at 20: Director Primacy in Corporate Takeovers. Law \& Economics Research Papers Series. UCLA School of Law, Research Paper n. 05-19, p. 11).

${ }^{446}$ Sobre o tema, refira-se a BAINBRIDGE, Stephen M. Op. cit., pp. 1-66; e a ALLEN, William T.; JACOBS, Jack B.; STRINE JR., Leo E. Function over Form: A Reassessment of Standards of Review in Delaware Corporation Law. The Business Lawyer, n. 56, 2001, pp. 1-20.
} 
aceitação de uma oferta pública de aquisição de ações, tendente a promover tomada de controle $^{447}$.

A ideia é assegurar que ofertas públicas poderão ser realizadas sem que medidas defensivas existentes prejudiquem-nas. Caso a companhia tenha adotado medida defensiva, cujos efeitos tenham sido compreendidos na suspensão temporária estabelecida pela break-through rule, tal defesa não estará eficaz em relação ao ofertante e não impedirá a fluência dos procedimentos da oferta pública de aquisição.

O direito comparado revela que as break-through rules têm sido adotadas por parte dos países-membros da UE, em decorrência das recomendações contidas na Diretiva $n^{0}$ 2004/25/CE, cujo artigo 11 contempla norma facultativa aos países-membros da UE ao prever que, entre o anúncio da oferta pública e o termo final para aceitação da oferta pública, não serão oponíveis as restrições à transmissão de valores mobiliários e ao exercício do direito de voto ${ }^{448}$.

As break-through rules alcançam não apenas medidas defensivas adotadas após a oferta pública de ações, como também as medidas defensivas preventivas, inclusive, em determinados casos, aquelas que constavam do estatuto social da companhia-alvo previamente ao anúncio da oferta pública.

\subsection{DEVERES FIDUCIÁRIOS (FIDUCIARY DUTIES)}

Os deveres fiduciários, assim chamados em tradução à expressão fiduciary duties, são considerados um dos conceitos de maior relevância no sistema jurídico da common law ${ }^{449}$.

\footnotetext{
${ }^{447}$ LEITÃO, Luís Manuel Teles de Menezes. As medidas defensivas contra uma oferta pública de aquisição hostil. O Direito. Ano 138, t. III, Coimbra: Almedina, 2006, pp. 466-467.

${ }^{448}$ Conforme artigo 11 da Diretiva no 2004/25/CE, examinado em maiores detalhes no item 9.1.

${ }^{449}$ BAUMAN, Jeffrey D.; WEISS, Elliot J.; PALMITER, Alan R. Corporations - Law and Policy Materials and Problems. 5. ed. Saint Paul: Thomson - West Group, 2003, p. 607.
} 
A ideia de que os membros dos órgãos de administração, especialmente os conselheiros de administração, possuem deveres fiduciários perante a companhia, tal como se fossem seus trustees, foi desenvolvida nos EUA e na Inglaterra.

A analogia à figura do trust deve-se historicamente ao fato de que, antes de 1844, a maioria das companhias na Inglaterra e nos EUA (à época referidas como joint stock companies) não eram formalmente constituídas e, portanto, não eram dotadas de personalidade jurídica. Desta maneira, aplicavam-se às companhias relações jurídicas próprias dos trusts ${ }^{450}$. Por estas razões, os administradores de tais sociedades atuavam como trustees, sendo responsáveis pelos bens, direitos e obrigações de tais sociedades ${ }^{451}$.

Em consequência, os deveres atribuídos aos administradores de companhias tornaram-se semelhantes aos deveres aplicáveis aos trustees, que sempre foram amplos e abrangentes.

Os deveres fiduciários traduzem a obrigação de que os administradores atuem de acordo com a confiança que lhes foi depositada pelos acionistas, e a atribuição de tais deveres lastreia-se no direito das relações de representação ${ }^{452}$.

O desenvolvimento dos deveres fiduciários foi fomentado pela teoria dos conflitos de representação entre representado e representante (principal v. agent), da qual decorrem os problemas de agência (agency problems), também referidos como problemas de representação ${ }^{453}$.

\footnotetext{
${ }^{450}$ HOPT, Klaus J. Deveres legais e conduta ética de membros do conselho de administração e de profissionais. Tradução de Erasmo Valladão A. e N. França e Mauro Moisés Kertzer. RDM. São Paulo: Malheiros, n. 144, pp. 107-119, out./dez. 2006.

${ }^{451}$ Para explanação cuidadosa sobre a diferença dos deveres fiduciários aplicáveis aos administradores de companhias e aos trustees, referir-se a SILVA, Alexandre Couto. Responsabilidade dos Administradores de S/A: Business Judgment Rule. Rio de Janeiro: Elsevier, 2007, especialmente nas pp. 10-13.

${ }^{452}$ Noticia-se que a utilização dos deveres fiduciários para os administradores de companhias origina-se do Law of Agents, direito referente às relações de representação em sentido amplo (ALLEN, William T.; KRAAKMAN, Reinier. Commentaries and Cases on the Law of Business Organization. Nova York: Aspen Publishers, 2003, pp. 30-31).

${ }^{453}$ Os conflitos entre principal e agent surgem sempre que há divergências entre os interesses dos representantes e dos seus representados. No âmbito das companhias são comuns as referências aos agency problems (i) entre acionistas e administradores; (ii) entre acionistas controladores e minoritários; e (iii) entre a companhia e terceiros com quem ela contrata (credores, trabalhadores e consumidores). (HANSMANN, Henry e KRAAKMAN, Reinier R. Agency Problems and legal Strategies. In: KRAAKMAN, Reinier et al. The Anatomy of Corporate Law: A Comparative and Functional Approach. Oxford: Oxford University Press, 2004, pp. 21-31).
} 
$\mathrm{Na}$ relação entre Conselho de Administração e acionistas de grandes companhias, atribui-se ao conselheiro de administração a função de agent e aos acionistas o papel de principal.

Atualmente, a extensão dos deveres fiduciários e as responsabilidades que dele decorrem são altamente questionáveis. É importante observar que, em muitos casos, os deveres fiduciários em sua concepção ampla, tal como vigente nos países de common law, se revela inaplicável ao Brasil, que, seguindo a tradição romano-germânica, capitula os deveres legais dos administradores ${ }^{454}$.

É interessante a ponderação de Luiz Antônio Sampaio Campos sobre o assunto:

\begin{abstract}
A referência vaga aos chamados deveres fiduciários, os fiduciary duties, conceitos aprofundados e desenvolvidos nos direitos norte-americano e inglês, e toda a construção jurisprudencial dos tribunais daqueles países não têm aplicação direta no Brasil. Daí a necessidade de se criarem normas que trouxessem para o direito positivo, com as devidas adaptações, os conceitos pertinentes, e autorizassem sua aplicação no Brasil - o que também explica o tratamento detalhado dado à matéria pelo legislador brasileiro. ${ }^{455}$
\end{abstract}

Em linha com o que será exposto adiante, deve-se lembrar que a legislação acionária brasileira relaciona, cuidadosamente, os deveres dos administradores, enquanto no regime de common law estes deveres decorrem de precedentes submetidos à apreciação da jurisprudência.

\footnotetext{
${ }^{454}$ Já assentamos entendimento anterior neste sentido (cf. NASCIMENTO, João Pedro Barroso do; VAZ, Ernesto Luís Silva. Poderes da Administração na oferta hostil de aquisição de controle no direito comparado (medidas defensivas e poison pills). In: FRANÇA, Erasmo Valladão Azevedo e Novaes [coord.]. Direito Societário Contemporâneo I. São Paulo: Quartier Latin, 2009, pp. 387-422.

${ }^{455}$ CAMPOS, Luiz Antonio de Sampaio. Conselho de Administração e Diretoria. In: LAMY FILHO, Alfredo; BULHÕES PEDREIRA, José Luiz. Direito das Companhias. v. 1, Rio de Janeiro: Forense, 2009, p. 1088.
} 
Na doutrina norte-americana ${ }^{456}{ }_{-}^{457}$ verifica-se que os fiduciary duties podem ser classificados em três categorias.

A primeira categoria seria a do dever de obediência aos documentos que deram origem à relação jurídica ${ }^{458}{ }^{459}$.

A segunda categoria abrange o dever de lealdade ${ }^{460}$, definido como "pervasive obligation always to exercise fiduciary power in a manner that the holder of the power believes in good faith is the best to advance the interests or purposes of the beneficiary and not to exercise for a personal benefit” ${ }^{461}$. Trata-se da classificação de maior importância ${ }^{462}$.

Por fim, há a categoria do dever de diligência ${ }^{463}{ }^{464}$. Robert Clark ressalta que a definição do dever de diligência pode ser encontrada tanto em leis quanto em decisões judiciais e que consistiria na atuação com habilidade, diligência e cuidado, tal como agiria uma pessoa razoável em circunstâncias semelhantes, ou, em abordagem mais restrita, na

456 ALLEN, William T.; KRAAKMAN, Reinier. Commentaries and Cases on the Law of Business Organization. Nova York: Aspen Publishers, 2003, p. 31.

${ }^{457}$ Ibid., p. 2. A classificação proposta para os casos em que é utilizado o conceito dos deveres fiduciários guarda estreita relação com a categorização proposta por um dos co-autores, William T. Allen, em outra obra, conforme indicado na nota 404 (ALLEN, William T.; JACOBS, Jack B.; STRINE JR., Leo E. Function over Form: A Reassessment of Standards of Review in Delaware Corporation Law. The Business Lawyer, n. 56, 2001).

${ }^{458}$ ALLEN, William T.; KRAAKMAN, Reinier, Op. cit., pp. 31; 239.

${ }^{459}$ William Allen, Jack Jacobs e Leo Strine Jr. enquadram nesta categoria os casos em que os administradores têm “interesse de entrincheiramento" (entrenchment interest), isto é, proteção de sua posição na administração da companhia (ALLEN, William T.; JACOBS, Jack B.; STRINE JR., Leo E. Op. cit.).

${ }^{460}$ William Allen, Jack Jacobs e Leo Strine Jr. enquadram nesta categoria os casos em que há discussão a respeito do dever de lealdade, tratando-se primordialmente de negócios consigo mesmo, notadamente quando a companhia faz negócios em que os administradores tenham interesses e têm o dever de apresentar as justificativas do negócio, indicando suas principais características, termos e condições (Ibid., p. 2). Também neste caso há tratamento específico e amplo na legislação societária nacional, conforme artigo 155 da Lei $\mathrm{n}^{\circ}$ $6.404 / 76$.

461 Ibid., p. 31; 285 e ss.

462 Ou, nas palavras de ALLEN, William T.; JACOBS, Jack B.; STRINE JR., Leo E., é o dever fiducinário que "has the longest pedigree" (Ibid., p. 2).

${ }^{463}$ ALLEN, William T.; KRAAKMAN, Reinier. Op. cit., pp. 31; 239 e ss. Ainda, segundo ALLEN, William T.; JACOBS, Jack B.; STRINE JR., Leo E., o dever de diligência teria passado a ser considerado conceito jurídico autônomo do dever de lealdade em Delaware depois de 1985 (Op. cit., p. 2). Em sentido diferente, BAUMAN, Jeffrey D.; WEISS, Elliot J.; PALMITER, Alan R. Corporations - Law and Policy - Materials and Problems. 5. ed. Saint Paul: Thomson - West Group, 2003, p. 607; 608.

${ }^{464}$ William Allen, Jack Jacobs e Leo Strine Jr. enquadram nesta categoria os casos em que os administradores não tenham agido com o cuidado necessário (ALLEN, William T.; JACOBS, Jack B.; STRINE JR., Leo E. Op. cit. p.2). Na lei societária brasileira há capitulação específica para o dever de diligência, nos termos do artigo 153 da Lei $n^{\circ}$ 6.404/76, onde se vê grande semelhança com o conceito do standard of care encontrado no direito norte-americano. 
atuação igual a de uma pessoa razoavelmente prudente na condução de seus próprios negócios ${ }^{465}$.

Os deveres fiduciários de administradores e acionistas controladores são conceitos versáteis, que têm gerado não apenas o que há de novo e interessante no moderno direito societário, mas também o que é frustrante na jurisprudência norteamericana, notadamente no que se refere à aplicação dos deveres da administração em takeovers hostis $^{466}$.

A notória qualidade da legislação acionária brasileira restringe o espaço para o mau uso dos deveres fiduciários. Nestes termos, recorra-se uma vez mais a opinião de Luiz Antônio Sampaio Campos:

Aqui cabe, porém, uma advertência preliminar, no sentido de que o intérprete e o aplicador da LSA não se devem impressionar com as referências vagas - e, muitas vezes, inapropriadamente utilizadas - aos chamados "deveres fiduciários”, devendo se restringir às interpretações que a lei e o direito vigentes no Brasil lhe autorizam ${ }^{467}$.

Os deveres fiduciários são inerentes às relações em trusts, instituto típico do direito da common law, e não devem ser aplicados da mesma forma às companhias, especialmente no Brasil.

Sendo assim, na hipótese de utilização no Brasil de casos precedentes oriundos do exterior, como fonte de inspiração sobre aplicação de regras atinentes à atuação de administradores em tomadas de controle, os deveres fiduciários devem ser desdobrados em feixes de deveres aplicáveis aos administradores de companhias brasileiras, conforme

\footnotetext{
${ }^{465}$ Referindo-se a leis societárias de diversos estados norte-americanos: CLARK, Robert Charles. Corporate Law. Boston / Toronto: Little, Brown and Company, 1986, p. 123.

${ }^{466}$ Um instituto jurídico tão amplo suscita questionamentos sobre imprecisão conceitual em sua aplicação. Contudo, tratando-se de conceito jurídico indeterminado, este permite a evolução das interpretações no tempo, constante evolução do direito (ALLEN, William T.; JACOBS, Jack B.; STRINE JR., Leo E. ALLEN, William T.; JACOBS, Jack B.; STRINE JR., Leo E. Function over Form: A Reassessment of Standards of Review in Delaware Corporation Law. The Business Lawyer, n. 56, 2001, p. 2).

${ }^{467}$ CAMPOS, Luiz Antonio de Sampaio. Conselho de Administração e Diretoria. In: LAMY FILHO, Alfredo; BULHÕES PEDREIRA, José Luiz. Direito das Companhias. v. 1, Rio de Janeiro: Forense, 2009, p. 1088.
} 
previstos nos artigos 153 a 158 da Lei $n^{0}$ 6.404/76. Só assim a experiência estrangeira fornecerá subsídios adequados entre nós.

8.5 REgRa do Julgamento do NEgócio (BUSINESS JUdGMENT RULE)

A regra de julgamento do negócio (business judgement rule) surgiu no direito norte-americano como um padrão de revisão (standards of review) utilizado pelos tribunais na interpretação de casos envolvendo decisões de administradores de companhias ${ }^{468}$, inclusive em operações de tomada de controle ${ }^{469}$.

Segundo a regra de julgamento do negócio (business judgement rule) ${ }^{470}$, os atos de gestão dos administradores não podem se sujeitar ao controle jurisdicional senão em sua legalidade, isto é, em sua consonância com as normas de direito, excluindo-se do controle jurisdicional o exame de seu conteúdo. António Menezes Cordeiro resume que "a sindicância jurisdicional tem a ver com a licitude da atuação, não com o seu mérito”471.

Segundo Robert Clark $^{472}$, respeitadas certas exceções, as decisões negociais não podem ser contestadas ou revertidas pelos acionistas ou pelos tribunais e os

\footnotetext{
${ }^{468}$ Conforme exposto no item 8.1 deste trabalho.
}

${ }^{469}$ Alexandre Couto Silva, citando casos de diferentes estados norte-americanos, ensina que, nos EUA, há tempos recusa-se a atuação do Poder Judiciário como uma segunda instância de análise das decisões negociais tomadas por administradores (SILVA, Alexandre Couto. Responsabilidade dos Administradores de S/A: Business Judgment Rule. Rio de Janeiro: Elsevier, 2007, p. 141).

${ }^{470}$ William T. Allen e Reinier Kraakman ressaltam que não há apenas uma única definição da regra do julgamento do negócio e que o mais próximo de uma definição que se pode ter é a contida no American Bar Association's Corporate Director's Guidebook, que contém elementos referentes ao desinteresse financeiro, à obtenção das informações devidas e à atuação em boa-fé (ALLEN, William T.; KRAAKMAN, Reinier. Commentaries and Cases on the Law of Business Organization. Nova York: Aspen Publishers, 2003, pp. 251-252). A abrangência na aplicação da regra do julgamento do negócio não é pacífica na jurisprudência norte-americana. A este respeito, cf. EISENBERG, Melvin Aron; CARY, William L. Corporations: Cases and Materials. 7. ed. Nova York: Foundation Press, 1995, p. 410.

${ }^{471}$ CORDEIRO, António Manuel da Rocha e Menezes. Da Responsabilidade Civil dos Administradores das Sociedades Comerciais. Lisboa: Lex, 1977, p. 523.

${ }^{472}$ CLARK, Robert Charles. Corporate Law. Boston / Toronto: Little, Brown and Company, 1986, p. 123. Para o autor, "[...] the business judgment rule is just a corollary of the usual statutory provision that it is the directors who shall manage the corporation. The rule is simply that the business judgement rule of the directors will not be challenged or overturned by courts or shareholders, and the directors will not be held liable for the consequences of their exercise of business judgment - even for the judgments that appear to have been clear mistakes - unless certain exceptions apply”. 
administradores não podem ser considerados responsáveis pelas consequências do exercício de suas decisões negociais.

A regra do julgamento do negócio (business judgement rule), encontra guarida no artigo 159 , $\S 6^{\circ}$, da Lei $n^{\circ} 6.404 / 76^{473}$, e consiste em reconhecer que o Poder Judiciário não deve rever o mérito de decisão negocial tomada pela administração, encorajando os administradores a servir à companhia, de forma equilibrada, porém, assumindo riscos inerentes ao empreendedorismo.

A possibilidade de revisão de atos de gestão pelo Poder Judiciário aumenta significativamente a exposição dos administradores, podendo fazer com que estes deixem de tomar decisões mais arriscadas, inovadoras e criativas, apenas para evitar eventual responsabilidade aplicada na revisão judicial posterior.

Segundo Alexandre Couto Silva: ${ }^{474}$

[a] business judgment rule é um conceito jurídico amplo de que os administradores têm a presunção de boa decisão ou julgamento do negócio, e essas decisões não estão afetadas se tomadas por uma proposta administrativa racional.

Presume-se que, em uma tomada de decisão, os administradores atuarão de boa-fé, devidamente informados e no interesse da companhia, Para rebater a presunção, o autor (acionista) assume a responsabilidade de provar que o Conselho de Administração quebrou qualquer uma das tríades dos deveres fiduciários: boa-fé, lealdade e diligência. Contrariamente, a business judgment rule protegerá os administradores e a decisão tomada.

A nascente da regra de julgamento do negócio (business judgement rule) está em preocupar-se com o processo decisório ${ }^{475}$ e não com o mérito da decisão, devendo o

473 Artigo 159, §6 $6^{\circ}$, da Lei $n^{\circ}$ 6.404/76: O juiz poderá reconhecer a exclusão da responsabilidade do administrador, se convencido de que este agiu de boa-fé e visando ao interesse da companhia.

${ }^{474}$ SILVA, Alexandre Couto. Responsabilidade dos administradores de S/A: business judgment rule. Rio de Janeiro: Elsevier, 2007, p. 193.

475 “A consideração desta margem de discricionariedade e o reconhecimento do risco empresarial operam uma restrição das possíveis situações de ilicitude. Esta restrição da margem de ilicitude determina que, na prática, apenas sejam consideradas ilícitas as decisões irracionais ou absolutamente insustentáveis (e/ou com absoluta falta de obtenção de informação no iter decisional). Tendencialmente, as decisões dos administradores apenas serão ilícitas em situações de irracionalidade, absoluta irrazoabilidade ou absoluta falta de obtenção de informação no iter decisional. A ilicitude tende a restringir-se a situações de dolo ou de 
administrador seguir, resumidamente, os seguintes princípios: (i) princípio da decisão informada, que é aquela tomada com base em informações, documentos, análises e assessoria técnica especializada, as quais sejam necessárias ao exame do conteúdo da questão; (ii) princípio da decisão refletida, que é aquela adotada após exame das diferentes alternativas disponíveis, considerando as demais hipóteses e caminhos paralelos que poderiam ser seguidos em relação à decisão tomada; e (iii) princípio da decisão desinteressada, que é aquela que não resulta em benefício particular ao administrador.

É importante que se entenda que a regra de julgamento do negócio (business judgement rule) não protege toda e qualquer decisão de gestão tomada. O equilíbrio trazido por este conceito, para evitar o patente excesso do controle jurisdicional em relação a atos de gestão e decisões negociais, não pode ser entendido como uma excludente definitiva da apreciação do Poder Judiciário de decisões tomadas pela administração da companhia, inclusive no que se refere àquelas pertinentes às operações de tomada de controle.

A Lei $n^{0}$ 6.404/76 estabelece um louvável sistema descritivo dos deveres dos administradores, por meio dos artigos 153 a 157, para na sequência disciplinar a responsabilidade dos administradores no artigo 158. Luiz Antônio Sampaio Campos ${ }^{476}$, endossando lições de Luís Brito Correia ${ }^{477}$, precisamente aponta que “a divisão entre deveres e responsabilidades é pertinente, pois [...] indica que os deveres surgem antes da responsabilidade e independente desta”.

A preocupação do legislador pátrio foi estabelecer padrões de comportamento, a fim de guiar a atuação dos administradores da companhia, tendo este propósito sido

negligência grosseira” (NUNES, Pedro Caetano. Responsabilidade civil dos administradores perante os accionistas. Coimbra: Almedina, 2001, p. 93).

${ }^{476}$ CAMPOS, Luiz Antonio de Sampaio. Conselho de Administração e Diretoria. In: LAMY FILHO, Alfredo; BULHÕES PEDREIRA, José Luiz. Direito das Companhias. v. 1, Rio de Janeiro: Forense, 2009, p. 1085.

${ }^{477}$ CORREIA, Luís Brito. Os administradores de Sociedades Anônimas. Coimbra: Almedina, 1993, p. 597. Apud CAMPOS, Luiz Antonio de Sampaio. Op. cit., p. 1085. 
refletido na Exposição de Motivos da Lei $n^{0}$ 6.404/76 ao referir-se à "enumeração minuciosa, e até pedagógica, [d]os deveres e responsabilidades dos administradores” ${ }^{478}$.

Sendo assim, deve-se examinar de que maneira os padrões de comportamento estabelecidos pelo legislador brasileiro amoldam-se às reflexões sobre tomadas de controle e às defesas adotadas em oposição a estas últimas.

\subsubsection{DEVER DE DILIGÊNCIA}

O artigo 153 da Lei $\mathrm{n}^{\circ}$ 6.404/76 determina que o administrador da companhia deve empregar, no exercício de suas funções, o cuidado e diligência que todo homem ativo e probo costuma empregar na administração dos seus próprios negócios. Este é o dever de diligência aplicável aos administradores.

O dever de diligência é notoriamente o dever de maior amplitude na definição dos padrões de comportamento em nossa legislação acionária, conforme ensinam José Luiz Bulhões Pedreira e Alfredo Lamy Filho ${ }^{479}$, em lição que encontrou eco no direito societário nacional $^{480}$.

O dever de diligência é o mandamento básico e primordial do administrador, relativo à necessidade de empregar, no exercício de suas funções, os cuidados que todo homem ativo e probo deve ostentar, em alusão à figura jurídica consagrada do "bom pai de família”. A atuação da administração da companhia deve ser zelosa e cuidadosa em relação à companhia, tal como se esta fosse sua. Esta postura se revela tanto comissiva quanto

\footnotetext{
${ }^{478}$ A íntegra da Exposição de Motivos da Lei n ${ }^{\circ}$ 6.404/76 encontra-se publicada na conhecida obra de LAMY FILHO, Alfredo; BULHÕES PEDREIRA, José Luiz. A Lei das S.A. v. 1, Rio de Janeiro: Renovar, 1992, pp. 213-252.

479 Ibid., p. 235.

${ }^{480}$ ADAMEK, Marcelo Vieira von. Responsabilidade Civil dos Administradores de S/A (e as ações correlatas). São Paulo: Saraiva, 2009, p. 120. CAMPOS, Luiz Antonio de Sampaio. Conselho de Administração e Diretoria. In: LAMY FILHO, Alfredo; BULHÕES PEDREIRA, José Luiz. Direito das Companhias. v. 1, Rio de Janeiro: Forense, 2009, p. 1097. TEIXEIRA, Egberto Lacerda e GUERREIRO, José Alexandre Tavares, Das sociedades anônimas no direito brasileiro. vol. 2, São Paulo: José Bushatsky, 1979, p. 471; LIMA, Osmar Brina Correa. Responsabilidade civil dos administradores de sociedade anônima. Rio de Janeiro: Aide, 1989. p. 65; SILVA, Alexandre Couto. Responsabilidade dos administradores de S/A: business judgment rule. Rio de Janeiro: Elsevier, 2007. p. 15.
} 
omissivamente. O zelo e cuidado da administração deve se revelar em práticas que importem em ações e naquelas que importem em omissões.

O dever de diligência é um modelo de comportamento a ser empregado em casos concretos. Osmar Brina Correa Lima expõe que “[...] deve haver mais que honestidade nas transações de uma companhia. Deve haver diligência. E isso significa cuidado e prudência"481.

Entre nós, o dever de diligência seria o desdobramento do standard of care compreendido no abrangente dever fiduciário da common law, abordado no item 8.4. No Brasil, a legislação pormenoriza expressamente os deveres legais a que os administradores estão sujeitos, de modo que a utilização do dever fiduciário da common law deve respeitar esta premissa para ser aplicado entre nós. Reconhecendo este desdobramento do dever fiduciário, o standard of care, compreendido em tais deveres de inspiração norteamericana, pode fornecer interessantes bases para reflexão no Brasil sobre o amoldamento do dever de diligência em operações de tomada de controle.

Estudos pátrios específicos sobre a responsabilização de administradores de companhia ensinam que o dever de diligência é um conceito flexível ${ }^{482}$. Portanto, no desafio que ora se coloca de analisar o dever de diligência à luz das operações de tomada de controle, parece-nos adequada a reflexão realizada, em contexto distinto, por Pedro Oliva Marcilio de Sousa.

Apreciando, como relator, o Processo Administrativo Sancionador RJ-20051443, Pedro Oliva Marcilio de Sousa sugeriu a associação de conceitos da regra do julgamento do negócio (business judgement rule), com a aplicação do dever de diligência, podendo-se extrair o seguinte trecho de sua exposição:

\footnotetext{
${ }^{481}$ LIMA, Osmar Brina Correa. Responsabilidade civil dos administradores de sociedades anônimas. Rio de Janeiro: Aide, 1989, p. 67.

${ }^{482}$ ADAMEK, Marcelo Vieira von. Responsabilidade Civil dos Administradores de S/A (e as ações correlatas). São Paulo: Saraiva, 2009, p. 125-126; RIBEIRO, Renato Ventura. Dever de Diligência dos administradores de sociedades. São Paulo: Quartier Latin, 2006, p. 209; CASTELLO BRANCO, Adriano. $O$ Conselho de Administração nas sociedades anônimas. 2. ed. Rio de Janeiro: Forense Universitária, 2007, p. 124; BATALHA, Wilson de Souza Campos. Comentários à lei das Sociedades Anônimas. v. 2, Rio de Janeiro: Forense, 1977, p. 697; MAGALHÃES, Roberto Barcellos de. A Nova Lei das Sociedades por Ações Comentada. v. 2, São Paulo: Freitas Bastos, 1977, p. 706.
} 
A construção jurisprudencial norte-americana para o dever de diligência em nada discrepa do que dispõe o art. 153 da Lei 6.404/76, sendo possível utilizar-se, no Brasil, dos mesmos standards de conduta aplicados nos Estados Unidos. A utilização desses standards poderia fazer com que a aplicação do art. 153 fosse mais efetiva do que é hoje, pois poderíamos passar a observar o processo que levou à tomada da decisão para ver se os cuidados mínimos, que demonstram a diligência do administrador, foram seguidos, não nos limitando a simplesmente negar a possibilidade de re-análise do conteúdo da decisão tomada ${ }^{483}$.

A análise, em cada caso concreto, sobre o cumprimento do dever de diligência pelo administrador, deve compreender o processo decisório e o contexto em que os administradores tomaram a decisão negocial em relação à ameaça colocada pela tentativa de tomada de controle. Desta maneira, pode-se apurar os elementos que os orientaram a agir ou se omitir diante da tentativa de tomada de controle e, em cada uma destas opções, apurar elementos ocultos que possam ter orientado a decisão dos administradores.

O exame do cumprimento do dever de diligência será importante para também colocar à prova os demais deveres impostos à administração das companhias, que são consectários do dever de diligência.

\subsubsection{Finalidades das Atribuições e Desvio de Poder}

O caput do artigo 154 da Lei $\mathrm{n}^{\circ}$ 6.404/76 determina que o administrador deve exercer as suas atribuições para lograr os fins e o interesse da companhia, satisfeitas as exigências do bem público e da função social da empresa ${ }^{484}$.

O conteúdo deste dever é reconhecer que a atuação da administração é destinada à satisfação dos fins e interesses da companhia, decorrendo de tal conceito as

\footnotetext{
${ }^{483}$ CVM, Processo Administrativo Sancionador RJ-2005-1443, Rel. Dir. Pedro Oliva Marcilio de Sousa, j. 21.03.2006.

${ }^{484}$ Em interpretação histórica do dispositivo, nota-se que o trecho final do mesmo decorre do momento político vivido pelo Brasil durante a elaboração e discussões do Anteprojeto que resultou na Lei n ${ }^{\circ}$ 6.404/76.
} 
recomendações de que os administradores busquem sempre o fim social ${ }^{485}$ e o interesse da companhia.

Em sua atuação, os administradores não podem visar a benefícios próprios. Espera-se que, uma vez eleitos para ocupar cargo na administração da companhia, os administradores atuem em prol do interesse social, sendo vedado pelo artigo $154, \S 1^{\circ}$, da Lei $n^{\circ}$ 6.404/76 a existência de identificação de propósitos entre os administradores e os acionistas que os elegeram, proibindo-se que os administradores atuem em defesa de interesses próprios destes últimos.

Esta característica é importante diante de eventual atuação de administradores no sentido de defender, a todo custo, a tomada de controle da companhia em prol do atendimento do interesse de acionistas que os tenham escolhido para o cargo. O que se deve apurar é se a postura defensiva revela-se como o melhor método para atender o interesse social.

O administrador não pode usar indevidamente o poder que lhe é conferido, para atingir finalidade diversa daquela que a lei e o estatuto social determinam. O fim e o interesse social são vertentes fundamentais para auxiliar o administrador na escolha do caminho a ser seguido e da postura a ser adotada. A opção pela defesa ou pela ausência de defesa devem sempre orientar-se por estes parâmetros.

Neste compasso, o $\S 2^{\circ}$ do artigo 154 da Lei $n^{\circ}$ 6.404/76 enuncia que “é vedado ao administrador: (i) praticar ato de liberalidade à custa da companhia; (ii) sem prévia autorização da assembleia geral ou do Conselho de Administração, tomar por empréstimo recursos ou bens da companhia, ou usar, em proveito próprio, de sociedade em que tenha interesse, ou de terceiros, os seus bens, serviços ou crédito ${ }^{486}$; (iii) receber de terceiros,

\footnotetext{
${ }^{485}$ Sobre fim social, referir-se a FRANÇA, Erasmo Valladão Azevedo e Novaes; ADAMEK, Marcelo Vieira von. Affectio societatis: um conceito jurídico superado no moderno direito societário pelo conceito de fim social. In: FRANÇA, Erasmo Valladão Azevedo e Novaes (coord.). Direito Societário Contemporâneo I. São Paulo: Quartier Latin, 2009, pp. 131-162.

${ }^{486}$ A legislação penal também indica que o administrador não deve utilizar em proveito próprio os bens e ativos da companhia. Neste sentido, o artigo 177, $\S 1^{\circ}$, inciso III, do Código Penal prevê que incorre em pena de reclusão, de um a quatro anos, e multa, "[...] o diretor ou o gerente que toma empréstimo à sociedade ou usa, em proveito próprio ou de terceiro, dos bens ou haveres sociais, sem prévia autorização da assembléia geral”.
} 
sem autorização estatutária ou da assembléia geral, qualquer modalidade de vantagem pessoal, direta ou indireta, em razão do exercício de seu cargo”487.

As vedações estabelecidas nas alíneas “a”, “b” e “c” do §2º do artigo 154 da Lei $n^{0}$ 6.404/76 não somente revelam restrições aos administradores, como exteriorizam casos que podem eivar de vício a utilização de medidas defensivas por estes últimos, sobretudo em contexto em que os administradores estão interessados em proteger a companhia da tomada de controle a fim de manterem seus respectivos cargos.

Conforme exposto neste trabalho, em algumas das espécies de medidas defensivas examinadas no Capítulo VI há, usualmente, previsão de contrapartidas em favor de administradores para que estes resistam à tentativa de tomada de controle da companhia ou revelem-se mais favoráveis à conclusão de tal operação com terceiros que se revelem mais alinhados e, até mesmo, mais amistosos com estes últimos.

O $\S 4^{\circ}$ do artigo 154 da Lei $\mathrm{n}^{\circ}$ 6.404/76 enuncia que o Conselho de Administração ou a Diretoria podem autorizar a prática de atos gratuitos razoáveis em benefício dos empregados ou da comunidade de que participe, tendo em vista suas responsabilidades sociais. A autorização prevista neste dispositivo pode inserir-se no contexto de adoção da medida defensiva, mormente quando esta importe em redução da atratividade da companhia à tentativa de tomada de controle, sendo que tal perda de atratividade poderá ser justificada pelo cumprimento de responsabilidades sociais.

Enfim, de uma maneira geral, o desvio de poder caracteriza-se pelo desvirtuamento da finalidade da própria lei societária e do estatuto da companhia, embora preservados os elementos formais da respectiva regra.

O desvio de poder é uma fraude à lei e ao estatuto, mediante a manipulação e aplicação deformada de suas regras, visando a lograr fins outros que não os da companhia, deixando de observar as exigências do bem público e da função social da empresa.

A atuação dos administradores destinada a “entrincheirar-se” no cargo diante de uma tentativa de tomada de controle não sobreviveria ao exame pelas disposições do

${ }^{487} \mathrm{O} \S 3^{\circ}$ do artigo 154 da Lei ${ }^{\circ}$ 6.404/76 enuncia que as importâncias recebidas com infração ao disposto na alínea “c” do $\S 2^{\circ}$ do mesmo artigo pertencerão à companhia. 
artigo 154 da Lei $n^{0}$ 6.404/76. Da mesma forma, a atuação dos administradores como “mandatários” identificados com os interesses dos acionistas que os elegeram, tanto na adoção da defesa quanto na omissão diante do ataque, seria veementemente rejeitada com base neste dispositivo.

Por outro lado, o disposto no artigo 154 da Lei $n^{\circ}$ 6.404/76 poderia autorizar a adoção de medidas defensivas em determinados casos, quando estas se revelassem alinhadas com os fins e interesses da companhia, ainda que não priorizassem interesses individuais de determinados grupos de acionistas.

\subsubsection{DEVER DE LEALDADE}

O artigo 155 da Lei ${ }^{\circ}$ 6.404/76, que positiva o dever de lealdade na legislação societária, prescreve que o administrador deve servir com lealdade à companhia e manter reserva sobre os seus negócios, sendo-lhe vedado: (i) usar, em benefício próprio ou de outrem, com ou sem prejuízo para a companhia, as oportunidades comerciais de que tenha conhecimento em razão do exercício de seu cargo; (ii) omitir-se no exercício ou proteção de direitos da companhia ou, visando à obtenção de vantagens, para si ou para outrem, deixar de aproveitar oportunidades de negócio de interesse da companhia; e (iii) adquirir, para revender com lucro, bem ou direito que sabe ser necessário à companhia, ou que esta tencione adquirir.

O dever de lealdade é uma decorrência do comportamento ético que se espera dos administradores de companhias. Paulo Fernando Campos Salles de Toledo expõe que “[...] a lei [prevê] que o administrador deve servir com lealdade à companhia. Deve, portanto, ser fiel aos interesses e à finalidade da empresa, honrando os compromissos assumidos. Deve servir à companhia, e não servir-se dela”488.

\footnotetext{
${ }^{488}$ TOLEDO, Paulo Fernando Campos Salles de. O Conselho de Administração na Sociedade Anônima: estrutura, funções e poderes, responsabilidade dos administradores. 2. ed. São Paulo: Atlas, 1999, pp. 58-59.
} 
O dever de lealdade sugere condutas proibidas aos administradores das companhias, reputando em violação aquele administrador que praticar os atos contidos na relação enunciativa, porém, não exaustiva do caput do artigo 155 da Lei n 6.404/76.

O reconhecimento da existência de condutas proibidas é corolário da alta função exercida por administradores de companhias. Orientando e gerindo os negócios da companhia, os administradores tomam conhecimento de fatos que são ignorados por acionistas e por terceiros em geral, que podem repercutir decisivamente para a companhia ou para o mercado ${ }^{489}$.

O exercício do cargo na administração de companhias apresenta aos administradores oportunidades para a prática de atos de que podem resultar vultosas vantagens em seu próprio benefício, que, na maioria dos casos, não seriam de seu conhecimento se não ocupassem tais cargos. A ideia é de que tais oportunidades deverão favorecer a companhia e não os seus administradores, que devem estar orientados pelo dever de lealdade.

Conforme exposto no item 8.4, o dever fiduciário vigente nos EUA compreende uma amplitude de padrões de condutas, que entre nós pode ser desdobrada em alguns dos deveres aplicáveis aos administradores das companhias.

O dever de lealdade corresponderia, entre nós, ao standard of loyalty compreendido no amplo dever fiduciário norte-americano. Sendo assim, mesmo que a experiência nacional ainda seja acanhada em operações de tomada de controle e, consequentemente, na utilização concreta de defesas, as reflexões sobre a observância ao standard of loyalty em situações de tomada de controle nos países da common law pode auxiliar, na reflexão no Brasil, sobre o amoldamento do dever de lealdades às situações desta natureza que ocorrerem em nosso país.

\footnotetext{
${ }^{489}$ É nessa lógica que o $§ 1^{\circ}$ do artigo 155 da Lei no ${ }^{6} .404 / 76$ prevê que o administrador de companhia aberta deve guardar sigilo sobre qualquer informação não divulgada ao mercado, que possa influir na cotação dos valores mobiliários, vedando a este a utilização da informação para obter, para si ou para outrem, vantagem mediante compra ou venda de valores mobiliários. O $\S 4^{\circ}$ do mesmo artigo 155 detalha esta vedação de utilização de informação relevante, ainda não divulgada, com a finalidade de aferição de vantagem, para si ou para outrem, no mercado de valores mobiliários.
} 
Portanto, alguns casos concretos submetidos aos tribunais dos EUA, mas sob a roupagem do standard of loyalty ${ }^{490}$ podem sugerir referências interpretativas no Brasil.

\subsubsection{CONFLITO DE INTERESSES E TUTELA DO INTERESSE SOCIAL}

O caput do artigo 156 da Lei $\mathrm{n}^{0}$ 6.404/76 prevê que é vedado ao administrador intervir em qualquer operação social em que tiver interesse conflitante com o da companhia, bem como na deliberação que a respeito tomarem os demais administradores, cumprindo-lhe cientificar sobre a existência deste impedimento e adotar medidas para consignar informações sobre este interesse.

O instituto tutelado pelo dispositivo acima é o interesse social, de modo que o artigo 156 reforça o disposto no artigo 154 da Lei $n^{\circ}$ 6.404/76, ambos tendentes a valorizar o fim e o interesse social como ditames de comportamento dos administradores.

Consoante a conceituação emoldurada pela doutrina ${ }^{491}$, o interesse social não é um interesse autônomo e desvinculado dos interesses da pluralidade dos acionistas da companhia, constituindo-se como o interesse comum dos sócios enquanto sócios e não enquanto indivíduos, com enfoque à realização do objeto social.

Partindo deste reconhecimento, o administrador não poderá intervir em operação social em que esteja em posição de conflito de interesses com a companhia, assim como não pode participar de deliberação quando estiver em tal situação. O objetivo do administrador é alcançar o interesse social e não conflitá-lo.

De acordo com Ives Gandra da Silva Martins,

\footnotetext{
490 ALLEN, William T.; KRAAKMAN, Reinier. Commentaries and Cases on the Law of Business Organization. Nova York: Aspen Publishers, 2003, pp. 31; 285 e ss.

${ }^{491}$ LEÃES, Luiz Gastão Paes de Barros. Conflito de interesses e vedação de voto nas assembléias das sociedades anônimas. RDM. São Paulo: Malheiros, n. 92, out./dez, 1993, p. 107.
} 
[t]odos administradores, sejam conselheiros, sejam diretores, têm que se valer dos poderes que a lei e o estatuto lhes atribuem, com olhos fitos no interesse da companhia, interesse que não se restringe apenas à obtenção de lucro imediato, mas também deve compreender o crescimento da empresa e a formação de sólida reputação ${ }^{492}$.

O $\S 1^{\circ}$ do artigo 156 da Lei $n^{\circ}$ 6.404/76 estabelece que o administrador somente pode contratar com a companhia em condições razoáveis e equitativas, idênticas às que prevalecem no mercado ou em que a companhia contrataria com terceiros, sendo que o negócio contratado com infração ao disposto em tal $\S 1^{\circ}$ é anulável e o administrador interessado estará obrigado a transferir para a companhia as vantagens que dele tiver auferido.

As discussões sobre conflitos de interesses da administração sugerem reflexões sobre a contratação entre a companhia e seus administradores, em operações de selfdealing transactions, referidas, entre nós, como negócios consigo mesmo. Não há proibição a estas operações, mas há rigorosos parâmetros para que estas possam ser realizadas regularmente.

A análise da tutela do interesse social pelos administradores é de fundamental importância na adoção de medidas defensivas diante de tentativas de tomada de controle de companhias. Conforme exposto no item 5.2, entendemos que o interesse social é uma das principais balizas para apurar se a medida defensiva está sendo validamente adotada.

\subsubsection{DEVER DE INFORMAR}

O caput do artigo 157 da Lei $\mathrm{n}^{\circ}$ 6.404/76 estabelece que o administrador da companhia aberta deve declarar, ao firmar o termo de posse, o número de ações, bônus de

\footnotetext{
${ }^{492}$ MARTINS, Ives Gandra da Silva; VIDIGAL, Geraldo de Camargo (coord.). Comentários à Lei das Sociedades por Ações. Rio de Janeiro: Forense Universitária, 1999, p. 478.
} 
subscrição, opções de compra de ações e debêntures conversíveis em ações, de emissão da companhia e de sociedades controladas ou do mesmo grupo, de que seja titular.

Esta exigência legal é de grande relevância no que se refere às tomadas de controle por administradores de companhia aberta. A legislação societária, por meio do caput e dos $\S \S 1^{\circ}, 4^{\circ}$ e $6^{\circ}$, adota medidas que reduzem meios para que o administrador possa surpreender aos acionistas e subitamente tomar o controle da companhia, impondo obrigações de informar. A revelação dos administradores sobre suas posições societárias na companhia é também reflexo da lealdade que se espera destes últimos, a teor do artigo 155 da Lei ${ }^{\circ}$ 6.404/76.

O dever de informar estabelecido no artigo 157 da Lei $n^{\circ}$ 6.404/76, regulamentado e detalhado pela Instrução CVM nº 358/02, impõe aos administradores a obrigação de divulgação de informações relevantes a respeito da companhia. A disponibilização informações sobre os negócios da companhia, de modo imediato, completo e adequado, aos acionistas, investidores e público em geral, permite que estes possam realizar juízo próprio sobre manutenção, aquisição ou alienação de valores mobiliários da companhia.

Os administradores de companhias abertas devem comunicar imediatamente à bolsa de valores e a divulgar pela imprensa qualquer deliberação ou fato relevante ocorrido nos seus negócios que possa influir, de modo ponderável, na decisão dos investidores do mercado de vender ou comprar valores mobiliários emitidos pela companhia (artigo 157, $\S 4^{\circ}$, da Lei $\left.n^{\circ} 6.404 / 76\right)^{493}$.

Examinando o tema à luz das defesas contra tomadas de controle, é importante que a administração da companhia forneça amplas informações aos seus acionistas sobre a situação da companhia, do modo a que estes estejam em condições de avaliar se eventual oferta pública que lhes tenha sido feita é adequada e, em tal hipótese, decidir se pretendem

\footnotetext{
${ }^{493} \mathrm{O} \S 5^{\circ}$ do artigo 157 da Lei $\mathrm{n}^{\circ}$ 6.404/76 prevê que os administradores poderão recusar-se a prestar a informação $\left(\$ 1^{\circ}\right.$, alínea e), ou deixar de divulgá-la $\left(\S 4^{\circ}\right)$, se entenderem que sua revelação porá em risco interesse legítimo da companhia, cabendo à Comissão de Valores Mobiliários, a pedido dos administradores, de qualquer acionista, ou por iniciativa própria, decidir sobre a prestação de informação e responsabilizar os administradores, se for o caso.
} 
aceitá-la, rejeitá-la ou coordenar negociação para melhorar os termos e condições ofertados.

A Instrução CVM nº 358/02 regulamenta e detalha o dever de informar, especialmente no que concerne à obrigação dos administradores de companhias abertas de comunicar imediatamente à bolsa de valores e a divulgar pela imprensa qualquer deliberação ou fato relevante ocorrido nos seus negócios que possa influir, de modo ponderável, na decisão de vender ou comprar valores mobiliários emitidos pela companhia (artigo 157, §4 ${ }^{\circ}$, da Lei $\left.n^{\circ} 6.404 / 76\right)^{494}$.

O disposto no artigo 157 da Lei $n^{\circ}$ 6.404/76 tem muitas consequências em relação às medidas defensivas.

Primeiramente, pelo disposto no $\S 1^{\circ}$, a companhia que adote a medida defensiva do pára-quedas dourado (golden parachute) em relação aos seus administradores e profissionais estratégicos deve estar preparada para revelar informações a este respeito quando solicitadas, em assembleia geral ordinária, por acionistas que representem $5 \%$ ou mais do capital social, especialmente quando o pára-quedas dourado (golden parachute) utilizar opções de compra, benefícios ou vantagens, indireta ou complementares, e medidas que repercutam nos contratos de trabalho de tais profissionais, uma vez que estas hipóteses estariam perfeitamente enquadradas nas alíneas “b”, “c” e “d” do $\S 1^{\circ}$ do artigo 157 da Lei $n^{0} 6.404 / 76$.

Adicionalmente, o dever de informar importará em constantes ponderações por parte dos administradores de companhias dotadas de medidas defensivas sobre a necessidade de revelação aos seus acionistas de medidas defensivas adotadas pela companhia, que não sejam tão flagrantes, mas que sejam eficientes no objetivo de dificultar a tomada de controle.

Outro elemento característico é a restrição que o artigo 157 da Lei no 6.404/76 pode impor às operações de $\mathrm{MBO}$, não as proibindo, mas reduzindo o efeito surpresa do qual estas poderiam se valer para aumentar a coerção para a aceitação, pelos acionistas, de eventual oferta pública proposta pelos próprios administradores da companhia.

\footnotetext{
${ }^{494}$ Cf. nota de rodapé n. 493.
} 
A comparação de ordenamentos jurídicos, na disciplina do direito societário, revela a existência de semelhanças básicas entre sistemas legais ${ }^{495}$, assim como aponta características próprias em que não há convergência na regulação.

Em breves lineamentos, pretende-se identificar, no direito comparado, o tratamento jurídico das tomadas de controle, das defesas contra estas e dos modelos de comportamento previstos para a administração das companhias em tais operações.

Essa comparação jurídica adotará como parâmetro, por razões óbvias, o Brasil e delineará, em largas pinceladas, o tratamento do tema em alguns países de tradição anglo-saxã da common law (EUA e Inglaterra) e em alguns países de tradição romanogermânica da civil law (Itália, Alemanha, França e Portugal). Também será abordado o tratamento da matéria na Argentina ${ }^{496}$, que, assim como o Brasil, filia-se à tradição romano-germânica da civil law.

O tratamento legal das tomadas de controle e das defesas a elas oponíveis não é convergente nos países desta comparação jurídica, especialmente no que se refere à admissibilidade das defesas e à expectativa de atuação dos administradores diante de tais operações $^{497}$.

A administração das sociedades norte-americanas tem papel fundamental em processos de tomada de controle, sendo dotadas de ampla liberdade para agir diante de

\footnotetext{
${ }^{495}$ HANSMANN, Henry; KRAAKMAN, Reinier R. What is Corporate Law?. In The Anatomy of Corporate Law - A Comparative and Functional Approach. Oxford: Oxford University Press, 2004, pp. 1-19. Henry Hansmann e Reinier Kraakaman ensinam que há cinco características estruturais semelhantes que usualmente se replicam em sociedades empresárias em diferentes ordenamentos jurídicos, quais sejam: (i) personalidade jurídica; (ii) responsabilidade limitada; (iii) transferibilidade das ações; (iv) administração centralizada em uma estrutura de órgãos; e (iv) propriedade das ações por contribuição de capital.

${ }^{496}$ A escolha da Argentina decorre das estreitas relações de cooperação econômica mantidas com o Brasil, na expectativa de que futuramente reflexões de direito comunitário sobre takeover venham a florescer no Mercosul, ainda que timidamente. É escassa a literatura jurídica específica sobre o tema das tomadas de controle e das medidas defensivas nos países integrantes do Mercosul.

${ }^{497}$ HANSMANN, Henry; KRAAKMAN, Reinier R. The End of History for Corporate Law. Harvard Law School John M. Olin Center for Law, Economics, and Business Discussion Paper Series, n. 280, pp. 20-21, 2000. Disponível em <http://papers.ssrn.com/sol3/papers.cfm?abstract_id=204528>. Acesso em: 12.12.2009.
} 
ofertas públicas, sem a necessidade de autorização específica dos acionistas. Por outro lado, o modelo proposto pela UE assenta-se no reconhecimento de que a reação às tomadas de controle deve competir aos acionistas.

Paul Davies e Klaus Hopt ${ }^{498}$ sustentam que a postura de liberdade à administração, adotada pelos EUA, propicia mecanismos para a ocorrência de abusos e formas de entrincheiramento da administração, revelando que o sistema norte-americano é diferente, até mesmo, daquele adotado na Inglaterra.

Observa-se, assim, que não há homogeneidade nem mesmo entre países filiados à tradição anglo-saxã da common law ${ }^{499}$, cujos mercados de capitais evoluíram e propiciaram a formação de enorme quantidade de companhias com dispersão acionária ${ }^{500}$.

O panorama internacional é fundamental para situar o entendimento da matéria e aferir onde e em que medida o Brasil fixará suas raízes nas vertentes existentes sobre o assunto.

\section{$9.1 \quad$ EUROPA}

Na Europa há um notório esforço de compatibilização legislativa, associado à integração dos países-membros da UE, sob o reconhecimento de que a harmonização legal poderá facilitar, ainda mais, a circulação de riquezas e o desenvolvimento comunitário da atividade empresarial para além dos limites geográficos de cada um dos países-membros

\footnotetext{
${ }^{498}$ DAVIES, Paul; HOPT, Klaus. Control Transactions. In: KRAAKMAN, Reinier et al. The Anatomy of Corporate Law: A Comparative and Functional Approach. Oxford: Oxford University Press, 2004, p. 173.

499 ARMOUR, John; SKEEL, David A. Who Writes the Rules for Hostile Takeovers, and Why? The Peculiar Divergence of Us and UK Takeover Regulation. Georgetown Law Journal. v. 95, p. 1727, 2007; ECGI - Law Working Paper, n. 73, 2006. Disponível em SSRN: <http://ssrn.com/abstract=928928>. Acesso em 12.12.2009; e Idem. The Divergence of U.S. and UK Takeover Regulation. Regulation. v. 30, n. 3, inverno 2007; U of Penn, Inst for Law \& Econ Research Paper No. 08-24. Disponível em SSRN: $<$ http://ssrn.com/abstract=1025986 $>$. Acesso em 12.12.2009.

${ }^{500}$ DAVIES, Paul; HOPT, Klaus. Op. cit., p. 173.
} 
da $U E^{501}$. Há, inclusive, aspiração de formação de um mercado de capitais integrado entre os países-membros da UE.

Recentemente, o grande número de operações de tomada de controle realizadas na Europa concretiza a necessidade de harmonização comunitária sobre a matéria, sobretudo diante do fato de que muitas destas operações vêm sendo realizadas em bases internacionais, envolvendo companhias situadas em diferentes países.

Como exemplos, algumas importantes operações de takeover realizadas na Europa podem ser citadas. Dentre estas, algumas foram realizadas entre companhias localizadas em diferentes países europeus: (i) a oferta pública da Krupp pela Thyssem; (ii) a oferta pública realizada pela Louis Vuitton Moet Hennessey's para aquisição do controle da Gucci, com a Pinault-Printemps-Redoute atuando como cavaleiro branco (white knight); (iii) as ofertas públicas realizadas pelo Banque National de Paris (BNP) para tomada do controle da Paribas e da Societé Generale; (iv) a oferta pública realizada pela Olivetti sobre a Telecom Itália; (v) a oferta pública da Mannesman sobre a Orange; (vi) a oferta pública do Royal Bank of Scotland sobre a Natwest; (vii) a oferta pública da Vodafone Airtouch sobre a Mannesmann; (viii) a oferta pública da Mittal Steel Company sobre a Arcelor S.A., companhia com sede na Holanda, que, no Brasil, era controladora da Arcelor Brasil S.A. e da Acesita S.A. ${ }^{502}$; e (ix) a oferta pública do Royal Bank of Scotland sobre a ABN Amro Holding N.V., companhia com sede na Holanda, que detinha o controle indireto de duas companhias brasileiras: ABN Amro Arrendamento Mercantil S.A. e Real Leasing S.A. Arrendamento Mercantil ${ }^{503}$.

\footnotetext{
${ }^{501}$ WINTER, Jaap W. et al. Report of the High Level Group of Company Law Experts on Issues Related to Takeover Bids in the European Union. Jan. 2002. Disponível em SSRN: <http://ssrn.com/abstract=315322>. Acesso em 12.12.2009.

502 O Colegiado da CVM examinou a operação, no que se refere à necessidade de realização da oferta pública obrigatória, prevista no artigo 254-A da Lei no 6.404/76, para a Arcelor Brasil S.A. e para a Acesita S.A. O Colegiado da CVM entendeu que a oferta pública obrigatória prevista em lei não seria aplicável ao caso, mas consignou necessidade de realização de oferta pública aos acionistas da Arcelor Brasil S.A. em decorrência de previsão estatutária determinando realização de oferta pública caso uma pessoa "adquira o poder de controle da companhia por meio de aquisição de ações de emissão do acionista controlador final da companhia” (CVM, Processo Administrativo RJ-2006-6209, Rel. Dir. Wladimir Castelo Branco Castro, j. 25.09.2006).

${ }^{503}$ Em decorrência de tal oferta pública de aquisição de ações no exterior, que ensejou a mudança do controle da ABN Amro Holding N.V., o Colegiado da CVM apreciou a necessidade de realização, no Brasil, da oferta pública obrigatória, prevista no artigo 254-A da Lei $n^{\circ}$ 6.404/76, em relação à ABN Amro Arrendamento Mercantil S.A. e Real Leasing S.A. Arrendamento Mercantil. O Colegiado da CVM consignou entendimento
} 
Com este ânimo de uniformização legislativa entre os países integrantes da UE, a CE apresentou em 1989 ao Conselho da UE e ao Parlamento Europeu a proposta da $13^{\mathrm{a}}$ Diretriz do Direito das Sociedades, visando a regular as ofertas públicas de aquisição de ações destinadas às tomadas de controle (takeover bids) ${ }^{504}$. Buscava-se assegurar a existência de um ambiente equitativo no tratamento da matéria (level playing field) ${ }^{505}$.

Após conturbado e prolongado processo de regulação comunitária ${ }^{506}$, a proposta da $13^{a}$ Diretriz do Direito das Sociedades resultou na Diretiva ${ }^{\circ}$ 2004/25/CE, que estabelece medidas de coordenação de disposições legislativas, regulamentos e administrativas dos países-membros da UE em relação às ofertas públicas de aquisição de controle, com prazo e disposições quanto à adaptação das legislações nacionais à Diretiva $n^{\circ}$ 2004/25/CE, até 20 de maio de $2006^{507}{ }^{508}$.

A Diretiva $n^{\circ}$ 2004/25/CE estabeleceu princípios gerais a serem observados em oferta públicas destinadas à tomada de controle ${ }^{509}$, tais como: (i) o princípio da igualdade, exigindo tratamento igualitário entre os titulares de valores mobiliários de mesma classe na

pela desnecessidade de realização da oferta pública obrigatória em tal operação (CVM, Processo Administrativo RJ-2007-14099, Rel. Dir. Durval Soledade, j. 29.01.2007).

${ }^{504}$ A Diretiva n ${ }^{\circ}$ 2004/25/CE tem também o condão de evitar escaladas acionárias, prevendo que tomadas de controle realizadas por operação em bolsa de valores se deem, mormente, por ofertas públicas de aquisição de ações. Busca-se assim tratamento igualitário entre os acionistas, sendo este um dos pilares para a proteção aos minoritários visada pela Diretiva nº 2004/25/CE.

${ }^{505}$ A necessidade do ambiente equitativo (level playing field) das tomadas de controle na Europa é até hoje questionada pela doutrina europeia, exemplificativamente: (i) HERTIG, Gérard; McCAHERY, Joseph A. An Agenda for Reform. In: FERRARINI, Guido et al. (org.). Reforming Company and Takeover Law in Europe. Oxford: Oxford University Press, 2004, pp. 21-49; (ii) GORDON, Jeffrey N. An American Perspective on Anti-Takeover Laws in the EU: The German Example. In: FERRARINI, Guido et al. (org.). Reforming Company and Takeover Law in Europe. Oxford: Oxford University Press, 2004, pp. 541-559, também disponível em: < $\underline{\text { http://ssrn.com/abstract=336420 }}$. Acesso em 12.12.2009); e (iii) WINTER, Jaap W. et al. Report of the High Level Group of Company Law Experts on Issues Related to Takeover Bids in the European Union. Jan. 2002. Disponível em SSRN: <http://ssrn.com/abstract=315322>. Acesso em 12.12.2009.

${ }^{506}$ Para maiores detalhes sobre o trâmite da proposta de $13^{\mathrm{a}}$ Diretiva até sua aprovação final na Diretiva $\mathrm{n}^{\mathrm{o}}$ 2004/25/CE, referir-se a (i) OIOLI, Erik Frederico. Oferta Pública de Aquisição de Controle de Companhias Abertas. 2008. Dissertação (Mestrado em Direito Comercial sob orientação do Professor Doutor Erasmo Valladão Azevedo e Novaes França) - Faculdade de Direito, Universidade de São Paulo, São Paulo, 2008, pp. 78-79; e (ii) CORDEIRO, António Manuel da Rocha e Menezes. A $13^{\text {a }}$ Directriz do Direito das Sociedades (ofertas públicas de aquisição). Revista da Ordem dos Advogados. Lisboa, n. 64, 2004, pp. 97111 , mormente nas pp. 98-104.

${ }^{507}$ Artigo 21 da Diretiva $n^{\circ}$ 2004/25/CE.

${ }^{508}$ A Diretiva $n^{\circ}$ 2004/25/CE estabeleceu aos países-membros da UE a obrigação de inserir, até 20 de maio de 2006, os padrões de harmonização em suas respectivas legislações nacionais, realizando as compatibilizações e adequações que fossem julgadas necessárias. O país membro que não ajustasse o direito interno até esta data tornaria a própria Diretiva n ${ }^{\circ}$ 2004/25/CE integralmente aplicável ao seu Direito interno.

${ }^{509}$ Artigo $3^{\circ}$ da Diretiva n ${ }^{\circ}$ 2004/25/CE. 
companhia-alvo; (ii) o princípio da reflexão, prevendo que os acionistas da companhiaalvo disponham de tempo e informações suficientes para decidirem em relação à oferta; (iii) o princípio da isenção, no sentido de que a administração deve ter em conta os interesses da companhia, não podendo impedir os titulares de valores mobiliários de decidirem quanto ao mérito da oferta; (iv) o princípio da verdade do mercado, sustentando que não devem ser criadas demandas artificiais por valores mobiliários dos envolvidos em operações de tomadas de controle; (v) o princípio da operacionalidade, segundo o qual o ofertante só deve anunciar a oferta após assegurar-se de que está em condições de cumprila; e (vi) o princípio da continuidade, no sentido de que a companhia-alvo não deve ser perturbada em decorrência de uma oferta pública por período não razoável ${ }^{510}$.

A Diretiva $n^{0}$ 2004/25/CE expressa a intenção de assegurar aos acionistas da companhia-alvo a decisão quanto à oferta pública que lhes tenha sido realizada, impondo limites à intervenção da administração em tais operações. Para que tal decisão possa ser tomada pelos acionistas, inúmeras proteções são estabelecidas pela Diretiva $n^{\circ}$ 2004/25/CE, especialmente no que tange à divulgação de informações, procedimentos e prazos em relação à oferta pública ${ }^{511}$.

Ocorre que, além das normas de harmonização obrigatórias contidas na Diretiva $n^{\circ}$ 2004/25/CE, há regras de adoção facultativa pelos países-membros, dentre as quais se inserem as relativas às medidas defensivas e aos limites de atuação da administração diante de tentativas de tomada de controle ${ }^{512}$. Como medida de reciprocidade, o país-membro que opte por não adequar sua legislação ao padrão recomendado pela UE, nas normas facultativas, deve permitir sua utilização por sociedades com sede em países que as adotem ${ }^{513}$.

\footnotetext{
${ }^{510}$ A nomenclatura doutrinariamente atribuída a tais princípios gerais é, em nosso vernáculo, obra de António Manuel da Rocha e Menezes Cordeiro. A $13^{\text {a }}$ Directriz do Direito das Sociedades (ofertas públicas de aquisição). Revista da Ordem dos Advogados. Lisboa, n. 64, 2004, pp. 97-111, mormente nas páginas 98 a 104.

${ }^{511}$ Artigos $6^{\circ}, 7^{\circ}$ e $8^{\circ}$ da Diretiva n ${ }^{\circ}$ 2004/25/CE.

${ }^{512}$ O artigo 12 da Diretiva n ${ }^{\circ}$ 2004/25/CE prevê em seu item (1) que "os Estados-Membros podem reservar o direito de não exigir que as sociedades [...], com sede social nos respectivos territórios, apliquem o disposto nos nos 2 e 3 do artigo 9o e/ou no artigo 11”. São, especialmente, no artigo 9o e no artigo 11 que estão as regras de harmonização quanto à utilização de medidas defensivas e à postura da administração diante de tentativas de tomadas de controle.

${ }^{513}$ Artigo 12 da Diretiva no 2004/25/CE item (2).
} 
Dentre os países escopo desta comparação jurídica, Portugal, França Inglaterra e Itália adotaram os padrões sugeridos pelas normas facultativas de harmonização sobre medidas defensivas; diferentemente da Alemanha ${ }^{514}$. Em relação à Itália, as normas foram adotadas com a ressalva de não aplicação em operações internacionais envolvendo sociedades de países que não adotem os referidos padrões harmônicos.

No que tange às regras limitativas à atuação da administração diante de tentativas de tomadas de controle, Portugal, Itália e França adotaram-nas, sendo que a adoção por esta última deu-se com ressalvas a serem tratadas no item 9.1.2.4. A Alemanha, por sua vez ${ }^{515}$, optou por não adotar as regras limitativas à atuação da administração.

Concluindo a breve análise sobre a tão importante Diretiva $n^{\circ}$ 2004/25/CE, destaque-se seu artigo $5^{\circ}$, ao prever a oferta obrigatória como medida de proteção aos acionistas minoritários. Trata-se de oferta pública obrigatória semelhante à legalmente exigida no Brasil pelo artigo 254-A da Lei $n^{\circ}$ 6.404/76 em caso de alienação, direta ou indireta, do controle de companhia aberta ${ }^{516}$, com a ressalva de que os percentuais de participação acionária que determinam a realização da oferta pública são usualmente estabelecidos em 30\%, 25\% e $20 \%{ }^{517}$.

O conteúdo de tal norma comunitária europeia é semelhante àquele das cláusulas de proteção à dispersão acionária adotadas no Brasil, que foram objeto de análise pormenorizada no item 6.2. Talvez, as discussões quanto à $13^{\mathrm{a}}$ Diretriz resultante na Diretiva $n^{0}$ 2004/25/CE, associadas à experiência brasileira com a oferta pública do artigo

\footnotetext{
514 São tratados também, em destaque, a não adoção destas regras pela Holanda e por Luxemburgo, dentre outros países (cf. TOLEDO, Paulo Fernando Campos Salles de. Poison pill: modismo ou solução?. In: CASTRO, Rodrigo R. Monteiro; ARAGÃO, Leandro Santos de [coord.]. Direito Societário: Desafios Atuais. São Paulo: Quartier Latin, 2009, pp. 157-176, especialmente pp. 167-169). Erik Frederico Oioli aponta que a Bélgica também não adotou as normas facultativas (OIOLI, Erik Frederico. Oferta Pública de Aquisição de Controle de Companhias Abertas. 2008. Dissertação (Mestrado em Direito Comercial sob orientação do Professor Doutor Erasmo Valladão Azevedo e Novaes França) - Faculdade de Direito, Universidade de São Paulo, São Paulo, 2008, pp. 91-92). Entretanto, estes países não serão abordados por não estarem compreendidos no escopo de nossa comparação jurídica.

515 Idem nota de rodapé 497.

${ }^{516}$ Sobre comparação entre as mandatory bids previstas no artigo $5^{\circ}$ da Diretiva $n^{\circ}$ 2004/25/CE e as ofertas públicas obrigatórias previstas no artigo 254-A da Lei $\mathrm{n}^{\circ}$ 6.404/76, referir-se a TESTA, Pedro. The Mandatory Bid Rule in the European Community and in Brazil: A Critical View. Ago. 2006. Disponível em SSRN: < http://ssrn.com/abstract=943089>. Acesso em 12.12.2009.

${ }^{517} \mathrm{~A}$ fixação destes percentuais compete aos países-membros em suas legislações nacionais.
} 
254-A da Lei $n^{0}$ 6.404/76, tenham sido a inspiração original das cláusulas de proteção à dispersão acionária largamente utilizadas no Brasil.

Nesse sentido, o item (1) do referido artigo $5^{\circ}$ prevê que os países-membros da UE deverão assegurar que, na hipótese de alguma pessoa, singular ou coletiva, agindo em conjunto ou isoladamente, vir a deter valores mobiliários de uma sociedade para além de determinados limites de percentagem dos direitos de voto ${ }^{518}$, essa pessoa deverá lançar uma oferta pública ${ }^{519}$, por preço equitativo ${ }^{520}$, a fim de proteger os acionistas minoritários dessa sociedade.

Há grande semelhança conceitual entre o conteúdo de tal oferta pública obrigatória e a oferta pública estatutária frequentemente adotada no Brasil em decorrência das cláusulas de proteção à dispersão acionária.

O item (6) do referido artigo $5^{\circ}$ da Diretiva $n^{\circ}$ 2004/25/CE autoriza, ainda, o estabelecimento de outros instrumentos destinados à proteção dos titulares de valores mobiliários, na medida em que estes instrumentos não entravem o desenrolar normal da oferta. A maioria das medidas defensivas adotadas por companhias sediadas em países europeus insere-se neste contexto.

\subsubsection{INGLATERRA}

\footnotetext{
${ }^{518}$ O item (3) do referido artigo $5^{\circ}$ da Diretiva $n^{\circ}$ 2004/25/CE prevê que tal percentagem de direitos de voto e a fórmula do respectivo cálculo são determinados pela regulamentação do Estado-Membro em que se situa a sua sede social.

${ }^{519}$ O item (2) do referido artigo $5^{\circ}$ da Diretiva $n^{\circ}$ 2004/25/CE prevê que o dever de lançar a oferta pública não é aplicável quando o controle tiver sido adquirido na sequência de uma oferta pública voluntária dirigida a todos os titulares de valores mobiliários, para a totalidade das suas participações.

${ }^{520} \mathrm{O}$ item (4) do referido artigo $5^{\circ}$ da Diretiva $n^{\circ}$ 2004/25/CE especifica que preço equitativo será o preço mais elevado pago pelo ofertante por tais valores mobiliários, em período determinado pelos EstadosMembros, não inferior a seis e não superior a 12 meses. Prevê ainda que caso o oferente adquira valores mobiliários acima do preço da oferta, após esta ser tornada pública, o oferente deve aumentar o valor da sua oferta até, no mínimo, o preço mais alto pago pelos valores mobiliários.
} 
A Inglaterra tem grande experiência na regulação das ofertas públicas de aquisição de ações destinadas às tomadas de controle, sendo apontado como o país em que tais ofertas públicas tiveram sua origem ${ }^{521}$.

O regime jurídico inglês pertinente às tomadas de controle é marcado pela flexibilidade do sistema de auto-regulação voluntária estabelecido no City Code. Conforme noticiam Fábio Konder Comparato e Calixto Salomão Filho ${ }^{522}$, o City Code disciplina os takeovers pela via corporativa, sendo elaborado por agentes do mercado de capitais da City de Londres. O cumprimento das regras do City Code é exigido pelo Takeover Panel ${ }^{523}$.

O City Code, desde a sua versão original, proíbe a administração de companhias-alvo de adotar, sem a prévia autorização dos acionistas ${ }^{524}$, medidas defensivas que possam frustrar a oferta de boa-fé. Desta maneira, impossibilita-se a oposição efetiva de uma oferta pública hostil por administradores de companhias inglesas, com vistas a limitar seus poderes em tais operações ${ }^{525}$.

Paul Davies ensina que:

the [City] Code is founded upon two central ideas, both of which are apt to promote the idea of shareholder value, viewed from the perspective of the shareholders of the target company. The two principles are: equal treatment of target shareholders (designed to deal with acquirer opportunism) and the 'non-frustration' rule designed to place the decision on the fate of the bid exclusively in the hands of the shareholders

\footnotetext{
${ }^{521}$ ARMOUR, John; SKEEL, David A. Who Writes the Rules for Hostile Takeovers, and Why? The Peculiar Divergence of Us and UK Takeover Regulation (2007). Georgetown Law Journal. v. 95, p. 1727, 2007; ECGI - Law Working Paper, n. 73, 2006. Disponível em SSRN: <http://ssrn.com/abstract=928928>. Acesso em 12.12.2009.

522 COMPARATO, Fábio Konder; SALOMÃO FILHO, Calixto. O Poder de Controle na Sociedade Anônima. 4. ed. Rio de Janeiro: Forense, 2005, p. 241.

${ }^{523}$ City Panel on Take-overs and Mergers.

${ }^{524}$ FERREL, Allen. Why Continental European Takeover Law Matters. Harvard John M. Olin Center for Law, Economics and Business Discussion Paper, n. 454, p. 11, 2003. Disponível em

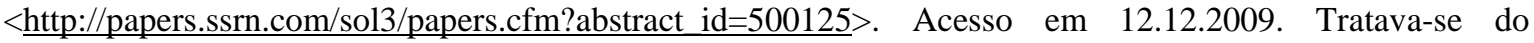
Princípio 7 do City Code. O autor, adiante, destaca que desde então tal princípio é o centro do City Code.

${ }^{525}$ DAVIES, Paul; HOPT, Klaus J. Control Transactions. In: KRAAKMAN, Reinier et al. The Anatomy of Corporate Law: A Comparative and Functional Approach. Oxford: Oxford University Press, 2004, p. 166.
} 
of the target company and to reduce the target management to an information-providing and persuading role ${ }^{526}$.

Observa-se que, no Reino Unido, ao contrário do que ocorre nos EUA, há o reconhecimento expresso de que a decisão quanto às ofertas públicas deve competir aos próprios acionistas, sendo vedado aos administradores intervirem em tais operações tendentes a promover a tomada de controle (non-frustration rule). Esta restrição à atuação da administração em tomadas de controle é a distinção essencial entre os modelos do Reino Unido e dos $\mathrm{EUA}^{527}$.

O City Code teve grande influência na elaboração da $13^{a}$ Diretriz do Direito das Sociedades $^{528}$, que resultou na Diretiva ${ }^{\circ}$ 2004/25/CE. A influência da regulação de takeovers na Inglaterra, país de tradição anglo-saxã da common law, em norma comunitária que seria aplicada por inúmeros países de tradição romano-germânica da civil law suscitou controvérsias e muitas reflexões ${ }^{529}$.

A influência do City Code na versão original proposta para as normas comunitárias era tão expressiva que a doutrina inglesa, à exemplo de Geoffrey Morse, previa o desaparecimento da distinção entre a auto-regulação e as normas jurídicas ${ }^{530}$, com separação das atividades de auto-regulação e julgamento do Takeover Panel ${ }^{531}$ e disciplina de algumas matérias por via legislativa ${ }^{532}$. Embora ainda marcante, esta influência foi suavizada no processo legislativo que culminou na versão final da Diretiva n 2004/25/CE.

\footnotetext{
${ }^{526}$ DAVIES, Paul L. Shareholder Value: Company Law and Securities Markets Law - A British View. Out. 2000. Disponível em SSRN: $<$ http://ssrn.com/abstract=250324>. Acesso em 12.12.2009.

${ }^{527}$ ARMOUR, John; SKEEL, David A. Who Writes the Rules for Hostile Takeovers, and Why? The Peculiar Divergence of Us and UK Takeover Regulation. Georgetown Law Journal. v. 95, p. 1727, 2007; ECGI - Law Working Paper, n. 73, 2006. Disponível em SSRN: <http://ssrn.com/abstract=928928>. Acesso em 12.12.2009; e Idem, David A. The Divergence of U.S. and UK Takeover Regulation. Regulation. v. 30, n. 3 , inverno 2007; University of Pennsylvannia Institute for Law \& Economics Research Paper, n. 08-24.

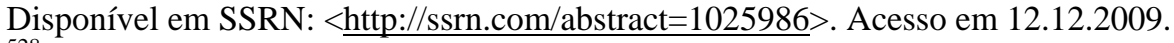

${ }^{528}$ MORSE, Geoffrey. Charlesworth's Company Law. 17. ed. Londres: Sweet \& Maxwell, 2005, p. 676.

${ }^{529}$ TAMBURRINI, Giovanni. Harmonization of Takeover Discipline: A Comparative Law and Economic Overview. 22.06.2009. Disponível em SSRN: <http://ssrn.com/abstract=1423762>. Acesso em 12.12.2009.

${ }^{530}$ MORSE, Geoffrey. Op. cit., p. 674.

${ }^{531}$ O Takeover Panel é o City Panel on Take-overs and Mergers, que tem poderes para exigir o cumprimento das regras do City Code.

${ }^{532}$ MORSE, Geoffrey. Op. cit., p. 676.
} 
As operações de tomada de controle possuem traços característicos e peculiares na Inglaterra, no que se refere, por exemplo, à necessidade de que a oferta pública seja previamente submetida ao conhecimento da administração da companhia-alvo, que, então, informará aos acionistas e ao Takeover Panel sobre a existência da mesma ${ }^{533}$.

Um importante elemento distintivo, a ser considerado nesta comparação jurídica, é o fato de que, diferentemente da maioria dos países da Europa Continental, na Inglaterra predominam companhias abertas com dispersão acionária.

A característica de dispersão acionária na Inglaterra remete à realidade do mercado de capitais nos EUA. Entretanto, diferentemente do que se verifica nos EUA a utilização de medidas defensivas não é frequente na Inglaterra. Allen Ferrel ${ }^{534}$ entende que seria muito difícil articular a utilização, por exemplo, da poison pill no Reino Unido, com base em argumento que não fosse impedir ou bloquear a realização de ofertas públicas indesejáveis. Nesse sentido, complementa o autor dizendo que, até onde é de seu conhecimento, não há casos de utilização da poison pill no Reino Unido.

Portanto, diz-se, resumidamente, que o Reino Unido aborda as tomadas de controle com um “enfoque pró-acionista” ${ }^{535}$, que culmina em restringir a adoção de medidas defensivas e a interferência de administradores em relação às ofertas públicas realizadas, sejam elas amigáveis ou hostis ${ }^{536}$.

\footnotetext{
${ }^{533}$ Conforme OIOLI, Erik Frederico. Oferta Pública de Aquisição de Controle de Companhias Abertas. 2008. Dissertação (Mestrado em Direito Comercial sob orientação do Professor Doutor Erasmo Valladão Azevedo e Novaes França) - Faculdade de Direito, Universidade de São Paulo, São Paulo, 2008, pp. 85-88. ${ }^{534}$ FERREL, Allen. Why Continental European Takeover Law Matters. Harvard John M. Olin Center for Law, Economics and Business Discussion Paper, n. 454, p. 11, 2003. Disponível em $<$ http://papers.ssrn.com/sol3/papers.cfm?abstract id=500125>. Acesso em 12.12.2009.

${ }^{535}$ A referência "pró-acionista" é feita em oposição ao comportamento "pró-administrador", tendo em vista os problemas de agência entre acionistas e administradores nos EUA. A postura adotada pelo Reino Unido é oposta àquela adotada pelos EUA. O termo "postura pró-acionista" é largamente utilizado na doutrina inglesa.

${ }^{536}$ Nas palavras de Allen Ferrel: "[s]ince the promulgation of the City Code in the 1960s, many commentators have noted that a strong culture has developed in the City emphasizing the important role played by shareholders in the running of the corporation, including their right to assess for themselves the merits of a bid" (FERREL, Allen. Op. cit., p. 11).
} 
A maioria dos países da Europa Continental não possui tantas companhias abertas com dispersão acionária quanto, proporcionalmente, possui o Reino Unido.

Este traço distintivo quanto aos mercados de capitais da Europa Continental e do Reino Unido revela, por si só, diferenças de realidade dentro da Europa que sugerem abordagem distinta das tomadas de controle, a qual, conforme exposto ao longo deste trabalho, pressupõe a existência de companhias dotadas de dispersão acionária.

Ao final da década de 1980, à época das discussões iniciais da $13^{\text {a }}$ Diretriz do Direito das Sociedades, que resultou na Diretiva $n^{\circ}$ 2004/25/CE, a experiência europeia em operações de tomada de controle era predominantemente inglesa e o takeover não era um fenômeno usual nos países da Europa Continental ${ }^{537}$, que inclusive questionavam a necessidade de regulação comunitária sobre a matéria ${ }^{538}$.

Por estas razões, a Diretiva $n^{0}$ 2004/25/CE, em alinhamento com o regime britânico $^{539}$, privilegiou a regra da neutralidade da administração em operações de tomada de controle. Na ausência de outras consistentes experiências europeias em takeovers, prestigiou-se o sistema do Reino Unido em oposição à postura dos EUA sobre a matéria, que também servia como paradigma já consolidado à época.

\footnotetext{
${ }^{537}$ Sobre a pouca experiência da Europa Continental, em relação às tomadas de controle, até meados da década de 1990, referir-se a LOPEZ, Ernesto Adolfo Hernandez. Bag Wars and Bank Wars, the Gucci and Banque National de Paris Hostile Bids: European Corporate Culture Responds to Active Shareholders. Fordham Journal of Corporate \& Financial Law. v. 9, n. 1, pp. 127-190, 2003. Disponível em SSRN: $<$ http://ssrn.com/abstract=809985>. Acesso em 12.12.2009. Tal falta de experiência é apontada pelo autor como uma das razões de determinados processos de tomada de controle na Europa Continental terem demorado tempo expressivo para serem concluídos.

${ }^{538}$ TAMBURRINI, Giovanni. Harmonization of Takeover Discipline: A Comparative Law and Economic Overview. 22.06.2009. Disponível em SSRN: $<$ http://ssrn.com/abstract=1423762>. Acesso em 12.12.2009.

${ }^{539}$ GOERGEN, Marc; MARTYNOVA, Marina; RENNENBOOG, Luc. Corporate Governance Convergence: Evidence from takeover regulation. European Corporate Governance Institute Working Paper Series in Law. n. 33, p. 2, abr. 2005. Disponível em <http://papers.ssrn.com/sol3/papers.cfm?abstract_id=709023 $>$. Acesso em 12.12.2009.
} 


\subsubsection{ALEMANHA}

A experiência alemã em relação às tomadas de controle tem evoluído bastante recentemente, como consequência do aumento da exposição de companhias alemãs a este tipo de operação ${ }^{540}$.

A doutrina estrangeira expõe que a resistência da Alemanha em desenvolver um regime jurídico próprio para as ofertas públicas de aquisição de ações também tem fundamento na estrutura de organização societária das sociedades alemãs, marcantemente concentradas e consequentemente invulneráveis às tomadas de controle hostis, mas o caso Vodafone Airtouch vs. Mannesmann despertou a necessidade de regulação germânica desta matéria $^{541}$.

A Alemanha ${ }^{542}$ tem assumido postura própria no tratamento da matéria, erigindo-se como um terceiro modelo de destaque no tratamento da matéria, paralelamente às tradicionais escolas dos EUA e do Reino Unido.

A Alemanha não adotou as regras comunitárias previstas nos artigos $9^{\circ}$ e 11 da Diretiva $n^{\circ}$ 2004/25/CE, que são normas de adoção facultativa pelos países-membros da UE.

A WpÜG ${ }^{543}$, que é a legislação alemã editada sobre tomadas de controle, não incorporou os preceitos da neutralidade da administração (board neutrality) e das regras de suspensão dos efeitos de medidas defensivas (break-trough rule).

\footnotetext{
${ }^{540}$ A oferta pública da inglesa Vodafone Airtouch sobre a alemã Mannesmann, realizada em 1999, tem sido apontada como uma das principais razões para a mudança de postura da Alemanha em relação ao tratamento das takeover bids (cf. JACKSON, Gregory; HÖPNER, Martin. An Emerging Market for Corporate Control? The Mannesmann Takeover and German Corporate Governance. Max-Planck-Institute for the Study of Societies Discussion Paper. n. 01/4, set. 2001. Disponível em: < http://ssrn.com/abstract=285232>. Acesso em 12.12.2009. Neste mesmo sentido, CÂMARA, Paulo. O dever de lançamento de oferta pública de aquisição no direito português. In: WARDE Jr., Walfrido Jorge [coord.]. Fusão, Cisão, Incorporação e Temas Correlatos. São Paulo: Quartier Latin, 2009, p. 394-395.

541 Ibid., p. 394.

${ }^{542}$ Vide nota de rodapé 514, Holanda, Luxemburgo e Bélgica também não adotaram tais normas facultativas.

${ }^{543}$ Para o entendimento adequado do conteúdo do WpÜG referir-se à excelente e objetiva análise realizada por OIOLI, Erik Frederico. Oferta Pública de Aquisição de Controle de Companhias Abertas. 2008.
} 
A legislação alemã autoriza que a administração adote medidas defensivas diante de tentativas de tomada de controle, com a aprovação do Conselho de Supervisão, sem a necessidade de que acionistas autorizem previamente a utilização de tais proteções $^{544}$.

Observa-se na Alemanha forte influência das teorias institucionalistas, presentes em seu sistema jurídico societário, no tratamento legal das tomadas de controle e da admissibilidade de adoção de defesas em oposição a estas, com o delineamento de como deve se comportar os administradores. Em vez de reportarem-se aos acionistas para estarem autorizados a adotar defesas, os administradores submetem-se ao Conselho de Supervisão ${ }^{545}$.

Sabendo que o Conselho de Supervisão das companhias alemãs é integrado não apenas por membros escolhidos pelos acionistas, mas também por integrantes indicados pelos trabalhadores, cabe a este órgão social a coordenação da reação às ofertas públicas tendentes à tomada de controle. Serão avaliados os impactos de tal operação aos trabalhadores, à comunidade em que se insere a companhia-alvo e ao mercado em que esta atua, os acionistas e investidores em geral, em típica concepção institucionalista do interesse social ${ }^{546}$.

Dissertação (Mestrado em Direito Comercial sob orientação do Professor Doutor Erasmo Valladão Azevedo e Novaes França) - Faculdade de Direito, Universidade de São Paulo, São Paulo, 2008, pp. 89-91.

${ }^{544}$ Jeffrey Gordon ensina que a legislação alemã “[...] allows management to take defensive measures merely upon approval of the supervisory board, without first going to shareholders for prior approval. [...] German anti-takeover law has rejected the 'board neutrality'/'shareholders choice' position generally associated with the $13^{\text {th }}$ Directive [...]" (GORDON, Jeffrey N. An American Perspective on Anti-Takeover Laws in the EU: The German Example. In: FERRARINI, Guido et al. [org.]. Reforming Company and Takeover Law in Europe. Oxford: Oxford University Press, 2004, p. 545, também disponível em: $<$ http://ssrn.com/abstract=336420 $>$. Acesso em 12.12.2009).

${ }^{545}$ WpÜG §33 (1), conforme OIOLI, Erik Frederico. Oferta Pública de Aquisição de Controle de Companhias Abertas. 2008. Dissertação (Mestrado em Direito Comercial sob orientação do Professor Doutor Erasmo Valladão Azevedo e Novaes França) - Faculdade de Direito, Universidade de São Paulo, São Paulo, 2008, pp. 90-91.

${ }^{546}$ Para maiores detalhes sobre as teorias institucionalistas na definição do "interesse social", referir-se a FRANÇA, Erasmo Valladão Azevedo e Novaes. Conflito de interesses nas assembléias de S.A. São Paulo: Malheiros Editores, 1993. 
Caso companhias alemãs venham a adotar medidas defensivas de inspiração norte-americana, tal adoção deverá ser submetida a rigorosas adequações ${ }^{547}$, pois os efeitos seriam substancialmente diferentes daqueles obtidos em companhias norte-americanas.

Modesto Carvalhosa ${ }^{548}$ noticia que, na Alemanha, há tendência de oposição à liberdade do mercado de capitais se auto-regular. Segundo o autor, a maior parte das companhias abertas alemãs adota medidas estatutárias de proteção, especialmente a limitação ao número de votos.

É importante ter-se em perspectiva que o país tem observado mudanças de paradigmas, especialmente no que se refere às estruturas de organização do capital em companhias abertas alemãs, e consequentemente há tendência de que as reflexões sobre tomadas de controle e utilização de defesas contra estas últimas tornem-se mais frequentes.

\subsubsection{Portugal}

As regras comunitárias da Diretiva nº 2004/25/CE estão refletidas na legislação portuguesa, inclusive as normas facultativas dos artigos $9^{\circ}$ e 11 da referida diretiva, referentes aos preceitos da neutralidade da administração (board neutrality) e da regra de suspensão dos efeitos de medidas defensivas (break-trough rule).

\footnotetext{
${ }^{547}$ Exemplificativamente, o pára-quedas dourado (golden parachute) teria acepção totalmente distinta na Alemanha. Além disto, os padrões de composição do Conselho de Supervisão e os aspectos legais sobre eleição e destituição de seus membros tornam distinta a aplicação de medidas defensivas atuantes sobre os administradores (GORDON, Jeffrey N. An American Perspective on Anti-Takeover Laws in the EU: The German Example. In: FERRARINI, Guido et al. [org.]. Reforming Company and Takeover Law in Europe. Oxford: Oxford University Press, 2004, p. 553, também disponível em: <http://ssrn.com/abstract=336420>. Acesso em 12.12.2009).

${ }^{548}$ Já na Alemanha, conforme demonstra a história das tentativas de obtenção de controle, a tendência, ao contrário, sempre foi no sentido de reagir contrariamente à liberdade do mercado de se auto-regular. Assim, a maioria das sociedades alemãs adota medidas estatutárias de proteção. A principal delas, e também a mais utilizada, consubstancia-se no Hochstimmrechte, que significa limitar o direito de voto do acionista individual, que, "independentemente do número de ações possuídas, não tem direito em geral a representar mais que 5\% do capital votante nas Assembléias Gerais” (CARVALHOSA, Modesto. Comentários à Lei de Sociedades Anônimas. v. 4, t. II, 2. ed. rev. e atual. São Paulo: Saraiva, 2003, p. 216). Isso aumenta a importância dos pequenos acionistas, e dos bancos, tradicionais depositários de suas ações, que por eles votam nas assembleias ( $\$ 135$ da AktG).
} 
Em Portugal, vigora o princípio da abstenção da administração, à qual se veda a prática de "atos susceptíveis de alterar de modo relevante a situação patrimonial da sociedade visada que não se reconduzam à gestão normal da sociedade e que possam afetar de modo significativo os objetivos anunciados pelo oferente” ${ }^{\text {549 }}$. Luis Manuel Teles de Menezes Leitão ensina que a limitação ao uso de medidas defensivas pela administração é expressa ${ }^{550}$, especialmente em relação àquelas posteriores, que não podem ser adotadas sem o consentimento dos acionistas ${ }^{551}$.

Durante o processamento da oferta pública, a administração deve "agir de boafé, designadamente quanto à correção das informações e quanto à lealdade do

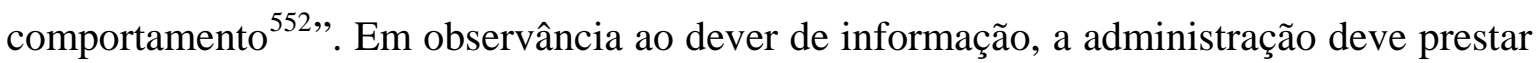
esclarecimentos aos acionistas interessados na alienação de suas ações, enquanto pelo dever de lealdade os administradores não podem adotar nenhuma medida destinada à deterioração de posições a serem adquiridas ${ }^{553}$.

António Menezes Cordeiro explica que a maioria das regras da Diretiva $\mathrm{n}^{\mathrm{o}}$ 2004/25/CE já estavam consagradas no direito português, particularmente no Código de Valores Mobiliários editado em $1999^{554}$. Consequentemente, a norma comunitária não suscitou muitos acréscimos ao direito português, somente no que se refere às informações que devem ser prestadas aos trabalhadores durante a oferta pública ${ }^{555}$.

\footnotetext{
${ }^{549}$ Código de Valores Mobiliários (Portugal), artigo 182.\%1. No artigo 182.\%/2 b prevê-se que são consideradas alterações relevantes da situação patrimonial da companhia-alvo a emissão de ações ou de outros valores mobiliários que confiram direito de subscrição ou aquisição e a celebração de contratos que visem a alienação de parcelas significativas do ativo.

${ }^{550}$ No prazo de 8 dias do recebimento do projeto de anúncio de lançamento da oferta de aquisição, a administração da companhia-alvo deve enviar ao ofertante e à Comissão do Mercado de Valores Mobiliários e publicar relatório a respeito da conveniência e das condições da oferta (Código de Valores Mobiliários (Portugal), artigo 181.\%1.), quando poderá verificar-se se a oferta é amigável ou hostil (CORDEIRO, António Manuel da Rocha e Menezes. Manual de Direito das Sociedades: das sociedades em especial. v. 2, 2. ed. rev. e atual. Coimbra: Almedina, 2007, p. 656).

${ }^{551}$ LEITÃO, Luís Manuel Teles de Menezes. As medidas defensivas contra uma oferta pública de aquisição hostil. O Direito. Ano 138, t. III, Coimbra: Almedina, 2006, pp. 468-472.

552 Código de Valores Mobiliários, artigo 181.\%/2, d.

${ }^{553}$ CORDEIRO, António Manuel da Rocha e Menezes. Ofertas Públicas de Aquisição. ROA, Lisboa, n. 56, 1996, pp. 512-513. Como observa Menezes Cordeiro, os deveres de informação e lealdade são concretizações do princípio da boa fé.

${ }^{554}$ Idem. A $13^{\text {a }}$ Directriz do Direito das Sociedades (ofertas públicas de aquisição). ROA. Lisboa, n. 64, 2004, pp. 97-111, especialmente p. 111.

${ }^{555}$ Idem. Direito Europeu das Sociedades. Coimbra: Almedina, 2005, p. 527. O doutrinador português chama atenção, no entanto, para o fato de que o prazo disponibilizado para transposição da diretriz podia ser usado para reflexão a respeito da complexidade excessiva do direito mobiliário português. Segundo ele, as regras e
} 


\subsubsection{ITÁLIA}

As regras comunitárias da Diretiva nº 2004/25/CE estão refletidas na legislação italiana, inclusive as normas facultativas dos artigos $9^{\circ}$ e 11 da referida diretiva, referentes aos preceitos da neutralidade da administração (board neutrality) ${ }^{556}$ e das regras de suspensão dos efeitos de medidas defensivas (break-trough rule) ${ }^{557}$.

As ofertas públicas de aquisição de ações estão reguladas na Itália pelo TUF ${ }^{558}$, sendo ainda regradas pelo Regulamento n 11520/1998 da Consob.

A administração de companhias italianas não pode praticar atos ou operações que tenham por objetivo obstaculizar a oferta de aquisição, inclusive adotando medidas defensivas, sem a prévia autorização dos acionistas, em assembleia geral ${ }^{559}$. Exige-se voto favorável de acionistas que representem, no mínimo, 30\% do capital social para utilização de defesas contra a oferta pública ${ }^{560}$, pautando-se os administradores pelos deveres legais que lhes são impostos sob pena de serem responsabilizados pelos atos praticados ${ }^{561}$.

Em 2004, por meio do Decreto Legislativo $n^{\circ} 37 / 2004$, passou a ser admitida a emissão de ações com direito de voto subordinado à efetivação de oferta de aquisição. Trata-se de clássica medida defensiva, tendente a transformar em votantes ações sem

procedimentos sobre operações em mercado de capitais em Portugal são muito mais complexos do que na maioria dos países da Europa.

${ }^{556}$ FERRARA JR., Francesco; CORSI, Francesco. Gli Imprenditori e Le Società. 13. ed. Milão: Giuffrè, 2006, p. 864.

${ }^{557}$ Vide nota de rodapé n. 447. Segundo Paulo Fernando Campos Salles de Toledo, o item (2) do artigo 104bis do TUF prevê que "não têm efeito, no período de adesão à oferta pública, as restrições estatutárias à transferência de títulos, nem, na assembléia convocada para decidir a respeito de eventuais medidas defensivas, as limitações a direito de voto constantes do estatuto ou de acordo de acionistas”. O jurista complementa esclarecendo que a restrição quanto ao voto plural não foi acolhida na Itália, uma vez que este não é admitido na Itália em qualquer caso, a teor do artigo 2.351 do Código Civil Italiano (TOLEDO, Paulo Fernando Campos Salles de. Poison pill: modismo ou solução? In: CASTRO, Rodrigo R. Monteiro; ARAGÃO, Leandro Santos de (coord.). Direito Societário: Desafios Atuais. São Paulo: Quartier Latin, 2009, pp. 157-176, especialmente p. 167-169).

${ }_{558}$ Notadamente nos artigos. 102 e seguintes do TUF.

${ }^{559}$ FERRARA JR., Francesco; CORSI, Francesco. Op. cit., p. 864.

${ }^{560}$ Artigo 104 do TUF.

${ }^{561}$ AULETTA, Giuseppe; SALANITRO, Niccolò. Diritto Commerciale. 15. ed. Milão: Giuffrè, 2006, p. 259. 
direito de voto tão logo estas sejam submetidas à tentativa de tomada de controle. De um lado, aumenta-se a quantidade de ações que deverão ser adquiridas para que o ofertante assuma o poder de controle na companhia e, de outro, reforçam-se as posições acionárias dos detentores de tais ações não votantes, que adquirirem direito de voto. O dispositivo tem suscitado muitas controvérsias na Itália e sua redação tem sido criticada pela doutrina italiana ${ }^{562}$.

\subsubsection{FRANÇA}

A França segue as regras comunitárias da Diretiva n 2004/25/CE, inclusive no que tange às normas facultativas dos artigos $9^{\circ}$ e 11 da referida diretiva, sobre neutralidade da administração (board neutrality) ${ }^{563}$ e suspensão dos efeitos de medidas defensivas (break-trough rule) ${ }^{564}$.

Philippe Merle ${ }^{565}$ ensina que, em grande parte, a regulamentação francesa da matéria já estava adequada às orientações e às regras da Diretiva nº 2004/25/CE.

De acordo com o artigo 3.2 do Regulamento 89/03 da COB, durante a pendência da oferta pública, o ofertante e a companhia-alvo devem assegurar que todos os seus atos, decisões e informações não tenham por efeito comprometer o interesse social e a igualdade de tratamento ou de informação dos destinatários da oferta. Em relação à posição dos administradores, o referido dispositivo legal prevê que, caso a administração queira praticar ato estranho ao curso normal dos negócios da companhia, a autoridade de supervisão deverá ser avisada de modo a assegurar o controle das informações prestadas ao público.

\footnotetext{
${ }^{562}$ FERRARA JR., Francesco; CORSI, Francesco. Gli Imprenditori e Le Società. 13. ed. Milão: Giuffrè, 2006, pp. 864-865.

563 Ibid., p. 864.

${ }^{564}$ Vide nota de rodapé $\mathrm{n}^{0} 557$.

565 MERLE, Philippe. Droit commercial: sociétés commerciales, 10. ed. Paris: Dalloz, 2005, p. 793.
} 
A doutrina francesa ${ }^{566}$ consigna que, embora seja possível a utilização de medidas defensivas naquele país, este uso submete-se a inúmeras restrições. Quando utilizadas, as defesas caracterizam-se como estratégias diversas com o objetivo de manter poder de controle sobre o capital social da companhia e práticas tendentes a encarecer o custo da operação de tomada de controle ${ }^{567}$.

Modesto Carvalhosa, analisando a abordagem da França em relação às tomadas de controle e defesas opostas contra estas últimas, instrui que:

[...] na França toleram-se, durante o período da oferta, alterações estatutárias que criam o voto duplo ou uma limitação dos direitos de voto das ações já emitidas, objeto da oferta pública. Admite-se, ainda, na prática francesa, a emissão de certificados de investimentos ou ações com dividendos prioritários sem voto. Ainda ali verifica-se, durante o período da oferta pública, a transformação da companhia em comandita por ações. Também se tolera o aumento do capital da companhia, por delegação da assembléia geral, o que se tornou possível no curso da oferta pública depois da vigência da lei de 2 de agosto de 1989 (que dá nova redação ao art. 180da lei de 24-7-1966): 'a condition que l'eventualité d'une offre ai été expressment prevue et qu'il ne agisse pás d'une emission reserve, ${ }^{\text {, }}{ }^{\text {a }}$.

Parece-nos que estas considerações são anteriores às adequações pertinentes à harmonização sugerida pela Diretiva n 2004/25/CE, que tem como uma de suas premissas a vedação ao voto plural em observância às break-trough rule, que vigorarão durante o período de aceitação da oferta pública.

Sobre a experiência francesa, destaque-se que a primeira operação de takeover lá realizada ocorreu em 1968, na oferta pública lançada pela Société Boussois-SouchonNeuvesel - BSN sobre a Compagnie Saint Gobain ${ }^{569}$, propondo permuta de ações da Saint

\footnotetext{
${ }^{566}$ MERLE, Philippe. Droit commercial: sociétés commerciales, 10. ed. Paris: Dalloz, 2005, p. 793.

${ }^{567}$ Ibid., pp. 804-807.

${ }^{568}$ CARVALHOSA, Modesto. Comentários à Lei de Sociedades Anônimas. v. 4, t. II, 2. ed. rev. e atual. São Paulo: Saraiva, 2003, p. 266.

${ }^{569}$ MERLE, Philippe Merle. Droit commercial: sociétés commerciales, 10. ed. Paris: Dalloz, 2005, p. 791. Para estudo mais detalhado do caso, ver HIRIGOYEN, Gérard. Brief History of the B.S.N.: Saint-Gobain Takeover Attempt. dez. 1968 / jan. 1969. Disponível em < http://ssrn.com/abstract=144768>. Acesso em 12.12.2009.
} 
Gobain por debêntures conversíveis em ações da BSN. À época, Fábio Konder Comparato $^{570}$ examinou a operação que sugeria o estudo das ofertas públicas (takeover bids) na Europa Continenal.

\subsection{Estados Unidos DA AMÉRICA}

Os EUA são o grande palco das reflexões jurídicas sobre as ofertas públicas para aquisição de controle, referidas como tender offers, e as defesas oponíveis às tentativas de tomada de controle.

Conforme exposto no histórico do item 4.2, as tender offers desenvolveram-se nos EUA de maneira expressiva e assumiram relevo na doutrina e na jurisprudência, especialmente a partir década de 1980, como reflexo jurídico do fenômeno econômico cada vez mais frequente das tomadas de controle de companhias dotadas de dispersão acionária, por meio de tender offers.

A doutrina norte-americana expõe que, até a década de 1960, a maioria das operações amigáveis de tomada de controle de companhias abertas era realizada por meio de permuta, observando rigorosas exigências do Securities Act de 1933 e requerendo registro perante a SEC. Quando tais operações eram realizadas de forma hostil, as batalhas por procurações para representação em Assembleias Gerais (proxy fights) eram o método mais frequente, mas eram criticadas por demandarem muito tempo para serem implementadas, pela imprevisibilidade a elas associada e pela alta regulação a que se submetiam, em decorrência das regras de solicitação de procuração previstas no Securities and Exchange Act de 1934.

A partir da década de 1960 as tender offers tornaram-se métodos frequentes nas operações de tomada de controle realizadas nos EUA ${ }^{571}$, valendo-se, na maioria dos casos, da forma abusiva das two-tier takeover, que eram operações de tomada de controle

\footnotetext{
${ }^{570}$ Para maiores detalhes referir-se à obra de COMPARATO, Fábio Konder. 'Take-over bids' ou a desforra do acionista. In: _. . Aspectos Jurídicos da Macro-Empresa. São Paulo: RT, 1970, pp. 38-41.

${ }^{571}$ Refira-se às exposições sobre as Saturday Night Special contidas no item 4.2 deste trabalho.
} 
conjugando uma oferta pública de aquisição de ações representativas do controle da companhia-alvo seguida de: (i) oferta pública de aquisição de ações por valor significativamente menor do que aquele oferecido na oferta pública, por meio da qual se adquiriu o controle; ou (ii) operação de incorporação da companhia-alvo em outra companhia.

Diante da grande quantidade de tomadas de controle mediante tender offers, advogados e profissionais de mercado desenvolvem estratégias defensivas contra tais operações, especialmente protegendo-se de métodos abusivos como aqueles perpetrados pelas two-tier takeovers.

Paralelamente a isto, os EUA adotam o Williams Act de $1968^{572}$, que era uma legislação federal alterando parcialmente o Securities Exchange Act de 1934, visando a principalmente evitar abusos em operações de tomada de controle, reduzindo a pressão imposta aos acionistas da companhia-alvo de aderirem à oferta pública, assegurando regras sobre prazo de aceitação da oferta pública, exigindo prestação de informações e amplo disclosure em tais operações.

Originalmente, o Williams Act aplicava-se apenas às ofertas públicas para aquisição de controle realizadas para pagamento em dinheiro, as quais até então não eram reguladas. Posteriormente, o referido diploma foi expandido para incluir todas as ofertas públicas de aquisição de controle.

Em sua proposta original, o Williams Act previa a adoção de inúmeras regras restritivas às ofertas públicas de aquisição de ações. Entretanto, após revisões às quais a versão inicial foi submetida, o diploma acabou tornando-se uma legislação preponderantemente destinada à divulgação de informação, em vez de um ordenamento restritivo às tomadas de controle. O Williams Act obteve sucesso na redução de abusos pertinentes às tomadas de controle, propiciando meios, entretanto, para que tais operações não deixassem de existir.

\footnotetext{
${ }^{572}$ Para maiores informações, refira-se às nossas notas de rodapé 138 e 139 e à explanação dos doutrinadores norte-americanos Jesse Chopper; John Coffee e Ronald Gilson (Cases and Materials on Corporations. 7. ed. Nova York: Aspen Publishers, 2008, notadamente o Capítulo IX “E” - Federal Regulation of Takeover, pp. 1076-1088).
} 
As ofertas públicas hostis para tomada de controle continuaram sendo uma operação que sugeria alerta constante das companhias dotadas de dispersão acionária. Por conta disto, a criatividade desenvolveu inúmeras espécies de medidas defensivas, tendo as mais emblemáticas destas sido examinadas neste trabalho.

Nos EUA, as medidas defensivas são amplamente admitidas e a administração tem papel fundamental diante de tentativas de tomadas de controle. Inúmeros julgados e precedentes, especialmente da Suprema Corte de Delaware, desenvolveram os modelos de conduta (models of conduct) e os padrões de revisão (standards of review), que examinamos no item 8.1 deste trabalho.

Os modelos de conduta (models of conduct) delineiam a atuação dos administradores diante de tentativas de tomada de controle, com base em deveres gerais impondo prestação, ativa ou omissiva, aos administradores. Os padrões de revisão (standards of review) são amparos usualmente utilizados pelos tribunais na interpretação de casos de tomadas de controle.

Com base nestes parâmetros de flexibilidade estabelecidos em decorrência de casos concretos, pode-se dizer que nos EUA o regime de tratamento legal das operações de tomada de controle é tendente a autorizar medidas defensivas e interferência de administradores em tais operações, sendo certo que distorções e disfunções devem ser corrigidas de acordo com os padrões legais locais.

Entretanto, deve-se esclarecer que a matéria é tratada de forma distinta nas legislações próprias de cada estado norte-americano. Jesse Choper, John Coffee Jr. e Ronald Gilson explicam que as legislações estaduais destinadas a regular as tentativas de tomada de controle enquadravam-se em duas gerações.

Em meados de 1970, os estados norte-americanos começaram a adotar ordenamentos contra as tomadas de controle (anti-takeover statutes), na chamada primeira geração de legislações estaduais. A maioria de tais legislações estaduais inspirava-se no modelo do Estado de Illinois (Illinois Business Takeover Act). Entretanto, este diploma legal veio a ser declarado inconstitucional pela Suprema Corte dos EUA, em 1982, sob o 
entendimento de que violava o principio constitucional americano da liberdade do comércio $^{573}$.

Em seguida, surgiram os ordenamentos contra tomadas de controle (antitakeover statutes) de segunda geração, com destaque ao modelo do Estado de Indiana (Indiana Control Share Acquisition Statute), estruturalmente replicado por outros estados norte-americanos, como Nova Iorque e Nova Jersey. A Suprema Corte dos EUA, em 1987, reconheceu a validade do ordenamento anti-takeover adotado pelo Estado de Indiana ${ }^{574}$.

Após tal decisão da Suprema Corte dos EUA, inúmeros estados norteamericanos estabeleceram algum ordenamento anti-takeover, sendo que o estado da Pensilvânia proibiu a realização de ofertas hostis e previu a OPA obrigatória (mandatory bid), estabelecendo que o adquirente de $30 \%$ ou mais das ações de uma companhia constituída naquele Estado é obrigado a adquirir as ações dos demais acionistas ${ }^{575}$.

\subsection{ARgENTINA}

Na Argentina, as ofertas públicas de aquisição de ações estão previstas na Ley de Sociedades Comerciales e é regulada por Resoluções da $\mathrm{CNV}^{576}$.

O mercado de capitais argentino ainda se encontra em estágio de evolução anterior ao brasileiro. Não há quantidade expressiva de companhias abertas argentinas com valores mobiliários efetivamente negociados no mercado de capitais, que ainda não experimentou a evolução observada no Brasil nos últimos anos, especialmente a partir de 2004.

\footnotetext{
${ }^{573}$ Edgard v. MITE Corp. (457 US 624, Suprema Corte dos Estados Unidos, 1982, Rel. Byron R. White).

${ }^{574}$ CTS Corp. v. Dynamics Corp. of America (481 US 69, Suprema Corte dos Estados Unidos, 1987, Rel. Lewis Powell). Para maiores detalhes, referir-se a CHOPER, Jesse H.; COFFEE, John C.; e GILSON, Ronald J. Cases and Materials on Corporations. 7. ed. Nova York: Aspen Publishers, 2008, p. 944.

${ }^{575}$ Ibid., p. 944.

${ }^{576}$ A oferta pública de aquisição está tratada nas Resoluções CNV no 61/80, no 63/81, no 110/87, nº 190/92 e $n^{\circ} 204 / 92$.
} 
Em decorrência deste estágio preliminar do mercado de capitais, operações de tomada de controle são estranhas à prática argentina, mas já vêm sendo estudadas pela doutrina local, inclusive no que se refere às medidas defensivas e à postura da Argentina diante deste fenômeno, com base em comparações relativas aos modelos dos EUA, do Reino Unido e da Europa Continental.

Mariano Gagliardo e Juan Martín Odriozola posicionam-se favoravelmente à adoção de medidas defensivas na Argentina ${ }^{577}$. Mariano Gagliardo, inclusive, exemplifica algumas espécies de medidas defensivas que poderiam ser validamente adotadas na Argentina $^{578}$.

Juan Martín Odriozola ${ }^{579}$, após abordar o tratamento das tomadas de controle nos EUA e na Europa, inclusive no que se refere às espécies de medidas defensivas vigentes adotadas em tais localidades e fazer breves considerações sobre o perfil de comportamento da administração diante de tais operações, sustenta que a realidade da Europa Continental é mais semelhante à Argentina do que a experiência dos EUA.

577 GAGLIARDO, Mariano. Toma de Control Societario y Medidas Defensivas. Buenos Aires: Ad-Hoc, 1993, especialmente nas pp. 85-121; ODRIOZOLA, Juan Martín. Compraventa Accionaria y Take over: la función profesional. In: ___ Negocios Parasocietarios. Buenos Aires: Ad-Hoc, 1994, pp. 159-173.

${ }^{578}$ Mariano Gagliardo refere-se (i) às cláusulas de limitação da transmissibilidade de ações; (ii) aos contratos parasociais (referidos como sindicación de acciones); (iii) ao aumentos de quorum de deliberação em assembleias; (iv) ao aumento de capital diferido; (v) à emissão de obrigações negociáveis; (vi) aos bônus de gozo e participação (referidos como bonos de goce y participación); (vii) ações sem direito de voto; (viii) sociedade de investimentos, inclusive holdings; (viii) emissão de ações com direito de voto plural; (ix) cessão de ativos; (x) aquisição pela companhia das ações de sua própria emissão; (xi) reorganização ou reestruturação societária; (xii) apoio dos administradores; (xiii) renovação parcial do Conselho de Administração (renovación parcial del directorio), em alusão semelhante ao staggered board da experiência dos EUA, que no caso norte-americano refere-se ao Conselho de Administração e não há Diretoria, como se dá na hipótese concebida em relação à Argentina) (conforme GAGLIARDO, Mariano. Op. cit., pp. 85-121). Registre-se que, embora referidas como medidas defensivas pelo respeitável autor argentino, a maioria dos institutos jurídicos referidos não é propriamente medidas defensiva, mas sim instrumento destinado à consolidação do poder de controle em companhias. As medidas defensivas são proteções utilizadas por companhias dotadas de dispersão acionária ou com expectativas de migrarem para a dispersão acionária. A companhia com concentração acionária sequer é objeto das ofertas públicas de ações visando a adquirir em operação pública ações em quantidade suficiente para assegurar o controle.

${ }^{579}$ ODRIOZOLA, Juan Martín. Op. cit.. Além disso, de maneira técnico-conceitual mais adequada do que Mariano Gagliardo, Juan Martín Odriozola aponta medidas defensivas com características semelhantes às autorizadas na França como passíveis de adoção na Argentina, referindo-se à "terra arrasada”, à contra-OPA sobre o ofertante (“defesa pac-man”) e à OPA concorrente (“cavaleiro branco”), nesta última abordando a hipótese de realização pelos próprios administradores, o que caracterizaria um MBO. 
Da breve abordagem realizada em relação à Argentina, nota-se que a matéria está mais amadurecida no Brasil, tanto sob o aspecto jurídico quanto pela necessidade econômica da utilização do instituto da oferta pública e dos consentâneos ao mesmo. 


\section{CONCLUSÃO}

A proliferação, no estrangeiro, das companhias dotadas de dispersão acionária e, aos poucos, o aumento da quantidade de companhias abertas com estas características no Brasil têm suscitado importantes reflexões acerca da aplicação, entre nós, de fenômenos econômicos de efeitos jurídicos observados na experiência internacional, tais como as tomadas de controle.

As reflexões pertinentes às tomadas de controle, que potencialmente ocorrem por meio de ofertas públicas voluntárias para a aquisição de ações, afloram a necessidade do desenvolvimento de padrões nacionais em relação à admissibilidade de utilização de medidas defensivas, preventivas e/ou posteriores, em oposição à ameaça representada pelas tomadas de controle.

Nesse mesmo compasso, é necessário o delineamento de alguns matizes de comportamento em relação à postura a ser adotada pelos administradores de companhias abertas brasileiras diante de eventual tentativa de tomada de controle destas últimas.

A abordagem do direito comparado em relação à matéria revela a existência de modelos distintos, com destaque ao modelo dos EUA e ao do Reino Unido, este último exercendo forte influência na definição do modelo dos países-membros da UE.

Dentre os países-membros da UE, em decorrência da não adoção por todos das normas facultativas da Diretiva $n^{\circ}$ 2004/25/CE, também não há um padrão homogêneo no tratamento da matéria, destacando-se, exemplificativamente, a Alemanha dentre os países que se opuseram às regras de neutralidade da administração (board neutrality) e suspensão dos efeitos de medidas defensivas durante ofertas públicas (break-trough rule). Portanto, a complexidade do tema é confirmada pelos distintos posicionamentos dos países no tratamento da matéria.

De nossa parte, atenção especial é dedicada especificamente à abordagem das medidas defensivas contra as tomadas de controle, inclusive delimitando a postura a ser 
adotada pelo nosso país diante desta matéria, na interpretação da mesma em âmbito judicial e administrativo, especialmente pela CVM.

No Brasil, parece-nos que não nos filiaremos integralmente a nenhum dos modelos existentes, sob o entendimento de que o nosso ordenamento jurídico possui características próprias de combinação da tradição romano-germânica da civil law, que é a nascente do nosso Direito, com influências da tradição anglo-saxã da common law, sobretudo em nosso direito societário e do mercado de capitais.

As tomadas de controle e a expectativa de desenvolvimento do mercado para o controle societário (market for corporate control) a elas associado podem trazer efeitos extremamente benéficos para o Brasil, fomentando ainda mais a expansão e desenvolvimento do nosso mercado de capitais, que nos últimos anos vem apresentando significativo crescimento.

A definição de padrões extremos, em bases defensivas intransponíveis, não nos parece ser a medida certa. Entretanto, a total liberdade à proliferação de tomadas de controle pode propiciar meios para a prática reiterada de abusos. A este respeito, podem-se extrair conceitos da experiência dos EUA a partir da década de 1980, inspirando as delimitações a serem feitas em relação às características das ofertas públicas.

Ocorre que, em relação às ofertas públicas, a Instrução CVM nº 361/02 já contempla um eficiente sistema de freios e contrapesos, que certamente poderá ser aperfeiçoado com as necessidades que se colocarem. Em relação à postura dos administradores diante de tais operações, parece-nos que a nossa festejada Lei $n^{\circ}$ 6.404/76 também já estabelece pedagogicamente os parâmetros que devem orientar a atuação dos administradores, na certeza de que a interpretação casuística daqueles dispositivos conduzirá a características próprias no tratamento da matéria.

Sendo assim, dentre os pontos de maior reflexão pertinentes às tomadas de controle, as medidas defensivas parecem ser aqueles mais carecedores de atenção do legislador e dos órgãos de fiscalização do mercado de capitais nacional. A Audiência Pública $n^{\circ}$ 03/2009, que resultou na edição do Parecer de Orientação $n^{0} 36 / 2009$, criou 
expectativas de que a CVM se posicionaria sobre a matéria, fornecendo valiosos parâmetros e balizamentos, mas a questão foi enfrentada de forma superficial.

A insuficiência de regulação sobre as medidas defensivas às tomadas de controle é um aspecto para reflexão diante do cenário de tendente aumento da dispersão do capital acionário brasileiro.

Reconhecemos a importância do posicionamento da CVM sobre a matéria e, quiçá, da própria regulação com alguns delineamentos genéricos sobre a utilização de medidas defensivas no Brasil. Opomo-nos à intervenção rigorosa no tema, que é assaz complicado e suas variáveis somente podem ser integralmente compreendidas nos casos concretos. Porém, entendemos que a ausência completa de regulação sobre a matéria é uma falta de balizamento perigosa, que pode colocar em risco as companhias que, migrando para estruturas de dispersão acionária, utilizem medidas defensivas sem saber os limites de adoção das mesmas.

No Brasil, parece-nos que a regulação das medidas defensivas deverá ser norteada pelo equilíbrio entre os princípios que guiaram a questão na jurisprudência norteamericana e as orientações da UE aos seus países-membros na regulação da matéria.

Não parece ser conveniente deixar essa questão inteiramente a critério de cada companhia. O legislador e/ou a CVM precisam discipliná-la, ao menos em suas grandes linhas, uma vez que, colocadas em prática as medidas defensivas, certamente irão advir divergências, cuja solução requererá um norteamento legal.

Atualmente, observa-se no Brasil a adoção de medidas defensivas típicas de ordenamentos jurídicos de outros países, especialmente aqueles utilizados nos EUA, que vêm sendo transplantados para o nosso sistema jurídico, sem o adequado exame de admissibilidade e sem a necessária ponderação quanto à adequação de tais mecanismos às características próprias do nosso sistema legal. Além disso, na maioria dos casos, as medidas defensivas são utilizadas por companhias sem dispersão acionária e sem o devido entendimento da extensão e efeitos decorrentes da utilização destas proteções.

O exame de admissibilidade de utilização das medidas defensivas no Brasil é atribuição dos aplicadores do Direito e, para isto, parece-nos que os instrumentos 
necessários já se encontram disponíveis em nossa legislação, principalmente no Código Civil e na Lei ${ }^{0}$ 6.404/76. Adicionalmente a estes parâmetros, devem ser associados os deveres legais atribuídos aos administradores de companhias, pois, na maioria dos casos, são estes que adotarão as defesas, especialmente aquelas posteriores à existência da tentativa concreta de tomada de controle.

Nessas reflexões, será valiosa a catalogação técnico-conceitual proposta para as medidas defensivas, segundo os critérios do momento em que tais defesas são estabelecidas ou praticadas (medidas defensivas preventivas vs. posteriores) e a natureza jurídica dos instrumentos utilizados para o estabelecimento ou prática das medidas defensivas (medidas defensivas estatutárias vs. contratuais vs. institucionais).

Os critérios referidos nortearão, respectivamente, a extensão da responsabilidade dos administradores de companhias, quanto à utilização das mesmas, e a análise da validade das medidas defensivas.

De maneira sumária, estas são as nossas considerações finais sobre a utilização no Brasil de proteções contra tomadas de controle hostis de companhias abertas brasileiras, com a proposta de que os elementos importados ao Brasil devem ser adaptados e analisados com base em parâmetros do nosso sistema jurídico.

Em cumprimento à nossa proposta de abordagem do tema, não adotamos postura favorável ou contrária à utilização de medidas defensivas contra tomadas de controle hostis. Este posicionamento deve ser feito em relação a cada um dos casos concretos, conforme a conveniência e necessidade.

Sendo assim, concluímos este trabalho, acreditando ter fornecido, à comunidade jurídica e ao empresariado em geral, fundamentos para a decisão quanto à adoção de tais proteções em determinadas hipóteses, sempre analisando o tema do ponto de vista jurídico. 
XI. BIBLIOGRAFIA

ADAMEK, Marcelo Vieira von. Responsabilidade Civil dos Administradores de S/A (e as ações correlatas). São Paulo: Saraiva, 2009.

AKYOL, Ali C.; CARROLL, Carolyn A. Removing Poison Pills: a case of shareholder activism. Set. 2006. Disponível em SSRN: <http://ssrn.com/abstract=935950>. Acesso em: 12.12.2009.

ALLEN, William T.; KRAAKMAN, Reinier. Commentaries and Cases on the Law of Business Organization. Nova York: Aspen Publishers, 2003.

ALLEN, William T.; JACOBS, Jack B.; STRINE JR., Leo E. Function over Form: a reassessment of standards of review in Delaware Corporation Law. The Business Lawyer,

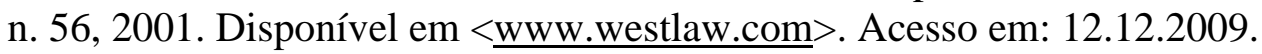

ALVES, José Carlos Moreira. Direito Romano. v.1, 3. ed. Rio de Janeiro: Forense, 1971.

AMIHUD, Yakov; LEV, Baruch. Risk Reduction as a Managerial Motive for Conglomerate Mergers. In: ROMANO, Roberta (coord.). Foundations of Corporate Law. 2. re-imp. Nova York: Foundation Press, 2004.

ARAGÃO, Paulo Cezar. Opções de compra de ações e bônus de subscrição. Revista dos Tribunais. São Paulo: RT, n. 631, pp. 63-70, maio. 1988.

ARMOUR, John; SKEEL, Jr., David A. Who writes the Rules for Hostile Takeover, and Why? - The Peculiar Divergence of US and UK Takeover Regulation. In: FERRARINI, Guido et al. (org.). Reforming Company and Takeover Law in Europe. Oxford: Oxford University Press, 2004. Também disponível em: European Corporate Governance Institute Working Paper Series in Law. n. 73, 2006. Disponível em $<$ http://papers.ssrn.com/sol3/papers.cfm?abstract_id=928928>. Acesso em: 12.12.2009.

The Divergence of U.S. and UK Takeover Regulation. Regulation. v. 30, n. 3, Inverno 2007. University of Pennsylvannia Institute for Law \& Economics Research Paper. n. 08-24. Disponível em SSRN: $<$ http://ssrn.com/abstract=1025986 $>$. Acesso em 12.12.2009.

ASCARELLI, Tullio. Problemi giuridici. Milão: Giuffré, 1959.

ATTUCH, Leonardo; GANOIS, Gustavo. O Plano da Vivendi no Brasil: Ele nem chegou e já está assustando os concorrentes. Isto É Dinheiro. São Paulo: Editora Três, n. 633, 25.11.2009, pp. 56-61.

AULETTA, Giuseppe; SALANITRO, Niccolò. Diritto Commerciale. 15. ed. Milão: Giuffrè, 2006. 
AZEVEDO, Antônio Junqueira de. Negócio jurídico: existência, validade e eficácia. São Paulo: Saraiva, 2002.

AZEVEDO, Luis André Negrelli de Moura. A oferta pública para aquisição de controle sob a perspectiva da companhia aberta ofertante. In: CASTRO, Rodrigo R. Monteiro; ARAGÃO, Leandro Santos de (coord.). Direito Societário: Desafios Atuais. São Paulo: Quartier Latin, 2009.

BAINBRIDGE, Stephen M. Unocal at 20: Director Primacy in Corporate Takeovers. Law \& Economics Research Papers Series. UCLA School of Law. Law-Econ Research Paper n. $\quad$ 05-19, set. $2005 . \quad$ Disponível em $<$ http://papers.ssrn.com/sol3/papers.cfm?abstract_id=796224> . Acesso em: 12.12.2009.

Director Primacy in Corporate Takeovers: Preliminary Reflections. Stanford Law Review, n. 54, nov. 2002. Disponível em SSRN: $<$ http://ssrn.com/abstract=330582 $>$. Acesso em: 12.12.2009.

BARNETT, Rachel J.; MICHELETTI, Edward B., WELCH, Edward P. Victory for Lyondell: Delaware Supreme Court reaffirms there is no single blueprint for following Revlon Duties. The M\&A Lawyer. v. 13, mai. 2009. Disponível em $<$ http://www.skadden.com/content/Publications/Publications1764_0.pdf $>$. Acesso em 12.12.2009.

BARROS, Guilherme de. Jornal Folha de São Paulo, 15.07.2008. Apud AZEVEDO, Luis André Negrelli de Moura. A oferta pública para aquisição de controle sob a perspectiva da companhia aberta ofertante. In: CASTRO, Rodrigo R. Monteiro de; ARAGÃO, Leandro Santos de (coord.). Direito Societário: Desafios Atuais. São Paulo: Quartier Latin, 2009.

BATALHA, Wilson de Souza Campos. Comentários à lei das Sociedades Anônimas. v. 2, Rio de Janeiro: Forense, 1977.

BAUMAN, Jeffrey D.; WEISS, Elliot J.; PALMITER, Alan R. Corporations - Law and Policy - Materials and Problems. 5. ed. Saint Paul: Thomson - West Group, 2003.

BEBCHUK, Lucian A.; COHEN, Alma. The Costs of Entrenched Boards. Journal of Financial Economics. v. 78, 2005; Harvard Law and Economics Discussion Paper, n. 478. Disponível em SSRN: <http://ssrn.com/abstract=556987>. Acesso em: 12.12.2009.

BEBCHUK, Lucian A.; COATES IV, John C.; SUBRAMANIAN, Guhan, The Powerful Antitakeover Force of Staggered Boards: Further Findings and a Reply to Symposium Participants. Stanford Law Review, v. 55, 2002; Harvard Law and Economics Discussion Paper, n. 393. Disponível em SSRN: <http://ssrn.com/abstract=360840>. Acesso em: 12.12.2009.

The Powerful Antitakeover Force of Staggered Boards: Theory, Evidence and Policy. NBER Working Paper, n. W8974, maio 2002. Disponível em: $<$ http://ssrn.com/abstract=314645 $>$. Acesso em: 12.12.2009. 
BEBCHUK, Lucian A. Why Firms Adopt Antitakeover Arrangements. University of Pennsylvania Law Review, n. 152, 2003; Harvard Law and Economics Discussion Paper,

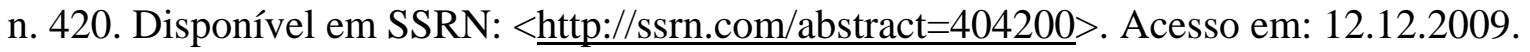

BEBCHUK, Lucian A. et al. On the Validity of Poison Pill By-Laws. jun. 2006. Disponível em SSRN: < http://ssrn.com/abstract=928674 > . Acesso em: 12.12.2009.

BELOCH, Henrique Vargas. CVM afasta Tag Along em Operações de Incorporação. Disponível em <http://www.bovespa.com.br/Investidor/Juridico/081128NotA.asp>. Acesso em: 12.12.2009.

BERLE, Adolf A.; MEANS, Gardiner C. The modern corporation and private property. 9. ed. New Brunswick / New Jersey: Transaction Publishers, 2007.

BESSONE, Darcy. Do contrato: teoria geral. São Paulo: Saraiva, 1997.

BLACK, Bernard. Strengthening Brazil's securities market. Revista de Direito Mercantil, Industrial, Econômico e Financeiro. São Paulo: Malheiros, n. 120, out./dez. 2000.

BM\&F-BOVESPA. Empresas Para Empresas: IPOs Recentes. Disponível em: $<$ http://www.bovespa.com.br/Empresas/InstInfoEmpresas/AberturaIPOsRecentes.asp?tit=2 7>. Acesso em: 12.12.2009.

BM\&F-BOVESPA. Empresas: Governança Corporativa. Perguntas frequentes. Disponível em <http://www.bovespa.com.br/empresas/novomercadoniveis/novomercadofaq.asp>. Acesso em: 12.12.2009.

BM\&F-Bovespa. Medidas para evitar concentração de controle estão presentes na maioria dos estatutos. 02.06.2008. Disponível em:

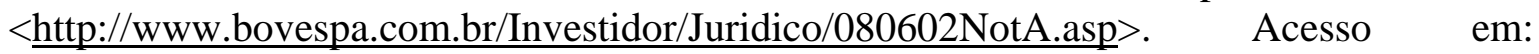
12.12.2009.

BOITEUX, Fernando Netto. Oferta pública de aquisição de controle de companhia aberta. Revista Forense. Rio de Janeiro: Forense, n. 301, jan./mar. 1988.

BOULTON, Thomas J. Maintaining Control: The Impact of Antitakeover Provisions on IPO Decisions. 12.06.2009. Disponível em SSRN: <http://ssrn.com/abstract=1418616>. Acesso em: 12.12.2009.

BULHÕES PEDREIRA, José Luiz. Alienação de Controle de Companhia Aberta. In LAMY FILHO, Alfredo; PEDREIRA, José Luiz Bulhões. A Lei das S.A. v. 2, 2. ed. Rio de Janeiro: Renovar, 1996.

Limite Estatutário do Direito de Voto. In LAMY FILHO, Alfredo; PEDEIRA, José Luiz Bulhões. A Lei das S.A. v. 2, 2. ed. Rio de Janeiro: Renovar, 1996. 
Parecer sobre controle e transferência de controle de empresas de telecomunicações. Proposta de regulamentação da ANATEL, relativo ao Projeto de "Regulamento de Apuração de Controle e Transferência de Controle em Empresas Prestadoras de Serviços de Telecomunicações”, submetido à consulta pública pela Anatel, 04.01.1999.

BURROUGH, Bryan e HELYAR, John. Barbarians At The Gate: the fall of RJR Nabisco. Nova York: Harper \& Row, 1990.

CÂMARA, Paulo. O dever de lançamento de oferta pública de aquisição no direito português. In: WARDE Jr., Walfrido Jorge (coord.). Fusão, Cisão, Incorporação e Temas Correlatos. São Paulo: Quartier Latin, 2009.

CAMPOS, Luiz Antonio de Sampaio. Conselho de Administração e Diretoria. In: LAMY FILHO, Alfredo; BULHÕES PEDREIRA, José Luiz. Direito das Companhias. v. 1, Rio de Janeiro: Forense, 2009.

CANTIDIANO, Luiz Leonardo. A aquisição do controle acionário da Cia. Mineira de Eletricidade: Um Caso Polêmico. In: Direito Societário \& Mercado de Capitais. Rio de Janeiro: Renovar, 1996.

Análise do caso Sadia X Perdigão: uma tentativa de "take over”. In: CASTRO, Rodrigo R. Monteiro de; ARAGÃO, Leandro Santos de (coord.). Sociedade Anônima: 30 anos da Lei 6.404/76, São Paulo: Quartier Latin, 2007.

Aquisição compulsória de ações. In: Reforma

da Lei das S.A. Rio de Janeiro: Renovar, 2002.

. Alienação e aquisição de controle. Revista da CVM. Rio de Janeiro: Comissão de Valores Mobiliários, v. 3, n. 9, p.35-42, set./out. 1985.

CARNEY, William J.; SILVERSTEIN, Leonard A. The Illusory Protections of the Poison Pill. 15.08.2002. Disponível em SSRN: <http://ssrn.com/abstract=323880>. Acesso em: 12.12.2009.

CARVAlHOSA, Modesto. As Poison Pills Estatutárias na Prática Brasileira: alguns aspectos de sua Legalidade. In: CASTRO, Rodrigo R. Monteiro; ARAGÃO, Leandro Santos de. Direito Societário: Desafios Atuais. São Paulo: Quartier Latin, 2009.

São Paulo: Saraiva, 1998.

Comentários à Lei de Sociedades Anônimas. v. 2, 2. ed.

Comentários à Lei de Sociedades Anônimas. v. 4, t. II, 2. ed. rev. e atual. São Paulo: Saraiva, 2003.

IBMEC, 1979.

Oferta pública de aquisição de ações. Rio de Janeiro: 
CASTELLO BRANCO, Adriano. O Conselho de Administração nas sociedades anônimas. 2. ed. Rio de Janeiro: Forense Universitária, 2007.

CHEFFINS, Brian R. Company Law: theory, structure and operation. Re-imp. 2006. Oxford: Oxford University Press, 1997.

CHEW, Don; JENSEN, Michael C. US Corporate Governance: Lessons from the 1980's. In JENSEN, Michael C. A Theory of the firm: governance, residual claims and organizational forms. Massachusetts: Harvard University Press, dez. 2000. Disponível em

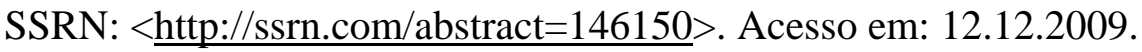

CHOPER, Jesse H.; COFFEE Jr., John C.; e GILSON, Ronald J. Cases and materials on corporations. 7. ed. Nova York: Aspen Publishers, 2008.

CLARK, Robert Charles. Corporate Law. Boston / Toronto: Little, Brown and Company, 1986.

COATES IV, John C. Explaining Variation in Takeover Defenses: blame the lawyers. California Law Review. v. 89, out. 2001. Disponível em SSRN: $<$ http://ssrn.com/abstract=304081 $>$. Acesso em: 12.12.2009.

Takeover Defenses in the Shadow of the Pill: a critique of the scientific evidence. Texas Law Review. v. 79, n. 2, dez. 2000. Disponível em SSRN: $<$ http://ssrn.com/abstract=263632 $>$. Acesso em: 12.12.2009.

. The Contestability of Corporate Control: a critique of the scientific evidence on takeover defenses. Harvard Law and Economics Discussion Paper, n. 265, set. 1999. Disponível em SSRN: <http://ssrn.com/abstract=173628>. Acesso em: 12.12.2009.

COMMENT, Robert; SCHWERT, G. William. Poison or Placebo? Evidence on the Deterrent and Wealth Effects of Modern Antitakeover Measures. Journal of Financial Economics. 1995. Disponível em SSRN: <http://ssrn.com/abstract=5781>. Acesso em: 12.12.2009.

COMPARATO, Fábio Konder. Aspectos Jurídicos da Macro-Empresa. São Paulo: RT, 1970.

Novas formas jurídicas de concentração empresarial. Revista de Direito Mercantil, Industrial, Econômico e Financeiro. São Paulo: Malheiros, n. 5, jan./mar. 1972.

Novos Ensaios e Pareceres de Direito Empresarial. Rio

de Janeiro: Forense, 1981.

COMPARATO, Fábio Konder; SALOMÃO FILHO, Calixto. O Poder de Controle na Sociedade Anônima. 4 ed. Rio de Janeiro: Forense, 2005. 
CORDEIRO, António Manuel da Rocha e Menezes. Da boa-fé no direito civil. v. 2. Coimbra: Almedina.

. Direito Europeu das Sociedades. Coimbra: Almedina,

2005.

. Manual de Direito das Sociedades: das sociedades em especial. v. 2, 2. ed. rev. e atual. Coimbra: Almedina, 2007.

. Ofertas Públicas de Aquisição. Revista da Ordem dos

Advogados. Lisboa, n. 56, 1996.

A $13^{\text {a }}$ Directriz do Direito das Sociedades (ofertas públicas de aquisição). Revista da Ordem dos Advogados. Lisboa, n. 64, 2004.

. A OPA Estatutária como Defesa contra Tomadas Hostis.

Revista da Ordem dos Advogados. Lisboa, n. 58, 1998.

Da Responsabilidade Civil dos Administradores das Sociedades Comerciais Lisboa: Lex, 1977.

- Da Tomada de Sociedades (Takeover): Efectivação, Valoração e Técnicas de Defesa. Revista da Ordem dos Advogados. Lisboa, n. 54, 1994.

CORREA, Cristiane; LETHBRIDGE, Tiago. Por que o negócio do ano não saiu? Revista Exame. 28.07.2006.

CORREIA, Luís Brito. Os administradores de Sociedades Anônimas. Coimbra: Almedina, 1993. Apud CAMPOS, Luiz Antonio de Sampaio. Conselho de Administração e Diretoria. In: LAMY FILHO, Alfredo; BULHÕES PEDREIRA, José Luiz. Direito das Companhias. v. 1, Rio de Janeiro: Forense, 2009.

COSTA, Carlos Celso Orcesi da. Controle externo nas companhias. Revista de Direito Mercantil, Industrial, Econômico e Financeiro. São Paulo: Malheiros, n. 144, out./dez. 1981.

CREMERS, Martijn; NAIR, Vinay B.; PEYER, Urs C. Takeover Defenses and Competition. Yale ICF Working Paper, n. 07-02; 2nd Annual Conference on Empirical Legal Studies Paper, abr. 2007. Disponível em SSRN: <http://ssrn.com/abstract=984064>. Acesso em: 12.12.2009.

DAVIES, Paul L. Shareholder Value: Company Law and Securities Markets Law - A British View. Out. 2000. Disponível em SSRN: <http://ssrn.com/abstract=250324>. Acesso em 12.12.2009.

DAVIES, Paul; HOPT, Klaus J. Control Transactions. In: KRAAKMAN, Reinier et al. The Anatomy of Corporate Law: A Comparative and Functional Approach. Oxford: Oxford University Press, 2004. 
DE PLÁCIDO E SILVA. Vocabulário Jurídico. 23. ed. Rio de Janeiro: Forense, 2003.

DINIZ, Maria Helena. Das disposições finais e transitórias. In AZEVEDO, Antônio Junqueira de. Comentários ao Código Civil. v. 22. São Paulo: Saraiva, 2003.

Dynamo Administração de Recursos Ltda. Carta Dynamo. n. 51, $3^{\circ}$ trim. 2006. Disponível em $<$ www.dynamo.com.br $>$. Acesso em: 12.12.2009.

EASTERBROOK, Frank H.; FISCHEL, Daniel R. The Proper Role of a Target's Management in Responding to a Tender Offer. In ROMANO, Roberta (coord.). Foundations of Corporate Law. 2. re-imp. Nova York: Foundation Press, 2004. Também disponível em: Harvard Law Review. v. 94, n. 6, pp. 1161-1204, abr. 1981.

The Economic Structure of Corporate Law. Paperback Edition, Massachusetts: Harvard University Press, 1996.

EDELMAN, Paul H.; Thomas, Randall S. The Value of Voting in Hostile Takeovers: an experimental model. Vanderbilt Law and Economics Research Paper, n. 02-11, 11.09.2002. Disponível em SSRN: <http://ssrn.com/abstract=336200>. Acesso em: 12.12.2009.

EISENBERG, Melvin Aron; CARY, William L. Corporations: Cases and Materials. 7. ed. Nova York: Foundation Press, 1995.

EIZIRIK, Nelson. O mito do “controle gerencial”: alguns dados empíricos. Revista de Direito Mercantil, Industrial, Econômico e Financeiro. São Paulo: Malheiros, n. 66, p.103106, abr./jun., 1987.

ESPÍNOLA, Eduardo. Garantia e extinção das obrigações. Atualizado por Francisco José Galvão Bruno. Campinas: Bookseller, 2005.

FERRARA Jr, Francesco; CORSI, Francesco. Gli Imprenditori e Le Società. 13. ed. Milão: Giuffrè, 2006.

FERRARINI, Guido et al. (org.). Reforming Company and Takeover Law in Europe. Oxford: Oxford University Press, 2004.

FERREL, Allen. Why Continental European Takeover Law Matters. In: FERRARINI, Guido et al. (org.). Reforming Company and Takeover Law in Europe. Oxford: Oxford University Press, 2004. Também disponível em: Harvard John M. Olin Center for Law, Economics and Business Discussion Paper, n. 454, 2003. Disponível em $<$ http://papers.ssrn.com/sol3/papers.cfm?abstract_id=500125 $>$. Acesso em: 12.12.2009.

FRAGA NETO, Armínio. O mercado de capitais como alavanca do desenvolvimento no Brasil. Revista de Direito Bancário e do Mercado de Capitais. São Paulo: RT, n. 41, p. 3941, jul./set. 2008. 
FRANÇA, Erasmo Valladão Azevedo e Novaes. Conflito de interesses nas assembléias de S.A. São Paulo: Malheiros, 1993.

. Invalidade das Deliberações de Assembléia das S.A. São

Paulo: Malheiros Editores, 1999.

Lineamentos da Reforma do Direito Societário Italiano em Matéria de Invalidade das Deliberações Assembleares. In: Temas de Direito Societário, Falimentar e Teoria da Empresa. São Paulo: Malheiros Editores, 2009.

Invalidade das deliberações sociais. Revista do Advogado. São Paulo: Associação dos Advogados de São Paulo, n. 57, jan. 2000.

FRANÇA, Erasmo Valladão Azevedo e Novaes; ADAMEK, Marcelo Vieira von. Affectio societatis: um conceito jurídico superado no moderno direito societário pelo conceito de fim social. In FRANÇA, Erasmo Valladão Azevedo e Novaes (coord.). Direito Societário Contemporâneo I. São Paulo: Quartier Latin, 2009.

FRANCO, Vera Helena de Mello. Considerações sobre as Ofertas Públicas para Aquisição de Ações (OPAs) - Estado Atual da Questão. Revista de Direito Mercantil, Industrial, Econômico e Financeiro. São Paulo: Malheiros, n. 144, out./dez. 2006.

GAGLIARDO, Mariano. Toma de Control Societario y Medidas Defensivas. Buenos Aires: Ad-Hoc, 1993.

GILSON, Ronald J. Seeking Competitive Bids Versus Pure Passivity in Tender Offer Defense. In: ROMANO, Roberta (coord.). Foundations of Corporate Law. 2. re-imp. Nova York: Foundation Press, 2004.

The Poison Pill in Japan: The Missing Infrastructure. European Corporate Governance Institute Working Paper Series in Law. n. 20, jan. 2004. Disponível em <http://papers.ssrn.com/sol3/papers.cfm?abstract_id=509522 >. Acesso em: 12.12.2009.

. Lipton and Rowe's Apologia for Delaware: A Short Reply. The Delaware Journal of Corporate Law. v. 27, n. 1, 2002. Disponível em SSRN: $<$ http://ssrn.com/abstract=398740 $>$. Acesso em: 12.12.2009.

GILSON, Ronald J.; KRAAKMAN, Reinier H. Takeovers in the Boardroom: Burke versus Schumpeter. Stanford Law and Economics Olin Working Paper, n. 306, mai. 2005; Columbia Law and Economics Working Paper, n. 280. Disponível em SSRN: $<$ http://ssrn.com/abstract=732783 $>$. Acesso em 12.12.2009.

GOERGEN, Marc; MARTYNOVA, Marina; RENNENBOOG, Luc. Corporate Governance Convergence: Evidence from takeover regulation. European Corporate Governance Institute Working Paper Series in Law. n. 33, abr. 2005. Disponível em

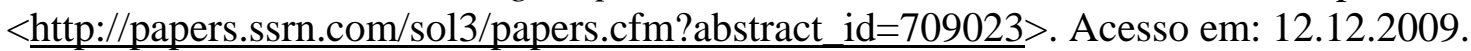


GOLDEN PARACHUTE. In: GARNER, Bryan A. Black's Law Dictionary. 4. ed. Saint Paul: West Group, 2001.

GOLDMAN, Eitan; SEVILIR, Merih. Large Shareholders and the Value of Takeover

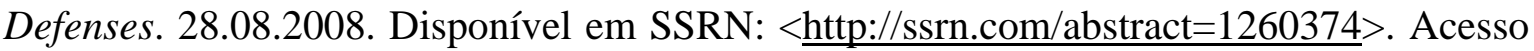
em: 12.12.2009.

GOMES, Orlando. Direitos Reais. 17. ed. Atualizada por Humberto Theodoro Júnior. Rio de Janeiro: Forense, 2000.

GORDON, Jeffrey N. An American Perspective on Anti-Takeover Laws in the EU: The German Example. In: FERRARINI, Guido et al. (org.). Reforming Company and Takeover Law in Europe. Oxford: Oxford University Press, 2004. Disponível em: $<$ http://ssrn.com/abstract=336420 $>$. Acesso em: 12.12.2009.

- An American Perspective on the New German Antitakeover Law. ECGI - Law Working Paper, n. 02, 2002; Columbia Law and Economics Working Paper, n. 209; Harvard Law and Economics Discussion Paper, n. 407. Disponível em SSRN: <http://ssrn.com/abstract=336420>. Acesso em: 12.12.2009.

Just Say Never? Poison Pills, Deadhand Pills, and Shareholder-Adopted Bylaws: An Essay for Warren Buffett. Cardozo Law Review. v. 19, n. 2, 1997. Disponível em SSRN: <http://ssrn.com/abstract=10564>. Acesso em: 12.12.2009.

GORGA, Erica. Changing the Paradigm of Stock Ownership: From Concentrated Towards Dispersed Ownership? Evidence from Brazil and Consequences for Emerging Countries. 3rd Annual Conference on Empirical Legal Studies Papers. Abr. 2008. Disponível em

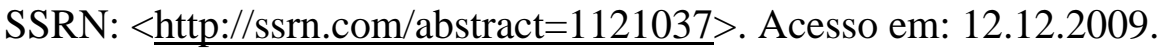

GREENMAIL. In: GARNER, Bryan A. Black's Law Dictionary. 4. ed. Saint Paul: West Group, 2001.

GUERREIRO, José Alexandre Tavares. Regime Jurídico do Capital Autorizado. São Paulo: Saraiva, 1984.

. Alienação de controle de companhia aberta: o papel das instituições financeiras. Revista de Direito Mercantil, Industrial, Econômico e Financeiro. São Paulo: Malheiros, n. 30, p. 115-119, abr./jun. 1978.

GUERREIRO, José Alexandre Tavares; TEIXEIRA, Egberto Lacerda. Sociedades anônimas no direito brasileiro. São Paulo: Bushatsky, 1979.

HANNES, Sharon. A Demand Side Theory of Anti-Takeover Defenses. Journal of Legal Studies. v. 35, 2006. Disponível em SSRN: <http://ssrn.com/abstract=926889 $>$. Acesso em: 12.12.2009. 
The Hidden Virtue of Antitakeover Defenses. Harvard Law School John M. Olin Center for Law, Economics and Business Discussion Paper Series. $\quad$ n. 354, 2002. $\quad$ Disponível em $<$ http://www.law.harvard.edu/programs/olin_center/corporate_governance/papers/No354.0 .Hannes.pdf $>$. Acesso em: 12.12.2009.

. The Market for Takeover Defenses. Northwestern University Law Review. v. 101, 2007. Disponível em SSRN:

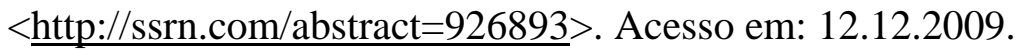

HANSMANN, Henry e KRAAKMAN, Reinier R. Agency Problems and legal Strategies. In The Anatomy of Corporate Law - A Comparative and Functional Approach. Oxford: Oxford University Press, 2004.

. The End of History for Corporate Law. Harvard Law School John M. Olin Center for Law, Economics, and Business Discussion Paper Series, n. 280, 2000. Disponível em <http://papers.ssrn.com/sol3/papers.cfm?abstract id=204528>. Acesso em: 12.12.2009.

What is Corporate Law?. In The Anatomy of Corporate Law - A Comparative and Functional Approach. Oxford: Oxford University Press, 2004.

HERON, Randall A.; LIE, Erik. On the Use of Poison Pills and Defensive Payouts by Takeover Targets. Journal of Business, Forthcoming. 2005. Disponível em SSRN: $<$ http://ssrn.com/abstract=647637> . Acesso em: 12.12.2009.

HERTIG, Gérard.; McCAHERY, Joseph A. An Agenda for Reform. In: FERRARINI, Guido et al. (org.). Reforming Company and Takeover Law in Europe. Oxford: Oxford University Press, 2004.

HIRIGOYEN, Gérard. Brief History of the B.S.N.: Saint-Gobain Takeover Attempt. dez. 1968 / jan. 1969. Disponível em <http://ssrn.com/abstract=144768>. Acesso em: 12.12.2009.

HOPT, Klaus J. Deveres legais e conduta ética de membros do conselho de administração e de profissionais. Tradução de Erasmo Valladão A. e N. França e Mauro Moisés Kertzer. Revista de Direito Mercantil, Industrial, Econômico e Financeiro. São Paulo: Malheiros, n. 144, p. 107-119, out./dez. 2006.

JACKSON, Gregory; HÖPNER, Martin. An Emerging Market for Corporate Control? The Mannesmann Takeover and German Corporate Governance. Max-Planck-Institute for the Study of Societies Discussion Paper. n. 01/4, set. 2001. Disponível em: $<$ http://ssrn.com/abstract=285232 $>$. Acesso em 12.12.2009.

JAGANNATHAN, Murali; PRITCHARD, Adam C. Does Delaware Entrench Management?. University of Michigan Law \& Economics, Olin Working Paper, n. 08-024, 08.12.2008. Disponível em SSRN: <http://ssrn.com/abstract=1313274>. Acesso em: 12.12.2009. 
JARREL, Gregg A.; BRICKLEY, James A.; NETTER, Jeffry M. The Market for Corporate Control: The Empirical Evidence Since 1980. In ROMANO, Roberta (coord.). Foundations of Corporate Law. 2. re-imp. Nova York: Foundation Press, 2004.

JENSEN, Michael C. Takeovers: their causes and consequences. Journal of Economic Perspectives. v. 2, n. 1, 1988. Disponível em SSRN: <http://ssrn.com/abstract=173455>. Acesso em: 12.12.2009.

JENSEN, Michael C.; MECKLING, W. Theory of the Firm: Managerial Behavior. Agency Cost, and Ownership Structure. Journal of Financial Economics. v. 3, n. 4, 1976.

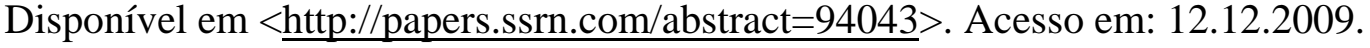

JENSEN, Michael C.; RUBACK, Richard S. The Market for Corporate Control: The Scientific Evidence. In ROMANO, Roberta (coord.). Foundations of Corporate Law. 2. reimp. Nova York: Foundation Press, 2004.

JUNQUEIRA, Antonio; SEQUEIRA, Carlos. Poison pills don’t increase a stock value. Getting to know Brazil. BTG Pactual, 23.11.2009.

JUSTEN FILHO, Marçal. Comentários à lei de licitações e contratos administrativos. São Paulo: Dialética, 2009.

KARPOFF, Jonathan M.; DANIELSON, Morris G., Do Pills Poison Operating Performance?. 07.05.2002. Disponível em SSRN: <http://ssrn.com/abstract=304647>. Acesso em: 12.12.2009.

KINI, Omesh; KRACAW, William; MIAN, Shehzad L. Corporate Takeovers, Firm Performance, and Board Composition. Jul. 1994. Disponível em SSRN: $<$ http://ssrn.com/abstract=5527>. Acesso em: 12.12.2009.

KRAAKMAN, Reinier et al. The Anatomy of Corporate Law: A Comparative and Functional Approach. Oxford: Oxford University Press, 2004.

LAIDE, John. Research Spotlight: Poison Pill M\&A Premiums. Nova York, 30.08.2005. Disponível em <http://www.sharkrepellent.net/pub/rs_20050830.html $>$. Acesso em: 12.12.2009.

LAMY FILHO, Alfredo; BULHÕES PEDREIRA, José Luiz. A Lei das S.A. v. 1, Rio de Janeiro: Renovar, 1992.

A Lei das S.A. v. 2, 2. ed. Rio de Janeiro: Renovar, 1996.

Direito das Companhias. v. 1, Rio de Janeiro: Forense,

2009.

Direito das Companhias. v. 2, Rio de Janeiro: Forense,

2009. 
LAZZARESCHI NETO, Alfredo Sérgio. Lei das Sociedades por Ações Anotada. 2. ed. rev. ampl. e atual. São Paulo: Saraiva, 2008.

LEÃES, Luiz Gastão Paes de Barros. Conflito de interesses e vedação de voto nas assembléias das sociedades anônimas. Revista de Direito Mercantil, Industrial, Econômico e Financeiro. São Paulo: Malheiros, n. 92, out./dez, 1993.

. Incorporação de ações de companhia aberta controlada. In: . Pareceres. v. 2, São Paulo: Singular, 2004.

LEITÃO, Luís Manuel Teles de Menezes. As medidas defensivas contra uma oferta pública de aquisição hostil. In O Direito. Ano 138, t. III, Coimbra: Almedina, 2006.

LIMA, Osmar Brina Correa. Responsabilidade civil dos administradores de sociedades anônimas. Rio de Janeiro: Aide, 1989.

LIPTON, Martin; STEIBERGER, Erica H. Takeovres \& Freezeouts. v. 1A, Nova York: Law Journal Press, 2003.

LIPTON, Martin; ROWE, Paul K. Pills, Polls and Professors: A Reply to Professor Gilson. New York University Center for Law and Business Research Paper, n. 01-006, abr. 2001. Disponível em SSRN: <http://ssrn.com/abstract=268520>. Acesso em 12.12.2009. Também disponível em: The Delaware Journal of Corporate Law. v. 27, n. 1, pp. 1-55, 2002. Disponível em SSRN: < http://ssrn.com/abstract=398060>. Acesso em 12.12.2009.

LOBO, Carlos Augusto da Silveira. Sociedades coligadas, controladoras e controladas. In: LAMY FILHO, Alfredo; BULHÕES PEDREIRA, José Luiz. Direito das Companhias. v. 2, Rio de Janeiro: Forense, 2009.

LOPEZ, Ernesto Adolfo Hernandez. Bag Wars and Bank Wars, the Gucci and Banque National de Paris Hostile Bids: European Corporate Culture Responds to Active Shareholders. Fordham Journal of Corporate \& Financial Law. v. 9, n. 1, 2003.

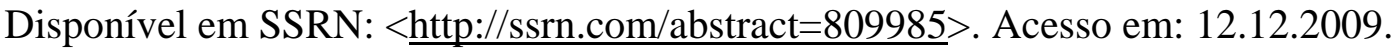

LUQUET, Mara. Caso Sadia-Perdigão é sinal de evolução do mercado. Jornal Valor Econômico, 24.07.2006.

MACEDO, Ricardo Ferreira de. Controle Não Societário. Rio de Janeiro: Renovar, 2004.

Limites de efetividade do direito societário na repressão ao uso disfuncional do poder de controle nas sociedades anônimas. Revista de Direito Mercantil, Industrial, Econômico e Financeiro. São Paulo: Malheiros, n. 120, out./dez. 2000.

MACINTOSH, Jeffrey G. Poison Pills in Canada: a reply to dey and yalden. Canadian Business Law Journal. v. 17, 1991. Disponível em SSRN: $<$ http://ssrn.com/abstract=1156939 $>$. Acesso em: 12.12.2009. 
MAGALHÃES, Roberto Barcellos de. A Nova Lei das Sociedades por Ações Comentada. v. 2, São Paulo: Freitas Bastos, 1977.

MALATESTA, Paul H.; WALKLING, Ralph A. Poison Pill Securities: Stockholder Wealth, Profitability, and Ownership Structure. Journal of Financial Economics. v. 20, 1989. Disponível em SSRN: <http://ssrn.com/abstract=918047> . Acesso em: 12.12.2009.

MANNE, Henry G. Theories and Evidence. Mergers and the Market for Corporate Control. In ROMANO, Roberta (coord.). Foundations of Corporate Law. 2. re-imp. Nova York: Foundation Press, 2004.

MARQUETTE, Christopher J.; BIZJAK, John M. Shareholder Proposals to Rescind Poison Pills: All Bark and No Bite?. 01.03.1996. Disponível em SSRN: $<$ http://ssrn.com/abstract=1352 $>$. Acesso em: 12.12.2009.

The Impact of Poison Pill Adoption on Managerial Compensation. 01.02.1999. Disponível em SSRN: <http://ssrn.com/abstract=148396>. Acesso em: 12.12.2009.

MARTINEZ, Pedro Romano; PONTE; Pedro Fuzeta da. Garantias gerais de cumprimento. 4. ed. Coimbra: Almedina, 2003.

MARTINS, Alexandre Soveral. Valores Mobiliários (Acções). Coimbra: Almedina, 2003.

MARTINS, Fran. Comentários à Lei das S.A.. v. 3, 2. ed. rev. e aumentada. Rio de Janeiro: Forense, 1985.

MARTINS, Ives Gandra da Silva; VIDIGAL, Geraldo de Camargo (coord.). Comentários à Lei das Sociedades por Ações. Rio de Janeiro: Forense Universitária, 1999.

MARTINS-COSTA, Judith. A boa-fé no direito privado. São Paulo: Revista dos Tribunais, 1999.

MERLE, Philippe, Droit commercial: sociétés commerciales. 10. ed. Paris: Dalloz, 2005.

MITCHELL, Mark L.; MULHERIN, J. Harold. The Impact of Industry Shocks on Takeover and Restructuring Activity. Journal of Financial Economics. v. 41, 1996. Disponível em $<$ http://www.sciencedirect.com/science?_ob=ArticleListURL\&_method=list\&_ArticleList

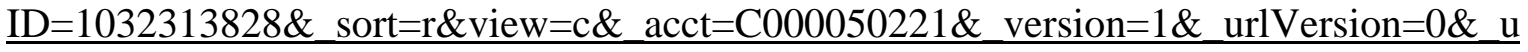
serid=10\&md5=56f4cf4181a2b86b4b599db9fe2e3fd5 $>$. Acesso em: 12.12.2009.

MONTEIRO, Washington de Barros. Curso de Direito Civil: parte geral. v. 1, 41. ed. São Paulo: Saraiva, 2007. 
MOORE, Andrew G.T. The Birth of Unocal: A Brief History. Delaware Journal of Coporate Law. v. 31, n. 3, 2006. Disponível em: <http://ssrn.com/abstract=946018>. Acesso em: 12.12.2009.

MORAES, Luiza Rangel de. A Pulverização do Controle de Companhias Abertas. Revista de Direito Bancário e do Mercado de Capitais. São Paulo: RT, n. 32, p. 49-84, abr./jun. 2006.

MORSE, Geoffrey. Charlesworth's Company Law. 17. ed. Londres: Sweet \& Maxwell, 2005.

MUCCIARELLI, Federico M. White Knights and Black Knights: Does the Search for Competitive Bids Always Benefit the Shareholders of 'Target' Companies?. 15.06.2006. Disponível em SSRN: <http://ssrn.com/abstract=910220>. Acesso em 12.12.2009.

MUELLER, Holger M.; PANUNZI, Fausto. Tender Offers and Leverage. New York University Working Paper, n. FIN-03-018. Disponível em SSRN: $<$ http://ssrn.com/abstract=1298843 $>$. Acesso em 12.12.2009.

MÜSSNICH, Francisco Antunes Maciel. A utilização desleal de informações privilegiadas - "Insider Trading” - no Brasil e nos Estados Unidos. Revista de Direito Mercantil, Industrial, Econômico e Financeiro. São Paulo: Malheiros, n. 34, pp. 31-51, abr./jun. 1979.

MÜSSNICH, Francisco Antunes Maciel; PERES, Fábio Henrique. Administração deve colaborar para o melhor uso das poison pills. Disponível em $<$ http://www.bmalaw.com.br/nova_internet/arquivos/Artigos/Numero\%2025.pdf $>$. Acesso em: 12.12.2009.

MUNHOZ, Eduardo Secchi. Desafios do direito societário brasileiro na disciplina da companhia aberta: avaliação dos sistemas de controle diluído e concentrado. In CASTRO, Rodrigo R. Monteiro; ARAGÃO, Leandro Santos de (coord.). Direito Societário: Desafios Atuais. São Paulo: Quartier Latin, 2009.

Empresa contemporânea e Direito Societário: Poder de Controle e Grupos de Sociedade. São Paulo: Juarez de Oliveira, 2002.

NASCIMENTO, João Pedro Barroso do. Conflito de interesses no exercício do direito de voto nas sociedades anônimas ( $1^{\mathrm{a}}$ parte). Revista de Direito Bancário e do Mercado de Capitais. São Paulo: RT, n. 24, abr. /jun. 2004.

Conflito de interesses no exercício do direito de voto nas sociedades anônimas ( $2^{\mathrm{a}}$ parte). Revista de Direito Bancário e do Mercado de Capitais. São Paulo: RT, n. 25, jul./set. 2004.

NASCIMENTO, João Pedro Barroso do; VAZ, Ernesto Luís Silva. Poderes da Administração na oferta hostil de aquisição de controle no direito comparado (medidas defensivas e poison pills). In FRANÇA, Erasmo Valladão Azevedo e Novaes (coord.). Direito Societário Contemporâneo I. São Paulo: Quartier Latin, 2009. 
NERY JUNIOR, Nelson; NERY, Rosa Maria de Andrade. Código Civil anotado $e$ legislação extravagante. 2. ed. São Paulo: RT, 2003.

NUNES, Pedro Caetano. Responsabilidade civil dos administradores perante os accionistas. Coimbra: Almedina, 2001.

ODRIOZOLA, Juan Martín. Compraventa Accionaria y Take over: la función profesional. In Negocios Parasocietarios. Buenos Aires: Ad-Hoc, 1994.

OIOLI, Erik Frederico. Oferta Pública de Aquisição de Controle de Companhias Abertas. 2008. Dissertação (Mestrado em Direito Comercial sob orientação do Professor Doutor Erasmo Valladão Azevedo e Novaes França) - Faculdade de Direito, Universidade de São Paulo, São Paulo, 2008.

OSÓRIO, José Diogo Horta. Da Tomada do Controlo de Sociedades (takeovers) por Leveraged Buy-Out e sua Harmonização com o Direito Português. Coimbra: Almedina, 2001.

PAC-MAN DEFENSE. In: GARNER, Bryan A. Black's Law Dictionary. 4. ed. Saint Paul: West Group, 2001.

PARRILLI, Davide Maria. The Defensive Measures in Case of Takeover Bids: The Italian Perspective. 22.06.2006. Disponível em SSRN: <http://ssrn.com/abstract=1270562>. Acesso em: 12.12.2009.

PASTERIS, Carlo. Il controllo. Milão: Giuffrè, 1957. Apud PEREIRA, Guilherme Döring Cunha. Alienação do Poder de Controle Acionário. São Paulo: Saraiva, 1995.

PENTEADO, Mauro Rodrigues. Apontamentos sobre a Alienação do Controle de Companhias Abertas. Revista de Direito Mercantil, Industrial, Econômico e Financeiro. São Paulo: Malheiros, n. 76, p. 15-25, out./dez. 1989.

Paulo: Saraiva, 1988. Aumento de Capital das Sociedades Anônimas. São - Nota Bibliográfica ao livro Empresa Contemporânea e Direito Societário. Poder de Controle e Grupos de Sociedades, de Eduardo Secchi Munhoz. Revista de Direito Mercantil, Industrial, Econômico e Financeiro. São Paulo: Malheiros, n. 133, pp. 301-302, jan./mar. 2004.

Sociedade Anônima: acionista controlador. Revista de Direito Mercantil, Industrial, Econômico e Financeiro. São Paulo: Malheiros, n. 83, p. 99115, jul./set. 1991.

PEREIRA, Guilherme Döring Cunha. Alienação do Poder de Controle Acionário. São Paulo: Saraiva, 1995. 
PEREIRA, Jorge Brito. A OPA Obrigatória. Coimbra: Almedina,1998.

PINTO, Carlos Alberto da Mota. Teoria Geral do Direito Civil. 4. ed. Atualizada por António Pinto Monteiro e Paulo Mota Pinto. Coimbra: Coimbra Editora, 2005.

POISON PILL. In: GARNER, Bryan A. Black’s Law Dictionary. 4. ed. Saint Paul: West Group, 2001.

PONTES DE MIRANDA, Francisco Cavalcanti. Tratado de Direito Privado. t. V, Campinas: Bookseller, 2000.

PORCUPINE PROVISION. In: GARNER, Bryan A. Black's Law Dictionary. 4. ed. Saint Paul: West Group, 2001.

PRADO, Roberta Nioac. Oferta Pública de Ações Obrigatória nas S.A.: Tag Along. São Paulo: Quartier Latin, 2005.

RAYNA, Thierry; STRIUKOVA, Ludmila. White Knight or Trojan Horse? The Consequences of Digital Rights Management for Consumers, Firms and Society. Communications \& Strategies. n 69, 04.03.2009. Disponível em SSRN: $<$ http://ssrn.com/abstract=1353075 $>$. Acesso em: 12.12.2009.

REQUIÃO, Rubens. Curso de direito comercial. v. 2, 20. ed. São Paulo: Saraiva, 1995.

O Controle e a Proteção dos Acionistas. Revista de Direito Mercantil, Industrial, Econômico e Financeiro. São Paulo: Malheiros, n. 15/16, p. 23-35, out./dez. 1974.

REVISTA CAPITAL ABERTO. As melhores companhias para os acionistas. Dez. 2006.

RIBEIRO, Joaquim de Sousa. A boa-fé como norma de validade. In: Direito dos contratos: estudos. Coimbra: Coimbra Editora, 2007.

RIBEIRO, Renato Ventura. Dever de Diligência dos administradores de sociedades. São Paulo: Quartier Latin, 2006.

ROMANO, Roberta (coord.). Foundations of Corporate Law. 2. re-imp. Nova York: Foundation Press, 2004.

SALOMÃO FILHO, Calixto. O Novo Direito Societário. 3. ed. São Paulo: Malheiros, 2006.

SANTANA, Maria Helena dos Santos Fernandes de; GUIMARÃES, Juliana Paiva. Mercado de valores mobiliários: evolução recente e tendências. Revista de Direito Bancário e do Mercado de Capitais. São Paulo: RT, n. 41, p. 56-64, jul./set. 2008.

SCORCHED-EARTH DEFENSE. In: GARNER, Bryan A. Black's Law Dictionary. 4. ed. Saint Paul: West Group, 2001. 
SHARK REPELLENT. In: GARNER, Bryan A. Black's Law Dictionary. 4. ed. Saint Paul: West Group, 2001.

SHIMEGATSU, Plínio José Lopes. Mecanismos de proteção e estratégias de defesa em tomadas hostis de controle. In CASTRO, Rodrigo R. Monteiro; ARAGÃO, Leandro Santos de. Direito Societário: Desafios Atuais. São Paulo: Quartier Latin.

SILVA, Alexandre Couto. Responsabilidade dos Administradores de S/A: Business Judgment Rule. Rio de Janeiro: Elsevier, 2007.

SILVEIRA, Alexandre Di Miceli da. Corporate Governance Myths in Brazil: an analysis of common statements made by market practitioners. 08.12.2008. Disponível em SSRN: $<$ http://ssrn.com/abstract=1313206 $>$. Acesso em: 12.12.2009.

SOUZA, Ernani Vieira de. Obrigação. In Enciclopédia Saraiva do Direito. v. 55, São Paulo: Saraiva, 1977.

SRINIDHI, Bin; SEN, Kaustav. Effect of Poison Pills on Value Relevance of Earnings. fev. 2002. Disponível em SSRN: <http://ssrn.com/abstract=302646>. Acesso em: 12.12.2009.

STOUT, Lynn A. Takeovers in the Ivory Tower: How Academics are Learning Martin Lipton May be Right. UCLA School of Law, Law-Econ Research Paper, n. 05-21, set. 2005. Disponível em SSRN: < http://ssrn.com/abstract=803836>. Acesso em 12.12.2009.

SUBRAMANIAN, Guhan. Bargaining in the Shadow of Takeover Defenses. Yale Law Journal. v. 113, n. 3, dez. 2003. Disponível em SSRN: <http://ssrn.com/abstract=442721>. Acesso em: 12.12.2009.

The Disappearing Delaware Effect. Harvard Law and Economics Discussion Paper, n. 391, out. 2002. Disponível em SSRN: $<$ http://ssrn.com/abstract $=345040>$. Acesso em 12.12.2009.

TAMBURRINI, Giovanni. Harmonization of Takeover Discipline: A Comparative Law and Economic Overview. 22.06.2009. Disponível em SSRN: $<$ http://ssrn.com/abstract=1423762 $>$. Acesso em: 12.12.2009.

TEIXEIRA, Egberto Lacerda; GUERREIRO, José Alexandre Tavares. Das sociedades anônimas no direito brasileiro. v. 2, São Paulo: José Bushatsky, 1979.

TEPEDINO, Gustavo; SCHREIBER, Anderson. Os efeitos da Constituição em relação à cláusula geral da boa-fé no Código de Defesa do Consumidor e no Código Civil. Revista da EMERJ. Rio de Janeiro: EMERJ, v. 6, n. 23, 2003.

TEPEDINO, Ricardo. Assembléia Geral. In: LAMY FILHO, Alfredo; PEDREIRA, José Luiz Bulhões. Direito das Companhias. v. 1. Rio de Janeiro: Forense, 2009. 
TESTA, Pedro. The Mandatory Bid Rule in the European Community and in Brazil: A Critical View. Ago. 2006. Disponível em SSRN: <http://ssrn.com/abstract=943089>. Acesso em: 12.12.2009.

TOLEDO, Paulo Fernando Campos Salles de. O Conselho de Administração na Sociedade Anônima: estrutura, funções e poderes, responsabilidade dos administradores, 2. ed. São Paulo: Atlas, 1999.

Poison pill: modismo ou solução?. In CASTRO, Rodrigo R. Monteiro; ARAGÃO, Leandro Santos de (coord.). Direito Societário: Desafios Atuais. São Paulo: Quartier Latin, 2009.

TOMASETTI JR., Alcides. Oferta contratual em mensagem publicitária - regime do direito comum e do Código de Proteção do Consumidor. Revista de Direito do Consumidor. São Paulo: RT, n. 4, p. 241-254, out./dez. 1992.

VALADARES, Silvia Mourthé; LEAL, Ricardo Pereira Câmara. Ownership and Control Structure of Brazilian Companies. 2000. Disponível em SSRN: $<$ http://ssrn.com/abstract=213409 $>$. Acesso em: 12.12.2009.

VALENTI, Graziella; FREGONI, Silvia. A Caminho da Pulverização. Jornal Valor Econômico, 19.06.2009, p. D1.

VELASCO, Julian, Just Do It: An Antidote to the Poison Pill. Emory Law Journal. v. 52, 2003. Disponível em SSRN: < http://ssrn.com/abstract=324882> . Acesso em: 12.12.2009.

The Enduring Illegitimacy of the Poison Pill. The Journal of Corporation Law. v. 27, n. 3, pp. 381-423, primavera 2002. Disponível em

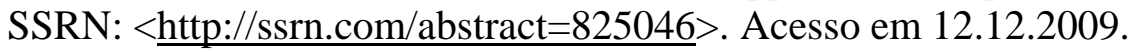

VENTORUZZO, Marco. Takeover Regulation as a Wolf in Sheep's Clothing: Taking Armour \& Skeel's Thesis to Continental Europe Bocconi Legal Studies Research Paper, n.

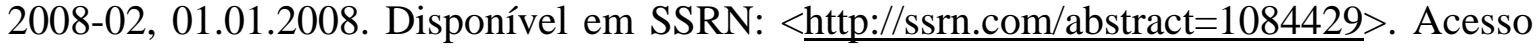
em: 12.12.2009.

European and U.S. Takeover Regulation: Different (Regulatory) Means, Not so Different (Political and Economic) Ends?. Bocconi Legal Studies Research Paper, n. 06-07, 04.10.2005. Disponível em SSRN: <http://ssrn.com/abstract=819764>. Acesso em: 12.12.2009.

VOLPIN, Paolo F.; PAGANO, Marco. Managers, Workers, and Corporate Control. EFA 2002 Berlin Meetings Presented Paper; ECGI - Finance Working Paper, n. 1, ago. 2002. Disponível em SSRN: <http://ssrn.com/abstract=299923 $>$. Acesso em: 12.12.2009.

WALD, Arnoldo. O governo das empresas. Revista de Direito Bancário e do Mercado de Capitais. São Paulo: RT, n. 15, jan./abr. 2002. 
WARNER, Jerold B.; JENSEN, Michael C. The Distribution of Power Among Corporate Managers, Shareholders, and Directors. In JENSEN, Michael C. A Theory of The Firm: governance, residual claims and organizational forms. Massachusetts: Harvard University Press, dezembro 2000. Disponível em SSRN: <http://ssrn.com/abstract=173459 >. Acesso em: 12.12.2009.

WHITE KNIGHT. In: GARNER, Bryan A. Black's Law Dictionary. 4. ed. Saint Paul: West Group, 2001.

WINTER, Jaap W. et al. Report of the High Level Group of Company Law Experts on Issues Related to Takeover Bids in the European Union. Jan. 2002. Disponível em SSRN:

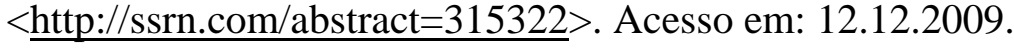

\section{Decisões administrativas nacionais}

CVM, Memorando 058/2001, Superintendência de Registro de Valores Mobiliários - SRE, Rel. Dir. Luiz Antonio de Sampaio Campos, 17.07.2001.

CVM, Memorando 1004/2006, Procuradoria Federal Especializada - PFE, 31.08.2006.

CVM, Memorando 214/2008, Superintendência de Registro de Valores Mobiliários - SRE, Gerência de Registros 1 - GER-1, 19.09.2008.

CVM, Memorando, Dir. Marcos Barbosa Pinto e Dir. Otávio Yazbek, 14.04.2008. Disponível em: <http://www.cvm.gov.br/port/infos/6491-0.asp>. Acesso em: 12.12.2009

CVM, Processo Administrativo RJ-2006-6209, Rel. Dir. Wladimir Castelo Branco Castro, j. 25.09.2006.

CVM, Processo Administrativo RJ-2007-14099, Rel. Dir. Durval Soledade, j. 29.01.2007.

CVM, Processo Administrativo RJ-2008-4156, Rel. Dir. Sergio Weguelin, j. 17.06.2008.

CVM, Processo Administrativo RJ-2008-7849.

CVM, Processo Administrativo RJ-2009-5811, Rel. Superintendência de Relações com Empresas - SEP, j. 28.07.2009.

CVM, Processo Administrativo Sancionador RJ-2005-1443, Rel. Dir. Pedro Oliva Marcilio de Sousa, j. 21.03.2006.

CVM, Relatório de Análise da Audiência Pública n. 03/09.

\section{Decisões judiciais nacionais}


TJMG, 17ª CC, AI 1.0414.08.024224-4/001(1), Rel. Des. Lucas Pereira, j. 04.06.2009, v.m.

TJSP, $25^{\text {a }}$ Câm. $3^{\circ}$ Grupo - Extinto $2^{\circ}$ TAC, AI 1076336000, Rel. Des. Ricardo Pessoa de Mello Belli, j. 10.10.2006, v.u.

TJSP, $9^{a}$ CC, AC 281.2 99-4/9-00, Rel. Des. Grava Brazil, j. 12.08.2008, v.m.

\section{Decisões judiciais estrangeiras}

Cheff v. Mathes (199 A.2d 548, Delaware, 1964, Rel. James B. Carey).

CTS Corp. v. Dynamics Corp. of America (481 US 69, Suprema Corte dos Estados Unidos, 1987, Rel. Lewis Powell).

Edgard v. MITE Corp. (457 US 624, Suprema Corte dos Estados Unidos, 1982, Rel. Byron R. White).

Garlock Inc. v. Colt Industries Inc., Complaint, 75 Civ. 5831 (SDNY, nov. 19, 1975).

General Host Corp. v. Triumph American Inc. (359 F. Supp. 749, Corte Federal de Distrito de Nova York - SDNY, 1973).

Great Western United Corp. v. Great Western Producers Co-Op. (613 P.2d 873, Colorado, 1980, Rel. Luis D. Rovira).

In re Santa Fe Pac. Corp. Shareholder Litigation (669 A.2d 59, Delaware, 1995, Rel. E. Normal Veasey).

In re Walt Disney Co. Deriv. Litigation (906 A 2.d 27, Delaware, Rel. William B. Chandler)

Ivanhoe Partners v. Newmont Mining Corp. (535 A.2d 1334, Delaware, 1987).

Jewel Companies, Inc v. Pay Less Drug Stores Norhwest, Inc. (741 F.2d 1555, Corte Federal de Apelação do $9^{\circ}$ Circuito, 1984, Rel. Stephen Roy Reinhardt).

Mills Acquisition Co. v. Macmillan, Inc. (559 A.2d 1261, Delaware, 1989, Rel. Andrew G. T. Moore).

Moran v. Household International, Inc. (500 A.2.d 1346, Delaware, 1985, Rel. John J. McNeilly).

Panter v. Marshall Field \& Co Weiss (646 F.2d 271, Corte de Apelação do $7^{\circ}$ Circuito, 1981, Rel. Wilbur Frank Pell Jr.). 
Paramount Communications, Inc. \& KDS Acquisitions Corp. v. Time, Inc. et al. (571 A.2d 1140, Delaware, 1989, Rel. Henry R. Horsey).

Paramount Communications, Inc. v. QVC Network, Inc. (637 A.2d 34, Delaware, 1994, Rel. E. Normal Veasey).

Revlon v. MacAndrews and Forbes Holdings, Inc. (506. A.2d 173, Delaware, 1986, Rel. Andrew G. T. Moore).

Schnell v. Chris-Craft Industries, Inc. (285 A.2d 437, Delaware, 1971, Rel. Daniel L. Herrmann).

Smith v. Van Gorkom (488 A.2d 858, Delaware, 1985, Rel. Henry R. Horsey).

Unitrin, Inc. v. American General Corp. (651 A.2d 1361, Delaware, 1995, Rel. Randy J. Holland).

Unocal v. Mesa Petroleum (493 A.2d 946, Delaware, 1985, Rel. Andrew G. T. Moore).

Walter E. Ryan, Jr. v. Lyondell Chemical Company, et al (C.A. n. 3176-VCN, Delaware, 2008, Rel. John W. Noble). 